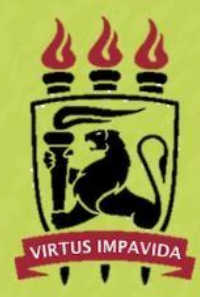

MSEU

PRODEMA

\title{
SABERES AMBIENTAIS: \\ REFLEXÕES SOBRE A RELAÇÃO \\ SOCIEDADE-NATUREZA
}

ORGANIZADORES:

ANTÔNIO HÉlton Vasconcelos dos Santos Manuela Maria Pereira do Nascimento

itactuacaiúnas 
Antônio Hélton Vasconcelos dos Santos

Manuela Maria Pereira do Nascimento

Bruno Augusto Nogueira Monteiro Pontes

Organizadores

\section{SABERES AMBIENTAIS: REFLEXÕES SOBRE A RELAÇÃO SOCIEDADE-NATUREZA}


(C) 2020 por Antônio Hélton Santos, Manuela do Nascimento e Bruno Pontes

(C) 2020 por vários autores

Todos os direitos reservados.

Conselho editorial

Colaboradores:

Márcia Aparecida da Silva Pimentel

Universidade Federal do Pará - UFPA

José Antônio Herrera

Universidade Federal do Pará - UFPA

Wildoberto Batista Gurgel

Universidade Federal Rural do Semi-Árido - UFERSA

André Luiz de Oliveira Brum

Universidade Federal do Rondônia - UNIR

Mário Silva Uacane

Universidade Licungo / Moçambique

Francisco da Silva Costa

Universidade do Minho / Portugal

Ofelia Pérez Montero

Universidad de Oriente- Santiago de Cuba-Cuba

Editora-chefe

Viviane Corrêa Santos

(Universidade do Estado do Pará - UEPA)

Preparação e organização dos originais: Walter Rodrigues

Capa e projeto gráfico: Dos Organizadores

Dados Internacionais de Catalogação na Publicação (CIP) de acordo com ISBD

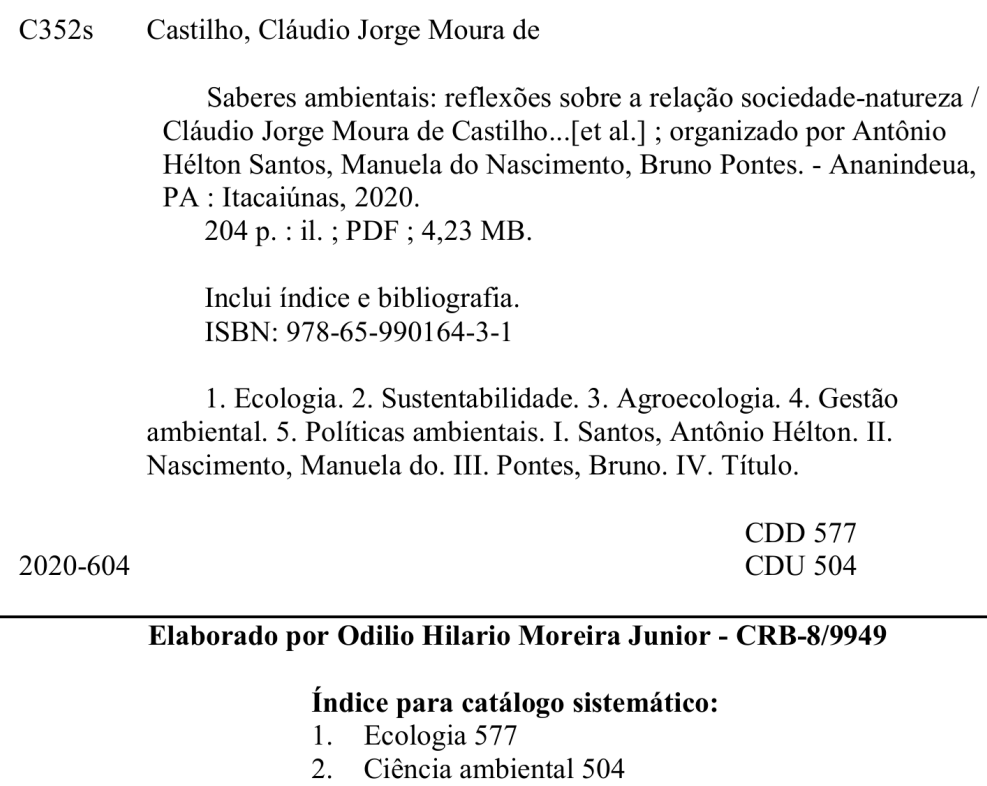

1. Ecologia. 2. Sustentabilidade. 3. Agroecologia. 4. Gestão ambiental. 5. Políticas ambientais. I. Santos, Antônio Hélton. II. Nascimento, Manuela do. III. Pontes, Bruno. IV. Título.

$\begin{array}{ll}\text { 2020-604 } & \text { CDD } 577 \\ & \text { CDU } 504\end{array}$

Elaborado por Odilio Hilario Moreira Junior - CRB-8/9949

Índice para catálogo sistemático:

1. Ecologia 577

2. Ciência ambiental 504

DOI: 10.36599/itac-ed1.002

O conteúdo desta obra, inclusive sua revisão ortográfica e gramatical, bem como os dados apresentados, são de responsabilidade de seus participantes, detentores dos Direitos Autorais. Esta obra foi publicada pela Editora Itacaiúnas em abril de 2020. 


\section{SOBRE OS ORGANIZADORES}

\section{Antônio Hélton Vasconcelos dos Santos}

Mestre e Doutorando em Desenvolvimento e Meio Ambiente na Universidade Federal de Pernambuco (PRODEMA - UFPE). Licenciado em Geografia pela Universidade de Pernambuco (UPE), Licenciado em Pedagogia por intermédio do Centro Universitário Internacional (UNNITER), discente do curso de bacharelado em Geografia na Universidade Federal de Pernambuco (UFPE), possui Especializações em: Ensino de Geografia pelas Faculdades Integradas da Vitória de Santo Antão (FAINTVISA), Gestão Ambiental e Metodologias do Ensino de Geografia ambas por meio da Faculdade Mantenense dos Vales Gerais (Intervale). Tem experiência na área de Geografia, Pedagogia e Gestão Ambiental, atuando principalmente nos seguintes temas: pedagogia de projetos, didática geral, ensino de geografia, educação ambiental, degradação de ecossistemas, impactos ambientais, desenvolvimento com sustentabilidade e produção de cerâmicas vermelhas. Atualmente é Membro Pesquisador do Grupo Movimentos Sociais e Espaço Urbano (MSEU), como também professor estatutário do Município de Santa Cruz do Capibaribe - PE.

\section{Manuela Maria Pereira do Nascimento}

Doutora em Desenvolvimento e Meio Ambiente (PRODEMA/Universidade Federal de Pernambuco - UFPE). Mestre em Desenvolvimento e Meio Ambiente pela Universidade Federal de Sergipe. Graduada em Geografia (UFPE). Atua nas áreas de Planejamento Urbano, Cartografia Digital e Sistemas de Informação. Tem experiência profissional no ensino de Geografia e interdisciplinar, bem como em projetos de pesquisa e extensão nas seguintes temáticas: geoprocessamento, gestão urbana e ambiental. Pesquisadora do Grupo Movimentos Sociais e Espaço Urbano (MSEU - UFPE).

\section{Bruno Augusto Nogueira Monteiro Pontes}

Doutorando pelo Programa de Pós-graduação em Desenvolvimento e Meio Ambiente (PRODEMA) da Universidade Federal de Pernambuco (UFPE), Mestre em Desenvolvimento e Meio Ambiente (PRODEMA/UFPE) e Geógrafo pela UFPE. Atuou como Bolsista do Conselho Nacional de Desenvolvimento Científico e Tecnológico (CNPQ) e como pesquisador colaborador do Núcleo de Gestão Urbana e Políticas Públicas (NUGEPP/UFPE). Atualmente é membro do grupo de pesquisas Movimentos Sociais e Espaço Urbano (MSEU) da UFPE. Integra o projeto de pesquisa de cooperação internacional, 'Territori, Sostenibilità, Università', entre a UFPE e a Università di Bologna (UNIBO), tendo participado da jornada de trabalho sobre o projeto de pesquisa na UNIBO, em 2018. Desenvolve pesquisas no âmbito da relação Sociedade-Natureza em sua complexidade, abarcando, sobretudo, as áreas da Geografia Humana, Desenvolvimento Urbano, Planejamento e Governança Ambiental. 


\section{AGRADECIMENTOS}

Ao Grupo de Pesquisa Movimentos Sociais e Espaço Urbano - MSEU pelo apoio e incentivo na idealização da construção desta coletânea. Ao Programa de Pós-graduação em Desenvolvimento e Meio Ambiente e a Coordenação de Aperfeiçoamento de Pessoal de Nível Superior (CAPES) pela concessão de bolsas para os referidos organizadores. 


\section{SUMÁRIO}

APRESENTAÇÃ

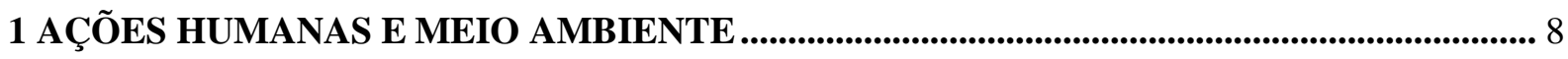

I. GEOGRAFIA: UM SABER AMBIENTAL NECESSÁRIO …................................................. 9 Cláudio Jorge Moura de Castilho

II. GLOBALIZAÇÃO E CRISE AMBIENTAL: REVISITANDO ARGUMENTOS PARA UMA CRÍTICA DO DESAFIO ECOLÓGICO CONTEMPORÂNEO …...................................................... 25 Otávio Augusto Alves dos Santos

III. A VALORAÇÃO DO CAPITAL NATURAL FRENTE AO MERCADO, AO ESTADO E À SOCIEDADE.

Ana Karoline de Carvalho Silva

Assíria Marielle da Silva Dantas

Ana Márcia Moura da Costa

IV. MOVIMENTO AMBIENTALISTA E DESENVOLVIMENTO SUSTENTÁVEL: ORIGENS, PERSPECTIVAS E INFLUÊNCIAS

Rennisy Rodrigues Cruz

José Roberto Galdino de Barros Filho

Fabiano Duarte Machado

$\infty$ ELO UM 68

Bruno Augusto Nogueira Monteiro Pontes

2 DIAGNÓSTICO, GESTÃo AMBIENTAL E POLÍTICAS PÚBLICAS 74

V. DIAGNÓSTICO SOCIOAMBIENTAL DO DELTA DO PARNAÍBA NA REGIÃO LITORÂNEA DO PIAUÍ-BRASIL 75

João Pinto Cabral Neto

Flávia Regina Sobral Feitosa

Wagner José de Aguiar

Bruno Augusto Nogueira Monteiro Pontes

VI. GESTÃO AMBIENTAL EM MEIOS DEHOSPEDAGENS NO MUNICÍPIO DE TAMANDARÉ

- PERNAMBUCO 91

Áurea Nascimento de Siqueira Mesquita

Wagner José de Aguiar

Vanice Santiago Fragoso Selva

VII. A CIDADANIA AMBIENTAL POR MEIO DE POLÍTICAS PÚBLICAS NO BRASIL 103

Flávio Marcelo Rodrigues Bruno

Raimundo Giovanni França Matos

Jonhanny Mariel Leal Fraga

Rubio José Ferreira

$\infty$ ELO DOIS ...... 


\section{FENÔMENOS AMBIENTAIS, COMUNIDADES TRADICIONAIS E}

GEOPROCESSAMENTO.

VIII. FENÔMENOS AMBIENTAIS, BIODIVERSIDADE DA PAISAGEM E INTERAÇÕES

ANTRÓPICAS.

Rejane Magalhães de Mendonça Pimentel

Luiz Henrique Gonçalves da Silva

IX. INTERAÇÕES ANTRÓPICAS NO AMBIENTE: SENSORIAMENTO REMOTO NA

IDENTIFICAÇÃO DE ALTERAÇÕES NA PAISAGEM.

Gabriela Macêdo Aretakis de Almeida

Rejane Magalhães de Mendonça Pimentel

Carolina Alves Collier de Almeida

Miguel Santana de Almeida Neto

X. A TEORIA DO FORRAGEAMENTO ÓTIMO COMO FERRAMENTA NO ESTUDO DE COMUNIDADES DE PESCADORES ARTESANAIS.

Miguel Santana de Almeida Neto

Carolina Alves Collier de Almeida

Gabriela Macedo Aretakis de Almeida

Ana Carla Asfora El-Deir

José da Silva Mourão

XI. HOMENS OU MULHERES NA PESCA: NOVOS PARADIGMAS DA MARISCAGEM NO

NORDESTE DO BRASIL

Ivo Raposo Gonçalves Cidreira-Neto

Gilberto Gonçalves Rodrigues

XII. ENTRE A RELAÇÃO SOCIEDADE E NATUREZA E O DIREITO SOCIOAMBIENTAL: HÁ

LUGAR PARA AS COMUNIDADES TRADICIONAIS DO OESTE BAIANO? 161

Flávio Marcelo Rodrigues Bruno

Rubio José Ferreira

Andyara Andreza Marques Morais

XI. COMPLEXIDADE E TRANSDISCIPLINARIDADE: DESAFIOS E POSSIBILIDADES NA OPERACIONALIZAÇÃO COLETIVA DE PESQUISAS SOBRE O AMBIENTE

Gabriela Macedo Aretakis de Almeida

Gilberto Queiroz de Lima Filho

José Eleno da Silva

Lívia Câmara Machado

Lywistone Galdino da Silva

Manuela Maria Pereira do Nascimento

Patrícia Alves Pereira

Plínio Guimarães de Sousa

Vanessa Bastos Simões da Costa

Tiago Henrique de Oliveira

$\infty$ ELO TRÊS 


\section{APRESENTAÇÃO}

A obra "Saberes Ambientais: reflexões sobre a relação sociedade-natureza" reúne perspectivas sobre as ações antrópicas no meio ambiente, por meio de uma abordagem interdisciplinar. Essa coletânea surgiu no âmbito das discussões entre os membros do grupo de pesquisa Movimentos Sociais e Espaço Urbano - MSEU, com o intuito de publicar relatos de pesquisa, estudos teóricos e revisões críticas da literatura a fim de contribuir no debate acadêmico sobre a necessidade da interação sinérgica entre as atividades humanas e o ambiente buscando uma sustentabilidade.

Para tanto, estrutura-se nos seguintes eixos temáticos: Ecologia, biodiversidade e paisagem; Agroecologia e agricultura familiar; Comunidades tradicionais e etnociência; Educação e epistemologia ambiental; Gestão, indicadores e políticas ambientais; Turismo, sustentabilidade e áreas protegidas; Produção do espaço, dinâmicas territoriais e movimentos sociais; Tecnologias e saneamento ambiental; Mudanças climáticas, Recursos hídricos e vulnerabilidade; Saúde e meio ambiente; e por fim, Geoprocessamento, sensoriamento remoto e modelagem.

Os capítulos apresentam abordagens inter-relacionadas com as discussões ambientais associadas aos fenômenos sociais, de forma a não se limitarem apenas aos referidos eixos temáticos, privilegiando o diálogo com os diversos campos do saber. Deste modo, almeja demonstrar a interdisciplinaridade que possibilita superar uma hiper-especialização firmada na formação acadêmica e na produção científica que pouco tem privilegiado o diálogo e o debate entre as diversas ciências para assuntos que, direta ou indiretamente, convergem mutuamente.

Ademais, tendo em vista que os trabalhos com o foco ambiental assumem perspectivas interdisciplinares, mediante a complexidade que assumem, reforça-se a importância da interdisciplinaridade para além dos estudos das ciências ambientais, sendo necessária não só para preservar e conservar os recursos, mas para construção de debates que visem ao entendimento das ações antrópicas em interação com a natureza de forma crítica e analítica. Busca-se, assim, trazer bases para um desenvolvimento sensível às problemáticas ambientais, fortalecido por uma ética e uma moral que considere a racionalidade ambiental. É partindo destes pressupostos que a obra "Saberes Ambientais: reflexões sobre a relação sociedadenatureza" articula a comunidade científica para uma produção acerca da atual situação do nosso planeta, considerando a aceleração dos efeitos, benéficos ou controversos, das ações e transformações em curso. 


\section{AÇÕES HUMANAS E MEIO AMBIENTE}




\title{
GEOGRAFIA: UM SABER AMBIENTAL NECESSÁRIO
}

\author{
Cláudio Jorge Moura de Castilho ${ }^{1}$
}

\section{CONSIDERAÇÕES INICIAIS}

Este ensaio possui como principal escopo provocar uma reflexão acerca de como a geografia constitui, efetivamente, um campo do conhecimento científico-social, ao mesmo tempo, pensado e praticado como um saber ambiental necessário para o Bem Viver dos homens e das mulheres na Terra. Compreende-se o Bem Viver, seguindo a ideia de Acosta (2016), como "uma oportunidade para imaginar outros mundos".

A retomada da referida reflexão, hoje mais do que nunca, faz-se relevante visto que, no âmbito acadêmico, ainda nos esbarramos em um conjunto de adversidades que acabam limitando o papel crítico-progressista da ciência na sociedade, fragmentando-a em disciplinas as quais, per se, não conseguem explicar os problemas sociais em sua complexidade. Desse modo, as disciplinas acadêmicas terminam sendo reduzidas a meros instrumentos de poder de uma academia voltada, preponderantemente, para os interesses da lógica da racionalidade técnico-instrumental do capitalismo neoliberal.

Para evitar o predomínio destes interesses no processo de uso permanente do território, ter-se-á que começar pela quebra dos discursos acadêmicos os quais, muitas vezes, por imposição, fazem-se hegemônicos, visando tornarem-se verdades absolutas a fim de engessar o status quo no interior da academia e, por conseguinte, reverberando-se para as demais instituições sociais.

Vale ressaltar que o reconhecimento do problema citado no parágrafo anterior levou Foucault (2010, p. 227-228) a desenvolver o seguinte raciocínio:

\footnotetext{
${ }^{1}$ Professor Associado do Departamento de Ciências Geográficas da Universidade Federal de Pernambuco e Bolsista de Produtividade em Pesquisa N-1 do CNPq, e-mail: claudiocastilho44@gmail.com.
} 
[...] achei que, no momento, era o essencial: libertar a história do pensamento de sua sujeição transcendental. O problema para mim não era, absolutamente, estruturalizála, aplicando ao devir do saber ou a gênese das ciências categorias que tinham sido testadas no domínio da língua. Tratava-se de analisar tal história em uma descontinuidade que nenhuma teleologia reduziria antecipadamente: demarcá-la em uma dispersão que nenhum horizonte prévio poderia tornar a fechar; deixar que ela se desenrolasse em um anonimato em que nenhuma constituição transcendental imporia a forma do sujeito; abri-la a uma temporalidade que não prometeria o retorno de nenhuma aurora. Tratava-se de despojá-la de qualquer narcisismo transcendental; era preciso libertá-la da esfera da origem perdida e reencontrada em que estava presa: era preciso mostrar que a história do pensamento não podia ter o papel revelador do momento transcendental que a mecânica racional já não tem desde Kant, nem as idealidades matemáticas desde Husserl, nem as significações do mundo percebido desde Merleau-Ponty - a despeito dos esforços que foram feitos para aí descobri-lo.

Trata-se, portanto, de conceber a história dos homens e das mulheres como um processo sempre aberto ao efetivamente novo, movimentando-se em alguma direção de cujo fim nunca se sabe precisamente qual é. Na verdade, somente a história pode indicar-nos o que se busca como fim, razão por que a ciência também deve ser concebida como um processo dinâmico e aberto para se pensar o mundo, a fim de acompanhar o acontecer histórico territorial como uma totalidade complexa.

A realização do objetivo acima apresentado fundamentou-se em, basicamente, dois procedimentos metodológicos a saber: a nossa percepção, como docente-pesquisador-cidadão, do papel da geografia, como um saber ambiental necessário às práticas sociais no território, bem como a realização de uma revisão da literatura que estamos fazendo desde quando ingressamos, como geógrafo-docente, no Programa de Pós-Graduação em Desenvolvimento e Meio Ambiente da Universidade Federal de Pernambuco.

Estando, portanto, em permanente processo de gestação, de acordo com Leff (2009, p. 145), o saber ambiental, como suporte para a elaboração e prática da racionalidade ambiental, contraposta à racionalidade técnico-instrumental capitalista neoliberal,

[...] problematiza o conhecimento fragmentado em disciplinas e a administração setorial do desenvolvimento, para construir um campo de conhecimentos teóricos e práticos orientado para a rearticulação das relações sociedade-natureza. [...] O saber ambiental excede as 'ciências ambientais', constituídas como um conjunto de especializações surgidas da incorporação de enfoques ecológicos às disciplinas tradicionais [...] e se estende além do campo de articulação das ciências [...], para abrir-se ao terreno dos valores éticos, dos conhecimentos práticos e dos saberes tradicionais.

No âmbito desta perspectiva, compreende-se a geografia como um conhecimento que, vinculado ao mundo da vida dos homens e das mulheres durante a sua existência nos seus territórios de vida e trabalho, deve dialogar com os demais conhecimentos, no curso do movimento permanente da história humana. Processo que deve acontecer, vale ressaltar, junto 
às diversas experiências de resistência e luta sociais inerentes a uma sociedade de classes a partir dos territórios que se constroem nas cidades e nos campos do mundo.

Diante do exposto, este texto foi estruturado de maneira a, primeiramente, abordar a natureza concreta da geografia como um saber ambiental; para, em seguida, retomar o encorajamento do exercício da práxis como uma tarefa difícil, mas possível, no âmbito da filosofia da práxis; depois, refletir ainda sobre o que fazer visando reforçar as lutas territoriais pela mudança social na busca do Bem Viver; e, por fim, a colocação de uma conclusão com a finalidade precípua de encorajar a continuidade desta discussão.

\section{A GEOGRAFIA COMO UM SABER AMBIENTAL}

A geografia sempre constituiu um saber ambiental construído no âmbito das interrelações dialéticas entre as dimensões da sociedade e natureza, no curso da história humana, muito embora tenha-se presenciado um certo afastamento entre essas duas dimensões, notadamente com o aprofundamento do processo de introdução das relações capitalistas simultaneamente como materialidade e imaterialidade - em toda parte do Mundo.

É através do saber geográfico, intrinsecamente atrelado a uma perspectiva inter/transdisciplinar, que os homens e as mulheres compreendem as intencionalidades que se acham por detrás das ações dos atores dominantes que produzem o espaço geográfico - nas suas manifestações urbana e rural - como uma totalidade complexa em permanente movimento.

No âmbito do referido movimento, o espaço geográfico é compreendido como um campo de forças, ou seja, como uma arena de disputas entre os diversos atores sociais Famílias, Estado, Complexo Fundiário Imobiliário Comercial Financeiro (CFICF), Movimentos Sociais, etc. - que ocupam e apropriam-se de porções deste espaço a fim de produzirem os seus respectivos territórios como bases dos ambientes de existência, segundo os interesses conflituosos de classe. Nesse sentido,

$\mathrm{O}$ ambiente configura um conceito e um objeto mais complexo que o pensamento ecologista; a partir da ótica questionadora das externalidades geradas pelos critérios produtivistas de curto prazo, problematiza a racionalidade social imposta pela ordem econômica dominante. $\mathrm{O}$ ambiente, entendido como potencial produtivo que gera articulação sinérgica da produtividade ecológica, a inovação tecnológica, a autogestão produtiva e a participação popular, é um projeto mais rico que o da adaptação tecnológica dos processos produtivos a um funcionalismo ecologista. $\mathrm{O}$ ambientalismo se orienta assim para o melhoramento da qualidade de vida através de novas alternativas de desenvolvimento fundadas no potencial ambiental das diferentes regiões e comunidades. (LEFF, 2009, p. 116) 
No âmbito desta perspectiva, o espaço geográfico passa a ser evidenciado como sustentáculo dos diversos ambientes socialmente construídos, tornando-se, assim, uma totalidade complexa; a qual é, permanentemente, tecida a partir de contradições que suscitam visões de mundo da parte dos homens e das mulheres capazes de engendrar conflitos saudáveis através dos quais a realidade é constantemente questionada, problematizada e refeita em um sentido diferente com relação ao que está posto.

Em espaços que foram produzidos sob contexto de formação territorial fundamentada na lógica do desenvolvimento histórico-geográfico desigual e combinado, a realidade continua sendo repensada e refeita ainda para atender, preponderantemente, os imperativos da racionalidade técnico-instrumental capitalista, hoje marcada pelos imperativos do neoliberalismo.

Por outro lado, na perspectiva de um processo teórico-prático que acontece por meio de movimentos sociais fortes o suficiente para promoverem mudanças institucionais em favor das territorialidades construídas pelas classes sociais subalternas e oprimidas, a geografia possui capacidade para tornar-se um saber ambiental fundamental. Isto, não somente para a conquista do Bem-Estar Social, mas, simultaneamente, para o Bem Viver dos homens e das mulheres a partir dos seus respectivos territórios de existência.

A ideia do Bem-Estar Social, sob a coordenação de um Estado Democrático de Direito, refere-se, principalmente, a um estado de vida em que os homens e as mulheres têm garantidos os seus direitos a um conjunto de bens de consumo coletivo (saúde, educação, segurança, cultura, lazer, etc.) através de políticas públicas providas pelo Estado, com certo grau de participação no que tange à gestão dos problemas por eles/elas enfrentados cotidianamente.

Por outro lado, indo além das garantias acima ressaltadas, a ideia do Bem Viver, complementando, na nossa opinião, a ideia anteriormente apresentada de Bem-Estar, constitui uma visão de mundo mediante a qual podemos reaproximarmo-nos da complexidade da problemática territorial. Refletindo acerca do Bem Viver. Este, segundo Costa (2019, p. 151),

\footnotetext{
[...] nasceu das tradições indígenas, mais precisamente no Equador, formalmente através da sua Constituição Federal em 2008, com a expressão 'Buen Vivir', também é previsto na Constituição da Bolívia de 2009, como 'Vivir Bien', surgindo assim o novo constitucionalismo da América Latina que prega o pluralismo jurídico diante do respeito ao saber tradicional dos ancestrais, do multiculturalismo indígena, do respeito à natureza, da conexão entre homem e natureza, do ser humano individualmente e deste com a sociedade...
}

Nesse sentido, concretamente, o Bem Viver significa ter respeito à outridade em sua diversidade e complexidade, ou seja, a tudo o que nos cerca: as pessoas, as suas culturas, e os 
elementos da natureza (águas, vegetação, solo, ar, etc.) na perspectiva de Bens Comuns, como uma totalidade inacabada e em movimento. Paralelamente, o Bem Viver também significa terse a liberdade de, com autonomia, buscar-se livremente outros caminhos mais justos e equitativos para uma existência humana concretamente digna na Terra.

\begin{abstract}
Para romper com a realidade que se esconde por trás da ideia de 'viver melhor' dentro do capitalismo, é urgente buscar novas formas de vida, revitalizando a discussão política ofuscada pela visão economicista. Uma consequência direta disso é a necessidade de deter a mercantilização da vida, sobretudo da Natureza. É preciso desmercantizá-la. Temos que nos reencontrar com ela, assegurando sua capacidade de regeneração, baseada no respeito, na relacionalidade e na reciprocidade. E, simultaneamente, há que assegurar a justiça social para todos os habitantes do planeta. [...] Ao propor a harmonia com a Natureza e entre indivíduos e comunidades, e ao estar carregado de experiências de vida e resistência, o Bem Viver, sempre que esteja livre de preconceitos e seja assumido como uma proposta em construção, permite formular visões alternativas de estar no mundo... (ACOSTA, 2016, p. 17).
\end{abstract}

No que diz respeito à ideia acima referenciada, a geografia vem sentindo a necessidade de reaproximar-se da ecologia no sentido não somente de resgatar a sua própria natureza como conhecimento científico, mas, ao mesmo tempo, no de tornar-se mais útil para explicar o mundo hodierno. Neste sentido, acentuando a referida reaproximação, sob a perspectiva de uma ecogeografia, Raffestin (2012, p. 35) defende que

\begin{abstract}
É de extrema importância que uma ecogeografia não seja considerada apenas como um 'mundo envolvente', mas ao mesmo tempo como um 'mundo com'. Isto muda completamente a concepção do antropocentrismo clássico que em lugar de colocar o homem 'no meio do mundo' como um elemento privilegiado, coloca-o como aquele que vive com todos, através de tudo e em relação com tudo o que faz o mundo. O fato que o homem atravessa e seja atravessado por tudo no mundo obriga a reconsiderar nossa posição, a fazer de uma certa maneira uma 'revolução copernicana', ou seja, não negligenciando o ambiente humano [...] no qual, justamente, acreditamos estarmos submergido. (tradução livre realizada pelo autor deste ensaio)
\end{abstract}

O saber geográfico pode ser eficaz no desenvolvimento de tais ideias a partir dos territórios vividos pelos homens e pelas mulheres no seu cotidiano, reforçando o caráter deste campo do conhecimento como um saber e um fazer - enquanto efetivamente uma práxis transformador, ou seja, capaz de engendrar algo efetivamente diferente do que existe.

\begin{abstract}
A emergência do saber ambiental abriu novas frentes para o desenvolvimento das disciplinas sociais: a relação entre cultura e natureza, a complementaridade entre geografia e ecologia, a influência do meio na consciência e no comportamento social, as bases ecológicas de uma economia sustentável e a análise da dinâmica de sistemas socioambientais complexos. Desta maneira, o saber ambiental transforma o campo do conhecimento gerando novos objetos interdisciplinares de conhecimento, novos campos de aplicação e novos processos sociais de objetivação onde se constrói a racionalidade ambiental. (LEFF, 2009, p. 151)
\end{abstract}

Uma vez que teoria e prática constituem dimensões articuladas da vida humana no mundo, a dinâmica da realidade supra esboçada reforça e/ou reformula a formação de uma geografia que, também em permanente movimento dialético, intenciona contribuir, 
politicamente, para pensar, refletir e interagir junto com os homens e as mulheres no seu processo histórico de mudança territorial permanente na história.

No âmbito da perspectiva de práxis supramencionada, segundo Lacoste (1988), é preciso "saber pensar o espaço para saber nele se organizar, para saber ali combater", pois somente assim é que se pode concretizar algo efetivamente diferente em termos de território. Mas o que seria um território diferente?

Partindo da ideia da diferença como algo inerente ao respeito à diversidade territorial e, ao mesmo tempo, rejeitando veementemente as injustiças e desigualdades - que, ao contrário, constituem resultados de privilégios de classe, gênero, raça, orientação religiosa, opção sexual, etc. - inerentes a uma sociedade de classes; defende-se a organização e mobilização contínuas no tempo-espaço dos homens e das mulheres a fim de que consigam combater a permanência dos mecanismos que lhes impedem de conquistarem o "direito ao entorno" e, por conseguinte, o "espaço do cidadão", sabiamente definidos e defendidos por Santos (1987).

É nessa perspectiva que a geografia ${ }^{2}$ torna-se um saber ambiental norteador de um fazer necessário à produção de outro espaço, para o qual, aliás, a práxis constitui uma ação teórico-prática essencial, reunindo as condições materiais e imateriais necessárias à compreensão e à ação junto ao/com o mundo em seu permanente acontecer histórico.

\section{GEOGRAFIA DA PRÁXIS - UMA SUPERAÇÃO DIFÍCIL, MAS POSSÍVEL}

Ainda existem muitas incompreensões, dúvidas e dificuldades no que diz respeito ao conceito de práxis, sobretudo no âmbito da academia a qual ainda insiste em continuar realizando pesquisas e a elaborar ideias distantes das territorialidades dos homens e das mulheres que produzem, ao longo da sua vida cotidiana, os seus próprios territórios na cidade e no campo.

Pela razão acima colocada, antes de mais nada, vale ressaltar o que se tem entendido e, concomitantemente, praticado como práxis a fim de que se possa dar prosseguimento à reflexão ora proposta. O que pode ser devidamente esclarecido através de uma síntese realizada por Abbagnano (2012, p. 922).

Com esta palavra [práxis] (que é a transcrição da palavra grega que significa ação), a terminologia marxista designa o conjunto de relações de produção e trabalho, que constituem a estrutura social, e a ação transformadora que a revolução deve exercer sobre tais relações. Marx [em A Ideologia Alemã] dizia que é preciso explicar a

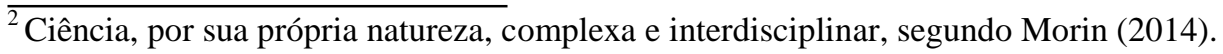


formação das ideias a partir da 'práxis material', e que, por conseguinte, formas e produtos da consciência só podem ser eliminados por meio da 'inversão prática das relações sociais existentes', e não por meio da 'crítica intelectual'. [...] Por 'inversão da P.', Engels [em Antidüring] entendeu a reação do homem às condições materiais da existência, sua capacidade de inserir-se nas relações de produção e de trabalho e de transformá-las ativamente: esta possibilidade é a subversão da relação fundamental entre infra-estrutura e superestrutura, em virtude da qual é somente a primeira (a totalidade das relações de produção e de trabalho) que determina a segunda, constituída pelo conjunto das atividades espirituais humanas.

Nesta perspectiva, teoria e prática - saber e fazer - constituem dimensões dialeticamente articuladas e associadas como uma totalidade complexa em processo permanente de ressignificação a fim de, como práxis, conseguir acompanhar os diferentes momentos do processo histórico. Caso contrário, ou seja, se a dialética é derrotada pelas classes sociais dominantes, aquelas refratárias à democracia, correr-se-á o risco de ver o pêndulo da história, mais uma vez, pender para regimes autoritários. Com efeito, a história constitui, segundo Arendt (1989), um processo cujo movimento engendra ciclos de avanços e de retrocessos os quais dependem das vicissitudes próprias de cada contexto histórico-espacial e político no mundo ${ }^{3}$.

Portanto, este caráter espiral da história vem acompanhando o processo civilizatório da humanidade, daí por que os homens e as mulheres têm que estar sempre atentos para que os ciclos de retrocessos não consigam concretizar-se, pondo fim à dialética e dificultando o florescimento do contraditório, movimento que é salutar em todas as escalas da vida humana. A este respeito, Konder (1988, p. 9) argumentou que

O modelo de pensar dialético - atento à infinitude do real e à irredutibilidade do real
ao saber - implica um esforço constante da consciência no sentido de ela se abrir
para o reconhecimento do novo, do inédito, da contradição que irrompem no campo
visual do sujeito e lhe revelam a existência de problemas que ele não estava
enxergando. A exigência do reconhecimento de todas as contradições pode entrar
em choque (e, de fato, com frequência entra) com exigências de outro tipo, que são
as exigências ligadas às tarefas práticas urgentes que a luta política apresenta aos
revolucionários. Em determinadas circunstâncias, o reconhecimento da
complexidade e da contraditoriedade do quadro da ação pode paralisar - ou ao
menos entorpecer - a intervenção eficaz do sujeito no combate; em tais
circunstâncias, os dirigentes políticos das forças pragmaticamente comprometidas
com a mudança tendem a mobilizá-las através de fórmulas não dialéticas, cujo 3 Tal como temos visto acontecer nos últimos cinco anos no Brasil, notadamente após o golpe que derrubou a
Presidenta Dilma Vanna Rousseff do Partido dos Trabalhadores (PT). O que teve forte apoio da mídia comercial
conservadora na medida em que contribuiu para a disseminação do ódio ao PT: "Quando as classes médias
indignadas saíram às ruas a partir de junho de 2013 , não foi, certamente, pela corrupção do PT, já que os
revoltosos ficaram em casa quando a corrupção dos outros partidos veio à tona. Por que a corrupção do PT
provocou tanto ódio e a corrupção de outros partidos é encarada com tanta naturalidade? É que o ódio ao PT, na
realidade, foi o ódio devotado ao único partido que diminuiu as distâncias sociais entre as classes no Brasil
moderno. A corrupção foi mero pretexto. Não houve, portanto, nos últimos 150 anos, um efetivo aprendizado
social e moral em direção a uma sociedade inclusiva entre nós" (SOUZA, 2017, p. 67). Enfim, o ódio ao PT
representa, historicamente, o ódio secular da "elite do atraso" aos pobres de hoje como continuidade histórica do
ódio ao escravo durante os três primeiros séculos de formação territorial do Brasil. 
efeito lhes parece ser mais direto e imediato. Além disso, não podemos esquecer o fato de que os revolucionários são seres formados pela própria sociedade que estão negando, de modo que estão sempre marcados pelo mundo que desejam modificar.

Daí por que, fundamentando-se na Filosofia da Práxis de Gramsci, pode-se, junto com o autor acima citado, reconhecer o caráter árduo e difícil do exercício da dialética, na medida em que o pensar dialético como necessário ao novo, ao diferente, ao efetivamente histórico, sempre colide com o senso comum - dogmático e ávido de certezas - dificultando os caminhos a serem trilhados na busca do bom senso.

Por isso, rejeita-se qualquer tipo de autoritarismo, seja de esquerda seja de direita, razão pela qual, a despeito da dificuldade no que tange ao combate ao seu acontecer histórico, os homens e as mulheres têm que continuarem atentos e preparados; notadamente no período atual da história em que a força da cultura neoliberal esconde de maneira assaz eficaz a perversidade do capitalismo neoliberal no Brasil, impedindo o afloramento das possibilidades efetivas de mudança.

Porém, onde residem estas possibilidades? A resposta é fácil, entretanto o como fazer é que ainda é difícil de se implementar porque não existem certezas e verdades eternas, pelo menos no que se refere à ação. Primeiramente, tem-se que, utilizando-nos da heurística, descobri-las no acontecer histórico do mundo da vida dos homens e das mulheres que ainda continuam alijados e/ou precariamente incluídos na sociedade, ou seja, daquelas pessoas que fazem parte das classes sociais subalternas e oprimidas.

Denominando as classes acima referidas como "os de baixo", Santos (2000, p. 146-

147) colocou que elas são as que devem ser valorizadas como protagonistas do processo de mudança dos seus próprios territórios. Isto porque

Da divisão do trabalho por cima cria-se uma solidariedade gerada de fora e dependente de vetores verticais e de relações pragmáticas frequentemente longínquas. A racionalidade é mantida à custa de normas férreas, exclusivas, implacáveis, radicais. Sem obediência cega não há eficácia. Na divisão do trabalho por baixo, o que se produz é uma solidariedade criada de dentro e dependente de vetores horizontais cimentados no território e na cultura locais. Aqui são as relações de proximidade que avultam, este é o domínio da flexibilidade tropical com a adaptabilidade extrema dos atores, uma adaptabilidade endógena. A cada movimento há um novo reequilíbrio em favor da sociedade local e regulado por ela. [...] Por baixo há maior dinamismo intrínseco, maior movimento espontâneo, mais encontros gratuitos, maior complexidade, mais riqueza (a riqueza e o movimento dos homens lentos), mais combinações. Produz-se uma nova centralidade do social, segundo a fórmula sugerida por Ana Clara Torres Ribeiro, o que constitui, também, uma nova base para a afirmação do reino da política (SANTOS, 2000, p. 146-147).

Nesse sentido, a política que interessa ao que se pode definir e buscar como outro mundo, segundo este mesmo autor, deve ser a "política dos pobres", ou seja, a política de quem efetivamente vive as carências no tempo-espaço do acontecer histórico da vida 
cotidiana, criando táticas e estratégias a fim de continuarem existindo num mundo pleno de adversidades à sua reprodução social, processo que nunca tem um fim e que está em permanente movimento em algum sentido.

Os homens e as mulheres pobres, a partir dos seus próprios territórios de existência, constituem os atores principais da geografia da práxis, razão pela qual são eles e elas quem devem indicar o que realmente lhes interessa em termos de processo de uso do território, através de pressões para que se façam valer, na cidade, gestões urbanas efetivamente participativas.

O processo acima ressaltado deve acontecer em todas as escalas do acontecer histórico-geográfico dos homens e das mulheres, isto é, desde a escala da sua vida cotidiana até às escalas espaciais da cidade e do campo, do país e do mundo nas quais os territórios destas pessoas estão situados: na organização da vida comunitária do próprio bairro, nos fóruns de discussão dos problemas que lhes afligem (PREZEIS, Orçamento Participativo, no caso do Recife), nas políticas públicas sociais e territoriais, etc.

\section{O QUE FAZER ESPECIFICAMENTE?}

Abrindo esta última seção do presente ensaio com a questão sobre o que fazer especificamente para a concretização de uma Geografia da Práxis - questão que, aliás, os revolucionários europeus haviam formulado, sobretudo, desde o final do século XIX e início do século XX -, retoma-se, concomitantemente, a ideia de que a mudança visando ao novo deve partir de uma práxis efetiva dos "de baixo" no âmbito do tempo-espaço. Porém, com o apoio de um conjunto de instituições sociais comprometidas com a mudança concreta em termos de uso do território, formando uma rede de esperança.

Em sendo assim, partindo de uma multiplicidade sempre aberta em termos de visão de mundo, o novo supracitado não estava, segundo Foucault (2011), no que era dito, mas, ao redor do que se dizia. Em outras palavras, o que interessa de fato é o acontecer históricogeográfico no âmbito do qual se dizem as coisas acerca da existência humana na Terra. Daí por que

[...] existem, ao nosso redor, muitos discursos que circulam, sem receber seu sentido ou sua eficácia de um autor ao qual seriam atribuídos: conversas cotidianas, logo apagadas; decretos ou contratos que precisam de signatários mas não de autor, receitas técnicas transmitidas no anonimato. Mas nos domínios em que a atribuição a um autor é de regra - literatura, filosofia, ciência - vê-se bem que ela não desempenha sempre o mesmo papel; na ordem do discurso científico, a atribuição a um autor era, na Idade Média, indispensável, pois era um indicador de verdade. (FOUCAULT, 2011, p. 26-27) 
Trata-se de um conjunto de ações que se realizam a partir do momento em que teorias são formuladas fundamentadas nas práticas inerentes às territorialidades dos homens e das mulheres no curso das suas histórias de vida e, simultaneamente, a partir de ações fundamentadas em teorias capazes de norteá-las para o entendimento do mundo como uma totalidade complexa em permanente processo de mudança.

Destarte, reitera-se que, as alternativas em termos de soluções - a exemplo de políticas públicas, planos, programas e projetos de desenvolvimento territorial, etc. - para resolverem os problemas existentes nos diversos territórios das nossas cidades e dos nossos campos não podem cair de paraquedas nesses lugares, à revelia, por exemplo, do saber geográfico a eles inerente. Urge, portanto, ultrapassar esta lógica denominada por Sen (2001) de "institucionalismo transcendental" a fim de considerar efetivamente a complexidade dos territórios vividos a partir das falas e percepções de quem lá se encontra.

A este respeito, não se pode esquecer de um dos grandes ensinamentos legados por Freire $(1978 ; 2019)$ segundo o qual, o pronunciar-se sobre o mundo a partir dos seus próprios lugares e das suas próprias experiências de existência é que pode levar os homens e as mulheres a autoconscientizarem-se sobre o seu mundo e, por sua vez, a mudarem-no.

Visando trabalhar para que as pessoas estivessem melhor preparadas para organizar os seus deslocamentos e para expressar sua opinião acerca da produção do seu espaço e constituição das suas territorialidades, bem como para serem capazes de perceber e analisar rapidamente as estratégias dos agentes produtores do espaço, ao mesmo tempo, nas escalas local, nacional e internacional, Lacoste (1988, p. 195) pensou no seguinte caminho metodológico:

Para ajudar os cidadãos ali onde eles vivem a tomar consciência das causas
fundamentais que determinam o agravamento das contradições que eles sofrem
diretamente é preciso, primeiro, fazer a análise em termos concretos e precisos
dessas contradições tais como elas se manifestam ao nível local, sobre os locais de
trabalho e da vida cotidiana, sem esquecer as contradições ecológicas, que são,
frequentemente, um fator de agravamento. Em seguida, é possível mostrar com
precisão que essas contradições locais, que podem ser completamente excepcionais,
decorrem de uma situação 'regional' de conjuntos espaciais mais vastos que se
caracterizam por contradições, as quais convém levar em consideração em termos
mais abstratos e mais gerais. É então possível passar à análise nacional e
internacional, onde as contradições devem ser expressas num nível cada vez mais
avançado de abstração, continuando a ficar solidariamente articuladas à análise das
contradições ao nível regional e local, dos quais as pessoas têm, ao menos em parte,
a experiência concreta.

Tarefas estas que, antes de tudo, têm que ser assumidas pelos próprios homens e pelas próprias mulheres, a partir das suas próprias territorialidades; mas, ao mesmo tempo, 
com a assessoria das diversas instituições materiais e imaginárias da sociedade da qual fazem parte: universidades (grupos de pesquisa), coletivos, movimentos sociais, políticos, etc. No âmbito desta rede de (rel)ações que acontecem a partir da indignação com o existente, vislumbra-se a possibilidade de se ter territórios como, segundo escreveu Santos (1997), lugares efetivamente fortes.

Teoricamente, é fundamental, com base em Souza (2017), deslindar a verdadeira raiz inerente às contradições supramencionadas, ou seja, assumir que a escravidão constitui a principal categoria de análise para explicar a injustiça e a desigualdade territorial que permanecem no Brasil. Com isto, segundo ainda este mesmo autor, deve-se rever as teses do populismo (como mobilização manipulativa das massas) e do patrimonialismo (como privatização do público pelas elites apenas no âmbito do Estado, como se somente o Estado constituísse o lugar da corrupção), bem como abandonar de vez o moralismo vira-lata.

$\mathrm{Na}$ prática, a relevância da preocupação acima colocada reside, sobretudo, no questionamento sobre o fato de que a mudança não acontece apenas com a tomada dos aparelhos físicos do Estado, mas, ao mesmo tempo, com a apropriação dos seus aparelhos ideológicos, visando a um processo de desenvolvimento em que a educação e a cultura constituam efetivamente instrumentos de mudança no sentido do Bem Viver na Terra.

Caso contrário, as referidas teses continuarão, como fábulas no dizer de Santos (2000), mascarando os interesses invisíveis e as ações predatórias do mercado, representado, em nossas cidades pelo CFICF, as quais não respeitam os homens, as mulheres, os negros, os indígenas, os homossexuais e a natureza como Bem Comum.

Com isso, retomar a verdadeira raiz de praticamente todos os problemas sociais vivenciados, hoje, no Brasil, é levar em conta a permanência, sob diversas formas, da escravidão. O que deve ser considerado a fim de, a partir desta retomada, pensar e refletir sobre estratégias concretas de lutas sociais no território. Nesta perspectiva, ainda segundo Souza (2017, p. 151),

O passado que nos domina não é a continuidade com Portugal pré-moderno que nos legaria a corrupção só do Estado, como o culturalismo dominante até hoje entre nós nos diz. Nosso passado intocado até hoje, precisamente por seu esquecimento, é o do escravismo. Do escravismo, nós herdamos o desprezo e o ódio covardes pelas classes populares, que tornaram impossível uma sociedade minimamente igualitária como a europeia. Foi precisamente porque a Europa não teve escravidão que Norbert Elias pôde construir o processo civilizatório europeu a partir da ruptura com a escravidão da antiguidade. O processo civilizatório para Elias é precisamente um gigantesco processo de homogeneização social que abrangeu todas as classes sociais dos principais países europeus, permitindo a construção de patamar mínimo universalizado para todos. Ele foi resultado, portanto, de um processo de aprendizado coletivo de grandes proporções. 
Aqui no Brasil, contudo, não houve este processo de aprendizado coletivo, razão pela qual ainda se nota hoje a permanência de uma sociedade fortemente injusta e desigual; o que, por sua vez, tem sido reforçado pelo Estado que se tem no país, ou seja, um Estado do MalEstar Social, tal como já havida dito o sociólogo pernambucano Francisco de Oliveira.

No que diz respeito ao papel do Estado como agente e espaço público da sociedade, em vez de demonizá-lo e culpá-lo por todas as mazelas sociais, tem-se que resgatá-lo como instituição voltada para os interesses da coletividade social, impedindo que este espaço continue sendo apropriado pela elite do atraso como recurso para o mercado e, por sua vez, para fins de privatização.

Por outro lado, sob os parâmetros da ideia do "Estado como um mal necessário", rediscutida por Castilho (2017a), contraditoriamente, recoloca-se o papel do Estado como relevante para se recuperar o apoio desta instituição sociopolítica da sociedade no fazer valer os interesses da coletividade social.

Como exemplo, cita-se ações de diversos grupos de pesquisa que se acham no interior das Instituições Federais de Ensino Superior (IFES), os quais vêm buscando transpor fronteiras disciplinares - materiais e imateriais - da academia, através do desenvolvimento de atividades de comunicação nos termos colocados por Freire (1977), sob parâmetros da Filosofia da Práxis (Quadro 1).

Quadro 1 - Atividades de Comunicação do Grupo de Pesquisa Movimentos Sociais e Espaço Urbano (MSEU)

\begin{tabular}{|c|c|c|c|}
\hline $\begin{array}{l}\text { ATIVIDADES } \\
\text { REALIZADAS } \\
\end{array}$ & $\begin{array}{c}\text { PROBLEMAS } \\
\text { ENFRENTADOS }\end{array}$ & $\begin{array}{c}\text { AÇÕES } \\
\text { REALIZADAS } \\
\end{array}$ & $\begin{array}{c}\text { METAS } \\
\text { DESEJADAS }\end{array}$ \\
\hline $\begin{array}{c}\text { Interação em processos } \\
\text { de ocupação de } \\
\text { terrenos urbanos e/ou } \\
\text { de consolidação de } \\
\text { terrenos já } \\
\text { conquistados. }\end{array}$ & $\begin{array}{l}\text { Luta pelo direito a } \\
\text { permanecer no terreno } \\
\text { ocupado e/ou pela } \\
\text { melhoria } \\
\text { condições de vida. }\end{array}$ & $\begin{array}{l}\text { Participação do MSEU } \\
\text { nas assembleias; } \\
\text { panfletagem para } \\
\text { mobilização dos } \\
\text { moradores; } \\
\text { desenvolvimento de } \\
\text { oficinas voltadas ao } \\
\text { reforço da mobilização } \\
\text { socioterritorial com } \\
\text { base nas palavras ditas } \\
\text { pelos próprios } \\
\text { moradores em luta; } \\
\text { intermediação entre os } \\
\text { territórios vividos e } \\
\text { instituições da gestão } \\
\text { pública, etc. }\end{array}$ & $\begin{array}{l}\text { Consolidar o processo } \\
\text { de fortalecimento dos } \\
\text { territórios vividos na } \\
\text { busca da concretização } \\
\text { do direito à cidade. }\end{array}$ \\
\hline $\begin{array}{l}\text { Diálogos com alunos } \\
\text { de escolas públicas e } \\
\text { privadas. }\end{array}$ & $\begin{array}{lr}\text { Lacuna } & \text { no } \\
\text { entendimento } & \text { do } \\
\text { espaço geográfico } \\
\text { como uma dimensão }\end{array}$ & $\begin{array}{lr}\text { Debates através } & \text { de } \\
\text { apresentações } & \text { que } \\
\text { representam } & \text { a } \\
\text { problemática } & \text { urbana }\end{array}$ & $\begin{array}{l}\text { Formar indivíduos } \\
\text { capazes de fazerem } \\
\text { uma leitura crítica do } \\
\text { seu mundo, através da }\end{array}$ \\
\hline
\end{tabular}




\begin{tabular}{|c|c|c|c|}
\hline & da cidadania. & $\begin{array}{l}\text { da cidade, politizando } \\
\text { o espaço geográfico, } \\
\text { através dos conteúdos } \\
\text { já trabalhados em sala } \\
\text { de aula pelos } \\
\text { respectivos } \\
\text { professores. }\end{array}$ & geografia. \\
\hline $\begin{array}{l}\text { Diálogos com } \\
\text { professores de } \\
\text { geografia de escolas } \\
\text { públicas e privadas }\end{array}$ & $\begin{array}{ll}\text { Ameaça da } & \text { nefasta } \\
\text { organização } & \text { "Escola } \\
\text { Sem Partido" } & \end{array}$ & $\begin{array}{lr}\text { Discussão de } & \text { técnicas } \\
\text { de } & \text { ensino } \\
\text { fomentadoras } & \text { da } \\
\text { participação } & \text { dos } \\
\text { alunos e do diálogo em } \\
\text { sala de } & \text { aula, } \\
\text { reforçando os } & \text { valores } \\
\text { fundamentais } & \text { à } \\
\text { recuperação } & \text { da } \\
\text { democracia no Brasil. }\end{array}$ & $\begin{array}{l}\text { Apoiar as práticas de } \\
\text { resistência dos } \\
\text { professores } \\
\text { obscurantismo, } \\
\text { encorajando-os a } \\
\text { continuarem na luta } \\
\text { por uma educação } \\
\text { efetivamente voltada } \\
\text { para a democracia. }\end{array}$ \\
\hline
\end{tabular}

Fonte: Banco de dados do MSEU, Universidade Federal de Pernambuco (2019).

Este quadro retrata algumas das atividades de comunicação desenvolvidas pelo MSEU-UFPE junto a territórios e territorialidades que se acham em processo de formação, visando contribuir para que, nos casos ora representados, tornem-se espaços dos cidadãos e das cidadãs capazes de propagar a cidadania para toda a cidade, reforçando que somente assim é que se conseguirá fazer das nossas cidades, espaços não apenas do Bem-Estar, mas, ao mesmo tempo, do Bem Viver.

Nesta perspectiva, desenvolve-se uma prática de Universidade, segundo Morin (2014, p. 82), adaptada às necessidades atuais da sociedade, ou seja, “[...] realizando sua missão transecular de conservação, transmissão e enriquecimento de um patrimônio cultural, sem o que não passaríamos de máquinas de produção e consumo"; patrimônio este que, no caso ora abordado, acha-se vinculado às históricas formas de luta social e que, se reforçado, conseguir-se-á reagir às tentativas atuais de privatização.

Ao mesmo tempo, está-se, através da perspectiva paralela de "hermenêutica das emergências" (SANTOS, 2004), acompanhando as formas através das quais os movimentos e os atores sociais estão percebendo e criando estratégias para resistirem aos imperativos da lógica da racionalidade técnico-instrumental capitalista neoliberal. Com isto, é claro, pretende-se reforçar tais estratégias criadas e praticadas por eles mesmos no curso do seu cotidiano de lutas.

Enfim, não se pode deixar de reiterar que uma série de aparelhos que compõem o Estado deve continuar desempenhando seu papel como instituições efetivamente públicas junto aos movimentos sociais (CASTILHO, 2015; 2017a) e aos espaços de formação da 
cidadania tal como o das escolas e das universidades (CASTILHO, 2019), dando voz a outras territorialidades alijadas da sociedade.

\title{
5 CONSIDERAÇÕES FINAIS
}

Procurou-se, neste ensaio, provocar uma reflexão sobre a geografia como um saber ambiental necessário ao processo conjunto, permanente no tempo, de pensar, produzir e praticar um mundo diferente do que o que aí está a acontecer; e isto na perspectiva de extrapolar a ideia do Bem-Estar, associando-a à do Bem Viver.

Para continuar viabilizando a tarefa acima colocada, o MSEU, através de seus estudos, pesquisas e ações de comunicação em territórios da existência humana, está buscando demonstrar quem de fato vem apropriando-se do espaço geográfico e, por sua vez, de tudo o que ele contém, incluindo a natureza; transformando, por exemplo, os elementos da natureza - Bens Comuns da Humanidade - e o patrimônio cultural da humanidade em mercadorias com a finalidade de gerar riquezas, exclusivamente, para as classes sociais dominantes.

No âmbito de uma Geografia da Práxis, calcada na Filosofia da Práxis, refletiu-se, ainda sob parâmetros de uma utopia concreta, acerca da possibilidade de realizá-la, bem como avançou-se sobre o que se pode fazer especificamente neste sentido. Isto para, como diz Rodrigues (2009), superar o paradigma simplificador das questões sociais, revalorizando o paradigma da complexidade. Com isto, seremos capazes de entender e explicar, por exemplo, o fato de que

\begin{abstract}
A questão ambiental [ou melhor, socioambiental] é fruto, não de desastres naturais, mas de contradições de um modelo desenvolvimentista, agravado nos seus moldes capitalistas em que as camadas mais pobres da sociedade mais sofrem dos impactos ambientais, mas, além disso, são as primeiras indicadas como responsáveis dos mesmos (PROST, 2009, p. 198).
\end{abstract}

Diante disso, destacou-se como a contribuição mais relevante deste escrito, o reconhecimento da geografia - ciência, antes de mais nada complexa e interdisciplinar por sua própria natureza ${ }^{4}$ - como um saber ambiental transformador, que pode ser utilizado por diversos atores sociais em prol do desenvolvimento territorial efetivo dos homens e das mulheres no mundo.

\footnotetext{
${ }^{4}$ Aliás, embora sob o paradigma positivista, o geógrafo Jean Brunhes desenvolveu, na primeira década do século XX, seus estudos considerando a complexidade do mundo, tal como lembrou Castilho (2017b).
} 


\section{REFERÊNCIAS}

ABBAGNANO, Nicola. Dicionário de filosofia. São Paulo: Editora WMF Martins Fontes, 2012.

ACOSTA, Alberto. O bem viver: Uma oportunidade para imaginar outros mundos. São Paulo: Autonomia Literária, Elefante, 2016.

ARENDT, Hannah. Origens do totalitarismo: Antissemitismo, imperialismo, totalitarismo. São Paulo: Companhia das Letras, 1989.

CASTILHO, Cláudio Jorge Moura de. Universidade e experiências de participação no espaço urbano: por uma pedagogia política em territórios vividos por famílias pobres. In: SOUZA, Rosemeri Melo e, SANTOS, Sindiany Suelen Caduda dos, SANTOS, Eline Almeida. (Org.). Vivências e práticas socioambientais: metodologias aplicadas em comunidades. São Cristóvão: GEOPLAN/CNPq/UFS, 2015, p. 27-43.

. Movimentos sociais: uma síntese visando à retomada do seu papel transformador. Revista Movimentos Sociais e Dinâmicas Espaciais, Recife, v. 6, n. 2, 19-38, 2017 a.

Jean Brunhes: a atualidade de um geógrafo do início do século XX. Revista

Movimentos Sociais e Dinâmicas Espaciais, Recife, v. 6, n. 01, p. 253-272, 2017 b.

. Fortalecimento de territórios vividos na encruzilhada dos interesses globais e locais atividades de comunicação em andamento. In: CURY, Mauro José Ferreira, MAGNANI, Elisa, CARVALHO, Rita de Cássia Pereira de. (org.) Ambiente e território: abordagens e transformações sociais. Londrina: Madrepérola, 2019.

COSTA, Ivys Medeiros. A gestão participativa em áreas sobrepostas de unidade de conservação e terra indígena: a situação dos Potiguara na Paraíba. Tese (doutorado em Desenvolvimento e Meio Ambiente), Universidade Federal da Paraíba, 2019.

FOUCAULT, Michel. A arqueologia do saber. $7^{\mathrm{a}}$ ed. Rio de Janeiro: Forense Universitária, 2010.

A ordem do discurso. 21 a ed. São Paulo: Edições Loyola, 2011.

FREIRE, Paulo. Extensão ou comunicação? Rio de Janeio: Paz e Terra, 1977.

Cartas à Gunié-Bissau. Registros de uma experiência em processo. Rio de Janeiro: Paz e Terra, 1978.

Pedagogia do oprimido. $67^{\mathrm{a}}$ ed. Rio de Janeiro: São Paulo: Paz e Terra, 2019.

KONDER, Leandro. A derrota da dialética. A recepção das ideias de Marx no Brasil até o começo dos anos trinta. Rio de Janeiro: Campus, 1988.

LACOSTE, Yves. A geografia: isso serve, em primeiro lugar, para fazer a guerra. Campinas: Papirus, 1988. 
LEFF, Enrique. Saber ambiental: Sustentabilidade, Racionalidade, Complexidade, Poder. Petrópolis: Editora Vozes, 2009.

MORIN, Edgar. A cabeça bem-feita: repensar a reforma, reformar o pensamento. Rio de Janeiro: Bertrand Brasil, 2014.

PROST, Catherine. O falso consenso sobre a defesa do meio ambiente. In: MENDONÇA, Francisco, LOWEN-SAHR, Cicilian Luiza, SILVA, Márcia da (org.). Espaço e tempo: complexidade e desafios do pensar e do fazer geográfico. Curitiba: Associação de Defesa do Meio Ambiente e Desenvolvimento de Antonina, 2009.

RAFFESTIN, Claude. Géographie et écologie. Archive ouverte UNIGE, Genebra, p. 23-36, 2012.

RODRIGUES, Arlete Moysés. A abordagem ambiental unifica as geografias? In: MENDONÇA, Francisco, LOWEN-SAHR, Cicilian Luiza, SILVA, Márcia da (org.). Espaço e tempo: complexidade e desafios do pensar e do fazer geográfico. Curitiba: Associação de Defesa do Meio Ambiente e Desenvolvimento de Antonina, 2009.

SANTOS, Boaventura de Sousa. Para uma sociologia das ausências e uma sociologia das emergências. In: SANTOS, Boaventura de Sousa. Conhecimento prudente para uma vida decente: um discurso sobre as ciências revisitado. São Paulo: Cortez, 2004.

SANTOS, Milton. O espaço do cidadão. São Paulo: Nobel, 1987.

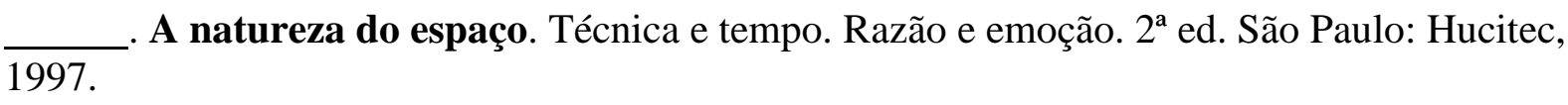

Por uma outra globalização. Do pensamento único à consciência universal. Rio de Janeiro: Record, 2000.

SEN, Amartya. A ideia de justiça. São Paulo: Companhia das Letras, 2001.

SOUZA, Jessé. A elite do atraso. Da escravidão à lava jato. Rio de Janeiro: Leya, 2017. 


\section{GLOBALIZAÇÃO E CRISE AMBIENTAL: REVISITANDO ARGUMENTOS PARA UMA CRÍTICA DO DESAFIO ECOLÓGICO CONTEMPORÂNEO}

Otávio Augusto Alves dos Santos ${ }^{5}$

\section{INTRODUÇÃO}

O objetivo deste capítulo é revisar alguns argumentos teóricos indispensáveis à construção de uma compreensão crítica da chamada crise ambiental, enfatizando sua vinculação com o processo de Globalização. Seguindo os argumentos já apresentados em Santos (2017), nossa intenção é mais uma vez demonstrar que a referida crise tem sido mal compreendida pela maioria das vertentes do ambientalismo, posto não se tratar de uma simples e hodierna casualidade do atual modelo de desenvolvimento econômico, mas de um fenômeno intrínseco ao capitalismo, surgido desde a gênese histórica desse modo de produção.

Primeiro, procuramos compreender o processo de Globalização, quais os sentidos atualmente atribuídos a esse momento histórico e geográfico e qual a sua natureza, salientando suas implicações ambientais. Depois de esclarecido seu nexo com a crise ambiental, procuramos realizar a crítica dos principais elementos discursivos atualmente presentes no ambientalismo, observando o caráter político-econômico da crise e suas raízes histórico-concretas.

\footnotetext{
$\overline{5}$ Professor Adjunto do Departamento de História da Universidade Federal Rural de Pernambuco (UFRPE), e-mail: otavio.augusto@ufrpe.br.
} 


\section{A GLOBALIZAÇÃO COMO FÁBULA}

O que é a Globalização? Abrangente por tudo o que evoca, este termo suscita inúmeras concepções, muitas delas notadamente divergentes, chegando a acumular nos dias atuais uma quantidade extremamente diversa de debates, teorias e publicações acadêmicas. As interpretações são tão diversas que qualquer tentativa de classificá-las com base em poucos critérios constitui trabalho árduo, extrapolando o escopo e os limites de um texto como este. Para o senso comum e para diferentes espectros da grande mídia, contudo, a Globalização alude a um conjunto muito claro de ideias, dinâmicas econômicas e projetos políticos. Tais ideias referenciam-se nos espetaculares progressos das comunicações observados e atualmente experimentados nos mais diferentes cantos do mundo, na intensa expansão do comércio e sua financeirização, bem como no processo de fragmentação e translocalização internacional da produção, fenômenos reais que passaram a ser tratados como inevitáveis a partir do último quartil do século XX.

Quase sempre associada à construção de uma ordem mundial pacífica, o termo também surge na esteira da construção de uma governança mundial após a Segunda Guerra, através da consolidação de diferentes organismos multilaterais, surgidos sob o fito de garantir tal governança em suas mais diversas áreas. A ideia ganha novos contornos quando da hegemonização de uma agenda econômica que, ao apregoar os limites teóricos e práticos de uma economia nacional calcada em seu mercado interno, sugere uma ordem mundial próspera para todos aqueles que aderem entusiasticamente suas prescrições político-econômicas. Neste sentido, o referido termo sempre esteve associado à Organização Mundial do Comércio $(\mathrm{OMC})$ e à toda sorte de acordos políticos e econômicos bilaterais ou multilaterais que viabilizam e ordenam o fluxo financeiro, de mercadorias e de "pessoas", a despeito de seus países e continentes de origem, criando o "mercado mundial". Aceitar a Globalização é, segundo esta concepção, estar aberto à valores sociais universalmente aceitos, com os quais floresce a liberdade econômica e o avanço tecnológico, condições essenciais tão "desprezadas" em economias fechadas, como a que marcou a experiência soviética, a dos demais países comunistas e dos países onde vicejou qualquer matriz de pensamento econômico voltado ao desenvolvimento nacional.

\footnotetext{
${ }^{6}$ Sabe-se que o fluxo financeiro e de mercadorias sao evidentemente prioritários. Apesar de sua intensificação nos ultimos 50 anos, o fluxo de pessoas sempre teve como mediação restritiva os fechamentos de fronteiras, a xenofobia e os nacionalismos que, paradoxalmente, persistiram a ascensão dessa perspectiva enganosa de Globalização.
} 
Globalizar-se implica, por fim, abrir-se para as mercadorias e os valores que transitam "livremente" nessa esfera de comunicação global, no âmbito da qual as sociedades esboçam o ideal antigo de comunhão universal, para o qual o fluxo interminável de informações, a aceleração do tempo e o encurtamento das distâncias são imprescindíveis. Contudo, conforme Milton Santos (2008) já havia advertido, essa concepção mais difundida é, pois, uma fábula, sustentada pelos que mais se beneficiam desse estado de coisas. Trata-se de um engodo que escamoteia desigualdades e rupturas de culturas e ecossistemas, pois, em vez de nos direcionarmos para a tal ordem mundial pacífica, estamos, na verdade, convivendo disfarçadamente e ainda recrudescendo problemas sociais e ambientais de séculos passados, tais como a fome e mortalidade infantil.

\section{A REALIDADE DA GLOBALIZAÇÃO E SUAS IMPLICAÇÕES AMBIENTAIS}

Milton Santos (2008) ainda sentencia: a Globalização se impõe como uma fábrica de perversidades, proporcionada por um impressionante sistema unificado de técnicas, uma percepção do tempo cada vez mais homogênea, a constituição de uma mais-valia universal como motor único e um conhecimento extensivo e profundo do planeta, constituindo um novo período na história do capitalismo que é ao mesmo tempo uma crise.

Sousa Santos (2005) também possui uma visão crítica da Globalização. Para o sociólogo português, ela corresponde a um campo de conflitos, para os quais concorre interesses hegemônicos e subalternos, e que possui um componente 'descritivo' e outro 'prescritivo'. O que há de prescritivo, segundo o autor, corresponde ao vasto conjunto de ideias e regras amparadas em um "consenso hegemônico". O consenso a que o autor se refere é o de Washington, cuja função foi instituir, desde a década de 1980, as políticas de desenvolvimento no interior do sistema econômico mundial. A Globalização, segundo Sousa Santos, seria o seu resultado.

Ianni (1997), por outro lado, compreende que a Globalização é muito anterior ao referido consenso. Segundo sua concepção, o capitalismo esboça, desde seus primórdios, uma tendência aberta à expansão global. Essa tendência se intensifica no século $\mathrm{XX}$, adquire novos contornos com o término da Segunda Guerra Mundial, mas se consolida frente às grandes transformações históricas do final do século XX, quando da vitória do bloco capitalista sobre o comunista, tendo como marco histórico a Queda do muro de Berlim. Assim, para este autor, o fim do socialismo real encerra uma época na medida em que reorganiza as cartografias 
geopolíticas, redefinindo o papel do Estado e a marcha da economia mundial. A Globalização, então, caracteriza-se por uma internacionalização da produção e das finanças, por uma nova divisão internacional do trabalho, uma nova competição por recursos naturais e, sobretudo, por uma redefinição das estruturas de Estado, que deixa de ser concebido como aparato de proteção da economia nacional e da promoção do bem-estar social, para ser um mediador entre a economia nacional e a mundial. Neste sentido, Ianni (2007, p. 11) conclui que

\begin{abstract}
A Globalização do mundo expressa um novo ciclo de expansão do capitalismo, como modo de produção e processo civilizatório de alcance mundial. Um processo de amplas proporções envolvendo nações e nacionalidades, regimes políticos e projetos nacionais, grupos e classes sociais, economias e sociedades, culturas e civilizações. Assinala a emergência da sociedade global, como uma totalidade abrangente, complexa e contraditória. Uma realidade ainda pouco conhecida, desafiando práticas e ideias, situações consolidadas e interpretações sedimentadas, formas de pensamento e voos da imaginação.
\end{abstract}

Harvey (2006) problematiza a concepção de que a Globalização constitui um novo momento histórico, mas reconhece que tem a ver com as transformações recentes na economia política do capitalismo. Este autor afirma que é possível compreender a Globalização como um processo, como uma condição e como um projeto político. Segundo seu ponto de vista, as características desse do que se convencionou chamar de Globalização estão presentes na própria Geografia histórica do modo de produção capitalista, desde sua constituição histórica. Contudo, é necessário discernir um conjunto de importantes e recentes mudanças, tais como: a desregulamentação financeira; as profundas e incessantes inovações tecnológicas; as mudanças na produção e consumo de informações, bem como nos sistemas de mídia; e um maior fluxo de informações e pessoas.

Arrighi (1996) parecia possuir uma visão semelhante. Para este autor, uma mudança fundamental ocorreu no último quartil do século XX na configuração espacial dos processos de acumulação capitalista. Na década de 1970, a tendência predominante era a do deslocamento dos processos de acumulação desde as regiões ricas para as regiões mais pobres do planeta. A partir de 1980, entretanto, uma nova transformação tem ocorrido nos países ricos, no arco de um processo de complexificação e aumento da mobilidade geográfica do Capital. Cabe lembrar que, segundo Arrighi (1996), o capitalismo havia se desenvolvido com base em um moderno sistema interestatal, do qual uma nação sempre exerceu hegemonia perante as demais.

Arrighi (1996) afirmava que o momento atual se caracteriza pela irrupção de um novo sistema interestatal de desenvolvimento do capitalismo, encabeçado pelos Estados Unidos da América, e que pressupõe a universalização de um modelo de produção e de 
consumo essencialmente desigual e extremamente impactante ao equilíbrio dinâmico dos ecossistemas terrestres. Seguindo esse viés, Porto-Gonçalves (2017), afirma que os atuais problemas ambientais advêm do modelo de desenvolvimento propalado pelo "sistema-mundo moderno-colonial". Na visão deste autor, a constituição histórica desse sistema se deu por meio de diferentes fases: uma primeira, marcada pela implantação da moderno-colonialidade; uma segunda, pelo surgimento do modelo de acumulação expansivo e imperialista baseado no amplo consumo de combustíveis fósseis; uma terceira, calcada numa forte presença do Estado na garantia desse modelo de acumulação; e uma última, marcada pela "globalização neoliberal". O sistema-mundo moderno-colonial constitui, assim, uma opção civilizatória que tende a desenraizar o homem de seu entorno, ocasionando o seu "des-envolvimento", sendo ele hoje difundido e dialeticamente defendido em todos os lugares do mundo, inclusive por algumas vertentes do movimento ambientalista.

Seguindo algumas das ideias propostas por Harvey (2006) e por Porto-Gonçalves (2017), acreditamos que a Globalização constitui um novo momento histórico e geográfico do modo de produção capitalista, sistema esse que é essencialmente expansivo e tende a alcançar todo o globo. Não se trata de um momento inteiramente novo, mas que implica, na verdade, uma nova dinâmica no interior de uma estrutura social e econômica estabelecida desde muito tempo. Por isso consideramos que as implicações ambientais decorrentes dessa Globalização não são exclusivas desse momento, porque surgidas do próprio modo de produção capitalista, e desde sua gênese histórica.

\section{HÁ UMA CRISE AMBIENTAL DE ESCALA GLOBAL?}

Se a Globalização constitui a mais recente e complexa etapa do processo de expansão mundial do modo de produção capitalista, os problemas ambientais resultantes são também mundiais? Pode-se realmente falar de uma crise ambiental de escala global? Conforme já problematizamos em Santos (2017), a ideia de uma crise ambiental tem sido repetida em diferentes contextos, tornando-se hoje um axioma, defendido até pelos principais agentes do processo global de acumulação do capital. Trata-se de uma ideia poderosa que, a despeito de suas especificidades espaciais e temporais, tem fustigado a ação de governos, de organizações não-governamentais e de algumas expressões do movimento ambientalista.

Desde a irrupção da mais recente crise do capitalismo, aliás, a ideia de crise tem sido redimensionada, ganhado novos elementos. A luta contra os fatores de sua intensificação, tais 
como a tentativa de redução da emissão de poluentes atmosféricos, tem fundamentado cada vez mais as atuais estratégias de ação política com perspectivas universais. Esse combate é realmente abrangente e resiste, inclusive, a atual e surpreendente escalada conservadora, cuja maior platitude é negar a existência de alguns dos mais reconhecidos problemas ambientais, tais como o aquecimento global. A despeito dessa importante tendência, diferentes atores hoje consideram verdade irrefutável a existência de uma crise ambiental de escala global.

Não há problema ambiental que não seja atualmente tratado como sintoma de processos essencialmente globais. Neste sentido, a própria força da imagem da Globalização é reforçada pela ideia de crise. Não haveria mais nada efetivamente localizado. A poluição atmosférica atualmente emitida, sobretudo, nos EUA e na China intensifica o aquecimento global e a temperatura dos oceanos, ocasionando o branqueamento dos corais no Pacífico. Uma embalagem de plástico descartada no Caribe será carregada pelas correntes marinhas e ingerida por algum mamífero marinho a milhares de quilômetros de distância. Os problemas ambientais são "problemas-mundo". Não por acaso, as soluções à crise são na maioria das vezes pensadas a partir de esforços supralocais. Todos os eventos internacionais que marcaram a construção da agenda ambientalista constituem o esforço de construção de uma governança global, que vise auxiliar no ordenamento das relações sociais e da exploração dos recursos naturais, muitas vezes à revelia das especificidades políticas e econômicas nacionais. As principais entidades e acordos ambientais surgiram por iniciativa de grandes organismos multilaterais, tais como o Programa das Nações Unidas para o Meio Ambiente (PNUMA).

\section{SENTIDOS DA CRISE AMBIENTAL}

Globalização e crise ambiental são ideias interdependentes e igualmente difíceis de se compreender. Ainda mais difícil é determinar quem os produz. Está claro que a Globalização é o resultado do atual estágio da acumulação capitalista. Mas, e a crise ambiental? Segundo a concepção mais difundida e atualmente aceita, sejam pelos diferentes prismas do ambientalismo, como pelos agentes do sistema-mundo, os problemas ambientais percebidos e vividos por diferentes grupos sociais no mundo inteiro constituem apenas resultados indesejados do modelo de desenvolvimento resultante da Globalização. Correspondem a subprodutos desse modelo, que podem ser evitados pontualmente por meios de mudanças tecnológicas e de inovações nos processos produtivos. 
Não cessam de surgir soluções alternativas, desde os sistemas preventivos de gestão ambiental às tecnologias para recuperação de áreas já degradas, muitas delas vistas efetivamente como deus ex machina na resolução dos problemas. As descobertas da ciência natural e a criação de novas tecnologias figuram enquanto únicas referências a partir das quais as fórmulas são criadas. O "naturalismo" e o "tecnicismo" tornaram-se princípios ordenadores dos discursos ecológicos, relegando para segundo plano aspectos políticos (MORAES, 2002). No transcurso dos últimos 50 ou 60 anos, essas tendências marcaram as correntes hegemônicas do pensamento ecológico, muitas das quais apoiadas numa razoável crítica ao produtivismo e ao consumismo, e repletas de soluções aos diferentes problemas ambientais, mas sem considerar sua vinculação essencial com o sistema capitalista.

Em que pese todos os avanços obtidos nas últimas décadas com o desenvolvimento da ciência e da tecnologia, sobretudo no que concerne ao aumento da qualidade de vida, mas também às vitórias que a humanidade vêm conhecendo face às suas próprias limitações naturais, não se pode esperar que a ciência e a tecnologia terão respostas para tudo, inclusive para os dilemas de ordem política que o próprio modelo de desenvolvimento resultante da Globalização vem ocasionando. Enquanto pouco se avança na construção da tão aclamada "sustentabilidade", a crise que se pretende combater continua a se intensificar e a se expandir pelo planeta, sobretudo nos países pobres e colonizados, a despeito da existência de conhecimentos e de técnicas para enfrentá-la.

Acreditamos que essa interpretação da crise é, sem sobra de dúvidas, extremamente acrítica e, em certa medida, um tanto perversa, pois realiza um evidente obscurecimento das raízes histórico-concretas dos problemas ambientais. E a elaboração de soluções falaciosas e pretensamente salvadoras, complacentes com a ordem atual, tais como aquelas ancoradas no raso conceito de "desenvolvimento sustentável", de nada ajudam a elucidar a questão. Pelo contrário, permite sua apropriação pelas grandes empresas multinacionais, que as reduz a meros discursos, muitos dos quais postos à venda como mercadorias. A ideia de crise e o remédio do desenvolvimento sustentável têm sido cada vez mais apropriados e difundidos pelos agentes do sistema-mundo no mercado das soluções redentoras.

\section{CRÍTICA DO ECOLOGISMO ACRÍTICO}

Medeiros \& Barreto (2013), em texto onde defendem uma ética ambiental materialista, chamam de "ecologismo acrítico", as vertentes do pensamento ecológico que se 
distinguem "[...] pela pretensão de superar os problemas ambientais no interior da formação social em que vivemos, a sociedade regida pelo capital” (Ibidem, p. 318). Poderíamos dizer que o ecologismo acrítico comunga da supracitada interpretação da crise, segundo a qual os problemas ambientais correspondem a falhas reversíveis no atual modelo de produção de riquezas.

Conforme já apontamos em Santos (2017), mesmo tendo realizado uma pujante crítica do mundo moderno, o ecologismo acrítico apoia maior parte de seus discursos e práticas em um paradigma de ciência essencialmente dualista, que põe em lados opostos o homem e a natureza. Trata-se, contudo, de um dissenso que limita o alcance da compreensão e da ação transformadoras, e que apenas fortalece a crença moderna da superioridade do homem frente a natureza, convicção com a qual os agentes do sistema-mundo construíram os próprios quadros de desarranjo ecológico. Isto é, admitir essa visão contribui com a progressiva ruptura do homem em relação ao seu entorno.

Outra característica importante presente no ecologismo acrítico, conforme já descrevemos, é a de supor que os avanços tecnológicos têm sido capazes de garantir a contínua expansão da produção sob uma economia de recursos cada vez maior. Sabe-se que, de fato, por sua própria dinâmica, o sistema capitalista tende a dar impulso a ganhos através de uma maior eficiência, produtividade e intensidade do trabalho. E isso, em alguns casos, implica em um consumo menor de recursos naturais e energéticos. Esses são, inclusive, alguns dos aspectos que caracterizam o que Marx (1974) chamou de "desenvolvimento das forças-produtivas". Contudo, sabe-se também que o objetivo precípuo presente na tendência pela eficiência não é a economia de recursos, mas a possibilidade de ganhos em forma de lucros. O que, trocando em miúdos, significa maior exploração do trabalho (BARRETO, 2016).

Crítico ao otimismo tecnológico e partindo de uma perspectiva marxiana, Barreto (2016) afirma que a generalização dos processos de maior produtividade reduz o tempo de trabalho necessário, o que significa perda de valor, posto que o valor da mercadoria corresponde sempre ao tempo médio de trabalho socialmente necessário. Como a produção pressupõe a obtenção sempre maior de lucro, não resta outra alternativa senão expandir o consumo, a demanda por recursos e de trabalho, aumentando o valor incorporado. Em outras palavras, a despeito da possibilidade de economia de recursos, o capitalismo não sobrevive sem expandir a produção e consumir parcelas cada vez maiores de recursos e energia. 
O capitalismo age desgovernadamente sobre a superfície terrestre, transformando todo recurso em mercadoria, desarranjando progressivamente o equilíbrio energético dos ecossistemas. E no atual momento histórico e geográfico da Globalização essa tendência ao uso crescente de recursos e energia tomou uma dimensão colossal. Isso é o que torna essencialmente global os problemas ambientais de hoje. Mas longe de pensar na crise ambiental como um resultado inesperado do modelo de desenvolvimento atualmente hegemônico, algo reversível dentro das condições estruturais do presente, deve-se compreendê-la como uma expressão recente das contradições inerentes ao próprio sistema capitalista.

\section{A NATUREZA DA CRISE AMBIENTAL}

Apesar das diferentes dinâmicas e configurações político-econômicas, o sistema capitalista mantém desde sua gênese histórica uma estrutura a partir da qual tem garantido sua reprodução. Os mais importantes elementos dessa estrutura são: o permanente processo de espoliação; a exploração do trabalho; e, por fim, a necessidade de reprodução ampliada. Qualquer leitura efetivamente crítica a propósito da Globalização e da crise ambiental deve, via de regra, partir da real compreensão desses elementos estruturais.

O sistema capitalista não existiria sem um processo de espoliação inicial, a qual Marx preferiu chamar de "acumulação primitiva" (MARX, 1974). Essa acumulação, por sua vez, possui dois fatores históricos: o saque colonial e o sistemático encerramento das propriedades comunais que se deu de forma mais evidente desde o século XVI até o século XVIII (HUBERMAN, 1983). A colonização permitiu o enriquecimento de uma classe de comerciantes que mais tarde se tornaria a burguesia, e o processo de apropriação das terras agrárias durante mais de três séculos permitiu o surgimento da propriedade privada capitalista e do operariado. Essa última classe adveio das grandes levas de indivíduos que foram sendo despojados das condições materiais de produção, tendo sido forçados a migrar para as cidades, onde foram integrados enquanto força de trabalho alienada na produção capitalista de mercadorias.

Em vez de sublinhar apenas um momento na história, esse processo inicial de espoliação permanece até os dias atuais, pois, em sua dinâmica geográfica, as relações de produção capitalistas ainda hoje se integram e depois dilapidam os modos de produção regionais, desalojando os homens de suas terras, dos seus laços territoriais e de seus diferentes 
modelos de metabolismo com a natureza. Em seu lugar, ela implanta uma nova relação com a natureza, mais utilitarista, da qual o que vale é a obtenção do lucro, a despeito de todo equilíbrio dinâmico que sustenta os ecossistemas. Harvey (2004) chama de "acumulação por espoliação" essa característica presente na geografia histórica do capitalismo, cuja marca é a permanente transformação de bens não-mercantis em mercadoria.

A classe trabalhadora surgida dos inúmeros desalojados, não tendo outras posses além de sua força de trabalho para oferecer em troca dos meios de subsistência, foi e continua sendo obrigada a inserir-se enquanto massa de trabalho alienada na produção de mercadorias, em uma lógica da qual a obtenção de lucro é fundamental. A progressiva exploração dessa classe é, pois, fundamental à reprodução de todo o sistema. Toda a geopolítica do capitalismo está calcada nas possibilidades de crescimento dessa exploração, pois é em busca de uma força de trabalho controlada que a produção se translocaliza.

A formação dessa massa desalojada e trabalhadora caracteriza-se, em última instância, pela separação entre o homem e as condições materiais de reprodução de sua vida. O trabalhador no modo de produção capitalista é um ser desgarrado da natureza. Sua existência é parcial e desterritorializada, pois seu corpo, seu tempo e seu entorno não lhe pertencem. O mesmo se pode dizer do capitalista, sua relação com a natureza é também desterritorializada, pois mesmo detendo a posse dos meios e condições materiais de produção - o que, certamente, fornece-lhe melhores perspectiva de intercâmbio com a natureza -, essa classe tem para com o mundo uma relação utilitarista, de domínio, meramente econômica.

A tendência à reprodução ampliada, por fim, impõe ao capitalista, ao trabalhador e à natureza uma dinâmica de crescimento que foge a qualquer controle. Ela obriga o capitalista a explorar cada vez mais o trabalhador para se manter e o faz conceber a natureza como mais um insumo. Onde ainda resiste outras formas de propriedade dos bens naturais, ela mercantiliza as relações e põe, conforme resumiu Smith (1988, p. 94), "uma etiqueta de preço em qualquer coisa". Nesse processo, desde a terra, o ar, as águas, as florestas e os animais são transformados em mercadoria, e sua apropriação e uso passam a ser regrados segundo normas de mercado. Com os avanços científicos nas áreas da genética e da biotecnologia, até os códigos genéticos são também objeto de apropriação. A possibilidade de sua manipulação na criação de seres vivos inteiramente novos e resistentes a diversos tipos de adversidades ambientais constitui uma nova frente de produção do valor. 


\section{CONSIDERAÇÕES FINAIS}

A Globalização é de fato uma fábrica de perversidades, porque corresponde ao atual estágio do processo de acumulação capitalista. E se a crise ambiental contemporânea deita suas raízes nesse processo, então Globalização e crise ambiental são faces de uma mesma moeda.

Longe de corresponderem a fenômenos hodiernos, do qual podemos precisar e enfrentar à revelia do sistema capitalista, Globalização e crise ambiental são aspectos desse sistema, têm seus fundamentos ligados a seus elementos estruturais. Neste sentido, não se pode compreendê-los sem levar em conta esse modo de produção e não se pode confrontá-los e superá-los sem fazer frente às relações sociais que lhe dão sustentação.

\section{REFERÊNCIAS}

ARRIGHI, G. O longo século XX: dinheiro, poder e as origens de nosso tempo. Rio de Janeiro: Contraponto; São Paulo: Editora Unesp, 1996.

BARRETO, E. Marx contra o otimismo tecnológico: economia "imaterial" desmistificada e desdobramentos para as questões ambientais. Nova Economia, v. 26, n. 1, 8 ago. 2016.

HARVEY, D. O novo imperialismo. São Paulo: Loyola, 2004.

Espaços de esperança. 2.ed. São Paulo: Loyola, 2006.

HUBERMAN, L. História da riqueza do homem. 19.ed. Rio de Janeiro: Zahar, 1983.

IANNI, O. A sociedade global. 5.ed. Rio de Janeiro: Civilização Brasileira, 1997.

A era do globaritarismo. 9.ed. Rio de Janeiro: Civilização Brasileira, 2007.

MARX, K. O Capital: crítica da economia política (livro 1). Rio de Janeiro: Civilização Brasileira, 1974.

MEDEIROS, J. L; BARRETO, E. S. Lukács e Marx contra o “ecologismo acrítico": por uma ética ambiental materialista. Revista Economia e Sociedade, v. 22, n. 2 (48), p. 317-333, 2013.

MORAES, A. C. R. Meio ambiente e ciências humanas. 3.ed. São Paulo: Hucitec, 2002.

PORTO-GONÇALVES, C. W. A globalização da natureza e a natureza da globalização. 7.ed. Rio de Janeiro: Civilização Brasileira, 2017. 
SANTOS, O. A. A. Algumas notas a uma compreensão crítica da chamada 'crise ambiental'. Germinal: Marxismo e Educação em debate, v. 9, n. 2, p. 195-210, 2017.

SMITH, N. Desenvolvimento desigual: natureza, capital e a produção de espaço. Rio de Janeiro: Bertrand Brasil, 1988.

SOUSA SANTOS, B. Os processos da Globalização. In: SOUSA SANTOS, B (Org.) A Globalização e as ciências sociais. 3.ed. São Paulo: Cortez, 2005. 


\title{
A VALORAÇÃO DO CAPITAL NATURAL FRENTE AO MERCADO, AO ESTADO E À SOCIEDADE
}

\author{
Ana Karoline de Carvalho Silva ${ }^{7}$ \\ Assíria Marielle da Silva Dantas ${ }^{8}$ \\ Ana Márcia Moura da Costa ${ }^{9}$
}

\section{NOTAS INTRODUTÓRIAS}

Nas últimas décadas, os problemas decorrentes da crise econômica em curso podem representar um momento único para repensar os rumos que a sociedade vem tomando em relação ao capital financeiro, e as variações existentes a partir deste. Neste trabalho, o conceito de capital natural utilizado considera todos os fluxos de benefícios tangíveis e intangíveis provenientes de todos os recursos naturais que são utilizados e modificados pela ação antrópica. O capítulo tem por objetivo discutir a importância do capital natural, sua valoração, e os papéis exercidos pelo Estado, mercado e sociedade em relação ao uso deste capital, promovendo uma discussão da relevância do capital natural para o sistema capitalista.

\section{A RELAÇÃO ENTRE O CAPITAL NATURAL E AS OUTRAS VARIAÇÕES DE CAPITAL}

O capital é um estoque que produz bens e serviços que atendam ao futuro, de maneira a prover riqueza e bem-estar para a sociedade, tornando-se indispensável para a manutenção desta (HARTE,1995. HINTEBERG et al, 1998). Para Costanza et al. (1997) esse

\footnotetext{
${ }_{7}^{7}$ Bacharela em Geografia e Mestranda em Desenvolvimento e Meio Ambiente - Prodema pela Universidade Federal de Pernambuco - UFPE, e-mail: karolcarvalho869@gmail.com.

8 Licencianda em Geografia pela Universidade Federal de Pernambuco - UFPE, e-mail: dantasassiria@gmail.com.

${ }^{9}$ Mestranda pelo Programa de Pós-graduação em Desenvolvimento e Meio Ambiente - PRODEMA, da Universidade Federal de Pernambuco - UFPE, e-mail: anamouracosta08@gmail.com.
} 
estoque pode ser tanto de matéria, quanto de informação disponível em determinado momento da história, e isto possibilita a existência de variações do capital, como é o exemplo do capital natural (água, solo, florestas, minerais, atmosfera etc.).

O capital natural é constituído pelos bens naturais existentes que geram um fluxo de bens e serviços que a sociedade converte em produtos úteis de forma a manter ou elevar o seu bem-estar no presente e futuro. Como, por exemplo, as populações de peixes que permitem o fluxo de pescado em regiões, as florestas que possibilitam o fluxo de madeiras e seus derivados, o estoque de petróleo que permite o fluxo de óleo e derivados do mesmo, e as terras agriculturáveis que possibilitam o fluxo da produção de alimentos (DALY, 1991; MACDONALD, 1999). Segundo O'Connor (1999) o conceito do capital natural é híbrido (estruturado pela economia e ecologia) porque demonstra que é necessária uma qualidade ambiental para que se tenha, posteriormente, o bem-estar social e a sustentabilidade econômica a longo prazo.

Desta maneira, entende-se que a totalidade dos recursos oferecidos pelo ecossistema terrestre é quem suporta o sistema econômico, os quais contribuem direta e indiretamente para o bem-estar humano. Essa definição explicitamente considera a ideia de que o sistema econômico é um subsistema de um sistema maior, que o sustenta e que lhe fornece os meios necessários para sua expansão (COSTANZA \& DALY, 1992). Sua importância é inquestionável, uma vez que suporta toda atividade humana e aprovisiona, com bens e serviços, o mundo que nos mantém vivos.

Cientes da discussão acerca do capital natural, tornam-se relevantes outras variações do capital (cultural, manufaturado e cultivado) que influenciam e são influenciadas diretamente por este. São estas:

a) O Capital Cultural (cultural capital) é a visão de mundo da sociedade, seus valores, crenças, e suas preferências sociais (respeitadas as diversidades culturais), ética e filosofia ambiental, seu saber ecológico tradicional e suas interpretações. Estes fatores são responsáveis como meios para as adaptações da interação humana com o ambiente natural e de qual maneira devem modificá-lo na busca de riqueza e bem-estar (BERKES \& FOLK, 2000 apud DENARDIN \& SUTZBACH, 2002;

b) Capital Manufaturado (human-made capital) são recursos materiais produzidos pelas atividades humanas, tais como máquinas, estradas, moradias, alimentos, etc. É necessário para o pleno funcionamento do sistema econômico, produção de capital manufaturado, por meio da atividade econômica. Porém causa alterações no capital 
natural, ambiente físico e biológico que é produzido por meio da movimentação econômica e dos avanços das tecnologias através de interações entre os capitais natural e cultural (BERKES \& FOLK, 2000 apud DENARDIN \& SUTZBACH, 2002);

c) Capital Cultivado (cultivated capital) que é uma variação também híbrida, que combina capital manufaturado e capital natural para obter determinados bens ou serviços, tais como alimentos, madeiras, e outras matérias-primas que são vitais para o bem-estar da sociedade. Cabe destacar que a grande diferença entre o capital natural e o capital cultivado se encontra em o primeiro constituir-se de um "ecossistema único" (ex.: floresta tropical), e o segundo ser um "ecossistema repetível" (ex. plantações de milho, trigo, etc.). Dessa forma, manipulado pelo homem para suprir suas demandas (DENARDIN \& SUTZBACH, 2002).

Assim, todos dependem primariamente da existência do capital natural, para serem produzidos e reproduzidos. Estes capitais influenciam no capital natural ao passo que também são influenciados por ele. Esse entendimento denota o caráter de dependência que a sociedade humana tem deste capital a ser considerado o primeiro (ANDRADE e ROMEIRO, 2009; DENARDIN \& SUTZBACH, 2002). Com essa compreensão, partiremos da ideia que o capital natural não pode ser substituído, haja vista a impossibilidade de produzir ou reproduzir algo que não tenha, por base no mínimo, algum insumo da natureza.

\section{O DESAFIO DAS POLÍTICAS DE VALORAÇÃO AO CAPITAL NATURAL}

Com o desenvolvimento da sociedade moderna, a concepção equivocada de que o capital natural era infindável ganhou cada vez mais proeminência, principalmente em relação ao uso desenfreado desses recursos. A valoração deste capital na sociedade ainda não é uma prioridade, pois a consequência foi a criação de um sistema que privatiza os ganhos econômicos e socializa as perdas ambientais -"externalidades". Hoje, temos uma economia que rompe os limites do capital natural, seja a curto ou a longo prazo, e caso continue nessa corrida o resultado será o esgotamento desses recursos (STRUMPF, 2013).

Todavia, para um emprego adequado, a fim de desenvolver alternativas para políticas públicas com ênfase na valoração do capital natural, se faz necessário repensar em como valorar esses recursos naturais. Tendo isso como base, duas perspectivas apresentam um grande destaque: a valoração econômica (valor de troca) e a valoração ecológica (valor de uso), porém, dialeticamente, ambas contribuem para o reducionismo. Sendo assim, pode-se 
dizer que para alcançar de fato as políticas públicas, se faz necessário repensar a forma de valoração do capital natural, necessitando assim, de uma visão mais aprofundada, de forma a considerar critérios que por vezes são desconsiderados, mas fazem toda a diferença para a formação de políticas efetivas que tentem equilibrar minimamente os antagonismos da relação entre a sociedade e a natureza.

No que tange à valoração econômica, Andrade (2010) apud Reyes (2018) coloca que os métodos de valoração em geral não consideram a complexidade e diversidade dos bens e serviços fornecidos pelos ecossistemas, com isso, subestima seu valor agregado, ou seja, contrapõe a ideia de valoração ecológica. Schwarz (2012) por sua vez, aponta que deve ser repensado o critério de avaliação, por meio de uma valoração multicritério. De acordo com essa avaliação, a crítica é feita em relação aos pressupostos nacionalistas da análise econômica convencional aplicada ao meio ambiente, como também a própria contabilidade energética, proposta por alguns ecologistas mais ilustres. A avaliação multicritério não aceita, em síntese, as premissas de valoração de bens e serviços do ambiente, justamente por defender que os processos biofísicos são bastante complexos, por isso, não podem ser apreendidos por métricas unidimensionais.

\begin{abstract}
A abordagem característica da avaliação multicritério não consiste em identificar uma solução ótima, como acontece com a análise monetária convencional ou a contabilidade ecoenergética (valoração econômica e valoração ecológica), mas sim em chegar a valorações satisfatórias, tendo em conta a natureza muitas vezes contraditória dos critérios retidos para análise, a diversidade dos interesses e das perspectivas muitas vezes conflitantes das partes envolvidas, bem como o tipo de informação que elas possuem. (SCHWARZ, 2012, grifo nosso)
\end{abstract}

Funtowicz e Ravetz (1994) apud Schwarz (2012) coloca que essa metodologia é combinada por uma lógica intrínseca, da epistemologia com a governação, a ponto de reconhecer a interdependência entre o universo do conhecimento e o universo da ação política, com isso, é atribuído o mesmo grau de importância no que se refere à qualidade dos recursos obtidos. Por essa razão, a avaliação multicritério envolve a participação ativa dos parceiros sociais, revelando a natureza do processo interativo e dinâmico. Além disso, em meio a essa abordagem o diálogo ganha destaque, pois não se baseia na verdade abstrata, pelo contrário, os critérios de qualidade adotados pressupõem princípios éticos, que nesse caso participam do diálogo.

Em meio a esse panorama, por mais que haja uma ampla discussão no que se refere à forma (adequada) de valoração do capital natural, que se mostra como uma necessidade emergencial, existem atores que contribuem para esse arranjo segundo suas intencionalidades, são eles: do setor financeiro, as empresas e o setor público. 
Em 2012, na Conferência das Nações Unidas para o Desenvolvimento Sustentável, conhecida como Rio+20, foi lançada a Declaração do Capital Natural, declaração do setor financeiro convocando o setor público e o setor privado para unir forças em prol do capital natural, valorizando-o quanto aos pontos de vista econômico, ecológico e social, a fim de trabalhar rumo a economia verde. No documento proposto, o desenvolvimento de ferramentas adequadas de valoração e gestão de riscos por parte do setor financeiro foram os primeiros pontos a serem tratados. Todavia, é uma ação que exige o envolvimento e comprometimento de mais agentes, tanto é que em declaração, o setor financeiro afirmou:

Como membros do setor financeiro, nós nos consideramos partes interessadas chave nas futuras discussões sobre valoração e proteção do Capital Natural e reconhecemos que temos um papel chave nas reformas necessárias para criar um sistema financeiro que reporta e, em última instância, considera o uso, a manutenção e a restauração do Capital Natural na economia global. Entretanto, necessitamos agir alinhados com o governo e com o apoio de legislação e regulamentação apropriadas (EAESP, 2014).

$\mathrm{Na}$ Declaração, alguns apontamentos são feitos no que diz respeito à ação governamental, de modo que venha regularizar e incentivar o setor privado para a valoração e maior proteção do Capital Natural. São feitas exigências na divulgação da natureza de sua dependência e impactos; relatórios transparentes com a informações qualitativas e quantitativas; medidas fiscais que ofereçam incentivos às empresas que integrem, valorizem e considerem o capital natural em seus negócios; assim como a implementação de acordos internacionais, que sirvam como requerimento de compras e gastos públicos contabilizando o capital natural (EAESP, 2014).

Ao reconhecer amplamente a necessidade de gerir de maneira eficiente os recursos naturais, um grupo de instituições renomadas internacionalmente, reunidas em uma coalizão, a Natural Capital Coalition, trabalhou na elaboração do Protocolo de Capital Natural em 2016. Este documento tem por objetivo auxiliar os gestores de negócios a terem uma referência confiável a ponto de realizar relatórios confiáveis e satisfatórios. Esses registros consideram pontos importantes como a inserção do Capital Natural como parte da lógica produtiva da empresa (CEBDS, 2017). De acordo com a Fundação Calouste Gulbenkian (2018), o Protocolo permite que qualquer empresa de qualquer setor econômico, possa contabilizar seu capital natural. Para isso, os gestores segundo essa iniciativa devem pautar suas ações a partir destas quatro fases: “"porquê', 'o quê' e 'como' contabilizar o capital natural e finalmente, na fase 'o que vem a seguir', explicar como é que os resultados podem ser integrados, com sucesso, nos processos de tomada de decisão”. Sendo assim, o Protocolo pode ser aplicado nas seguintes questões: planejamento estratégico, avaliação da cadeia de 
fornecedores, tomada de decisão em nível operacional, financeiro e legislativo e, por fim, reporte de indicadores não financeiros.

Em uma pesquisa recente, o Natural Capital Coalition (2017) apontou que $86 \%$ das empresas acreditam que as abordagens de capital natural irão promover uma melhor tomada de decisões. Através de uma revisão realizada, perceberam um aumento no número de organizações que realizam avaliações de capital natural desde 2013. Embora haja desafios busca-se gerir, valorar de maneira consciente os recursos naturais por meio dessas iniciativas que têm se mostrado positivas.

Mesmo com as iniciativas do setor privado a respeito da valoração do capital natural, é preciso pensar em ações conjuntas - setor privado, público e sociedade civil. Os riscos de uma má gestão do capital natural não trazem consequências apenas para uma parte envolvida, mas para uma região em si. No relatório do projeto TEEB - The Economics of Ecosystems and Biodiversity (CI, 2014), realizado pela organização privada Conservação Internacional, foi apontada a necessidade dessa iniciativa conjunta a fim de promover uma melhor valoração e monitoramento da Biodiversidade e Serviços Ecossistêmicos (BSE). O relatório coloca a integração setorial ou na cadeia de valor como fundamental para evitar a sobreposição de responsabilidades e falta de coordenação.

É imprescindível repensar a forma de valoração do capital natural, pois isso repercute na maneira de induzir a tomada de decisões através de políticas públicas. A valoração multicritério é uma alternativa, na medida em que se colocam questões como: o bem "A" pode valer mais que o bem "B", em função do critério " $X$ ", mas pode valer menos em função de outro critério "Y". Com base nisso, pode-se entender que nenhuma solução dentro dessa perspectiva é capaz de otimizar todos os critérios simultaneamente.

A avaliação multicritério não se limita, pois, a ampliar os factos e as dimensões relevantes no cálculo do valor dos bens e serviços ambientais: na medida em que envolve a participação ativa de um número alargado de parceiros sociais, ela revelase também como um processo de aprendizagem interativo e dinâmico (SCHWARZ, 2012).

Alinhado a esse viés, é preciso relacionar a valoração do capital natural com o desenvolvimento das sociedades. Paula (2005) coloca a gestão compartilhada como instrumento primordial para alcançar um alinhamento do tão sonhado desenvolvimento e as partes integrantes. $\mathrm{O}$ desenvolvimento defendido por ele exige protagonismo local, a começar pela sociedade civil, pois sem o interesse, envolvimento, comprometimento da comunidade local, nenhuma política de indução ou promoção de desenvolvimento alcançará êxito. Essas estratégias de planejamento e gestão compartilhada contribuem para o crescimento do capital 
humano e do capital social, a partir das possibilidades de empoderamento da população local, de forma a facilitar a boa governança, essencial para o desenvolvimento sustentável. É uma forma de repensar o padrão de relacionamento entre Estado, mercado e sociedade civil.

\section{OS DESAFIOS DO ESTADO NA REGULAÇÃO DO CAPITAL NATURAL E A PARTICIPAÇÃO SOCIAL NA TOMADA DE DECISÕES}

O Estado enquanto garantidor do bem-estar social, além de deter o papel de minimizar as desigualdades econômicas e sociais geradas pela reprodução espacial do modo capitalista de produção, possui o papel de administrar o "patrimônio natural" de seu território, ao passo que oferece condições para o crescimento econômico através do mercado, agente que bastante usufrui do capital natural para a produção de bens e serviços.

As formas de uso existentes para cada recurso natural se apresentam como fatores que influenciam diretamente nas estratégias de apropriação, uso e controle destes recursos pelo capitalismo, o qual necessita deles enquanto suporte e manutenção para sua estrutura, que se dá ao espacializar e territorializar o seu modo de produção (WHITACKER, 2015).

O solo, por exemplo, pode ter o uso estritamente ligado à produção ou à edificação, e esses usos por serem diferentes e estarem estabelecidos em locais diferentes, acarretam a valores diferentes à propriedade, que, por conseguinte, são adquiridas por pessoas com rendas distintas. Dessa forma, ambos os usos afetam diretamente este recurso, porém em graus diferentes, seja uso produtivo, tornando o solo empobrecido conforme o tempo e as técnicas empregadas (agricultura/agropecuária) ou uso enquanto suporte para edificações, puramente especulativo-imobiliário. São estratégias diferenciadas para apropriação, uso e controle.

Embora exerça relativa influência no mercado, o Estado atua em duas frentes sobre este, a fiscalização e a regulação. O mercado é responsável pela dinâmica entre bens e serviços, e atores privados (enquanto produtores), públicos (representado pelo próprio Estado, com suas empresas estatais), e sociais (consumidor) (SILVA e MARTINELLI, 2012). Ele precisa ser fiscalizado e regulado para que não sejam desenvolvidas práticas desarmônicas que o desajuste, e por consequência, venham a prejudicar os seus agentes econômicos e, principalmente, a sociedade.

A principal concepção adotada pelo Estado para a cautela com o capital natural e o desenvolvimento da sociedade, sem comprometer o sistema econômico vigente, é a de desenvolvimento sustentável. Desenvolvimento este "que permite às gerações presentes 
satisfazerem suas necessidades sem comprometer a capacidade das gerações futuras satisfazerem as suas próprias" (BRUNDTLAND, 1987, p. 24 apud ANDRADE e ROMEIRO, 2009, p. 8). Uma visão que representa um patamar de relação entre sociedade e natureza harmônico, mas que recebe diversas críticas de estudiosos da área ambiental em relação à forma como é implantada esse tipo de política de desenvolvimento dentro de um sistema com oportunidades e situações sociais e econômicas tão diversas como o sistema capitalista.

Guilherme Whitacker (2015) por exemplo, defende que esta ideia de desenvolvimento, ao ser discutida e amparada por órgãos governamentais, subsidia-se muitas vezes por pressões de grandes indústrias. Ou seja, um renovado modo de produção "limpo" legitimado por grandes indústrias, mas que continuam a concentrar não só a renda, mas também o próprio capital natural a partir de legislações que por si só excluem pequenas e médias empresas através de exigências beneficiadoras a grandes mercados. "[...] um modelo no qual a natureza é instrumentalizada para a comodidade daqueles que detêm os meios de produção e, a população em sua grande parte, sofre com os domínios gerados pela concentração e centralização" (WHITACKER, 2015, p. 7), justificando, assim, a concorrência e cooperação entre grandes negócios em detrimento de menores.

Quando levados em consideração os ciclos e crises do capitalismo, apenas os grandes investidores e as grandes empresas passariam a deter não apenas o controle das técnicas e tecnologias, mas também o controle sobre os territórios através da implementação de suas técnicas. Dessa maneira, a concepção de desenvolvimento sustentável seria uma concepção para mitigar futuras crises, uma nova roupagem para "mais do mesmo", em que a superexploração da natureza continuaria em voga.

E, se consideramos que as técnicas estão sob o controle daqueles que possuem os meios necessários à sua implementação, podemos escrever que o domínio exercido pelas agroindústrias, o domínio fundiário é, também, um domínio territorial. Pois são esses que possuem o domínio lato do território, e, quem tem controle sobre o território tem controle sobre o Estado. (WHITACKER, 2015, p.8, grifo nosso).

Como o Estado enquanto mediador de interesses, fiscalizador e regulador, também participa do mercado e depende diretamente deste para prover bens e serviços que não produz, ele se encontra numa via de mão dupla entre beneficiar o mercado, mantendo "boas relações" políticas e econômicas externas e internas que viabilizem seus investimentos, e de modo a podar este mesmo mercado exercendo sua soberania nacional e efetuando escolhas que, de fato, contribuam para o desenvolvimento nacional prioritariamente. 
Porém, retornando à ideia de Estado social, observamos que todas as conquistas relativas aos direitos sociais foram alcançadas a partir de participações sociais durante a história. "[...] a natureza do Estado ou a sua qualificação como social, ou de bem-estar, ou providência, é empurrada pela própria evolução material e coletiva, isto é, pela dinâmica das estruturas que configuram a sociedade e as suas interações. " (REIS, 2011, p. 28). Daí, faz-se importante a sociedade requerer, crescentemente, maior abertura e participação no processo das tomadas de decisões do Estado, para que este se efetive enquanto "Social", assumindo os interesses e necessidades gerais das diversas classes dispostas em seu território, e não de grupos seletos.

A consciência da sociedade com relação à necessidade de valoração do capital natural se faz necessária para uma melhor gestão desse patrimônio. Pois, é através da mobilização, de pressões sociais, acerca das tomadas de decisões do Estado sobre maior regulação da exploração desses recursos, que se torna viável uma efetiva participação pública e democrática, configurando assim, uma gestão participativa que vise ao bem-estar de todos (as) os (as) envolvidos (as).

Sob esse cenário de gestão participativa, é preciso considerar que não deve haver apenas uma parte engajada no que tange à valoração do capital natural e o desenvolvimento das sociedades como um todo. Deve haver uma interação sinérgica entre o setor público, o setor privado e a sociedade civil. Sem a participação conjunta na elaboração de políticas públicas que visem à valoração dos recursos naturais, apontando os critérios mais relevantes, caminharemos a passos lentos em direção ao desenvolvimento. Ou seja, valorar o capital natural por meio de uma gestão participativa, promovida principalmente através de uma ordem local, seja a curto ou a longo prazo, alcançará maior articulação e, consequentemente, melhores resultados na busca do desenvolvimento das sociedades.

\section{REFERÊNCIAS}

ANDRADE, D. C.; ROMEIRO, A. R. Capital natural, serviços ecossistêmicos e sistema econômico: rumo a uma "Economia dos Ecossistemas". XXXVII Encontro Nacional de Economia. Foz do Iguaçu: ANPEC, 2009, p. 16. Disponível em:

<https://core.ac.uk/download/pdf/6228551.pdf> Acesso em: 18 set. 2018

BERKES, F. \& FOLK, C. A systems perspective on the interrelations between natural, human-made and cultural capital. Ecological Economics, vol. 5, p. 1-8, mar.1992. Disponível em: < https://www.sciencedirect.com/science/article/pii/092180099290017M > Acesso em: Acesso em: 20 set. 2018. 
CEBDS-Conselho Empresarial Brasileiro para o Desenvolvimento Sustentável. O que é Capital Natural? 2017. Disponível em: 〈http://cebds.org/blog/o-que-e-capitalnatural/\#.W6vPo2hKjIX > Acesso em: 25 set. 2018.

CI - Conservação Internacional Brasil. TEEB para o Setor de Negócios Brasileiro Relatório final, 2014. Disponível em:<

http://www.mma.gov.br/publicacoes/biodiversidade/category/143-economia-dosecossistemas-e-da-biodiversidade.html?download=1083:teeb-para-o-setor-deneg\%C3\%B3cios-brasileiro-\%E2\%80\%93-relat\%C3\%B3rio-final > Acesso em: 25 set. 2018.

COSTANZA, R. Economia ecológica: uma agenda de pesquisa In. May, P. M \& Serôa da Motta, R. (org.)Valorando a natureza: análise econômica para o desenvolvimento sustentável. Rio de Janeiro: Campus, 1994.

, R. et al. Value of the world's ecosystem services and natural capital. Nature, vol. 387,p. 253-260, nov. 1997. Disponível em: < http://www.osara.org/darwin_2008/required/Costanza_etal1997.pdf $>$ Acesso em: 18 set. 2018.

, R.; DALY, H. E. Natural capital and susteinable development. Conservation Biology, v. 6, n. 1, 1992, p. 37-46. Disponível em: $<$ http://math.unife.it/lm.ecologia/Insegnamenti/management-degli-ecosistemi/materialedidattico/Costanza\%20and\%20Daly\%201992.pdf> Acesso em: 25 set. 2018.

DALY, H. E. A economia ecológica e o desenvolvimento sustentável (textos para debates, tradução de John Cunha Comerfort). Rio de Janeiro: Assessoria e Serviços a Projetos em Agricultura Alternativa, p. 21, 1991

DENARDIN, V. F.; SUTZBACH, Mayra Taiza. Capital natural na perspectiva da economia. Anais do I encontro da associação nacional de pós-graduação e pesquisa em meio ambiente e sociedade. Indaiatuba, São Paulo: 2002. Disponível em: < http://www.anppas.org.br/encontro/primeiro/encontro_trabalhos.html. > Acesso em: 18 set. 2018

EAESP-Centro de Estudos em Sustentabilidade. Declaração do Capital Natural. 2014. Disponível em: 〈http://www.gvces.com.br/declaracao-do-capital-natural?locale=pt-br > Acesso em: 25 set. 2018.

FUNDAÇÃO CALOUSTE GULBENKIAN. O capital natural e as empresas. 2018. Disponível em: <https://gulbenkian.pt/programas/gulbenkian-oceanos/plataforma-capitalnatural-azul/ > Acesso em: 25 set. 2018.

HARTE, Michael J. Ecology, sustainability, and environment as capital. Ecological economics, v. 15, n. 2, p. 157-164, 1995. Disponível em:< https://www.sciencedirect.com/science/article/pii/0921800995000437> Acesso em: Acesso em: 25 set. 2018.

HINTERBERGER, F., LUKS, F., SCHMIDT-BLEEK, F. Material flows vs. 'natural capital'; what makes an economy sustainable? Ecological Economics, v. 23, n.1, p. 1-14, 1997.

Disponível em: < https://www.sciencedirect.com/science/article/pii/S0921800996005551>

Acesso em: 27 set. 2018 
LAPA, R. P. Capital Natural: Entenda o que é e suas aplicações às empresas. 2017. Disponível em: <http://segurancatemfuturo.com.br/index.php/2017/07/26/capital-naturalentenda-o-que-e-e-suas-aplicacoes-as-empresas/>. Acesso em: 25 set. 2018.

MACDONALD, D. V.; HANLEY, N.; MOFFATT, I. Applying the concept of natural capital criticality to regional resource management. Ecological economics, v. 29, n. 1, p. 73-87, 1999. Disponível em:

<https://www.sciencedirect.com/science/article/pii/S0921800998000512> Acesso em: 25 de set. 2018

NATURAL CAPITAL COALITION. This is natural capital. 2017. Disponível em:

<https://naturalcapitalcoalition.org/this-is-natural-capital-2017/> Acesso em: 25 set. 2018.

O’CONNOR, M. Natural capital. Policy Research Brief Series, n. 3, Cambridge Research for the Environment, 1999, 22p.

PAULA, J. de. Desenvolvimento e gestão compartilhada. 2005. Disponível em: $<$ https://docplayer.com.br/70363799-Desenvolvimento-gestao-compartilhada.html $>$ Acesso em: 25 set. 2018.

REIS, J. Estado e mercado: Uma perspectiva institucionalista e relacional. Revista Crítica de Ciências Sociais, v. 95, p. 11-34, dez. 2011. Disponível em: <https://journals.openedition.org/rccs/4355>. Acesso em: 30 set. 2018.

REYES, D. M. V. Valoração econômica dos recursos naturais: uma aplicação do custo de viagem para os recifes de corais do Parque Nacional Natural Corales del Rosario y San Bernardo, Colômbia. 2018. 90 f. Tese (Doutorado) - Curso de Economia, Universidade Estadual de Campinas, Campinas, 2018. Disponível em:

$<$ http://repositorio.unicamp.br/bitstream/REPOSIP/331078/1/Reyes_DumarMiguelVargas_M. pdf $>$ Acesso em: 25 out. 2018.

SCHWARZ, H. Valoração do capital natural: econômica, ecológica ou política? Economia Global e Gestão, Lisboa, v. 17, n. 1, p. 103-116, abr. 2012. Disponível em:

$<$ http://www.scielo.mec.pt/scielo.php?script=sci_arttext\&pid=S0873-

74442012000100007\&lng=pt\&nrm=iso> Acesso em: 25 set. 2018.

SILVA, F. G. D.; MARTINELLI, L. A. S. Economia e Mercado. Curitiba: Instituto Federal do Paraná, 2012. 128 p. Disponível em: <

http://redeetec.mec.gov.br/images/stories/pdf/proeja/economia_mercado.pdf $>$ Acesso em: 26 set. 2018.

STRUMPF, R. O capital natural. 2013. Disponível em: < https://www3.ethos.org.br/cedoc/o-capital-natural/\#.W6vPD2hKjIW >. Acesso em: 25 set. 2018.

WHITACKER, G. M. Território e poder: apropriação, uso e controle de recursos naturais e a irreformabilidade do modo de produção capitalista. Revista Bibliográfica de Geografía Y Ciencias Sociales, Barcelona, XX, 15 out 2015, p.1-30. Disponível em:

<http://www.ub.edu/geocrit/b3w-1135.pdf > Acesso em: 23 set 2018. 


\title{
MOVIMENTO AMBIENTALISTA E DESENVOLVIMENTO SUSTENTÁVEL: ORIGENS, PERSPECTIVAS E INFLUÊNCIAS
}

\author{
Rennisy Rodrigues Cruz ${ }^{10}$ \\ José Roberto Galdino de Barros Filho ${ }^{11}$ \\ Fabiano Duarte Machado ${ }^{12}$
}

\section{INTRODUÇÃO}

Este trabalho tem como objetivo realizar uma discussão sobre o surgimento da teoria do desenvolvimento sustentável e como se deu o início das lutas ambientais a partir das ideologias presentes nos movimentos ambientalistas. Foi desenvolvido a partir do levantamento bibliográfico de literaturas, estudos e pesquisas, além da realização de análises sobre as principais correntes ideológicas do ambientalismo no mundo.

Com a intensificação das discussões sobre as influências antrópicas no meio ambiente e a questão ambiental inserida no cotidiano da sociedade, é dada ênfase ao surgimento de grandes eventos e publicações científicas voltadas à temática ambiental, que suscitaram à intensificação das discussões sobre desenvolvimento da sociedade e meio ambiente.

Na continuidade da discussão, fala-se sobre a ideia acerca do desenvolvimento e meio ambiente, apresentando o surgimento da teoria do ecodesenvolvimento e/ou desenvolvimento sustentável. Para concluir o trabalho, realizou-se uma necessária discussão, dentro da conjuntura global e local, sobre os limites do desenvolvimento sustentável, perfazendo uma crítica fundamentada contra as forças que influenciam o comportamento humano nas relações sociais e com o meio ambiente. Essa discussão tem o objetivo de potencializar proposições e ainda estimular a discussão.

\footnotetext{
${ }^{10}$ Doutoranda em Desenvolvimento e Meio Ambiente - PRODEMA - UFPE, e-mail: rrcambiental@ gmail.com

${ }^{11}$ Gestor Ambiental - IFAL; Esp. em Educação e Meio Ambiente - IFAL; Esp. em Residência Agrária - UFAL, e-mail: roberto_barros@hotmail.com.

${ }^{12}$ Doutor em Linguística - UFAL. Professor do Instituto Federal de Alagoas, e-mail: caetes_cia@yahoo.com.br SUMÁRIO
} 


\section{ECODESENVOLVIMENTO E DESENVOLVIMENTO SUSTENTÁVEL: A GÊNESE DAS DISCUSSÕES}

Diante dos debates e discussões realizados nas décadas de 1960 e 1970, com foco na preocupação mundial sobre as questões ambientais ocasionado, principalmente, pelo modelo hegemônico de desenvolvimento industrial e econômico capitalista, correlacionando esses pontos com a necessidade de melhoria das condições socioeconômicas da sociedade contemporânea, surgiu uma teoria que buscou atender essa problemática:

A preocupação com a preservação do meio ambiente conjugada com a melhoria das condições socioeconômicas da população fez surgir o conceito de ecodesenvolvimento, depois substituído pelo de desenvolvimento sustentável (MONTIBELLER FILHO, 2004, p. 44).

De acordo com Sachs (2009), foi na Conferência das Nações Unidas sobre o Meio Ambiente Humano em Estocolmo, Suécia, no ano de 1972, que surgiu o advento da discussão escala mundial sobre as dependências entre o desenvolvimento e o meio ambiente. Sachs ainda afirmou que, durante a preparação para Estocolmo, duas posições diametralmente opostas foram assumidas: de um lado os que previam a abundância e, no lado oposto, os catastrofistas. Começaram a aparecer diferentes vertentes de pensamento e se intensificou a disputa ideológica sobre visões de desenvolvimento da sociedade.

Nessa disputa ideológica, os que previam abundância, possuíam uma linha de otimismo epistemológico ${ }^{13}$ que, como afirma Sachs (2009), consideravam que as preocupações com o meio ambiente eram descabidas, pois seriam obstáculos para os países em processo de desenvolvimento e industrialização. Para esses, as acelerações do crescimento deveriam ter prioridade e as mazelas produzidas durante esse crescimento poderiam ser neutralizadas quando os países em desenvolvimento atingissem o nível dos países já desenvolvidos, confiando nas inovações tecnológicas e no próprio mercado para solucionar os problemas ambientais.

Em oposição a esse pensamento e com discurso pessimista, estavam os catastrofistas que pediam a estagnação do crescimento demográfico e econômico ou até mesmo do consumo, alertando para um estado caótico que se aproximava. Alguns desses pessimistas eram considerados malthusianos - limitavam o fator principal de perturbação do

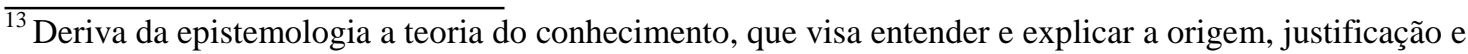
fundamentação do conhecimento.
} 
meio ambiente às consequências da explosão demográfica - pouco levando em consideração outros fatores fundamentais de relações sociais e produtivas da sociedade capitalista.

Já na realização da Conferência de Estocolmo houve um descarte de ambas as posições, logo, após muita discussão, emergiu uma teoria de meio termo em que o crescimento econômico, de certa forma, ainda se fazia necessário. "Mas ele deveria ser socialmente receptivo e implementado por métodos favoráveis ao meio ambiente, em vez de favorecer a incorporação predatória do capital da natureza ao PIB” (SACHS, 2009, p. 52).

Esse paradigma do caminho do meio seria o ecodesenvolvimento, que surgiu como ideia-força para um novo modelo de desenvolvimento, em que: "A construção do novo conceito parte da crítica à visão economicista e ao desenvolvimentismo, denunciando-os como reducionismo econômico e como responsável pela geração dos problemas sociais e ambientais (MONTIBELLER FILHO, 2004, p. 47). Esse novo modelo, tornou-se um conceito com o objetivo de apresentar uma resposta para a crise que se estabeleceu sobre desenvolvimento capitalista e o meio ambiente, ameaçado pelo uso predatório e exaustivo dos recursos naturais.

O ecodesenvolvimento surge para dar uma resposta à necessidade de harmonizar os processos ambientais com os socioeconômicos, maximizando a produção dos ecossistemas para favorecer as necessidades humanas presentes e futuras. (JACOBI, 1999, p. 176).

O conceito de ecodesenvolvimento, de acordo com Jacobi (1999), foi utilizado pela primeira vez pelo canadense Maurice Strong, em junho de 1973, sendo Ignacy Sachs quem largamente formulou e difundiu os princípios básicos dessa nova visão política de desenvolvimento. O novo paradigma “(...) significa o desenvolvimento de um país ou região, baseado em suas próprias potencialidades, portanto endógeno, sem criar dependência externa" (MONTIBELLER FILHO, 2004, p. 47), tendo como objetivo buscar o crescimento das dimensões econômicas não dissociadas dos problemas sociais e ambientais.

Ainda segundo Jacobi (1999) tem como pressuposto a existência de cinco dimensões para a sustentabilidade do ecodesenvolvimento, são eles: 1) sustentabilidade social; 2) sustentabilidade econômica; 3) sustentabilidade ecológica; 4) sustentabilidade espacial e 5) sustentabilidade cultural. Apresentando, assim, uma complexidade importante na leitura desse conceito. Para o qual se acrescenta:

\footnotetext{
Entre as condições para tornar o conceito operacional, destaca-se a necessidade do amplo conhecimento das culturas e dos ecossistemas, sobretudo em como as pessoas se relacionam com o ambiente e como elas enfrentam seus dilemas cotidianos; bem como o envolvimento dos cidadãos no planejamento das estratégias, pois eles são os maiores conhecedores da realidade local (LAYRARGUES, 1997, p. 3).
} 
Considera-se a argumentação exposta coerente, necessária para uma profunda discussão para além da propaganda, pois a realidade concreta demonstra ser bem mais complexa do que a teoria e o estudo dessas dimensões imaginaram inicialmente, e requer uma análise cuidadosa e de longo prazo, para uma aplicação eficiente e que sustente alguns princípios do conceito.

Devido à convergência de conteúdo entre os conceitos de ecodesenvolvimento e desenvolvimento sustentável, o próprio Ignacy Sachs, grande divulgador da teoria do ecodesenvolvimento, passou a utilizar a nova expressão de desenvolvimento sustentável como sinônimo: "Quer seja denominado ecodesenvolvimento ou desenvolvimento sustentável, a abordagem fundamentada na harmonização de objetivos sociais, ambientais e econômicos não se alterou...” (SACHS, 2009, p. 54). Nesse sentido, observamos a aproximação dos princípios, mas um aprofundamento da discussão pode gerar muitas contestações ${ }^{14}$.

De acordo com Montibeller Filho (2004) é a partir de 1980 que se difunde o termo desenvolvimento sustentável, apresentando os principais componentes do então conceito ecodesenvolvimento, se colocando, então, como um novo paradigma para a sociedade.

No ano de 1987 é publicado o Relatório de Brundtland - intitulado Nosso Futuro Comum - que, segundo Montibeller Filho (2004, p. 50), concebeu o desenvolvimento sustentável como: "o desenvolvimento que satisfaz as necessidades presentes, sem comprometer a capacidade das gerações futuras de suprir suas próprias necessidades”. Este conceito agora fortalecido, ganha espaço e tem sido bastante difundido na sociedade.

A seguir vê-se no Quadro 1 uma síntese das principais dimensões do desenvolvimento sustentável.

Quadro 1 - As cinco dimensões do desenvolvimento sustentável

\begin{tabular}{|c|l|c|}
\hline DIMENSÃO & \multicolumn{1}{|c|}{ COMPONENTES } & \multicolumn{1}{c|}{ OBJETIVOS } \\
\hline $\begin{array}{c}\text { SUSTENTABILIDADE } \\
\text { SOCIAL }\end{array}$ & $\begin{array}{l}\text { - Criação de postos de trabalho que permitam a } \\
\text { obtenção de renda individual adequada (à melhor } \\
\text { condição de vida; à maior qualificação } \\
\text { profissional) } \\
\text {-Produção de bens dirigida prioritariamente às } \\
\text { necessidades básicas sociais. }\end{array}$ & $\begin{array}{c}\text { Redução das } \\
\text { desigualdades sociais }\end{array}$ \\
\hline $\begin{array}{c}\text { SUSTENTABILIDADE } \\
\text { ECONÔMICA }\end{array}$ & $\begin{array}{l}\text {-Fluxo permanente de investimentos públicos e } \\
\text { privados (estes últimos com especial destaque para } \\
\text { cooperativismo). } \\
\text { - Manejo eficiente dos recursos. } \\
\text {-Absorção, pela empresa, dos custos ambientais. }\end{array}$ & $\begin{array}{c}\text { Aumento da produção e } \\
\text { da riqueza social sem } \\
\text { dependência externa }\end{array}$ \\
\hline
\end{tabular}

${ }^{14}$ Cf. Philippe Pomier Layrargues: “Do ecodesenvolvimento ao desenvolvimento sustentável: evolução de um conceito?". 


\begin{tabular}{|c|c|c|}
\hline & -Endogeneização: contar com suas próprias forças. & \\
\hline $\begin{array}{l}\text { SUSTENTABILIDADE } \\
\text { ECOLÓGICA }\end{array}$ & $\begin{array}{l}\text {-Produzir respeitando os ciclos ecológicos dos } \\
\text { ecossistemas. } \\
\text {-Prudência no uso de recursos naturais não- } \\
\text { renováveis. } \\
\text {-Prioridade à produção de biomassa e à } \\
\text { industrialização de insumos naturais renováveis. } \\
\text {-Redução da intensidade energética e aumento da } \\
\text { conservação de energia. } \\
\text {-Tecnologias e processos produtivos de baixo } \\
\text { índice de resíduos. } \\
\text { - Cuidados ambientais. }\end{array}$ & $\begin{array}{l}\text { Melhoria da qualidade } \\
\text { do meio ambiente e } \\
\text { preservação das fontes } \\
\text { de recursos energéticos } \\
\text { e naturais para as } \\
\text { próximas gerações }\end{array}$ \\
\hline $\begin{array}{r}\text { SUSTENTABILIDADE } \\
\text { ESPACIAL/GEOGRÁFICA }\end{array}$ & $\begin{array}{l}\text {-Desconcentração espacial (de atividades; de } \\
\text { população). } \\
\text {-Desconcentração/democratização do poder local e } \\
\text { regional. } \\
\text {-Relação cidade/campo equilibrada (benefícios } \\
\text { centrípetos). }\end{array}$ & $\begin{array}{l}\text { Evitar excesso de } \\
\text { aglomerações }\end{array}$ \\
\hline $\begin{array}{l}\text { SUSTENTABILIDADE } \\
\text { CULTURAL }\end{array}$ & $\begin{array}{l}\text {-Soluções adaptadas a cada ecossistema. } \\
\text {-Respeito à formação cultural comunitária. }\end{array}$ & $\begin{array}{c}\text { Evitar conflitos } \\
\text { culturais com potencial } \\
\text { regressivo }\end{array}$ \\
\hline
\end{tabular}

Fonte: Ignacy Sachs (2009); Elaboração: Montibeller Filho (2004, p. 51), adaptado pelos autores.

Apresentando e estudando essas dimensões do desenvolvimento sustentável Montibeller Filho apresenta que "O novo paradigma pressupõe, portanto, um conjunto de sustentabilidades; estas podem ser sintetizadas no seguinte trinômio: eficiência econômica, eficácia social e ambiental" (MONTIBELLER FILHO, 2004, p. 54). Para o autor apenas o cumprimento simultâneo desses requisitos pode atingir o desenvolvimento sustentável

O cumprimento simultâneo do trinômio citado é, então, incompatível com as relações do sistema vigente, já que a estrutura atual é constituída em sua base por uma forma social de produção com priorização de interesses individuais, que acumula valores e riquezas sociais apenas para os proprietários dos meios de produção. Portanto, exclui a maior parte da sociedade desse ciclo. Perpetuando, nesse modelo, uma sociedade com desigualdades econômicas e sociais. Assim, enquanto houver disparidades nesses aspectos, refletirá nas questões ambientais, que serão relegadas como questões secundárias.

Portanto, o funcionamento do capitalismo não dialoga com uma boa desenvoltura econômica associada à qualidade dos aspectos sociais e o equilíbrio ecológico harmonizado que a teoria do desenvolvimento sustentável propõe. Sem o alcance desses pontos o conceito torna-se impossível de materializar-se.

Conclui-se, então, pela impossibilidade de que no mundo capitalista venha a atingir-se o desenvolvimento sustentável, com suas dimensões básicas de equidades intrageracional (garantia de qualidade de vida a todos os contemporâneos), intergeracional (igual garantia às pessoas das próximas gerações, mediante preservação do meio ambiente) e equidade internacional (de todos os países, ou a todo individuo independente de sua localização geográfica). [...] a saber, que as proposições ambientalistas conservadoras do sistema de mercado - que defendem ou toleram - constituem-se em contribuições relevantes 
para amenizar os efeitos da problemática socioambiental; mas que, todavia, não conseguem superar a contradição fundamental do sistema de tender a apropriar-se de forma degenerativa dos recursos naturais (esgotamento) e do meio ambiente (degradação), impossibilitando que sejam concretizadas as equidades sociais e ecológicas intra, intergeracional e internacional do desenvolvimento sustentável. O desenvolvimento sustentável revela-se um mito (MONTIBELLIER FILHO, 2004, p. 291-292).

Com essa reflexão percebemos que a equidade prevista na teoria tornou o conceito de desenvolvimento sustentável uma impossibilidade concreta na sociedade capitalista. Mesmo com equívocos teóricos e filosóficos na interpretação do funcionamento do capitalismo, por ter acumulado expectativas e o discurso da teoria do meio, que garantiria o desenvolvimento da sociedade associado à conservação ambiental, este foi absorvido como discurso da classe dominante. Tal discurso pode ser compreendido como possibilidade da não estagnação do progresso: “O problema é acreditar que a proposta do desenvolvimento sustentável pretende preservar o meio ambiente, quando na verdade preocupa-se tão somente em preservar a ideologia hegemônica" (LAYRARGUES, 1997, p. 7). Destarte, a proposição da ideologia dominante se oculta nas premissas da teoria, mistificando os reais interesses.

Para Alves, (2009, p. 41) "o desenvolvimento sustentável se configura, na verdade, como uma nova roupagem - pseudo-socioambientalista - do sistema capitalista de produção pressionando contra seus padrões que lhe são próprios" a exemplo da produção e consumo desmesurados, da desarmônica relação homem/natureza e da exploração do homem pelo homem. Nessa perspectiva, o capitalismo se travestiu com a teoria do desenvolvimento sustentável para impor um novo paradigma de forma a garantir seus interesses.

\section{AS INFLUÊNCIAS TEÓRICAS E A FORMAÇÃO DO MOVIMENTO AMBIENTALISTA INTERNACIONAL}

A preocupação com as questões ambientais tornou-se mais consistente no período pós-Segunda Guerra Mundial, especificamente após a década de 1960. Neste período há um crescimento da consciência ecológica na reflexão da sociedade, em que alguns atores sociais começaram a se organizar em movimentos voltados diretamente às questões ambientais, tendo em vista que,

[...] a intensificação, na segunda metade do século XX, dos problemas relacionados à exploração desenfreada dos recursos da natureza e a degradação ambiental com caráter global aprofundaram a consciência ecológica em muitos segmentos da sociedade, dando origem ao movimento ambientalista [...] (MONTIBELLER FILHO, 2004, p. 37). 
Percebe-se, então, que o movimento ambientalista emerge e constitui sua pauta central nas questões ecológicas, mas isso não significa que a preocupação desses ativistas é apenas quanto às questões relacionadas ao ambiente natural, como a degradação do solo, desflorestamento, poluição dos lagos e mares e poluição do ar. No decorrer do desenvolvimento do ambientalismo podemos perceber a existência de atuações coadunadas com os vieses social e político, até mesmo pela sua composição heterogênea, através da participação de vários segmentos da sociedade, como se pode ver na afirmação, "Os movimentos ecológicos e pacifistas constituem-se num ponto de inflexão na história da mobilização social e da ação coletiva" (...) (VIOLA, 1987, p. 2). De acordo com este autor os movimentos portadores de valores e interesses universais, como o ambientalista, ultrapassam as fronteiras de classe, sexo, raça e idade.

$\mathrm{Na}$ perspectiva de Viola, percebe-se a demonstração de uma diversidade nas características dos atores ambientalistas, uma magnitude de linhas de atuação e de espaços que o movimento incorpora dentro da sociedade.

Todavia, entende-se que o ambientalismo não supera os antagonismos existentes na atual sociedade de classes. Como se vê:

Os indivíduos que constituem a classe dominante possuem, entre outras coisas, também a consciência e, por isso, pensam; na medida em que dominam como classe e determinam todo âmbito de uma época histórica, é evidente que o façam em toda sua extensão e, consequentemente, entre outras coisas, dominem também como pensadores, como produtores de ideias; que regulem a produção e a distribuição das ideias de seu tempo e que suas ideias sejam, por isso mesmo, as ideias dominantes da época. Por exemplo, numa época e num país em que, portanto, a dominação está dividida, mostra-se como ideia dominante e doutrina da divisão dos poderes, enunciada então como lei eterna (MARX E ENGELS, 1982, p. 72).

Entende-se que os interesses da classe dominante vão se sobrepor à classe oprimida, pois a ideologia dominante é a visão de mundo baseada numa racionalidade técnica instrumental capitalista, que pouco considera a causa ecológica, não obstante quando interessar à obtenção de lucros.

É fundamental a existência de uma politização dos militantes ambientalistas para garantir uma prática eficiente no combate aos problemas de degradação socioambiental alertando, de maneira crítica e profunda, as origens da crise ambiental e do colapso social, sabendo que, apenas a reflexão não materializará uma transformação radical necessária, sendo imprescindível a luta em conjunto com outras frentes em que a questão da classe seja central. 
O movimento ambientalista despertou na sociedade, trazendo consigo uma visão norteada pela priorização da qualidade de vida para o homem harmonizado com o equilíbrio ecológico, apesar de ainda não romperem com a lógica capitalista, em sua maioria. Essas novas perspectivas, ainda que de caráter reformista político e cultural, fizeram emergir, no cenário internacional, novos partidos políticos: os Partidos Verdes (PV) ou também conhecidos como Ecopacifistas.

Esses partidos se formaram como organizações políticas de valores que não pretendiam se transformar em partidos majoritários, não existindo o interesse de governar ou alcançar o poder político da sociedade, visando apenas a agir como transformadores da cultura política, introduzindo, na sociedade, valores pós-consumistas ${ }^{15}$, como é fundamentado na seguinte assertiva:

É claramente o caso do primeiro partido verde, o Partido dos Valores da Nova Zelândia, fundado em 1969, que conseguiu num curto período de tempo afetar profundamente a cultura política, ecologizando os dois partidos tradicionais (Trabalhista e Nacional) que se alternavam historicamente no poder. É a situação presente no Partido Verde Alemão que está influenciando profundamente a socialdemocracia, produzindo a emergência no seu seio da importante corrente ecossocialista. É o caso do partido verde belga que, após cinco anos de trabalho rigoroso e sistemático no Parlamento, conseguiu ser respeitado pela maioria da população e muito considerado pelas agências estatais (VIOLA, 1987, p. 3).

Os Partidos Verdes nasceram com características singulares e ganharam prestigio diante da disseminação do pensamento ecológico na reestruturação política e cultural da sociedade, mas ao decorrer dos anos esses princípios e valores foram deturpados e muitos dos Partidos Verdes começaram a partilhar de outros interesses, descaracterizando a suposta "pureza” da essência inicial dos PV`s, surgindo novas linhas de atuação dos militantes.

O que influenciou no enfraquecimento direto dos Partidos Verdes, foi o fato dos ecologistas políticos não analisarem criticamente a relação do produtivismo e da lógica do lucro da sociedade capitalista, que são incompatíveis com uma perspectiva ecológica real, fazendo com que esses militantes se adaptassem aos vícios do sistema capitalista.

[...] A ausência de uma postura anticapitalista coerente levou a maior parte dos partidos verdes europeus - na França, Alemanha, Itália, Bélgica - a tornar-se simples partidários "eco reformistas" da gestão social-liberal do capitalismo pelos governos de centro-esquerda (LOWY, 2005, p. 46).

Como se nota no contexto internacional, a ausência da proposta de superação da ordem social capitalista nos programas dos PV's, os conduziu, ao longo dessas últimas décadas, para a condição de apêndice dos grandes partidos tradicionais. No caso do Partido

\footnotetext{
${ }^{15}$ Que consomem o necessário para atender apenas as necessidades autênticas do ser humano, garantindo a produção e reprodução da vida social e ecológica.
} 
Verde brasileiro, a construção de seu programa seguiu interesses profundamente eleitoreiros e afins, hoje participando das eleições para executivo e legislativo do país e ocupando alguns cargos políticos de relevante importância na manutenção da lógica capitalista predatória, relegando, inclusive, o seu papel de reformista política e cultural por uma sociedade ecologicamente equilibrada.

$\mathrm{Na}$ composição intelectual e prática do movimento ambientalista encontramos diversas linhas ideológicas que predominam na sociedade. Pode-se observar, de acordo com Viola (1987), que o movimento ambientalista pode ser dividido em quatro principais vertentes ideológicas, composta pelos ecofundamentalistas, ecorealistas, ecocapitalistas e ecossocialistas. Essas posições teóricas e políticas da ecologia serão diferenciadas em seguida.

Os ecofundamentalistas manifestam grande preocupação com os princípios e a pureza do movimento e não acreditam na perspectiva de uma mudança radical da sociedade capitalista judaico-cristã. Segundo Viola, os fundamentalistas são:

[...] de herança anarconiilista, é de horizonte bastante pessimista; acredita na construção de uma sociedade ecologista alternativa na periferia da sociedade materialista, desconsiderando as possibilidades de transformação global da sociedade. Acredita-se irreversível a lógica predatório-extremista do mundo contemporâneo, constituindo-se numa ruptura fundamental com a tradição ocidental judeu-cristã desde que o futuro é inviável (não há terra nem paraíso), restando apenas esperar o fim vivendo de modo coerente com os princípios [...] (VIOLA, 1987, p. 5).

Como podemos observar, os ecofundamentalistas seguem uma linha bastante pessimista, desconsiderando qualquer possibilidade de transformação da realidade social de ordem mundial. Fortemente sectários, bloqueiam a aproximação com outras forças sóciopolíticas, configurando-se com uma postura biologista e anti-humanista.

Já os ecorealistas, diferentemente dos fundamentalistas, acreditam na possibilidade de transformação da sociedade, apresentando um posicionamento que tende a tentar negar tanto o sistema capitalista como o socialista, objetivando a integridade do movimento, no tocante aos seus princípios e sendo flexível na interação com a sociedade. Existe um referencial a ser alcançado pelos ecorealistas, como veremos:

O referencial normativo é um sistema sócio-econômico radicalmente diferente do capitalismo e do socialismo, baseado na pequena propriedade privada e na propriedade cooperativa (predominante média, mas também grande) com autogestão do sistema produtivo e ênfase no Estado de nível local (município, região) como alocador de recursos. Mas o caminho para chegar até aquele passa por uma longa transição, ecologizando progressivamente os capitalismos e socialismos realmente existentes (VIOLA, 1987, p. 5). 
Neste sentido, o referencial normativo que os ecorealistas defendem, apresenta algumas práticas capitalistas como uma sociedade baseada na propriedade privada e com ênfase no Estado de nível local como alocador de recursos. Entende-se que não há um rompimento com o capitalismo e sim uma tentativa de reformar a sua estrutura resgatando influências teóricas rousseaurianas e com tendências ao socialismo utópico ${ }^{16}$, pois mantém as premissas históricas baseadas na riqueza como uso particular e com a existência do Estado, o que significa que continuará havendo uma classe dominante e exploradora.

Os ecocapitalistas acreditam que a única forma de regular eficientemente a relação homem-natureza é através da economia de mercado. Nessa perspectiva, essa corrente ocupa posições estratégicas junto aos órgãos governamentais e setores privados de meio ambiente. Por isso:

[...] argumenta a favor do mercado como alocador de recursos, sendo este disciplinado por um Estado que opera como guardião ecológico da sociedade, sendo compatível com o predomínio da grande propriedade oligopólica [...] O Estado de Bem-Estar Social deverá transforma-se no Estado de Bem-Estar SócioEcológico (VIOLA, 1987, p. 5).

Observamos que a corrente ecocapitalista representa os interesses da classe dominante, aponta a economia de mercado e Estado como mediadores na relação conflituosa entre produção e consumo capitalista e meio ambiente, permanecendo a mesma ordem social vigente. Os interesses dos proprietários e dos governantes estarão sempre em prioridade e o bem-estar social da coletividade secundarizado.

A posição ecossocialista, definitivamente, é favorável a um rompimento com a sociedade capitalista. "Esta postura considera inviável uma ecologização progressiva do capitalismo e do socialismo real tal como é preconizada pelos ecologistas realistas" (VIOLA, 1987). Considera-se, também, todas as alternativas apresentadas pelas outras correntes ideológicas insustentáveis, pois não apresentam alternativas viáveis para uma sociedade socialmente justa e ecologicamente equilibrada. Numa definição simples, Lowy (2005) explana que o ecossocialismo,

\footnotetext{
Trata-se de uma corrente de pensamento e de ação ecológica que faz suas aquisições fundamentais do marxismo - ao mesmo tempo em que livra das suas escórias produtivistas. Para os ecossocialistas a lógica do mercado e do lucro assim como a do autoritarismo burocrático de ferro e do "socialismo real" - são
}

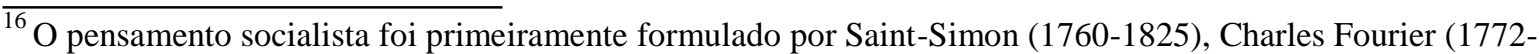
1837), Louis Blanc (1811-1882) e Robert Owen (1771-1858). O socialismo defendido por estes autores foi, mais tarde, denominado de socialismo utópico por seus opositores marxistas (os quais, por oposição, se autodenominavam socialistas "científicos"), e vem do fato de seus teóricos exporem os princípios de uma sociedade ideal sem indicar os meios para alcançá-la. O nome vem da obra Utopia de Thomas More (14781535).
} 
incompatíveis com as exigências de preservação do meio ambiente natural (LOWY, 2005, p. 47).

É nessa perspectiva que se constitui o pensamento ecossocialista que, ancorando-se no marxismo, desenvolve práticas e ações ecológicas, lutando para a transformação radical do sistema vigente e construindo uma nova sociedade socialista e ecológica.

Viola, coloca que as vertentes ideológicas do movimento ambientalista, baseiam-se nas quatro correntes apresentadas, e ainda mostra sinteticamente de que forma estão distribuídas:

\begin{abstract}
No movimento social ecologista mundial a posição ecologista realista é definitivamente predominante, sendo minoritárias as outras três. Fora do movimento ecológico a situação muda. Nos setores sensíveis a ecologia da opinião pública ocidental a posição ecocapitalista é predominante, sendo secundária a posição ecologista-realista. A posição ecossocialista predomina nos setores sensíveis à ecologia da subcultura socialista-comunista ocidental (por exemplo, a forte corrente verde do partido comunista Italiano encabeçada por P. Ingrao) e nos setores sensíveis à ecologia da oposição democrática em algumas sociedades da Europa Oriental (Polônia, Alemanha, Hungria, Tchecoslováquia). Finalmente a posição ecologista fundamentalista, por definição, não existe fora do movimento ecologista (VIOLA, 1987, p. 06).
\end{abstract}

Apesar de utilizarmos essa proposta metodológica apresentada por Viola, acreditamos que é possível e mais coerente realizar uma divisão ainda mais simplificada, em que o movimento ecológico pode ser dividido em apenas duas correntes: ecocapitalistas e ecossocialistas. Pois, as correntes ecofundamentalista, ecorealistas e ecocapitalistas estabelecem posturas semelhantes, pois, não fazem uma crítica profunda ao sistema capitalista, querem estabelecer práticas dentro da atual estrutura social, portanto, apenas encontrarão soluções mitigadoras e pontuais para os problemas socioambientais, não contribuindo para a erradicação dos mesmos, mas, garantindo-lhes manutenção. A corrente ecossocialista rompe radicalmente com a sociedade capitalista-predatória e objetiva a construção de uma nova sociedade, baseada na justiça social e na conservação do meio ambiente.

\title{
4 A QUESTÃo AMBIENTAL E A FORMAÇÃO DO MOVIMENTO AMBIENTALISTA BRASILEIRO
}

O contexto ambiental brasileiro não é diferente dos outros países, principalmente quando se observa os países em desenvolvimento e subdesenvolvidos. Demonstra uma problemática bastante complexa, com a exploração ambiental desenfreada e má gestão dos recursos naturais, como por exemplo, o desflorestamento a partir da colonização do país, a poluição do ar gerada, em sua maior parte, pelas indústrias e pela queima de combustíveis 
fósseis dos meios de transporte urbanos e, ainda, da falta de saneamento básico e de aterros sanitários importantes para um descarte e tratamento adequado dos resíduos domésticos, industriais e de outras origens. No Brasil, outro ponto que se destaca são os problemas sociais desencadeados pelo modelo de desenvolvimento capitalista adotado:

\begin{abstract}
As particularidades do processo de formação do capitalismo brasileiro fizeram com que o processo de separação dos trabalhadores dos meios de produção seguisse um caminho diferente das economias clássicas, ou seja, esse processo ocorre no Brasil de maneira simultânea e dependente das transformações que estão ocorrendo nos grandes centros do capitalismo mundial (MACHADO, 2010, p. 54).
\end{abstract}

Sendo assim, entende-se que, historicamente, o capitalismo brasileiro tem sua base econômica e ideológica influenciada ou subordinada pelos centros avançados do capitalismo mundial, constituindo-se um país de sociedade conservadora. Em todas as faces do capitalismo encontramos a apropriação dos meios de produção, da força de trabalho e concentração de riquezas para os seus proprietários, portanto, uma relação desigual e injusta. Seja qual for a metodologia, a sede pela obtenção de lucros explora demasiadamente o meio ambiente ${ }^{17}$.

$\mathrm{Na}$ luta contra essa dinâmica degradante do sistema de produção que tem como eixo central o capital, referente à degradação ambiental, surge o movimento ambientalista, onde "o Brasil é o país da América Latina em que os movimentos ecológicos nascem mais cedo e adquirem uma relevância maior até o momento" (VIOLA, 1987, p. 6), tendo um importante papel na disseminação da consciência ecológica e nas lutas ambientalistas.

Sendo assim, no Brasil, o movimento ambientalista nasce na década de 1950, tendo como principal atuação, em princípio, as denúncias. $\mathrm{O}$ movimento se colocava contra o modelo de políticas governamentais industriais, uma característica que já existia em alguns países mais desenvolvidos. Neste período, as primeiras iniciativas foram realizadas por grupos preservacionistas e conservacionistas, caracterizando o começo das discussões acerca das questões ambientais,

No Brasil, as primeiras iniciativas ambientalistas se originam nas ações de grupos preservacionistas na década de 50. Em 1955 é fundada a união Protetora do Ambiente Natural (UPAN) pelo naturalista Henrique Roessler em São Leopoldo no Rio Grande do Sul, e em 1958 é criada no Rio de Janeiro a Fundação Brasileira para a conservação da Natureza (FBCN) com objetivos e modo de atuação estritamente conservacionista, que centrava suas atividades na preservação da fauna e da flora, com particular ênfase naquelas ameaçadas de extinção. (JACOBI, 2003, p. 2).

Neste sentido, percebe-se que o Brasil ainda estava emergindo na discussão da causa ambiental. As lutas eram direcionadas às atividades conservacionistas, longe, ainda,

\footnotetext{
${ }^{17}$ Quando falamos em meio ambiente inserimos todos os seres existentes na terra (bióticos e abióticos). 
das questões inter-relacionadas à sociedade (problemas sociais). $\mathrm{O}$ movimento vem se solidificar com a combinação de alguns fatores internos e externos no final da década de 1960 e início da década de 1970.

De acordo com Jacobi (2003) os fatores externos estão ligados à Conferência de Estocolmo, em 1972, e à volta dos ativistas políticos anistiados em 1979, que sofreram bastante influência dos movimentos ambientalistas dos EUA e Europa, como, por exemplo, Fernando Gabeira, que iniciou a organização do Partido Verde no Brasil. E, alguns fatores internos são, o aumento da destruição da floresta amazônica e o desenvolvimento desmesurado acelerado.

Afirma-se que "o Brasil acordou subitamente para a preocupação com os recursos naturais não-renováveis com o choque do petróleo em 1973. Esta preocupação era a única ponte existente entre o movimento ecológico e setores da tecnoburocracia estatal" (VIOLA, 1987, p. 8). Isso é resultado da preocupação com a escassez de petróleo, que comprometeria a confecção de diversos produtos, deixariam de ser produzidos afetando diretamente a economia do país.

Outro fator interessante foi o surgimento da Associação Gaúcha de Proteção Ambiental Natural - AGAPAN, fundada em Porto Alegre pelo ativista José Lutzemberger, em 1971, que baseava sua militância na preservação da natureza como uma maneira de salvar/preservar a vida da humanidade. Uma das conquistas da AGAPAN foi a aprovação da primeira lei estadual de Agrotóxicos, em 1983. A associação vinha lutando, desde sua fundação, contra o uso abusivo de agrotóxicos. Assinalando que,

[...] o uso abusivo de agrotóxicos, uma luta que a Associação Protetora do Meio Ambiente (AGAPAN), no Rio Grande do Sul, tinha, desde a sua fundação, como uma das suas prioridades. A sua atuação foi muito intensa e não só concretizou uma pressão bem sucedida junto à assembleia legislativa daquele estado que culminou na aprovação da primeira lei estadual de agrotóxicos em 1983 como o seu exemplo se disseminou por Santa Catarina, Paraná e São Paulo, onde leis similares foram aprovadas em 1984 [...] (JACOBI, 2003, p. 6).

O movimento ambientalista no fim da década de 1970 já tinha realizado algumas campanhas nos âmbitos local e nacional e o número de organizações ambientais cresceram assustadoramente no decorrer da sua evolução:

A partir de fins da década de 1970 consegue realizar algumas campanhas de âmbito regional ou mesmo nacional, e o número de grupos de base cresce de forma extraordinária, de aproximadamente quarenta em 1980 para quatrocentos em 1985. Até esse ano o ambientalismo brasileiro tem um caráter bissetorial (grupos de base e agências estatais ambientais), e sua luta orienta-se para o controle da poluição urbano-rural e a preservação de ecossistemas naturais. (VIOLA; LEIS, 1995, p.1). 
Partindo desse pressuposto, percebe-se que o ambientalismo continuava restrito aos grupos de base e ao governo e ainda estava com suas reivindicações pautadas no preservacionismo que, "no fundo, a dualidade observada na relação das agências com as entidades representa a dialética ${ }^{18}$ existente no país entre Estado e sociedade" (JACOBI. 2003, p. 4). Isso significa que o estado não representava os interesses coletivos da sociedade, por isso a sociedade se organizava em grupos de base para reivindicar maior atuação do Estado para os problemas relacionados à causa ambiental.

No ano de 1973 são criadas algumas agências ambientais como a Secretaria Especial de Meio Ambiente (SEMA), que de acordo com Viola (1987), foi criada pelo então presidente Geisel, com um único objetivo, que seria cumprir exigências de organismos internacionais que cobravam a existência formal de algum órgão com este caráter para a realização de relatórios de impactos ambientais, para poder abrir diálogos sobre empréstimos ou financiamento de grandes obras públicas. A SEMA era vinculada ao Ministério do Interior e, simultaneamente, surgem outras organizações, com podemos verificar:

[...] Também nesta época alguns estados brasileiros mais industrializados vão criar as primeiras agências ambientais para controle da Poluição, como a companhia de tecnologia e saneamento ambiental (CETESB), em São Paulo, e a Fundação de Energias do Meio Ambiente, no Rio de Janeiro (JACOBI, 2003, p. 3).

Estas iniciativas seriam uma maneira que o governo brasileiro encontrara para atenuar a imagem negativa que obteve na conferência de Estocolmo, pois o Brasil estava preocupado principalmente com seu crescimento industrial, independente dos problemas ecológicos que o país enfrentaria.

O movimento ambientalista, ainda na década de 1970, se restringia, como dito, às lutas voltadas ao combate da poluição atmosférica, desflorestamento e apoio à preservação de ecossistemas naturais. Nesse período, percebe-se um grande afastamento dos movimentos ambientalistas em relação à temática da justiça social, decorrente do distanciamento das organizações ambientais dos movimentos sociais.

No decorrer dos anos surgem algumas políticas e órgãos voltados às questões ambientais, como, por exemplo, é criado, em 1983, o Conselho Nacional de Meio Ambiente (CONAMA), através do Decreto Federal no 88.351 que, segundo Pinto (2004, p. 21): “o aparecimento do CONAMA significará a inserção definitiva da temática ambiental no plano

\footnotetext{
${ }^{18}$ Arte de argumentar ou discutir. Maneira de filosofar que procura a verdade por meio de oposição e conciliação de contradições (lógicas ou históricas).
} 
das atividades do Poder Público, em nível nacional”. No CONAMA também há a previsão de participação de entidades ambientalistas, que se discute a seguir.

Também nos anos de 1980, destacamos especificamente a introdução da temática ambiental na Constituição Brasileira, em que foi inserida, no plano jurídico e político brasileiro, a importância de preservação do meio ambiente.

Consideramos pertinente no contexto legislativo brasileiro a existência dessa preocupação pela conservação do meio ambiente e qualidade de vida do povo, mesmo que de maneira formal. Existe, na Constituição, o Art. 225, capítulo VI - Do Meio Ambiente, inciso VI - que destaca a necessidade de promover a Educação Ambiental em todos os níveis de ensino e a conscientização pública para a preservação do meio ambiente. Sabe-se que no Brasil existe uma legislação ambiental bastante avançada em relação a outros países, mas, existe uma série de fatores que tornam essas políticas do Estado ainda ineficientes, como a falta de aplicação e de fiscalização dessas premissas previstas na legislação.

Por fim, no ano de 1989, cria-se o Instituto Brasileiro do Meio Ambiente e dos Recursos Naturais Renováveis (IBAMA), pela fusão da SEMA, SUDEPE, SUDHEVEA e IBDF $^{19}$ e em seguida, no ano de 1992, mesmo ano da Rio - 92, cria- se o Ministério do Meio Ambiente.

Com o aumento da preocupação pública com os problemas ambientais, o movimento ambientalista deixa de ter uma atuação bissetorial para uma atuação multissetorial, bastante complexa desde a fundamentação teórica que lhe dá suporte à prática da militância. Segundo Viola e Leis (1995), este ambientalismo está dividido em oito principais setores, como veremos no Quadro 2.

Quadro 2 - Principais setores na divisão do movimento ambientalista brasileiro

\begin{tabular}{|c|l|}
\hline SETOR & \multicolumn{1}{c|}{ DESCRIÇÃO } \\
\hline $\begin{array}{c}\text { Ambientalismo Stricto } \\
\text { Sensu }\end{array}$ & $\begin{array}{l}\text { As associações e grupos comunitários ambientalistas, que agora diferenciam-se em três } \\
\text { tipos (profissionais, semiprofissionais e amadores) atingem um total de } \\
\text { aproximadamente setecentos em 1989; }\end{array}$ \\
\hline $\begin{array}{c}\text { Ambientalismo } \\
\text { governamental }\end{array}$ & As agências estatais de meio ambiente (no nível federal, estadual e municipal); \\
\hline $\begin{array}{c}\text { Socioambientalismo } \\
\text { As organizações não-governamentais, sindicatos e movimentos sociais que têm outros } \\
\text { objetivos precípuos, mas incorporam a proteção ambiental como uma dimensão } \\
\text { relevante de sua atuação; }\end{array}$ \\
\hline $\begin{array}{c}\text { Ambientalismo dos } \\
\text { cientistas }\end{array}$ & $\begin{array}{l}\text { As pessoas, grupos e instituições que realizam pesquisa científica sobre a problemática } \\
\text { ambiental; }\end{array}$ \\
\hline $\begin{array}{c}\text { Ambientalismo } \\
\text { empresarial }\end{array}$ & $\begin{array}{l}\text { Os gerentes e empresários que começam a pautar seus processos produtivos e } \\
\text { investimentos pelo critério da sustentabilidade ambiental; }\end{array}$ \\
\hline
\end{tabular}

\footnotetext{
${ }^{19}$ Siglas: SEMA- Secretaria Especial do Meio Ambiente; IBDF- Instituto Brasileiro de Desenvolvimento Florestal; SUDEPE- Superintendência de Pesca; e SUDHEVEA- Superintendência de Borracha.
} 


\begin{tabular}{|c|l|}
\hline $\begin{array}{c}\text { Ambientalismo dos } \\
\text { políticos profissionais }\end{array}$ & $\begin{array}{l}\text { Os quadros e lideranças dos partidos existentes que incentivam a criação de políticas } \\
\text { específicas e trabalham para incorporar a dimensão ambiental no conjunto das políticas } \\
\text { públicas; }\end{array}$ \\
\hline $\begin{array}{c}\text { Ambientalismo } \\
\text { religioso }\end{array}$ & $\begin{array}{l}\text { As bases e representantes das várias religiões e tradições espirituais que vinculam a } \\
\text { problemática ambiental à consciência do sagrado e do divino; }\end{array}$ \\
\hline $\begin{array}{c}\text { Ambientalismo dos } \\
\text { educadores }\end{array}$ & $\begin{array}{l}\text { (Da pré-escola, primeiro e segundo graus), jornalistas e artistas fortemente preocupados } \\
\text { com a problemática ambiental e com a capacidade de influir diretamente na consciência } \\
\text { das massas. }\end{array}$ \\
\hline
\end{tabular}

Fonte: principal: Viola; Leis, (1995, p. 1). Elaborada pelos autores (2017).

Neste sentido, Viola; Leis (1995) apresentam a ideia de que as preocupações com as questões ambientais se tornaram parte do cotidiano da sociedade, sendo incorporada em diversos espaços públicos e privados da sociedade. No entanto, existe, por trás dessa multisetorialidade que os próprios autores propõem, a omissão da luta de classes e das distintas formas como são discutidas essa temática a partir da matriz ideologia de cada grupo.

O principal evento ambientalista no Brasil foi a Conferência das Nações Unidas sobre o Meio Ambiente e Desenvolvimento (UNCED), conhecida como Rio 92 ou Eco 92. De acordo com Jacobi (2003, p. 16) "a Rio 92 obrigou os atores a se situarem num espaço multissetorial, levando sua reflexão e prática em direção ao desenvolvimento sustentável”, em que, acrescenta o autor:

Muda o conteúdo, diminuindo significativamente o discurso que falava em proteção ambiental de forma isolada que é substituído por um que advoga a necessidade de pensar as relações entre o desenvolvimento econômico e a proteção ambiental, como eixos de convergência de relação entre sociedade e Estado (JACOBI, 2003, p. 16).

O que se observa é que mesmo com uma visão de atuar multissetorialmente e se utilizando de um discurso ambientalista, o pensamento ancorado pelo desenvolvimento capitalista ignora a necessidade real de proteção ambiental. Pensamento que esteve presente na Rio 92, disseminando a ideia de desenvolvimento para mitigar a degradação ambiental e buscar novas políticas de conservação ecológica, mas mantendo, contraditoriamente, as mesmas relações sociais.

O ano de 1992 também é marcado pela criação do Ministério do Meio Ambiente (MMA), uma estrutura do Estado brasileiro que se configura para formular e fortalecer as políticas públicas de meio ambiente no país, tendo como missão promover estratégias e práticas de conhecimentos para a proteção e recuperação do meio ambiente e a valorização dos serviços ambientais, para que houvesse o compartilhamento dessas propostas em todos os níveis e instâncias de governo e sociedade. 
No decorrer dos anos seguintes surgiram diversas políticas ambientais: em 2007 foi criado o Instituto Chico Mendes de Conservação da Biodiversidade (ICMBIO), órgão ambiental do governo brasileiro, uma autarquia ambiental vinculada ao Ministério do Meio Ambiente, criado pela lei 11.516, de 28 de agosto de 2007, que é responsável pela administração das unidades de conservação federais, além de fomentar e executar programas de pesquisa, proteção e conservação da biodiversidade em todo o Brasil, as quais se tornaram uma das principais políticas implementadas no país.

$\mathrm{Na}$ atualidade existem diversas leis ambientais que disciplinam as possibilidades e limites das atividades em determinadas áreas. A Política Nacional de Resíduos Sólidos PNRS, lei Federal n 12.305 de 2010, por exemplo, obriga a extinção dos lixões, recuperação das áreas degradadas e a disposição final dos rejeitos ambientalmente adequada em aterros sanitários.

Em outras escalas também foram criadas legislações sobre uso do solo, uso dos recursos naturais, bem como atos administrativos, planos diretores de desenvolvimento urbano, planos de gerenciamento costeiro, planos de gestão de resíduos sólidos, de saneamento básico, planos de manejo de unidades de conservação e de recursos hídricos. Todas estas intervenções sejam elas subjetivas ou objetivas vão moldando o espaço geográfico. Algumas leis têm o poder de congelar alguns espaços, como o caso do SNUC, criando áreas de proteção integral, mas que por outro lado, pode impedir, mesmo que em poucos casos, o avanço da apropriação e destruição do ecossistema local.

Contrariamente a alguns ínfimos progressos na área ambiental, houve alteração do Código Florestal em 2012, alvo de várias mobilizações em todo território nacional em decorrência de retrocessos ambientais defendidos pela bancada ruralista do Congresso Nacional, fortemente representada em todas as esferas dos cargos políticos no país.

Esse grupo, detentor de grandes latifúndios, tenta garantir por meio da força e poder político, a acumulação de riquezas a partir da exploração dos recursos naturais e da classe trabalhadora, criminalizando os movimentos sociais e institucionalizando crimes bárbaros contra ambientalistas e agricultores ao longo da história, fatos estes cruelmente intensificados no atual governo. Grandes áreas vêm sendo desmatadas, áreas indígenas ameaçadas e seus líderes violentados e mortos, além de uma avançada flexibilização das políticas públicas socioambientais que resguardavam alguma proteção ao ambiente, e ainda perseguições políticas e a liberação demasiada da utilização de agrotóxicos na agricultura. 


\section{CONSIDERAÇÕES FINAIS}

O surgimento da discussão sobre a intervenção negativa do homem na natureza emergiu como forma de crítica ao modelo técnico instrumental capitalista imposto para o desenvolvimento. Notam-se registros concretos da preocupação direta com o meio ambiente no âmbito mundial, no curso recente da história, que serviu para disseminação da discussão ambiental, mas que não problematizaram de forma concreta as suas razões, para que haja a superação dos problemas ambientais.

Entendemos que o avanço da dinâmica capitalista, que centraliza riquezas e explora massivamente o meio ambiente, desmontou qualquer possibilidade séria, que vai além do marketing, de se atingir um estágio de desenvolvimento sustentável. Acreditamos que as premissas de Ignacy Sachs poderão ter utilidade, caso sejam discutidas dentro de um sistema que garanta a equidade em toda estrutura da sociedade, com base no trabalho associado, sem a propriedade privada e que garanta o desenvolvimento pleno das potencialidades humanas. O que pouco se mostra possível nos marcos do capitalismo.

Partindo para a formação do movimento ambientalista internacional, encontramos a sua origem na segunda metade do século XX, em que a exploração dos recursos naturais de maneira desordenada, que causava uma grave degradação do meio ambiente, aprofundou a consciência ecológica em alguns segmentos da sociedade.

Percebemos que o movimento integrou, desde sua gênese, a heterogeneidade, agregando pessoas de diversos setores da sociedade. Contudo, nesse momento histórico, a teoria marxiana e o movimento operário internacional entram num profundo processo de refluxo, que tem sua origem na falência do bloco soviético e na ofensiva neoliberal, fatos que contribuíram para a rejeição da teoria de Marx na compreensão das relações capitalistas e sua relação com as questões ambientais.

Ainda, o movimento ganhou um aspecto político destacado mundialmente com a criação dos primeiros Partidos Verdes que buscavam fomentar uma transformação na cultura política de outros partidos e na sociedade, e que, no decorrer da história, foram conduzidos à condição de apêndices dos partidos tradicionais, fragilizando sua identidade, perdendo importância e influência no plano ecológico político.

No desenvolvimento histórico do ambientalismo, mesmo utilizando a metodologia do autor Viola, por meio da definição das quatro correntes ideológicas do movimento ambientalista, concluímos que o movimento possui, atualmente, uma divisão mais simplificada, entre apenas duas frentes de atuação: a ecocapitalista, que absorve e influencia 
ideologicamente as correntes ecofundamentalistas e eco realistas, pois sem uma profunda crítica, as relações capitalistas contribuem para uma manutenção do sistema vigente; restando como perspectiva de transformação, os ecosocialistas, que preservam uma linha de pensamento crítico ao sistema atual de produção e rompem com qualquer estrutura que favoreça a essa manutenção, podendo contribuir para uma transformação radical da sociedade.

Por fim, constata-se que toda a discussão teórica tem sido imprescindível para compreensão acerca da origem da questão ambiental e suas principais correntes ideológicas. No momento atual vivemos severos retrocessos quanto à questão ambiental, além de perseguições políticas, preponderando a descredibilização científica, favorecendo a ascensão de ações que se aproximam do prisma do fascismo no Brasil.

Destacamos, enfim, que o conteúdo apresentado neste trabalho começou a ser produzido em 2010, período em que não se tinham muitas pistas de que em pleno 2019 estaríamos vivendo os resultados cruéis de um golpe de Estado, ocorrido em 2016, através do qual alguns dos avanços nos direitos sociais e as tímidas conquistas ambientais passariam a ser intensa e perversamente assolados.

\section{REFERÊNCIAS}

AGAPAN. Aos 40 Anos, Agapan mantém campanhas de preservação de biomas. Disponível em: <http://agapan.blogspot.com/2011/04/aos-40-anos-agapan- mantemcampanhas-de_1850.html > Acesso em: 04 junho. 2018.

ALVES, Sherliton da Silva. Os (des)caminhos do movimento ambientalista: da crítica ao padrão insustentável de produção e consumo a produção e consumo "verde". Trabalho de Conclusão de Curso (Graduação em Gestão Ambiental). Instituto Federal de Alagoas, Marechal Deodoro, 2009.

JACOBI, Pedro Roberto: Meio ambiente e sustentabilidade. IN: CEPAM: o município no Século XXI. São Paulo, 1999, p. 175-184.

Movimento ambientalista no Brasil: representação social e complexibilidade da articulação de práticas coletivas. In: Ribeiro, W. (org.) Publicado em Patrimônio Ambiental - EDUSP- 2003.

LAYRARGUES. Philippe Pomier. Do eco desenvolvimento ao desenvolvimento sustentável: evolução de um conceito? Proposta, n. 25, v. 71, 1997. Disponível em: http://material.nereainvestiga.org/publicacoes/user_35/FICH_PT_32.pdf. Acesso em: 15 julho. 2018.

LÖWY, Michael. Ecologia e Socialismo. São Paulo: Cortez, 2005. 
MACHADO, Fabiano Duarte. Os limites do discurso da igualdade racial no Brasil. Dissertação (Mestrado em Educação Brasileira). Universidade Federal de Alagoas, Centro de Educação. Maceió, 2010.

MARX, Karl; ENGELS, F. A ideologia alemã. 3.ed. São Paulo: Ciências Humanas, 1982.

MONTIBELLER FILHO, Gilberto. O mito do desenvolvimento sustentável: meio ambiente e custos sociais no moderno sistema produtor de mercados. 2. ed. Florianópolis: UFSC, 2004.

PINTO, Anivaldo de Miranda. Política ambiental e ambientalismo em Alagoas:

Surgimento, conflitos e interações. Dissertação (Mestrado em Desenvolvimento e Meio ambiente), Universidade Federal de Alagoas, Maceió, 2004.

SACHS, Ignacy: Caminhos do Desenvolvimento Sustentável / organização: Paulo Yone Stroh. Garamond. Rio de Janeiro, 2009.

VIOLA, Eduardo J. O movimento ecológico no Brasil (1974-1986): do ambientalismo à ecopolítica, 1987. Disponível em:

<http://www.anpocs.org.br/portal/publicacoes/rbcs_00_03/rbcs03_01.htm>. Acesso em: 15 junho. 2018.

LEIS, H. R: O ambientalismo multissensorial no Brasil para além da Rio-92: O desafio de uma estratégia globalista viável.1995. Disponível em:

$<$ http://arquesustenta.weebly.com/uploads/2/9/2/3/2923945/o_ambientalismo_multiss etorial_no_brasil.pdf> . Acesso em 23/08/2011>. Acesso em 25 junho. 2018. 


\section{$\infty$ ELO UM}

\section{Bruno Augusto Nogueira Monteiro Pontes}

Estabelecer as relações e correlações entre tantos fenômenos no bojo da unidade dialética da sociedade-natureza numa realidade dinâmica, marcada pela volatilidade, pelo imediatismo e materialismo, como a que vivemos é um dos desafios para melhor compreender o ambiente em sua complexidade. Por isso, as reflexões aqui, assim como nos demais Elos que constituem esta obra, buscam tecer as ligações entre os capítulos a fim de demonstrar aos leitores e leitoras um exercício de integrar discussões e as múltiplas formas de perceber a realidade, num esforço interdisciplinar para melhor compreender a complexidade ambiental. Ainda que de forma preliminar e com as imprecisões próprias de uma prática que deve estar em constante aprimoramento.

A trama forjada pela Natureza ${ }^{20}$, seus fenômenos espontaneamente integrados, suas inter-relações complementares atuando cooperativamente para o equilíbrio denotam ligações essenciais, a sinergia simbiótica que engendra nossa constituição - na evolução histórica enquanto sociedade. Evitar, portanto, pensamentos maniqueístas tácitos, pragmáticos, operacionais que desaconselham imissões intelectuais mais amplas observando com sensibilidade o ambiente que nos conforma pode ser a chave para tantas respostas buscadas. É na simplicidade, apreendendo a parcimônia dos processos naturais, a dinâmica dos homens lentos (SANTOS, 2006) que reside o caminho a ser retomado nos atuais descaminhos transcorridos.

Neste sentido, estabelece-se como pressupostos transversais para as ponderações que as ações humanas, considerando o período histórico recente, pouco têm refletido princípios, valores e uma ética que considere a racionalidade ambiental (LEFF, 2004), os limites de exploração do ambiente, de degradação da nossa casa comum, as quais têm ensejado reflexos como a atual crise civilizatória e o crescimento dos desastres e eventos naturais extremos. Tais reflexos simbolizam, então, uma espontânea tentativa de pôr em equilíbrio o que vem

20 "Assumir uma discussão sobre a Natureza nos dá real dimensão do paradoxo em que foi construída a ideia antropocêntrica. Aqui assumimos a difícil tarefa de mencioná-la com conotações diferentes em alguns momentos, adotando a visão da natureza contemporaneamente, “[...] que tem servido como um dos suportes para o modo como produzimos e vivemos, que tantos problemas nos tem causado [...] (PORTO-GONÇALVES, 2013, p. 24), enquanto recurso, mercadoria - ainda que saibamos a intencionalidade que reside detrás desta concepção e tenhamos uma opinião crítica quanto a isso. E, adotando uma conotação enquanto gênese de todas as coisas, como totalidade, da qual o homem é parte, considerando a complexidade das relações dos seres, que ao nosso ver é a que se põe pertinente e com a qual nos alinhamos. Conceituação esta assumida como um desafio para a sociedade atualmente" (PONTES, 2017). 
sendo desequilibrado, sobretudo, desde a explosão do fenômeno da urbanização em todo o mundo. Estes pressupostos ilustram as inexoráveis conexões do homem com seu meio.

Deste modo, homens e mulheres adensados de maneira crescente nas urbes - por estratégia e conveniência, onde se materializaram os ideais construtivos para o crescimento instituíram sociedades diversas. Gerou-se, destarte, a irrupção de uma artificialidade aparente que se sobrepôs à "selvageria da natureza" não adestrada, sem que entendêssemos, com profundidade, o nível de integração dos processos e fluxos em que estamos conectados, enquanto parte de uma só teia. Estas redes de processos entrelaçados e tecidos conjuntamente por leis universais das quais não temos compreensão integral, mas que atuam naturalmente para unificar tudo o que existe.

Logo, a urbanização e os processos urbanos de maneira geral recrudesceram e aceleraram a disjunção vã entre "artificialidade e naturalidade", sociedade e natureza. Isto tendo em conta que somos hoje mais de 7,5 bilhões de habitantes dentre os quais $54 \%$ vivendo em áreas urbanas, com uma perspectiva de chegar a $66 \%$ da população mundial total nestas áreas até 2050 (ORGANIZAÇÃO DAS NAÇÕES UNIDAS-ONU, 2018). Assim, a materialização de uma produção do espaço hostil à nossa natureza essencial tem como reflexo um distanciamento inverossímil, porque integramos dialética e dialogicamente o mesmo ambiente, a physis como denominavam os filósofos pré-socráticos, constituindo uma socionatureza, como afirma Swyngedouw (2009). A esse respeito, tal autor esclarece que o processo urbano compreende uma rede de processos entrelaçados a um só tempo humanos e naturais, reais e ficcionais, mecânicos e orgânicos. E que, portanto, não há nada genuinamente social ou natural nas cidades, são ao mesmo tempo naturais e sociais, inseparáveis, sociedade e natureza são mutuamente integrados e infinitamente simultâneos (Ibidem, p. 100).

O homem, portanto, é a natureza tomando consciência de si própria, como afirma Porto-Gonçalves (2013). Assim, nossos comentários objetivam contribuir com o rompimento das fronteiras que perpetram uma apreensão distinta de "sociedade" e "natureza" buscando integrá-las, porém compreendendo as diferenciações. Como também desenvolver linguagens que mantenham a unidade dialética da socionatureza, esse híbrido metabolizado por processos naturais e sociais que "incorpora processos químicos, físicos, sociais, econômicos, políticos e culturais de maneiras altamente contraditórias, mas inseparáveis. Todo corpo e coisa são um 'ciborgue', um mediador - parte social e parte natural, mas sem fronteiras delineadas“ (SWYNGEDOUW, 2009, p. 105). 
No âmbito destas discussões a abordagem do primeiro capítulo traz contribuições da visão geográfica, em diálogo com as demais ciências, inter-relacionando-as, para evidenciar que a geografia buscar trazer uma visão de unidade da realidade, esta que tentam turvar com propósitos específicos. A capacidade interdisciplinar própria desta ciência dá-lhe caráter expressivo para contribuir com a ideia de unidade entre sociedade e natureza, de um ambiente dialético, mas dialógico, em constante movimento em algum sentido. Os aspectos físico-naturais e os aspectos humanos imbricam-se de forma que não há como percebê-los, hoje, dissociados. Perceber os elos é imperativo e a geografia é uma das ciências capazes de promover esta compreensão.

A abordagem do segundo capítulo revela os desdobramentos de uma visão deturpada que persevera em se fazer hegemônica, de uma globalização que preconiza a integração de mercados, mercadorias, dinamiza fluxos de dados e informações, mas distancia as pessoas. Traz luz, portanto, à compreensão crítica da crise ambiental relacionada ao processo de globalização imposta por processos de forma vertical e homogeneizantes, sem considerar os ambientes de vivência das pessoas, seus territórios e suas territorialidades.

A ligação entre estes capítulos reside na possibilidade de leitura da realidade por meio da lente geográfica, que apreende os aspectos físicos-naturais relacionados aos aspectos humanos mostrando a interdependência entre eles. Denotam a imensa possibilidade de compreender a socionatureza de forma holística, no sistema mundo, que quer integrar o espaço, o ambiente, romper fronteiras, mas, tenciona as relações sociais que se dão sobre este mesmo espaço. Gerando conflitos de toda ordem porque os propósitos ensejados pela "globalização" foram retórica e meticulosamente deturpados, ou seja, não são verdadeiramente considerados, senão, sobretudo, para atender aos interesses econômicofinanceiros de alguns atores.

A ideia lançada pelo geógrafo Yves Lacoste em seu livro seminal “ A geografia isso serve, em primeiro lugar, para fazer a guerra" (1976), por exemplo, traz as bases para compreensão de que a partir da apropriação do saber geográfico não compete neutralidade para aqueles que leem o espaço sob suas lentes. Tal conhecimento pode gerar conflitos seja por resistência - em confronto ao que está posto - seja pelo uso em favor de instituir hegemonia e uma forma de organização do espaço para servir a interesses determinados. $\mathrm{Ou}$ seja, estabelece que o espaço geográfico é fundamentalmente moldado pela geopolítica. Entenda-se, então, que a geografia auxilia na compreensão complexa do ambiente, favorecendo uma percepção crítica da organização do espaço considerando para isso os 
atributos físico-naturais e também socioculturais que o constituem, como tem sido determinado pela globalização. Essa organização com intencionalidades implícitas ou explícitas ocasiona conflitos dos homens e mulheres entre si, assim como dos homens e mulheres, dialeticamente, com o seu meio, o que tem como reflexo o atual cenário de crise ambiental e civilizatória em que nos encontramos.

A temática abordada no terceiro capítulo corresponde dialogicamente a estas questões demonstrando como se tem valorado a natureza, ou seja, "os fluxos de benefícios tangíveis e intangíveis provenientes de todos os recursos naturais que são utilizados e modificados pela ação antrópica", pelos principais atores ligados ao mercado, ao Estado e à sociedade. Portanto, põe em questão a consideração dos valores de uso e de troca das amenidades proporcionadas pelos fluxos naturais, destacando a monetização do uso da natureza a fim de dotá-la de materialidade, mensurabilidade. O que evidencia o fetichismo envolvido na mercadificação da natureza, de suas amenidades. Considera-se, assim, que esse movimento relega por um lado os aspectos de nossa ligação essencial com o ambiente que compomos, mas também, oportuniza mensurar através do capital os impactos causados por nossas ações a fim de conter e controlar os aspectos negativos de nossa exploração. Pode-se, então, compreender esta dinâmica com a criticidade provida pelo olhar geográfico - como demonstrado no primeiro capítulo -, como também considerando a intrínseca relação entre a crise ambiental e a globalização sob os ditames do capitalismo neoliberal, evidenciada no segundo capítulo.

Observa-se esta valoração, portanto, sob um aspecto positivo com o propósito de estabelecer - através da dimensão econômica que se sobrepõe às demais - formas de controle da qualidade ambiental para que haja bem-estar social e econômico, sob os aspectos de uma sustentabilidade, considerando como partícipes todos os atores para as tomadas de decisões, democraticamente. Mas também sob um aspecto negativo, de ampliar as possibilidades do business environment condição que pode demonstrar o modus operandi das estratégias de uma globalização pautada sobremaneira por questões financeiras em detrimento das pessoas, do ambiente, de uma "sustentabilidade", o que se revela incrivelmente paradoxal como demonstrado no segundo capítulo desta obra.

Ainda considerando as discussões do terceiro capítulo, em sua última seção, pode-se destacar sua coadunação à ideia do Desenvolvimento à escala Humana concebida por Maxneef (2012). Tal desenvolvimento se concentra na satisfação das necessidades humanas fundamentais, na articulação orgânica dos seres humanos com a natureza e com a tecnologia, 
"na interação de processos globais com comportamentos locais, do pessoal com o social, do planejamento com a autonomia e da sociedade civil com o estado" (Ibidem, p. 22). Assim como, com a ideia de uma outra globalização desenvolvida por Santos (2001). Visões estas que precisam ser ressaltadas, defendidas e verdadeiramente consideradas para uma mudança positiva.

O que, por sua vez, inter-relaciona-se intimamente com a discussão do quarto capítulo em que se abordam os contextos de surgimento e avanço dos movimentos ambientalistas, da concepção do ecodesenvolvimento ao desenvolvimento sustentável e das discussões políticas acerca dos limites da exploração dos recursos naturais relacionados ao crescimento econômico em escala global. Nesse sentido, evidencia que a ordem capitalista que se figurou hegemônica propiciou o olhar fragmentado, um exacerbado tecnicismo e uma compreensão instrumental do ambiente, o que metabolizou as críticas ao modelo de crescimento em vigor. Então, foi através dos movimentos sociais e de uma considerável produção teórica acerca das discussões sobre um outro desenvolvimento, sustentável, sustentado, que ascende uma pressão para inserção da discussão ambiental na agenda política de órgãos multilaterais. Exigindo-se engajamento institucional dos países, regulamentações, políticas e planos que respondessem às preocupações com a conservação do planeta, trazendo também importantes debates acerca do movimento de globalização que então se delineava.

A discussão ambiental, então, enraizou-se no discurso político oportunizando o surgimento de partidos que consideram a questão ambiental como cerne para a atuação política, os chamados "partidos verdes". Entretanto, apesar dos esforços, muitas destas forças foram aglutinadas em favor de práticas alinhadas à corrente ideológica de uma dinâmica capitalista perniciosa, recrudescendo a degradação do ambiente. Como se pode observar nas reflexões propostas pelo terceiro capítulo do livro sobre a valoração do capital natural. Deste modo, observando criticamente o processo de globalização, seus aspectos políticos, interesses e as disputas que ensejam, cabe-nos reflexão sobre a complexidade dos desafios postos à superação da crise que nos encontramos.

Denudadas nossas fragilidades, nossa frágil capacidade de compreensão total da realidade do espaço geográfico, do ambiente e seus territórios, entretanto, buscando evoluir em algum sentido - resta comprovado seguir ampliando as vozes da razão e iluminando o saber por meio dos valores éticos, dos princípios universais do bem, do justo, dos conhecimentos práticos e dos saberes tradicionais para ampliar nossa compreensão de unidade. Dessa forma, nossas pequenas contribuições serão as bases, uma herança positiva, 
àqueles que serão os protagonistas e as protagonistas da construção de uma realidade que insistimos em acreditar possível e que se erguerá, porque não há outro caminho possível. Acreditemos sempre. Sigamos tecendo os elos!

[...] você jamais compreenderá o amor, a não ser que você se apaixone. Isto é válido para todo o sistema vivo. Não adianta você tentar compreender alguma coisa da qual você não faça parte. Sendo assim, como poderemos compreender uma sociedade, um mundo, um planeta, uma biosfera, se nos desconectarmos deles? (MAX-NEEF, 2012, p. 104-105).

\section{REFERÊNCIAS}

LEFF, Enrique. Racionalidad Ambiental: la reapropiación social de la naturaleza. México: Siglo XXI, 2004.

MAX-NEEF, Manfred A. Desenvolvimento à Escala Humana: concepção, aplicação e reflexos posteriores. Trad.: Rede Viva. Blumenau: Edifurb. 2012. (Sociedade e Ambiente, v. 06).

\section{ORGANIZAÇÃO DAS NAÇÕES UNIDAS (ONU), 2018. World Urbanization Prospects (Perspectivas da Urbanização Mundial). Disponível em: <https://www.un.org/en/events/citiesday/assets/pdf/the_worlds_cities_in_2018_data_booklet. pdf $>$ Acesso em 21 jan. 2019.}

PONTES, Bruno A. N. M. Desenvolvimento e governança ambiental: em busca de uma outra práxis na dinâmica territorial da "reserva" do Paiva - PE. Dissertação (mestrado) Universidade Federal de Pernambuco, CFCH. Programa de Pós-Graduação em Desenvolvimento e Meio Ambiente, Recife, 2017.

PORTO-GONÇALVES, Carlos Walter. Os (Des)Caminhos do Meio Ambiente. 15 a ed. São Paulo: Contexto, 2013.

SANTOS, Milton. Por uma outra globalização: do pensamento único à consciência universal. $6^{\mathrm{a}}$ ed. Rio de Janeiro: Record, 2001. 2006.

A Natureza do Espaço: técnica e tempo, razão e emoção. $4^{a}$ ed. São Paulo: EdUSP,

SWYNGEDOUW, Erik. A cidade como um híbrido: natureza, sociedade e "urbanizaçãociborgue". In: ACSELRAD, Henri (org.). A duração das Cidades: sustentabilidade e risco nas políticas urbanas. $2^{a}$ ed. Rio de Janeiro: Lamparina, 2009. pp. 99-120. 


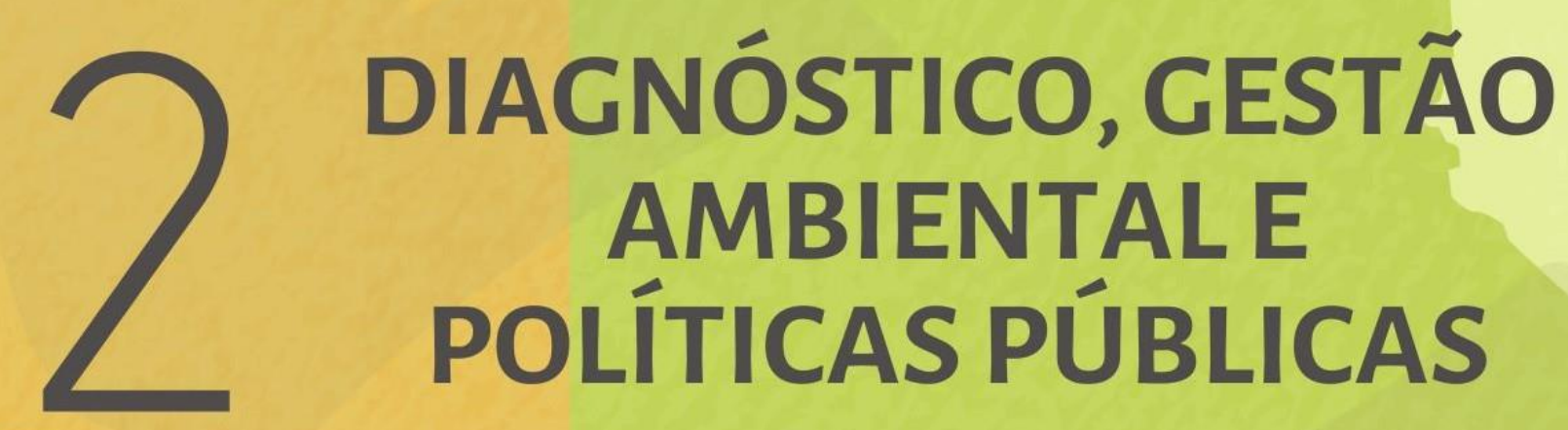




\title{
DIAGNÓSTICO SOCIOAMBIENTAL DO DELTA DO PARNAÍBA NA REGIÃO LITORÂNEA DO PIAUÍ-BRASIL
}

\author{
João Pinto Cabral Neto ${ }^{21}$ \\ Flávia Regina Sobral Feitosa ${ }^{21}$ \\ Wagner José de Aguiar ${ }^{21}$ \\ Bruno Augusto Nogueira Monteiro Pontes ${ }^{21}$
}

\section{INTRODUÇÃO}

O aumento dos impactos ambientais negativos vem se tornando cada vez mais uma das grandes preocupações de âmbito global, em função da sua potencialidade de causar danos ambientais e o empobrecimento dos recursos naturais.

Locais turísticos, como praias e rios, envolvem aglomerações de pessoas e oferecem serviços e atividades potencialmente impactantes, ou seja, são passíveis de problemáticas ligadas à poluição. A poluição e deposição de resíduos de maneira irregular podem comprometer a sustentabilidade turística, a integridade do meio ambiente, a saúde e o bemestar da população. Conforme Gregory (1999 apud ARAÚJO, 1999). Pode-se citar os seguintes impactos: perda estética do local, aprisionamento de animais e perigos de ingestão, danos aos pescadores, etc.

Entre os locais turísticos vulneráveis à problemática em questão pode-se citar o delta do Parnaíba, localizado entre os estados do Piauí e Maranhão. Por apresentar diversos atrativos naturais, de recreação e lazer, atrai um grande número de turistas durante todo o ano, representando um dos principais destinos turísticos do estado.

O delta do rio Parnaíba foi descoberto quando, há mais de 420 anos atrás, um navegante português Nicolau de Resende perdeu toneladas de ouro no litoral do Nordeste do

\footnotetext{
${ }^{21}$ Discentes de Doutorado do Programa de Pós-graduação em Desenvolvimento e Meio Ambiente (PRODEMA) da Universidade Federal de Pernambuco (UFPE), e-mail para contato: cabralneto7@ hotmail.com.
} 
Brasil, próximo à foz do Rio Parnaíba, que divide os Estados do Piauí e Maranhão. Por 16 anos, ele tentou, em vão, resgatar sua preciosa carga. E embora não a tenha encontrado, acabou achando um tesouro ainda maior, "um grande rio em forma de arquipélago verdejante que desemboca no Atlântico" (SILVA, 2004, p. 30).

Assim, esse estuário ecológico localiza-se ao norte do Piauí, na divisa do estado do Maranhão, na foz do rio Parnaíba, estendendo-se por $2.750 \mathrm{~km}^{2}$, sendo $65 \%$ pertencentes ao Maranhão e $35 \%$ ao Piauí. E a bacia do rio Parnaíba, apresenta-se como a principal bacia hidrográfica nordestina, possuindo $1.485 \mathrm{Km}$ de extensão da sua nascente até a foz, numa área de $342.988 \mathrm{Km}^{2}$ (ARAÚJO, 2006).

Diante o exposto, esse capítulo objetiva diagnosticar os impactos socioambientais ocasionados no delta do parnaíba na região litorânea do Piauí-Brasil, sugerindo práticas sustentáveis e políticas que sejam capazes de minimizar as degradações levantadas.

\section{REFERENCIAL TEÓRICO}

A formação de deltas é um fenômeno raro, existindo no mundo apenas três à mar aberto: o do rio Parnaíba no Brasil, o do rio Nilo na África e o de Mekong, no Vietnã. Além de ser um dos três existentes no mundo, o Delta do Parnaíba é o único delta à mar aberto das Américas. Possui uma configuração que se assemelha a uma mão aberta, onde os cinco dedos (braços dos rios) representam as barras de Tutóia, Caju, Melancieira, Canárias e Igaraçu (BRASIL, 2008).

Os deltas são considerados "santuários ecológicos", pela grande biodiversidade, reservas de manguezais, campos de dunas, praias com flora e fauna bastante diversificadas, o que faz do local um grande potencial turístico (OLIVEIRA; SILVA, 2016). Para sua preservação e conservação foram constituídas uma Área de Proteção Ambiental (APA) e uma Reserva Extrativista (RESEX), como forma de regulamentar e controlar o uso e a ocupação na região, devido às suas fragilidades ambientais.

A APA do delta do Parnaíba é uma unidade de conservação, com uma porção marítima e outra continental, englobando os municípios de Parnaíba, Ilha Grande, Cajueiro da Praia e Luís Correia, no Piauí; Barroquinha e Chaval, no Ceará; Araioses, Água Doce, Tutóia e Paulino Neves, no Maranhão (BRASIL, 2008a).

Essa APA é extensa e formada por terras públicas e privada, apresentando certo grau de ocupação humana, pois possui atributos abióticos, bióticos, estéticos ou culturais, imprescindíveis para o bem-estar das populações locais. Possui como objetivo primordial 
proteger a diversidade biológica, disciplinar o processo de ocupação e assegurar a sustentabilidade do uso dos recursos naturais, tendo como principais formas de usos a visitação pública e pesquisa (áreas públicas). (BRASIL, 2008a).

Já a RESEX Marinha Delta do Parnaíba foi criada pelo Decreto Federal de 16 de novembro de 2000, a partir de solicitação de 3.600 famílias; sendo composta por 3 municípios: Ilha Grande de Santa Izabel (PI), Araióses e Água Doce (MA). É considerada uma área de interesse ecológico e social, servindo como meio de exploração autossustentável, já que é utilizada por populações extrativistas (área de domínio público, com concessão de uso às comunidades tradicionais), para agricultura de subsistência e criação de animais de pequeno porte.

A criação dessa reserva visa proteger os meios de vida e a cultura dessas populações e assegurar o uso sustentável dos recursos naturais. Assim, as formas de usos básicos da RESEX são: visitação pública (conforme Plano de Manejo) e pesquisa (autorização), sendo proibida a exploração mineral e caça amadorística e profissional.

O delta do Parnaíba por se tratar de um estuário, é uma área de reprodução de diversas espécies como o caranguejo-seca (ucides cordalus), guaiamum (cordiosomo quanhami), siri (callinectis sapidus), camarão branco (Panaeus shimiti), além de várias espécies de peixes, répteis e aves (SILVA, 2004). Devido a esse vasto potencial biótico a pesca artesanal é uma fonte de renda para a subsistência de cerca de 5 mil famílias (BRASIL, 2001) e a comunidade pesqueira ainda explora comercialmente à cata do carangueço-uça (Ucides cordatus), fornecendo cerca de 18t/semana do crustáceo para a cidade de Fortaleza (MAGALHÃES, 2007).

Além disso, a beleza cénica faz do Delta do Parnaíba um local muito requisitado pelos turistas, tanto é que essa região, foi eleita em 2009 o melhor roteiro turístico do Brasil pelo Ministério do Turismo. No entanto, paradoxalmente, possuía um dos piores IDH's do País, segundo o Plano de Desenvolvimento Sustentável da Região Turística do Meio-Norte (BRASIL, 2009), apresentando uma composição econômica precária, assentada numa atividade agrária de subsistência e de baixa produtividade (Idem).

Esse cenário aponta para uma atividade turística assentada numa lógica da economia de mercado, gerando o emprego da força de trabalho local de modo precário, com baixas remunerações. Já que, muitos dos trabalhadores da atividade turística, atualmente, eram trabalhadores rurais que passaram a exercer atividades como barqueiros, guias ou produzindo 
e comercializando artesanato. Observa-se, ainda, a existência de uma série de impactos ambientais relacionados a estas atividades.

\section{METODOLOGIA}

O estudo foi realizado no município de Parnaíba, também conhecida como a capital do "delta" e também na cidade de Ilha Grande de Santa Isabel. O clima dessas regiões é quente, seco, com temperaturas que variam de $20^{\circ}$ a $32^{\circ} \mathrm{C}$ (SILVA, 2004).

Parnaíba é um município de 150.201 habitantes (IBGE, 2016), situando-se às margens do rio Igaraçu, a $330 \mathrm{~km}$ de Teresina. Economicamente, o Parnaíba é a segunda maior cidade do Piauí, possuindo IDHM, em 2010, de 0,687, portanto, um índice de desenvolvimento humano considerado médio. O índice de gini, que mede o grau de concentração de renda sendo 0 situação de total igualdade e 1 situação de total desigualdade, deste município é de 0,57, em 2010 (PNUD, 2013).

O município Ilha Grande possui aproximadamente 9.242 pessoas (IBGE, 2016) apresenta um IDHM de 0,563, considerado baixo e seu índice de gini é de 0,51 (IBE, 2010), o que reflete a menor dinâmica socioeconômica do município.

A população de Parnaíba e Ilha Grande apresentam salário médio mensal, no ano de 2014, 1,8 e 1,7 salário mínimo. Vale ressaltar que houve a ascensão no valor do salário mínimo no período de 2010 a 2016 num percentual de 11\% (BRASIL, 2016). Logo, a renda média mensal é considerada baixa. Ambos os municípios compõem a bacia do rio Parnaíba, deste modo, suas dinâmicas socioeconômicas advêm, em grande medida, da exploração deste rio, sobretudo em Ilha Grande.

\subsection{Procedimentos metodológicos}

Para levantamento dos impactos observados a partir da análise dos aspectos físiconaturais foram adotados os seguintes procedimentos:

Para análise dos impactos ambientais foi realizada uma visita de campo na qual foram fotografadas as evidências de impactos, mostrando o processo de erosão sofrido pelas dunas, a ocupação urbana, a perda de vegetação nativa, dentre outros aspectos.

Já, para detecção dos impactos ocorridos a partir dos aspectos socioeconômicos foram adotados os seguintes procedimentos: 
- Pesquisa bibliográfica acerca dos impactos ambientais quanto ao uso e ocupação na região do delta do rio Parnaíba, especificamente nos municípios de Parnaíba e Ilha Grande;

- Trabalho de campo para observação e caracterização in loco dos impactos socioambientais detectados, mediante realização de entrevistas com 4 moradores da região, selecionados de maneira aleatória.

A seguir, foi realizado um levantamento preliminar da dinâmica socioambiental de 05 (cinco) pontos considerados de áreas frágeis dos municípios analisados, que foram: Porto das Barcas; Porto dos Tatus; Praia dos Poldos; Igarapé dos Periquitos e Dunas do "Morro Branco".

Para elencar e descrever esses impactos foi adotado o método de listagem de controle (check list), onde se efetuou a enumeração dos impactos mais relevantes de acordo com as observações realizadas in loco e entrevistas informais realizadas com os moradores de Ilha grande - Parnaíba. A partir desta coleta de dados foi possível caracterizar a dinâmica ambiental desses munícipios e apontar alguns dos impactos ambientais decorrentes do atual uso e ocupação nestes territórios.

\section{RESULTADOS E DISCUSSÃO}

Os primeiros levantamentos de campo possibilitaram identificar as seguintes dinâmicas da paisagem na região do delta do Parnaíba:

O Porto das Barcas com destaque ao rio Igaraçu é a porta de entrada ao delta do Parnaíba. Ele foi um importante local para a formação do território piauiense, devido aos seus antigos armazéns utilizados para estocar cera de carnaúba, castanha, couro e babaçu para exportação, através do rio Igaraçu, até chegar ao oceano Atlântico. 
Figura 01 (a; b) - Porto das Barcas (a) e o Rio Igaraçu (b), em Parnaíba

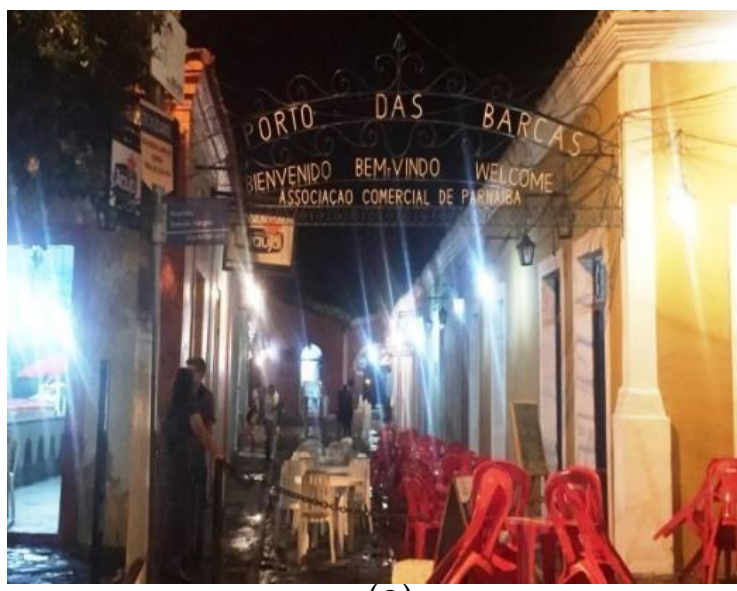

(a)

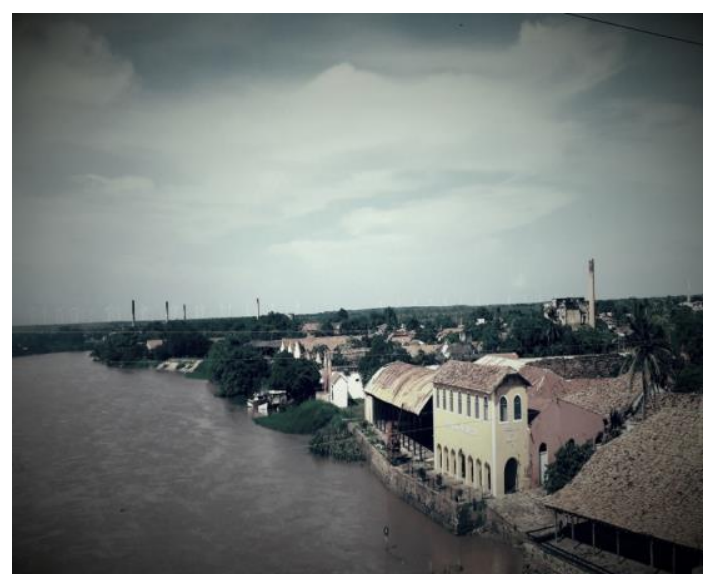

(b)

Foto: Os autores (2017).

Porto dos Tatus, localizado em Ilha Grande de Santa Isabel, a cerca de $11 \mathrm{~km}$ de Parnaíba. É considerado o principal porto de embarque em direção ao delta do rio Parnaíba. No local encontram-se bares e restaurantes que ofertam comidas típicas da região. É importante destacar as comunidades locais que vivem, sobretudo, da cata de caranguejos, mariscos, da pesca artesanal, da coleta de frutos e do artesanato.

Sendo esta, também, a região de morada de diversos ribeirinhos, foi o local onde mais foram constatados lançamentos de esgotos residenciais, sem tratamento prévio, diretamente no curso do rio, além da prática de lavagem de roupa suja com o uso de sabão, também no leito do mesmo.

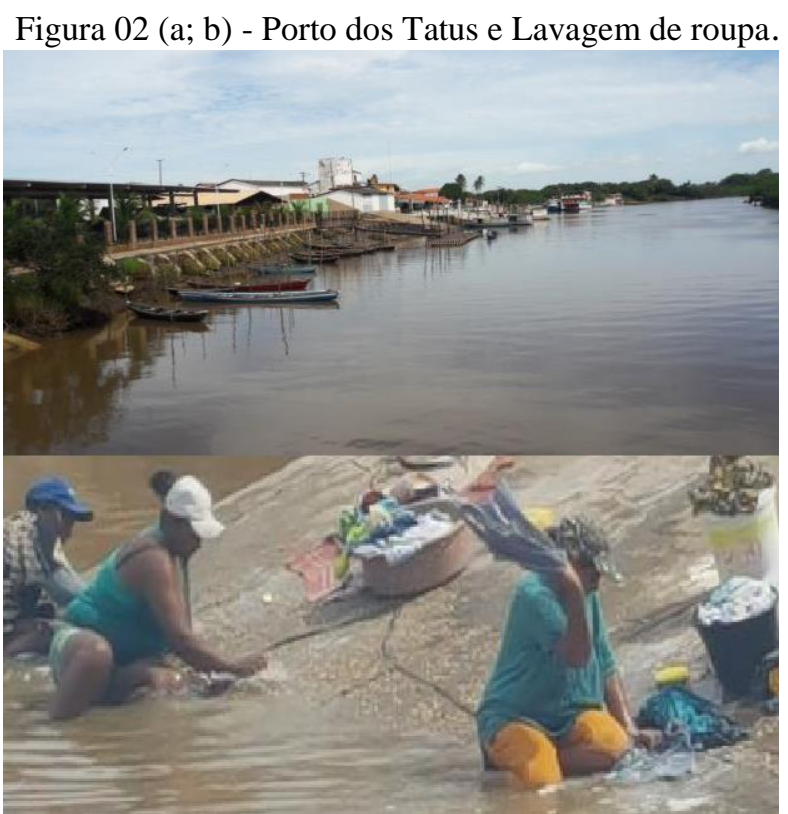

Foto: Os autores (2017). (a)

(b) 
Praia dos Poldros, situado em Parnaíba. É um local onde são atracados os barcos que realizam passeios ao delta do rio Parnaíba com os turistas. Pode-se observar o descarte inadequado de resíduos sólidos, bem como o tráfego de quadrículos. É um ambiente flúviomarinho que se destaca pelo encontro da água doce (rio Parnaíba) com a água salgada (oceano Atlântico). Devido a maior presença de atividades turísticas, foram registradas diversas evidências de poluição da orla, devido à falta de um programa de coleta ou, sequer, de recipientes de depósito de lixo distribuídos pela praia.

Ademais, a ingestão de resíduos sólidos dispostos inadequadamente acaba acarretando na morte de animais marinhos, como é o caso das tartarugas marinhas.

Figura 03 (a; b) - Praia dos Poldros (a) e resíduos orgânicos jogados na Praia, em Parnaíba (b).

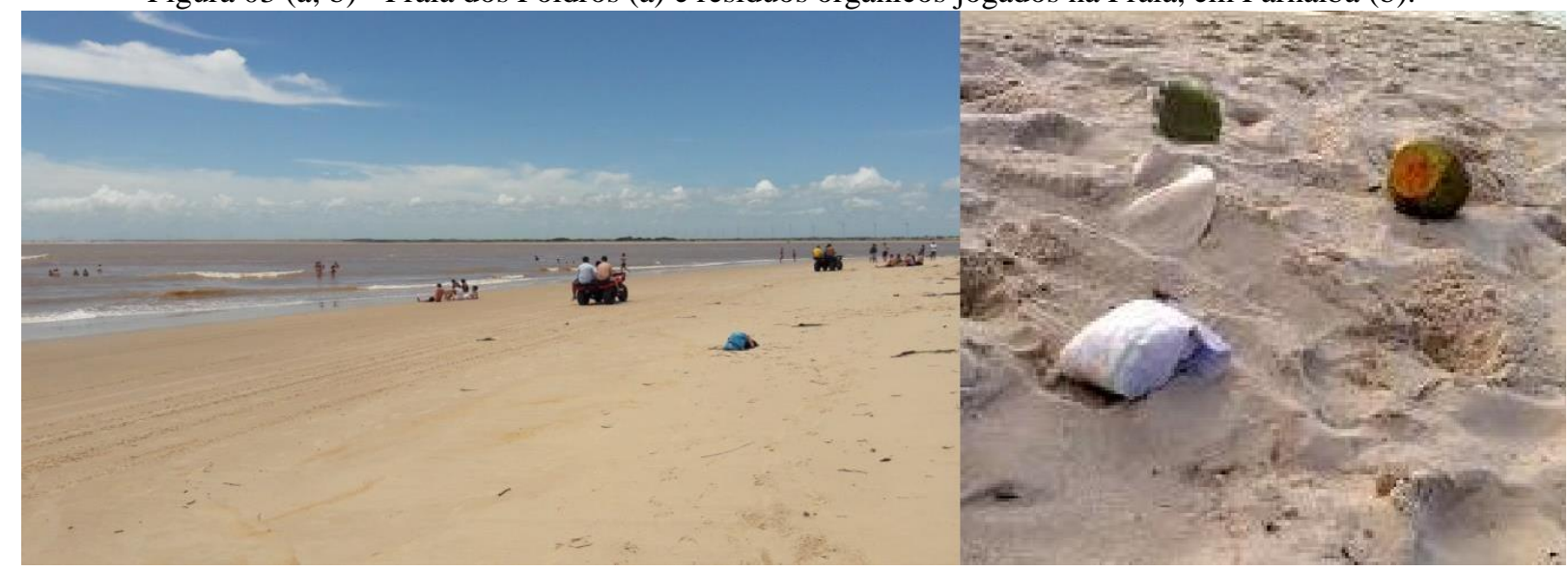

(a)

(b)

Foto: Os autores (2017).

Igarapé dos Periquitos, a cerca de 6 km de Parnaíba, possui vegetação de mangues com exuberantes raízes aéreas. É um local utilizado pelos caiçaras para coleta do caranguejo (sararás e uçás). De acordo com o guia do barco, estima-se que anualmente são retirados cerca de vinte milhões de caranguejos na área do delta do Parnaíba, envolvendo cerca de cinco mil catadores da região. 
Figura 04 (a; b) - Igarapé dos Periquitos em Parnaíba (a) e Cata de caranguejo na região de mangue do delta do Parnaíba (b).

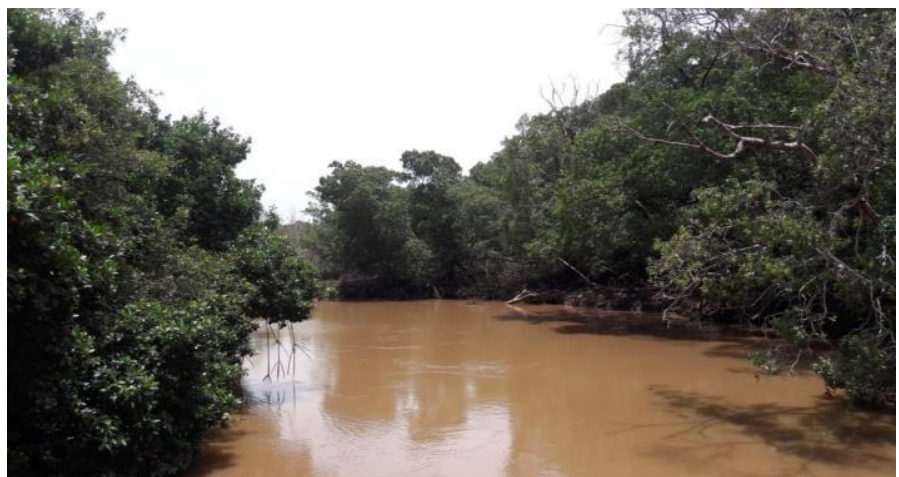

(a)

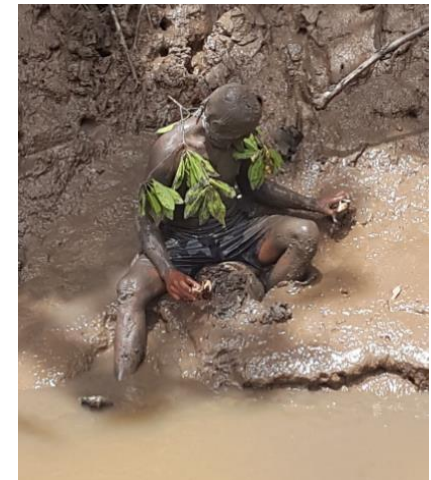

(b)

Foto: Os autores (2017).

Dunas do "Morro Branco", no município de Ilha Grande de Santa Isabel, resultantes da sedimentação eólica, formando várias lagoas de água doce que surgem em decorrência das chuvas. As dunas do "Morro Branco" ficam próximas ao Porto dos Tatus. Percebeu-se a deposição de resíduos sólidos, decorrente da atividade turística realizada pelos passeios ao delta do rio Parnaíba. Sendo ainda uma região onde se há a exploração do potencial eólico através da geração de energia.

Figura 05 (a; b; c) - Dunas do Morro Branco (Piauí).

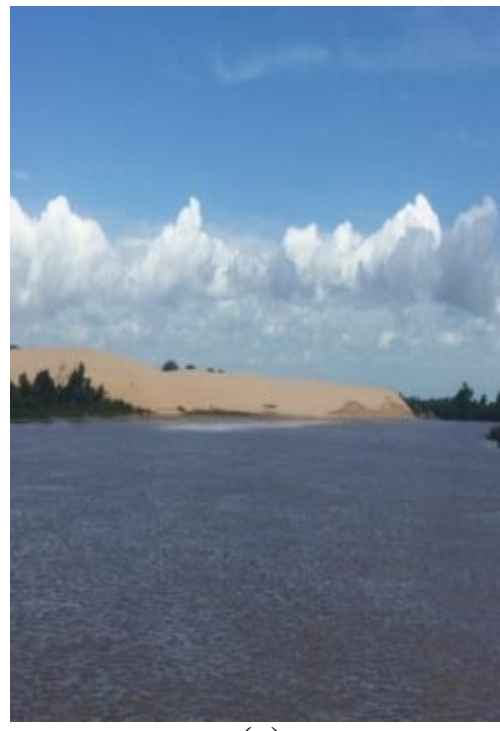

(a)

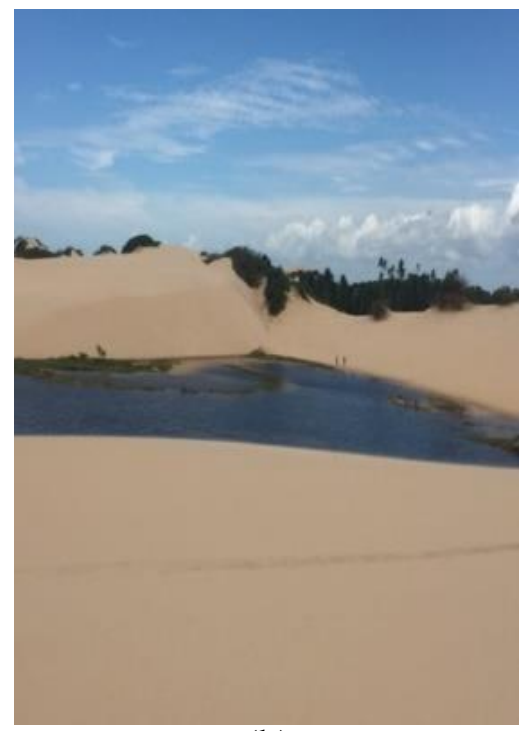

(b)

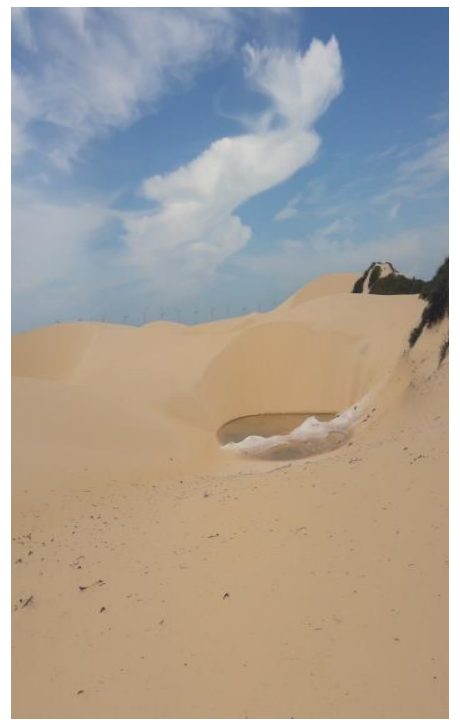

(c)

Foto: Os autores (2017). 
Figura 06 (a; b; c) - Geração Eólica nas Dunas do Morro Branco.

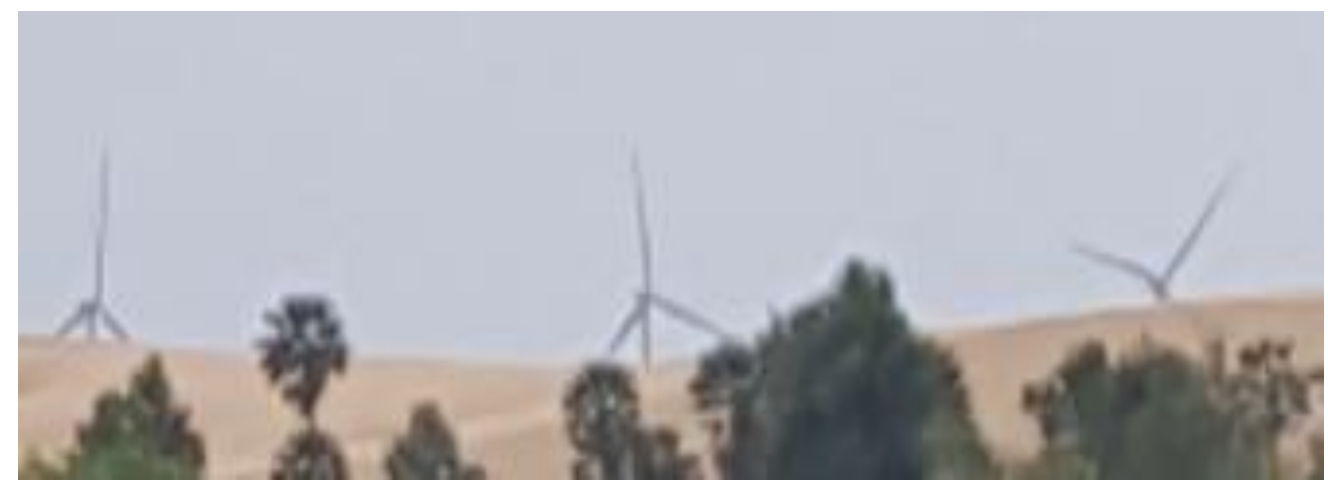

Foto: Os autores (2017).

A região foi caracterizada como sendo uma Planície Flúvio Lacustre. Para essa identificação, foram utilizados como indicadores a presença de carnaubeiras, que é uma cultura xerófila típica de zonas de alagamento (Figura 07).

Figura 07 - Planície Flúvio Lacustre

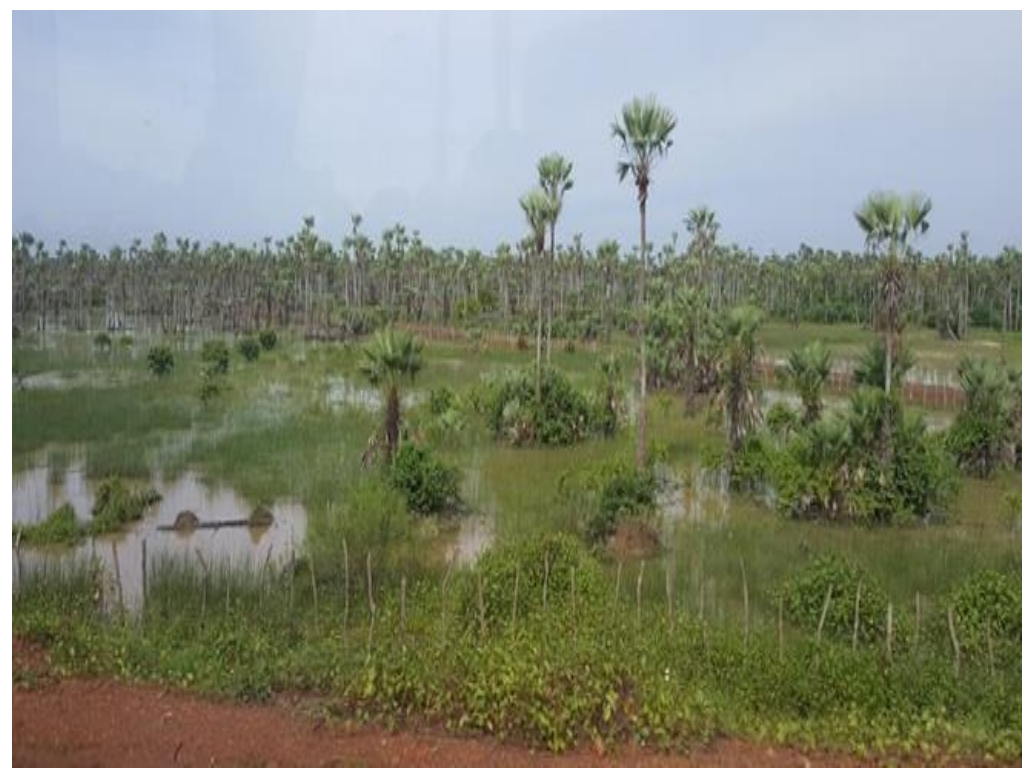

Foto: Os autores (2017).

Observou-se ainda in loco que está ocorrendo um avanço da ocupação sobre a área da APA e atividades econômicas como a pesca, o extrativismo vegetal e de caranguejo, a rizicultura, a agricultura de subsistência, a pecuária extensiva e o turismo estão sendo intensificados. Essas atividades de uso e ocupação na área têm aumentado às ameaças quanto à degradação ambiental e à dilapidação do patrimônio natural (BRASIL, 2008). 
Por isso, esforços foram enviados para que houvesse a correta gestão e conservação da região deltaica, como o projeto de Zoneamento Ecológico-Econômico (ZEE) do Baixo Parnaíba, coordenado pelo Ministério do Meio Ambiente, em 2008.

Além disso, tal estudo apontou áreas frágeis, numa proporção de $34 \%$ da área total do baixo Parnaíba (Figura 08):

Figura 08 - Fragilidade dos Sistemas Ambientais no baixo Parnaíba.

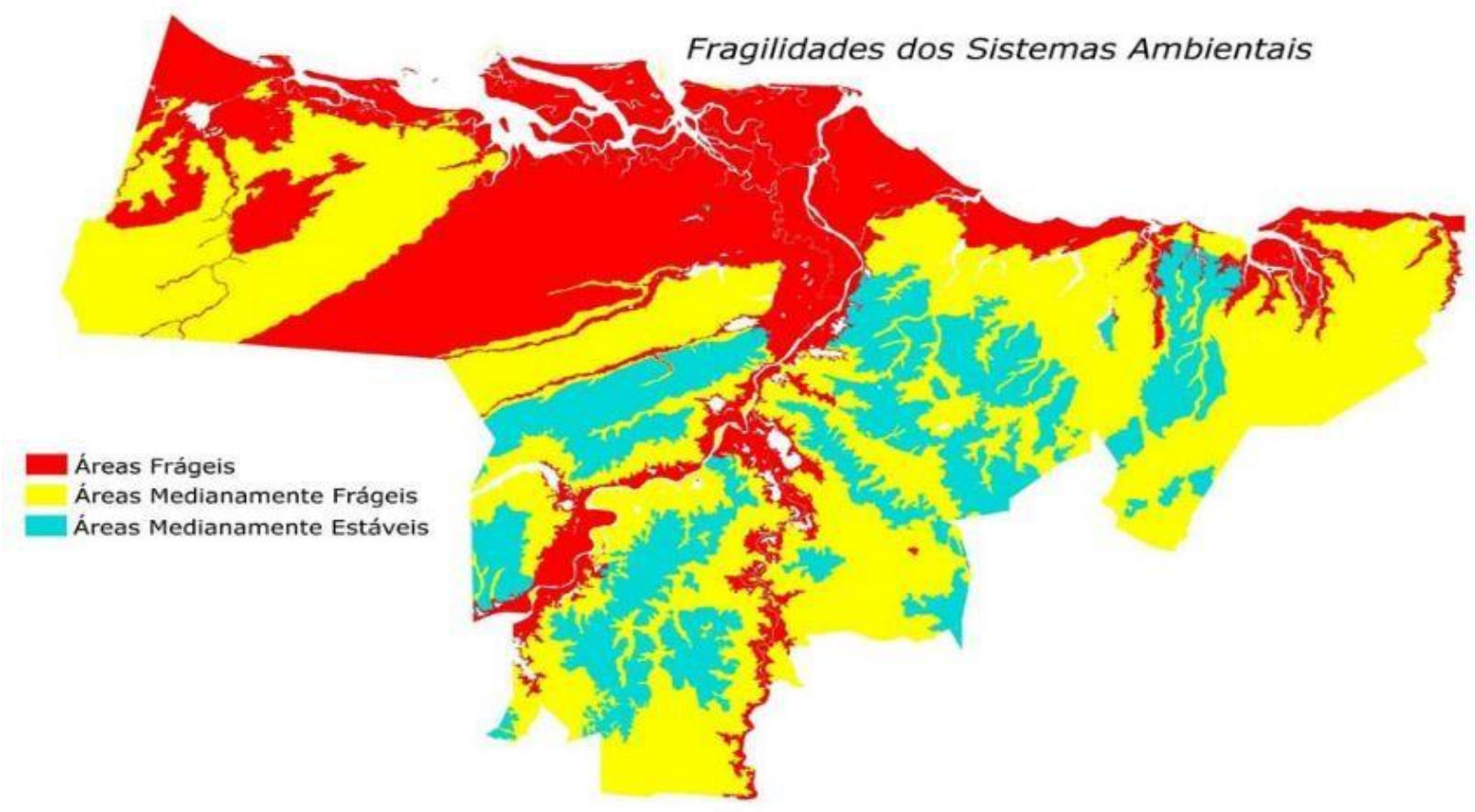

Fonte: MMA (2008).

Observou-se também que, a paisagem é compota principalmente por praias arenosas, campos de dunas, estuários, manguezais e lagoas costeiras e por isso um dos maiores problemas verificados na região do Delta está relacionado a ocupação desordenada da população em áreas frágeis e suscetíveis a degradação de seus recursos naturais, causando diferentes impactos e conflitos de uso.

Foram detectadas ainda na região, algumas atividades com grande potencial para causar impactos ambientais entre elas: a atividade pecuária extensiva, comprometendo ainda mais o solo, intensificando o assoreamento e podendo contaminar a água pelo ao uso de fertilizantes e pesticidas no cultivo de rações; o desmatamento; o cultivo de arroz, acarretando em intenso e indiscriminado uso das águas do rio; caça e pesca de crustáceos sem a devida fiscalização; assoreamento dos cursos d'água; sistema de saneamento deficitário, ocasionando 
poluição da água e do solo, através da deposição de esgoto e lixo; atividade turística desconexa com os territórios que compõem a região do delta.

Figura 09 - Ribeirinho em atividade de pesca.

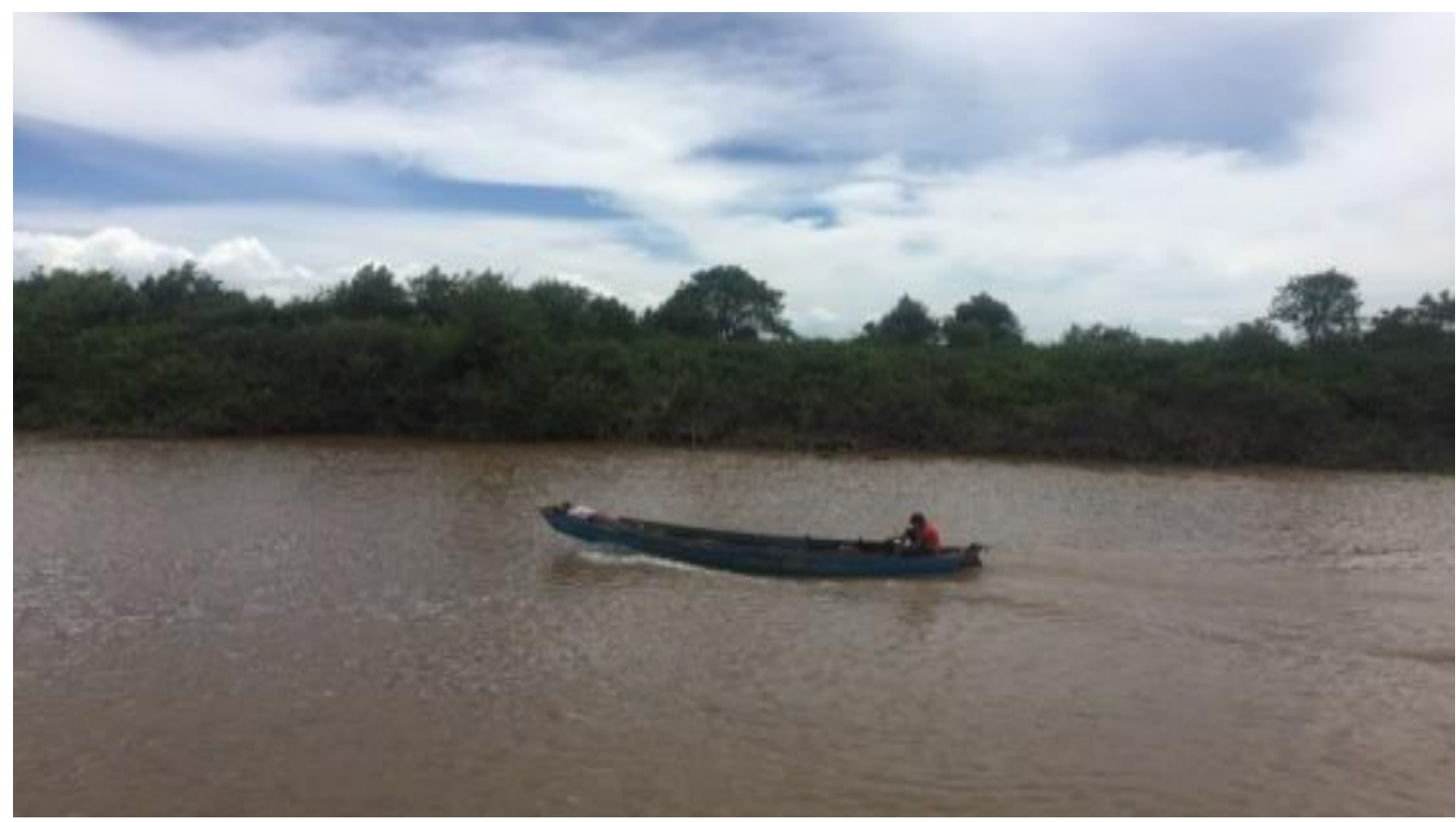

Foto: Os autores (2017).

Nesse sentido, Sánchez (2008, p.35) afirma que: “As taxas de erosão e degradação do ambiente variam muito de cultura para cultura e dependem também das práticas agrícolas usadas. (...) O corolário da erosão é o assoreamento dos corpos d'água, pois parte dos sedimentos transportados pela ação das águas fica retido no fundo de rios e lagos".

Além desses impactos, as entrevistas realizadas com moradores da região do Parnaíba e Ilha Grande possibilitaram evidenciar que a construção de casas em áreas de alagamento era uma prática cada vez mais comum da região, pois, por ser de Domínio da União, a prefeitura não exerce nenhum controle sobre esse crescimento e a ocupação desordenada.

Ressalta-se que, na região da Ilha Grande sequer possui um Plano Diretor e essa falta de ordenação territorial faz com que os moradores construam casas nas zonas de controle e esperem pela regularização de suas terras, pois não tem a obrigação de pagarem IPTU. Assim, vários dos moradores locais dão preferência por habitarem essa região, com a certeza de que posteriormente o título de posse lhes será concedido. 
Figura $10(a ; b ; c)$ - Ocupação em zona de alagamento pertencente à União

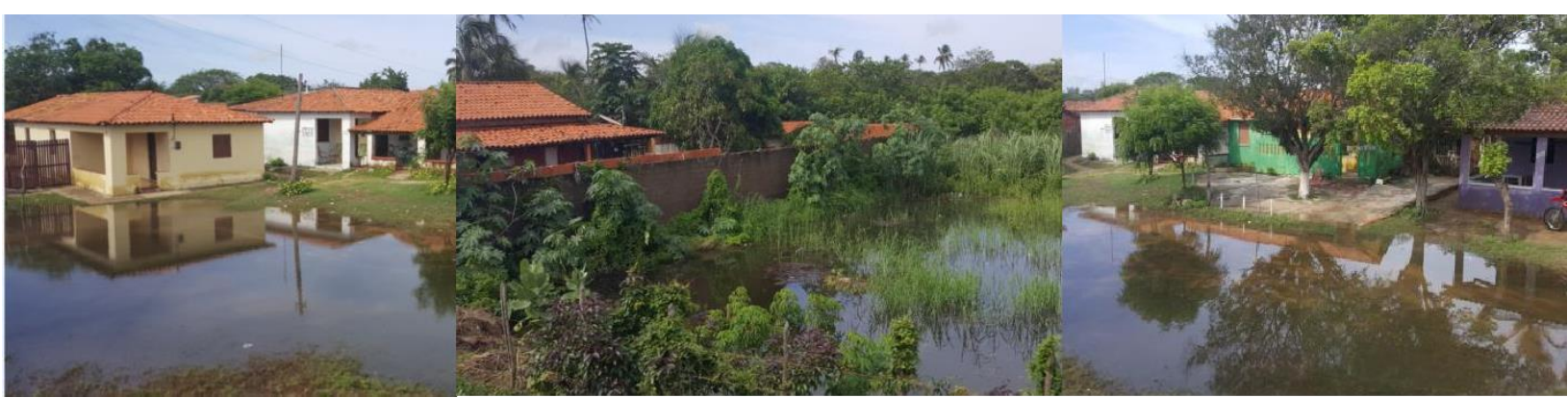

(a)

(b)

(c)

Foto: Os autores (2017).

Nesse sentido, Sánchez (2008, p.36) afirma que: “(...) a implantação de loteamentos urbanos eleva ainda mais as taxas de erosão, uma vez que os solos ficam diretamente expostos à ação da água da chuva e também dos ventos (...)”.

As falas dos moradores locais possibilitaram evidenciar também que a exploração do mangue-siriba (Avicennia germinans) e do mangue-preto (A. schaueriana) para a produção de peças de barcos e equipamentos de pesca (alta resistência a água) são frequentes. Já a madeira retirada do mangue-vermelho (Rhizophora mangle) é bastante usada na construção de casas e na extração de tinino (corante), além de seu uso medicinal, já que as cascas e folhas servem para o tratamento de hemorragias.

Outra forma de exploração da vegetação do mangue é o uso energético a fim de que seja produzido o carvão. Esse impacto soma-se a frequente substituição dos manguezais por roças de arroz e salinas, o que causa o empobrecimento do solo.

Figura 11 - Carnaubal nativo da região

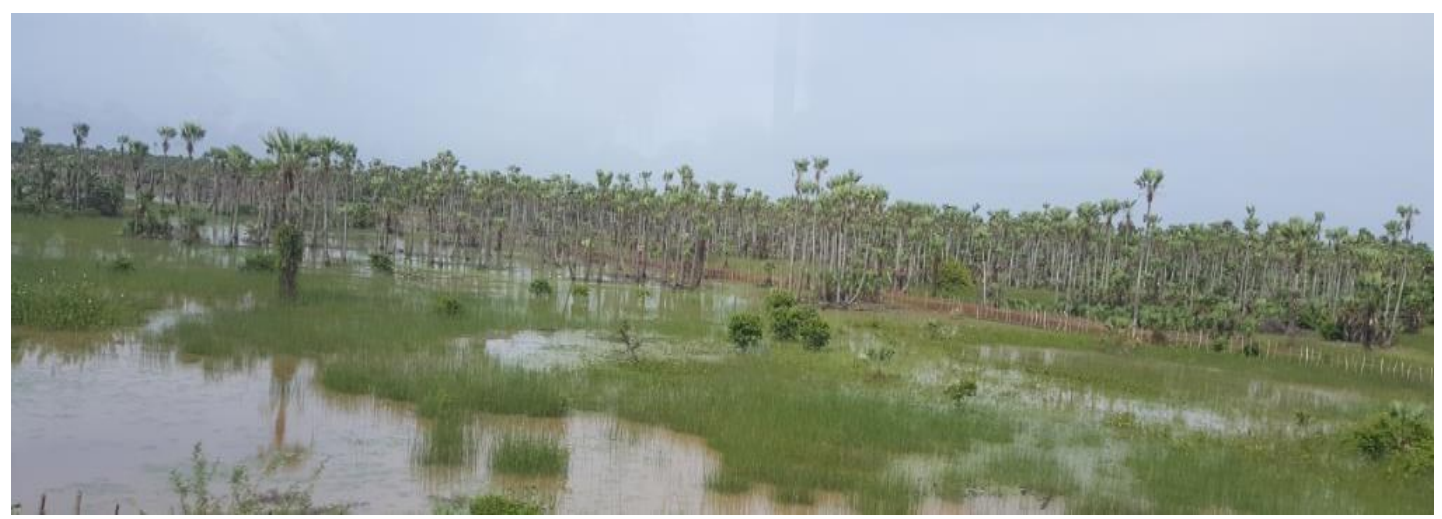

Foto: Os autores (2017). 
Ressalta-se, entretanto, que os manguezais são ecossistemas de alta produtividade, sendo fonte de alimento e sustento econômico de comunidades humanas litorâneas, agindo como protetor da costa contra erosão, filtro biológico, exportador de matéria orgânica para estuários, refúgio de vida silvestre, provendo abrigo e manutenção a rica e diversificada fauna associada, constituída principalmente de peixes, moluscos e crustáceos, que são valiosos patrimônios paisagísticos e bioecológicos (SILVA; SOUZA, 2006).

A partir do diagnóstico da área, pôde ser confeccionada a seguinte síntese dos impactos ambientais, bem como proposta algumas ações para mitigar esses danos (Quadro 1).

Quadro 1 - Diagnóstico da área de estudo.

\begin{tabular}{|c|c|c|c|c|}
\hline Meio & Categorias & Causas & Impactos & Medidas Mitigatórias \\
\hline \multirow{6}{*}{ Físico } & \multirow{3}{*}{ Solo } & Desmatamento/queimada; & $\begin{array}{c}\text { Perda de matéria } \\
\text { orgânica na camada } \\
\text { superficial do solo; }\end{array}$ & $\begin{array}{l}\text { Recuperação das áreas } \\
\text { degradadas; }\end{array}$ \\
\hline & & $\begin{array}{l}\text { Disposição irregular de } \\
\text { resíduos sólidos; }\end{array}$ & $\begin{array}{l}\text { Perda de fertilidade } \\
\text { do solo; }\end{array}$ & $\begin{array}{l}\text { Coleta e tratamento } \\
\text { adequado dos resíduos } \\
\text { sólidos; } \\
\end{array}$ \\
\hline & & Erosão e assoreamento; & $\begin{array}{c}\text { Compactação do } \\
\text { solo; }\end{array}$ & Manejo adequado do solo. \\
\hline & \multirow{2}{*}{$\mathrm{Ar}$} & $\begin{array}{c}\text { Aumento da } \\
\text { evapotranspiração. }\end{array}$ & Poluição visual. & $\begin{array}{l}\text { Eliminação das } \\
\text { queimadas; }\end{array}$ \\
\hline & & Queimada & $\begin{array}{c}\text { Poluição } \\
\text { atmosférica }\end{array}$ & $\begin{array}{l}\text { Recuperação das áreas } \\
\text { degradadas; }\end{array}$ \\
\hline & Água & $\begin{array}{c}\text { Lançamento de efluentes } \\
\text { sem tratamento }\end{array}$ & $\begin{array}{l}\text { Contaminação dos } \\
\text { recursos hídricos } \\
\end{array}$ & $\begin{array}{c}\text { Tratamento adequado dos } \\
\text { efluentes domésticos. }\end{array}$ \\
\hline \multirow{6}{*}{ Biótico } & \multirow{3}{*}{ Fauna } & \multirow{3}{*}{ Caça e pesca } & \multirow{3}{*}{$\begin{array}{c}\text { Perda da } \\
\text { biodiversidade }\end{array}$} & Punição aos caçadores \\
\hline & & & & Fiscalização ambiental \\
\hline & & & & $\begin{array}{c}\text { Manejo adequado da } \\
\text { pesca } \\
\end{array}$ \\
\hline & \multirow{3}{*}{ Flora } & $\begin{array}{c}\text { Extrativismo vegetal } \\
\text { (extração da carnaúba); } \\
\text { Plantio de arroz } \\
\text { (rizicultura) }\end{array}$ & $\begin{array}{c}\text { Perda da } \\
\text { biodiversidade }\end{array}$ & $\begin{array}{c}\text { Recuperação das áreas } \\
\text { degradadas }\end{array}$ \\
\hline & & $\begin{array}{c}\text { Desmatamento (pecuária) } \\
\text { e queimadas }\end{array}$ & \multirow{2}{*}{$\begin{array}{c}\text { Redução do } \\
\text { potencial genético }\end{array}$} & $\begin{array}{c}\text { Manejo adequado dos } \\
\text { recursos florestais e } \\
\text { agrícolas } \\
\end{array}$ \\
\hline & & $\begin{array}{l}\text { Ocorrência de espécies } \\
\text { invasoras }\end{array}$ & & $\begin{array}{c}\text { Utilização dos SAFs } \\
\text { (Sistemas Agroflorestais) }\end{array}$ \\
\hline \multirow{8}{*}{ Antrópico } & \multirow{5}{*}{$\begin{array}{l}\text { Geração de } \\
\text { Empregos e } \\
\text { renda }\end{array}$} & Artesanato; & \multirow{5}{*}{$\begin{array}{l}\text { Melhoria da cadeia } \\
\text { produtiva; } \\
\text { Melhores condições } \\
\text { de renda. }\end{array}$} & \multirow{5}{*}{$\begin{array}{l}\text { Fixação dos moradores em } \\
\text { sua localidade de origem }\end{array}$} \\
\hline & & Guiamento turístico; & & \\
\hline & & Hospedagem; & & \\
\hline & & Setor alimentício; & & \\
\hline & & Transporte marítimo & & \\
\hline & \multirow{3}{*}{$\begin{array}{l}\text { Vulnerabilidade } \\
\text { Sociais }\end{array}$} & $\begin{array}{l}\text { Violência; aumento das } \\
\text { drogas }\end{array}$ & \multirow{3}{*}{$\begin{array}{l}\text { Insegurança, } \\
\text { Aumento de } \\
\text { doenças. }\end{array}$} & \multirow{3}{*}{$\begin{array}{l}\text { Implantação de políticas } \\
\text { públicas de saúde e } \\
\text { educação. }\end{array}$} \\
\hline & & Prostituição; & & \\
\hline & & $\begin{array}{l}\text { Problemas de saúde } \\
\text { (aumento das DST's) }\end{array}$ & & \\
\hline
\end{tabular}

Fonte: Os autores (2017). 
Por fim, nos últimos anos, os municípios de Ilha Grande, Porto dos Tatus, Parnaíba e Porto das Barcas têm sido pontos estratégicos para a atividade turística, servindo de passagem para passeios de barcos organizados pelas agências turísticas locais para visitação à região do delta (Figura 12). Porém, a comunidade tem sido inserida precariamente nesta atividade, como dito, explorada pelo pagamento de baixos salários.

Figura 12 - Porto dos Tatus, em Ilha Grande.

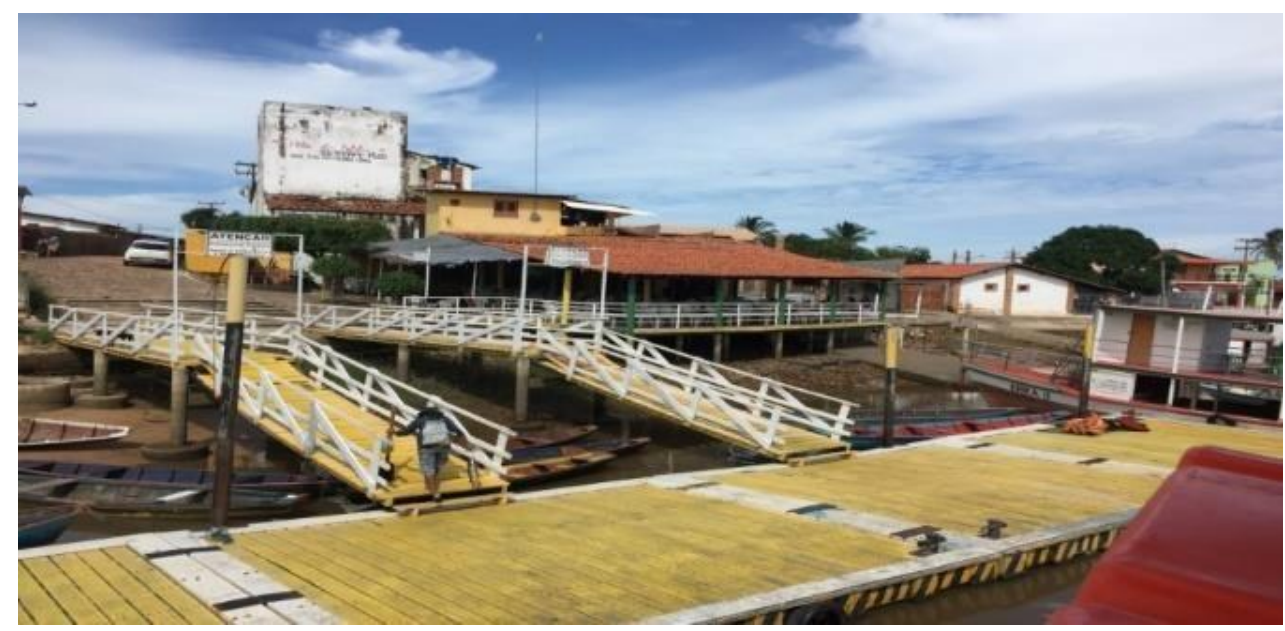

Foto: Os autores (2017).

Destarte, nestas áreas percebem-se alguns dos reflexos negativos da atividade turística realizada pela população local, quando não orientada, sem considerar suas territorialidades e quando os principais responsáveis pelas práticas não têm a consciência e identificação com o ambiente: inflação nos preços dos produtos locais, maior degradação dos recursos naturais, podendo impactar sobre a pesca local, recrudescer as desigualdades socioeconômicas e ocasionar fenômenos de homogeneização cultural.

Desta maneira, se faz necessário avaliar todo o conjunto de possibilidades de ações, observando a viabilidade técnica, ambiental e econômico-financeira, conforme estabelecido abaixo (Figura 13). 
Figura 13 - Mapa de gestão de resíduos integrada à educação ambiental

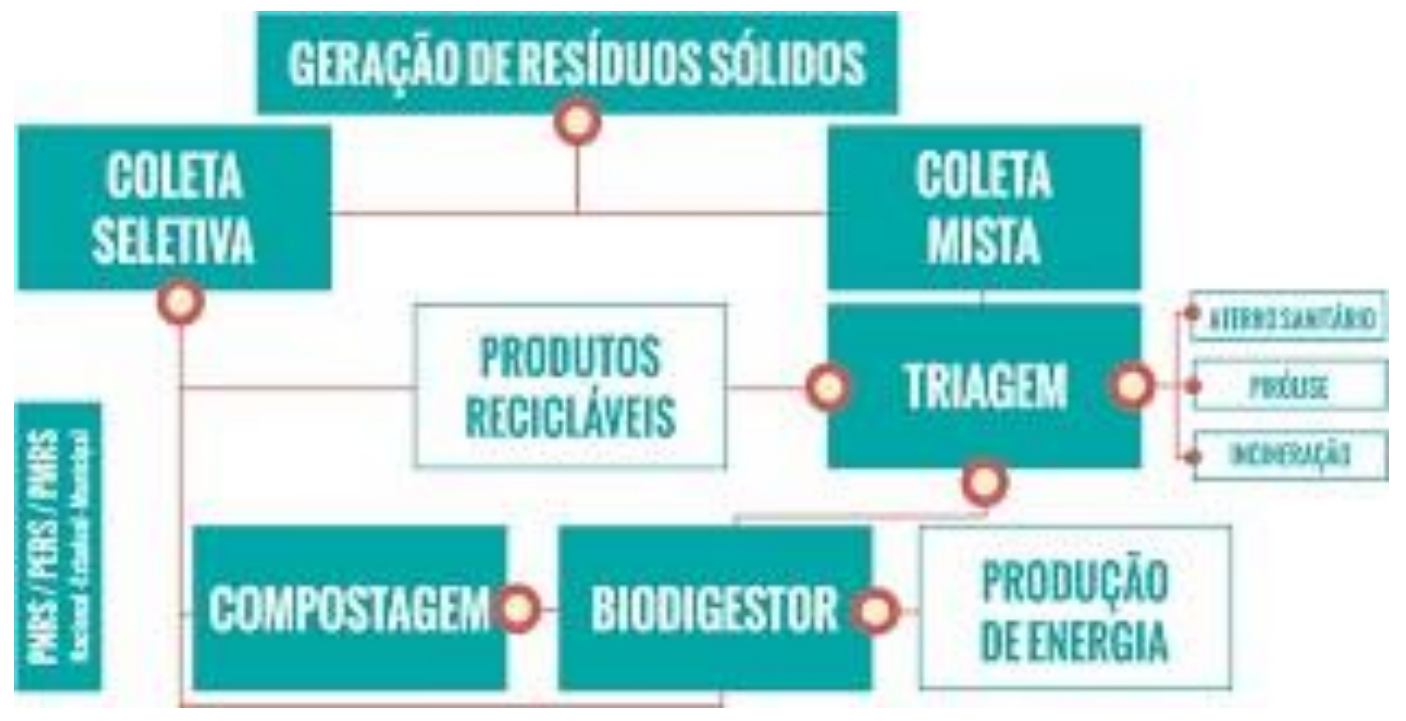

Fonte: IPT CEMPRE (1995).

Logo, o turismo nesta região, apresenta um duplo desafio: primeiro ser uma prática amigável com os recursos naturais, e segundo, gerar uma distribuição igual de seus benefícios (renda, geração do emprego, intercâmbio cultural, etc.). Para isso, a inclusão da comunidade no planejamento de atividades de turismo com a mobilização de ideias é necessária para criar ofertas de produtos e serviços por meio dos moradores, assim como o fornecimento de acomodações nativas que permitam à comunidade ter maior controle no uso da terra, como forma de conter as intervenções de investimentos privados externos que possam gerar estes tipos de externalidades negativas. Assim, a proposta da prática de um turismo comunitário, pensada e fornecida pela população local, poderia auxiliar na mitigação destes problemas.

\section{CONSIDERAÇÕES FINAIS}

Com a realização deste estudo de caso foi apresentado um panorama da situação dos impactos ambientais gerados por atividades turísticas e pela ocupação desordenada na região do delta do Parnaíba. Em decorrência do mesmo, foram geradas informações úteis para serem utilizadas no gerenciamento ambiental integrado da região, mas que servirá não apenas para o delta, mas sim para regiões litorâneas em geral que são afligidas pelo mesmo problema.

Os impactos ambientais ocasionados pelos conflitos de uso da terra afetam a organização do espaço impedindo seu auto funcionamento, a conservação e recuperação. Pois, em virtude dos ecossistemas costeiros serem complexos e potencialmente produtivos, sendo 
explorados de sobremaneira e degradados, podem ocasionar efeitos negativos à biodiversidade e à manutenção das riquezas naturais tão importantes para toda a população da região deltaica. Portanto, há necessidade de maior fiscalização e implementação das políticas públicas já sugeridas, como pelo ZEE, por exemplo, a fim de trazer diretrizes para uma ocupação ordenada e em direção a uma sustentabilidade. De tal modo, se pode favorecer maior conservação do ambiente, assim como, nos casos observados, estimular a prática de um ecoturismo, tendo em vista o potencial para esta atividade, no entanto, assumida pela população local a partir da necessária consciência de sua territorialidade.

\section{REFERÊNCIAS}

ARAÚJO, J. L. L. Atlas escolar do Piauí: geo-histórico e cultural. João Pessoa: Grafset, 2006.

ARAÚJO, K. M. et al. Lagoa do Portinho em Parnaíba, Piauí, Brasil: avaliação da infraestrutura e atrativos turísticos . Revista Eletrônica em Gestão, Educação e Tecnologia Ambiental, v. 18 n. 2, p.769-776, 2014.

BRASIL. Lei no 9.985, de 18 de julho de 2000. Diário Oficial da União, 19 jul. 2000.

BRASIL. Ministério do Meio Ambiente. Zoneamento ecológico-econômico do Baixo Rio Parnaíba: fase de diagnóstico (sumário final). Brasília: MMA, 2008a.

BRASIL. Ministério do Turismo. Ecoturismo: orientações básicas. Brasília: Ministério do Turismo, 2008b.

SILVA, M. F. L. S. O ecoturismo no Delta do Parnaíba-PI e entorno: turismo e sustentabilidade. 2004. 93 f. Trabalho de Conclusão de Curso (Especialização) - Universidade de Brasília - UNB, Brasília, 2004.

SILVA, E. V; SOUZA, M. M. A. Principais formas de uso e ocupação do solo dos manguezais no estado do Ceará. Universidade Regional do Cariri - URCA. Revista Caderno de Cultura e Ciência, v.01, n.01, 2006.

SOUSA, R. S. Etnobotânica e Etnozoologia de comunidades pesqueiras da Área de Proteção Ambiental (APA) do Delta do Parnaiba. Dissertação (Mestrado em Desenvolvimento e Meio Ambiente) - Universidade Federal do Piaú, Teresina, 2010. 


\title{
VI
}

\section{GESTÃO AMBIENTAL EM MEIOS DE HOSPEDAGENS NO MUNICÍPIO DE TAMANDARÉ - PERNAMBUCO}

\author{
Áurea Nascimento de Siqueira Mesquita ${ }^{22}$ \\ Wagner José de Aguiar ${ }^{23}$ \\ Vanice Santiago Fragoso Selva ${ }^{24}$
}

\section{INTRODUÇÃO}

O turismo, importante atividade econômica do no Brasil vem se tornando destaque no âmbito da economia contribuindo para a geração de renda e de emprego, além da ampliação dos fluxos do turismo nas diferentes regiões do Brasil. De acordo com Castelli (2003), a expansão do turismo favoreceu o empreendedorismo dos meios de hospedagens sendo estes, uma das principais formas espaciais para a formatação de lugares e destinos turísticos, representando um setor primordial para o desenvolvimento socioeconômico de destinos ou áreas de interesses turísticos.

A área litorânea brasileira, especialmente da Região do Nordeste, apresenta um vasto crescimento econômico direcionado ao turismo com a formação de espaços voltados receberem turistas, formação de resorts, agregando atividades e utilizando elementos culturais e naturais existentes, principalmente as praias de águas tépidas.

Devido ao clima tropical e suas belezas naturais que atraem turistas de todas as regiões do mundo, o Nordeste brasileiro recebeu investimentos do poder público por meio do Programa de Desenvolvimento do Turismo do Nordeste-PRODETUR criado para promover o turismo na década de 1990. Esses investimentos possibilitou a instalação de infraestrutura

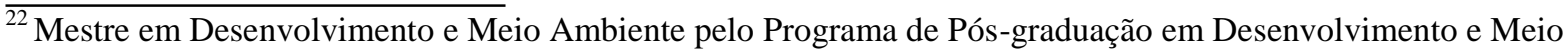
Ambiente (PRODEMA) da Universidade Federal de Pernambuco (UFPE). E-mail: aurea.ans@ gmail.com.

${ }^{23}$ Doutorando no Programa de Pós-graduação em Desenvolvimento e Meio Ambiente (PRODEMA) da Universidade Federal de Pernambuco (UFPE).

${ }^{24}$ Professora Adjunta do Departamento de Geografia da Universidade Federal de Pernambuco.
} 
básica para o turismo litorâneo no Estado de Pernambuco, assim como nos demais estados do Nordeste brasileiro com a construção de rodovias, ampliação de aeroportos, financiamento para meios de hospedagens e, estimulou o segmento hoteleiro, o que contribuiu para aumentar fluxo de turistas para a região Nordeste.

Os meios de hospedagens, segundo o Artigo 23 da Lei no11. 771/2008 que trata da Política Nacional de Turismo são compreendidos:

Por empreendimentos ou estabelecimentos que independentemente de sua
forma de constituição, destinados a prestar serviços de alojamento
temporário, ofertados em unidades de frequência individual e de uso
exclusivo do hóspede, bem como outros serviços necessários aos usuários,
denominado de serviços de hospedagem, mediante adoção de instrumento
contratual, tácito ou expresso, e cobrança de diária (BRASIL, 2008).

Como destaca a lei, os meios de hospedagens, contribuem para a prestação de serviços como uma das atividades que compõem o sistema turístico, assim como, para outras atividades econômicas como o comércio e para a elevação da renda da população, favorecendo a dinâmica do turismo nas regiões e lugares onde se instalam. Diante do processo de expansão da atividade turística com a instalação de empreendimentos hoteleiros utilizandose de ambientes naturais, impactos e problemas ambientais de naturezas diversas vêm tornando-se cada vez mais visíveis (GONÇALVES, 2004).

Como medida para minimizar impactos e problemas ambientais, mecanismos de gestão têm sido propostos no sentido de orientar o segmento hoteleiro para uma postura ambientalmente responsável a partir do Sistema Ambiental da Associação Brasileira da Indústria Hoteleira $(\mathrm{ABIH})$, do mecanismo de Produção Mais Limpa $(\mathrm{P}+\mathrm{L})$, do Sistema Ambiental Autônomo e a ISO 14000 (GONÇALVES, 2004).

Nesse contexto, levantam-se as seguintes questões: quais os entraves e as oportunidades presentes na viabilização da gestão ambiental em meios de hospedagem? Elas variam conforme o porte do empreendimento e a complexidade dos ambientes onde se encontram inseridos? Quais as práticas sustentáveis aplicadas aos meios de hospedagens?

Em meio a essas indagações, o presente artigo faz uma análise dos entraves e das oportunidades para a viabilidade da gestão ambiental em meios de hospedagens localizados no município de Tamandaré, situado no Litoral Sul do Estado de Pernambuco, para onde foram destinados recursos para a o projeto turístico do governo federal "Costa dos Corais".

Tamandaré é um município criado em 1995, desmembrado do seu vizinho, município de Rio Formoso que antes de se emancipar se destacava com um turismo de segunda residência. $\mathrm{O}$ crescimento do turismo em Tamandaré contribuiu para as instalações de meios 
de hospedagens, inicialmente nos anos de 2000, de pequeno a médio porte, nas praias de Tamandaré, Campas e Carneiros, onde se apresenta a maior concentração das atividades turísticas (GOMES, 2013) e, nesta última praia a partir de 2010, com empreendimentos de grande porte.

Em 1997, a porção Leste de Tamandaré, juntamente com os municípios de Serinhaém, Rio Formoso e Barreiros passam a integrar a então criada Área de Proteção Ambiental de Guadalupe pelo governo do Estado de Pernambuco como medida para ordenar o turismo com a criação do projeto Centro Turístico de Guadalupe abrangendo as praias de Tamandaré, Campas e Carneiros. No mesmo ano, a área marinha do município passou a fazer parte da Área de Proteção Ambiental Costa dos Corais criada pelo governo federal. Essas áreas de proteção ambiental foram criadas com o objetivo de manter a integridade do habitat, incentivar manifestações culturais contribuindo para o resgate da diversidade cultural regional e ordenar o turismo ecológico, científico e cultural, e demais atividades econômicas compatíveis com a conservação ambiental.

Devido ao município e as práticas turísticas estarem inseridas nas Áreas de Proteção Ambiental admite-se a necessidade dessas práticas estarem em consonância com os objetivos das referidas áreas. Desse modo a implantação de sistemas de gestão nos meios de hospedagens em áreas protegidas deve ser considerada pela gestão pública, de modo que as atividades turísticas estejam de acordo com os princípios da sustentabilidade. (GONÇALVES, 2004).

Portanto, é importante compreender o que representa entraves e oportunidades para a implantação da gestão ambiental nos meios de hospedagem e suas articulações, buscando analisar as práticas sustentáveis no município de Tamandaré e os benefícios em relação à minimização dos impactos ambientais no município.

\section{METODOLOGIA}

A pesquisa de caráter descritiva buscou trazer informações com base em entrevistas em meios de hospedagens sobre o que representa entraves e oportunidades para a aplicação de medidas práticas de gestão ambiental. Para atender o objetivo, foram definidas cinco etapas (Figura 1): 
Figura 1 - Etapas da Pesquisa.

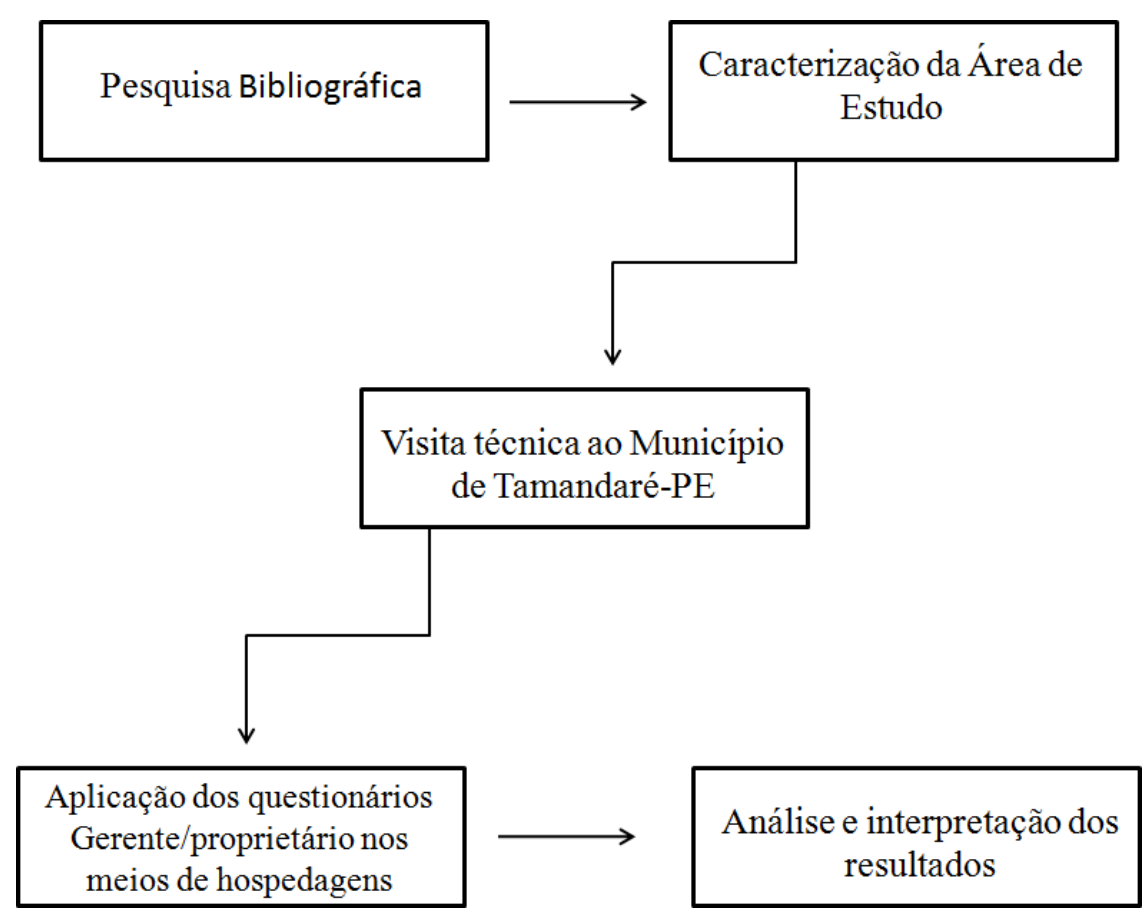

Fonte: Pesquisa direta (2017-2018).

$\mathrm{Na}$ primeira etapa buscou-se realizar uma pesquisa bibliográfica para o aprofundamento do tema da gestão ambiental, da classificação de empreendimentos hoteleiros e do turismo.

Com base na pesquisa bibliográfica, partiu-se para fazer a caraterização da área de estudo quanto aos aspectos geográficos, econômicos e sociais e as práticas turísticas locais. Seguindo-se a essa etapa foi realizada uma visita exploratória no município para complementação da caracterização da área e buscar informações sobre os tipos meios de hospedagens assim como o número existente, quantos são formais, quantos informais. Nessa visita, a Secretaria de Turismo do Município forneceu informações sobre o cadastro de 37 meios de hospedagens - hotéis, pousadas, chalés - de diferentes portes.

Tomando como referência os 37 meios de hospedagens existentes e considerando o que a estabelecem os documentos que definem os itens a serem considerados num sistema de gestão, foi elaborado um questionário para ser aplicados aos proprietários ou gerentes dos destes meios de hospedagem para buscar informações sobre a prática de atividades consideradas sustentáveis e o que representam oportunidades e entraves para a gestão 
ambiental. Dos 37 meios de hospedagem cadastrados foram aplicados 20 (vinte) questionários com perguntas abertas e fechadas, no período de setembro a novembro de 2017. Os 17 (dezessete) restantes que não responderam alegaram impossibilidade de atender no momento da pesquisa. Na quinta etapa, foi realizada a análise das informações obtidas a partir da aplicação dos questionários.

\subsection{Caracterização da área pesquisada}

De acordo com a Figura 2, o munícipio de Tamandaré, situado a $110 \mathrm{Km}$ da Capital do estado, Recife, se encontra localizado no Litoral Sul do Estado de Pernambuco, município litorâneo da Região Nordeste do Brasil. Apresenta uma extensão de aproximadamente $9 \mathrm{Km}$, e a sua costa é formada pela baía de Tamandaré, praia de Campas e pelas Praia dos Carneiros (FIRMINO, 2006). São nestas praias, as mais procuradas pelos turistas onde se concentram os meios de hospedagem.

Tamandaré apresenta $214.307 \mathrm{~km}^{2}$ de área da unidade territorial, com densidade demográfica de 96,66 hab/km (IBGE, 2010). Ainda de acordo com o IBGE (2010) a população local é representada por 20.715 habitantes.

Figura 2 - Mapa de localização do Município de Tamandaré-PE.

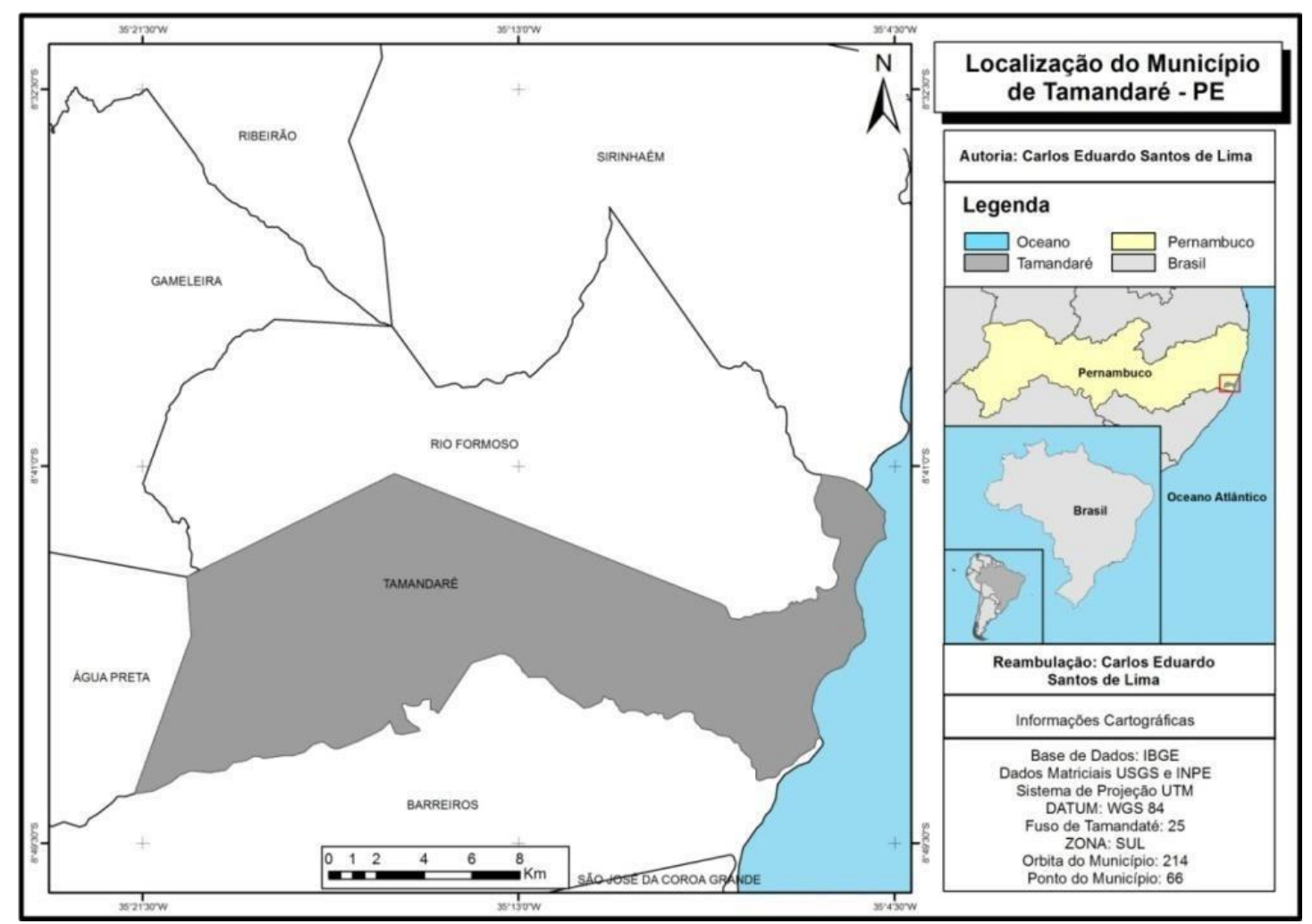

Fonte: IBGE (2010). Adaptado por Lima (2018). 
No contexto das regiões administrativas do estado de Pernambuco, o município de Tamandaré integra a Região de Desenvolvimento (RD), denominada como RD-10, localizada a Mesorregião da Zona da Mata Pernambucana, caracterizada desde o seu processo histórico até os dias atuais pela produção de monocultura da cana-de-açúcar (FIRMINO, 2006).

Como resultado das suas características naturais relevantes representadas pela ocorrência de Mata Atlântica, extensos manguezais, existência de bancos de recifes de corais e arenito e, do relevante patrimônio histórico representado por uma fortaleza construída do século XVII, toda porção Leste do município e o mar que banha, forneceram as condições para que fossem criadas quatro áreas protegidas de acordo com as classes estabelecidas no Sistema Nacional de Unidades de Conservação (SNUC): a Reserva Biológica (ReBio) de Saltinho e a Área de Proteção Ambiental (APA) Costa dos Corais no âmbito federal; a Área de Proteção Ambiental (APA) de Guadalupe no âmbito estadual e o Parque Natural Municipal Forte de Tamandaré, no âmbito municipal. São territórios instituídos legalmente pelo poder público em ambientes terrestres ou aquáticos, com atributos naturais e culturais relevantes do ponto de vista ecológico (BRASIL, 2011).

A criação destas quatro áreas protegidas aponta de um lado para a importância ecológica existente no município, o que fez atrair o turismo para principalmente a área de praia, e de outro a necessidade de práticas sustentáveis condizentes com as áreas de proteção.

Mesmo estando em área protegida sujeita a regramentos, a expansão do turismo tem contribuído para a artificialização das áreas naturais com a instalação de infraestrutura turística (SELVA, 2011) representada principalmente por meios de hospedagens.

\section{RESULTADOS}

De acordo com a pesquisa bibliográfica, observação local e informações obtidas na prefeitura municipal, Tamandaré apresenta uma estrutura de gestão ambiental, com vários órgãos públicos e organizações que contribuem para a governança local: a Secretária do Meio Ambiente, Conselho Municipal de Desenvolvimento do Meio Ambiente (COMDEMA) e Fundo Municipal de Meio Ambiente; a Secretaria de Turismo e do Conselho de Turismo (COMTUR); a presença do Centro de Pesquisa e Conservação da Biodiversidade Marinha do Nordeste (CEPENE), um dos centros especializados de pesquisa do Instituto Chico Mendes de Biodiversidade (ICMBIO) voltado para a pesquisa e a gestão dos recursos pesqueiros; a Agência Pernambucana de Recursos Hídricos (CPRH) e das organizações da sociedade civil 
Instituto Recifes Costeiros (IRCOS) e a Associação de Hotéis, Pousadas Restaurantes (AHPREST).

De acordo com o cadastro dos meios de hospedagens fornecido pela a Secretária de Turismo do município de Tamandaré, existem trinta e sete empreendimentos cadastrados no sistema de hospitalidade do Sistema de Cadastro de pessoas físicas e jurídicas que atuam no setor do turismo com o alvará da prefeitura para o funcionamento, o que possibilita o enquadramento da prefeitura das demandas para a gestão dos meios de hospedagens.

Apesar dos órgãos públicos e da estrutura existente para a gestão ambiental, o município evidencia entraves para a gestão ambiental nos meios de hospedagem como os reconhecidos Sistema Ambiental da Associação Brasileira da Indústria Hoteleira (ABIH), o mecanismo de Produção Mais Limpa (P+L), o Sistema Ambiental Autônomo e a ISO 14000.

Identificou-se que os meios de hospedagens no município desenvolvem alguma prática adequada para a sustentabilidade da atividade e para a conservação ambiental, porém não apresentam um padrão ou normas já reconhecidas e utilizadas a exemplo dos citados Sistema Ambiental da Associação Brasileira da Indústria Hoteleira (ABIH), mecanismo de Produção Mais Limpa (P+L), Sistema Ambiental Autônomo e a ISO 14000, embora existam interesses dos próprios proprietários ou gerentes de adequar o empreendimento em um dos citados mecanismos que venha contribuir para reduzir os impactos ambientais no município local, possibilitando melhor qualidade para o ambiente e para os hóspedes.

De acordo com os resultados dos questionários, os meios de hospedagens têm entre 01 e 30 anos de funcionamento, variando entre cinco e cinquenta unidades habitacionais oferecendo aos hospedes ar condicionado nos cômodos, acesso à internet áreas de convivência social, café da manhã e estacionamento para melhor comodidade.

Questionados sobre a localização do empreendimento em área de proteção ambiental (Gráfico 1), verificou-se que, $45 \%$ dos entrevistados sinalizaram que os empreendimentos não estavam inseridos em uma Área de Proteção Ambiental - APA, $35 \%$ tinha esse conhecimento em relação aos seus empreendimentos e $20 \%$ não souberam responder, deixando evidente nesta pesquisa que cerca de $55 \%$ dos responsáveis ou gerentes não tem essa informação fundamental para uma região que apresenta unidades de conservação ambiental que devem ser protegida e sujeitas a regramentos para a sua conservação. Esse é um aspecto importante a ser considerado não só por empreendedores hoteleiros, mas principalmente por gestores, pois, segundo Vasconcelos; Coelho; Selva (2016, p. 72), “O que se observa no âmbito do turismo é 
um apelo ao "contato com a natureza" e a natureza intacta e protegida torna-se um argumento comercial importante para o uso das áreas protegidas".

Gráfico 1 - Conhecimento sobre a Gestão Ambiental

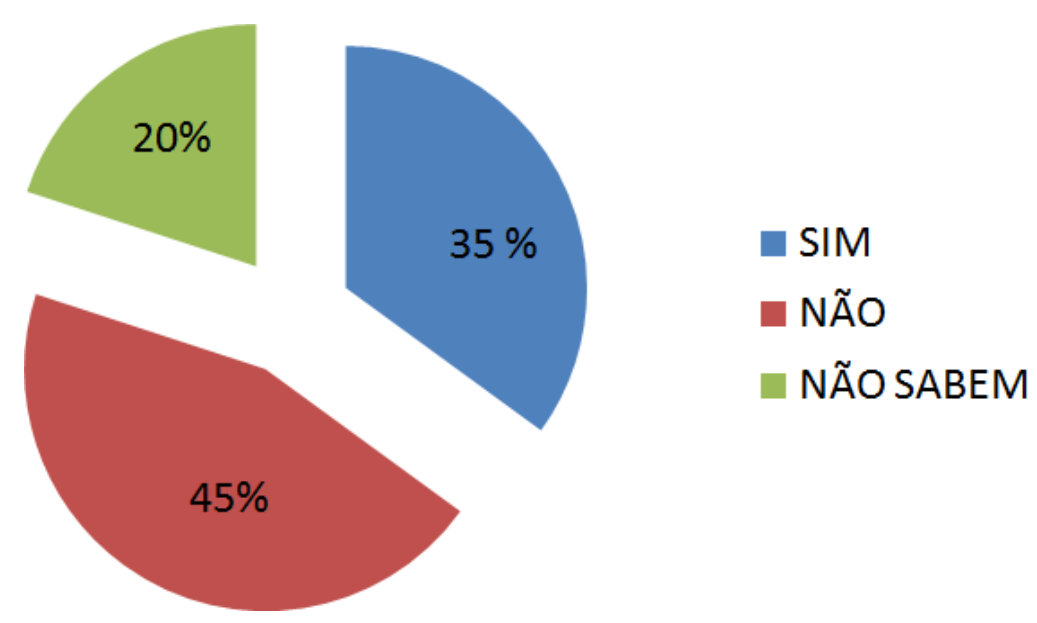

Fonte: Pesquisa direta, setembro de 2017.

Sobre as práticas sustentáveis desenvolvidas nos empreendimentos hoteleiros, a pesquisa apontou (Gráfico 2) que cerca de $60 \%$ dos empreendimentos não aplicam qualquer sistema de gestão ambiental, $10 \%$ se encontra em fase de implantação e $20 \%$ não têm esse tipo de informação, ou seja, não têm conhecimento sobre o tema.

Dos empreendimentos pesquisados apenas $10 \%$ afirmaram que desenvolviam práticas reconhecidas em sistema de gestão ambiental. Ressalta-se que estes empreendimentos que afirmaram desenvolver práticas reconhecidas de sistema de gestão ambiental, são empreendimentos com 01 a 08 anos de funcionamento, enquanto as mais antigas (entre 09 a 30 anos de funcionamento), não realiza nenhuma prática. 
Gráfico 2 - Práticas condizentes com Sistema de Gestão Ambiental - SGA.

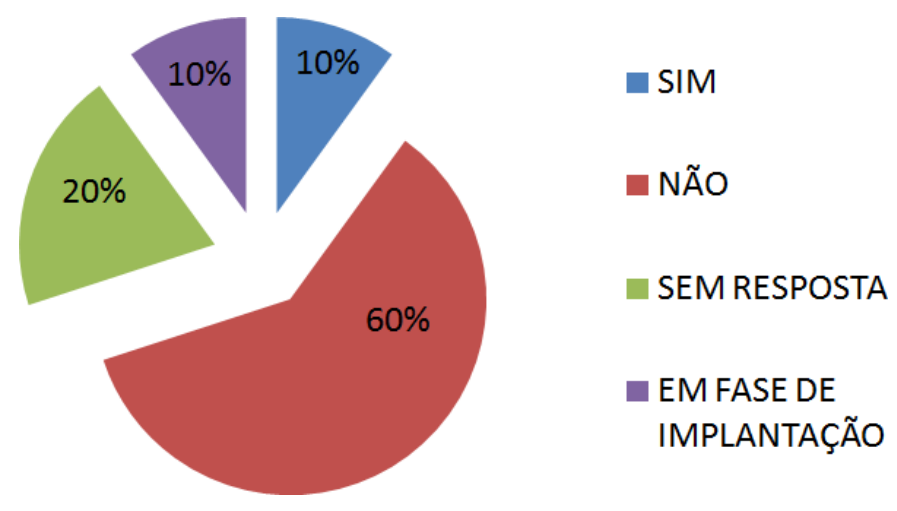

Fonte: Pesquisa direta, outubro de 2017.

No Gráfico 3, é possível observar a relação entre os empreendimentos e os gestores das APA's, que fazem a gestão ambiental das áreas e fiscalizam o que estabelecem as normas para os usos dos territórios através dos planos de manejo das APAs. Verifica-se que $45 \%$ dos proprietários/gerentes dos meios de hospedagem afirmam ter uma boa relação com a gestão das áreas protegidas e participam das reuniões voltadas as questões ambientais da área. Porém, 10\% alegaram que apresentam dificuldades em relação aos gestores, por não apresentarem práticas adequadas e interesses diretos voltados para o empreendimento hoteleiro. Um número representativo de $30 \%$ afirmou não apresentar nenhuma relação direta com os gestores e $15 \%$ não tem apresentaram nenhuma informação sobre esse tipo de relação.

Gráfico 3 - Relação entre empreendimentos hoteleiros e a gestão das áreas protegidas

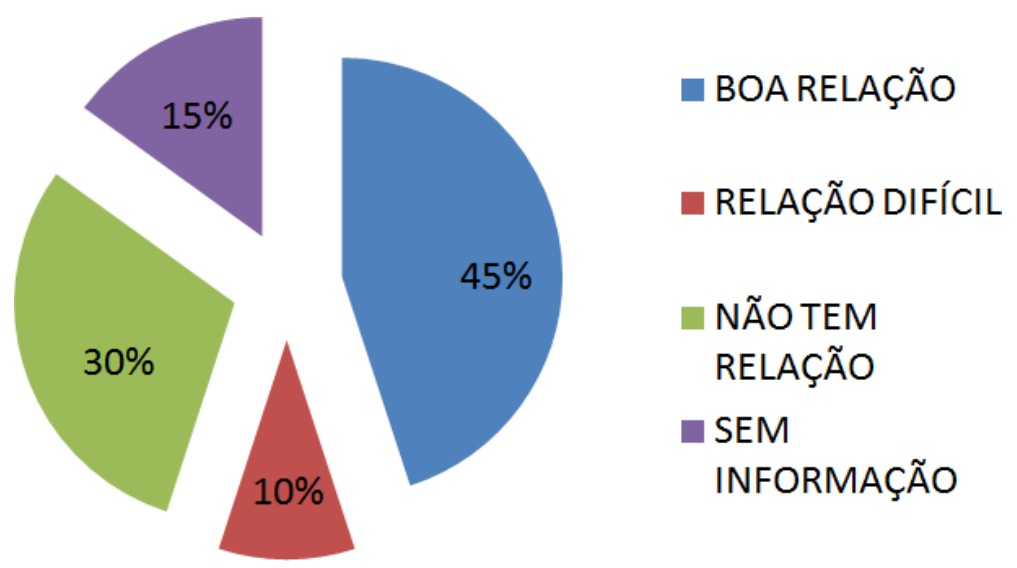

Fonte: Pesquisa direta, outubro de 2017. 
Todos os empreendimentos hoteleiros, independente do porte, inquiridos adotam algum tipo de prática voltada para a redução do consumo de energia como a utilização de chave-cartão, sensores de presença, lâmpadas de consumo reduzido, arquitetura do estabelecimento propício para ventilação natural e aproveitamento da iluminação solar, como também o incentivo aos hóspedes para a economia de água e energia. Outras práticas apontadas foram voltadas para a responsabilidade social, precisamente, contratando mão de obra do próprio munícipio além de sensibilizar os hóspedes sobre as ações socioambientais através de mural informativos ou panfletos, de modo a contribuir para conservação da cultura local.

A partir das informações apontadas nos gráficos, destaca-se a necessidade e importância da municipalidade estar articulada num sistema de governança ambiental para apoiar e estimular os proprietários de meios de hospedagem na adoção de práticas sustentáveis em seus empreendimentos de modo a minimizar os problemas e conflitos ambientais gerados na dinâmica do turismo.

\section{CONSIDERAÇÕES FINAIS}

O desenvolvimento do município de Tamandaré, por meios das atividades turísticas, tendo como base os recursos naturais como matéria-prima o que possibilitou a instalação e ampliação dos meios de hospedagens nos últimos 30 anos.

A existência de órgão públicos e organizações civis no município que discutem os problemas ambientais e o turismo representam uma oportunidade para a gestão ambiental dos meios de hospedagem na medida em que estes através de associação participam do Conselho Municipal de Meio Ambiente (Condema), principal fórum de discussão para pensar o ordenamento do turismo e os problemas ambientais.

Em Tamandaré, a aplicação de sistema de gestão ambiental em meios de hospedagens é preambular, o qual precisa de maior incentivo por parte da municipalidade e articulado com as orientações do plano de manejo das áreas protegidas para incentivar programas voltados a sustentabilidade hoteleira e a conservação ambiental.

Os meios de hospedagens de Tamandaré têm um papel fundamental na expansão e sustentabilidade da atividade turística local cujas práticas de gestão devem ser comprometidas com as atividades voltadas para práticas sustentáveis, desde a construção do empreendimento 
até o momento de funcionamento, cumprindo a legislação ambiental e minimizando o uso de água, energia, materiais, reduzindo os resíduos sólidos e os reaproveitando.

Diante tais informações, o município de Tamandaré tem como desafio a orientação para que os meios de hospedagem se enquadrem de acordo com o que orientam os planos de manejo das áreas protegidas encorajando os proprietários a realizarem medidas alternativas sustentáveis de modo a contribuir para o desenvolvimento local e do turismo.

A pesquisa permitiu identificar possíveis alternativas que podem ser implantadas no setor hoteleiro que venham por meio das parcerias dos órgãos gestores contribuírem para a gestão ambiental, reduzindo os impactos ambientais na área de proteção e favorecendo para o desenvolvimento econômico, cultural e social do município.

\section{REFERÊNCIAS}

BRASIL. Ministério do Meio Ambiente. SNUC - Sistema Nacional de Unidades de Conservação da Natureza: Lei $n^{\circ} 9.985$, de 18 de julho de 2000; Decreto $n^{\circ} 4.340$, de 22 de agosto de 2002; Decreto n ${ }^{\circ} 5.746$, de 5 de abril de 2006. Plano Estratégico Nacional de Áreas Protegidas: Decreto n ${ }^{\circ}$ 5.758, de 13 de abril de 2006 / Ministério do Meio Ambiente. Brasília: MMA/SBF, 2011.

BRASIL. Lei no11. 771/2008 que trata da Política Nacional de Turismo.

CASTELli, G. Administração Hoteleira. 9. ed. Caxias do Sul: EDUCS, 2003.

FIRMINO, F.S. Dinâmica do Turismo na Zona Costeira Nordestina. 2006 - Dissertação de Mestrado do Programa de Desenvolvimento e Meio Ambiente- PRODEMA/UFPE. Recife, 2006.

GIL, A. C. Como elaborar projetos de pesquisa. 4. ed. São Paulo: Atlas, 2007.

GOMES, C.C. Turismo e desenvolvimento local: desafios e possibilidades para o município de Tamandaré-PE. Dissertação/ Prodema - UFPE. 2014. Disponível em:< http://repositorio.ufpe.br/handle/123456789/12145> Acesso em: 30. Out 2017.

GONÇALVES, L. C. Gestão ambiental em meios de hospedagem. São Paulo: Aleph, 2004.

Instituto Brasileiro de Geografia e Estatística - IBGE. Cidades, Tamandaré - Pernambuco. Disponível em: <https://cidades.ibge.gov.br/xtras/perfil.php?codmun=261485> Acesso em: 05. Out.2017.

SELVA, V. S. F. Área de Proteção Ambiental de Guadalupe: de ambiente natural a Espaço do turismo. Revista Nordestina de Ecoturismo, Aquidabã, v.5, n.1, Nov, dez 2011. 
TAMANDARÉ. Relação dos meios de hospedagens cadastrados no município.

Tamandaré, 2017.

VASCONCELOS, L.; COELHO, M.; SELVA, V. Patrimônio natural em áreas de protegidas: Consensos e dissensos no uso turístico. In: Queiroz, O. T. M.; PORTUGUEZ, A. P.;

SEABRA, G. de F.; MORAES, C. S. B. de. A natureza e o patrimônio na produção do lugar turístico. Ituiutaba: Barlavento, 2016. 


\title{
A CIDADANIA AMBIENTAL POR MEIO DE POLÍTICAS PÚBLICAS NO BRASIL
}

\author{
Flávio Marcelo Rodrigues Bruno ${ }^{25}$ \\ Raimundo Giovanni França Matos ${ }^{26}$ \\ Jonhanny Mariel Leal Fraga ${ }^{27}$ \\ Rubio José Ferreira ${ }^{28}$
}

\section{INTRODUÇÃO}

O presente capítulo se propõe a avaliar o exercício da cidadania socioambiental considerando a participação pública, com base no conhecimento do dever compartilhado de tutela ambiental sob o viés do acesso à justiça, por meio dos instrumentos processuais previstos na Constituição da República Federativa do Brasil.

O tema é de atual relevância no cenário jurídico-ambiental, o que faz referência a diversas provocações, tanto nas implicações do direito socioambiental quanto nas análises das garantias constitucionais para a efetivação do dever compartilhado, em especial no estudo do acesso à justiça a partir dos instrumentos processuais de efetividade das tutelas ambientais sob a ótica da participação pública.

Algumas indagações são respondidas e outras necessitam de respostas para uma efetivação de uma cidadania socioambiental. Entre elas estão: qual o paradigma contemporâneo da relação entre o homem e a natureza a partir do socioambientalismo? Quais os fundamentos da perspectiva de uma cidadania socioambiental a partir de um dever

\footnotetext{
${ }^{25}$ Professor Doutor da Universidade Federal do Oeste da Bahia - UFOB, e-mail: flavio.bruno@msn.com.

${ }^{26}$ Doutor em Direito Político e Econômico pela Universidade Presbiteriana Mackenzie - SP e coordenador de Curso de Direito da Universidade Tiradentes em Sergipe, no campus Itabaiana/Se, e-mail: rg.adv@ hotmail.com. ${ }^{27}$ Graduada em Direito pela Universidade Tiradentes (UNIT) no Estado de Sergipe.

${ }^{28}$ Doutor em Geografia. Professor adjunto na Universidade Federal do Oeste da Bahia (UFOB) - Centro de Humanidades. Bolsista de Extensão pelo CNPq. Líder do Grupo de Pesquisa Dinâmicas Espaciais e Desenvolvimento Territorial (GRUDED), na UFOB, e-mail: rubio.ferreira@pq.cnpq.br.
} 
compartilhado de proteção do meio ambiente? É possível, no caso do Brasil, ampliar-se o acesso à justiça a partir da perspectiva socioambiental considerando os instrumentos processuais para o exercício da tutela ambiental, previstos e garantidos na Constituição Federal?

Considerando-se que a cultura no Brasil, via de regra, é a de que proteção do meio ambiente é problema do Estado, no mais das vezes o cidadão fica no aguardo de que o ente público tome sempre a iniciativa. Não há essencialmente uma sensibilização da relação entre homem e natureza que poderia desenvolver uma maior proteção jurídica ambiental. Ainda que tente se materializar o caput do art. 225 da Constituição Federal, no qual se garante tanto ao Poder Público quanto à coletividade o dever compartilhado de proteção ao meio ambiente, o cidadão, parte dessa coletividade, vê na dificuldade do acesso à justiça, um problema para a efetividade da tutela jurídica ambiental.

Procura-se nesse capítulo demonstrar a necessidade de uma emergência de cidadania socioambiental considerando uma análise das garantias constitucionais, especialmente em relação ao estudo do acesso à justiça a partir dos instrumentos processuais de efetividade das tutelas ambientais, na tentativa de encontrar respostas às indagações anteriormente referidas.

\section{CAMINHOS DA CIDADANIA NO BRASIL}

O termo cidadania, historicamente, vincula-se ao exercício e à conquista de direitos, os quais passam por um longo caminho e por trajetórias, a exemplo dos direitos políticos, civis e sociais na história do desenvolvimento do Brasil, considerando-se o momento histórico, espaço geográfico, nível de desenvolvimento econômico e cultural particular de cada sociedade.

Na contemporaneidade, a questão ambiental é cada vez mais observada e inserida do que em outros momentos históricos, sendo ponto crucial sua discussão enquanto conquistas de direitos do cidadão, a exemplo da garantia constitucional a todos de um meio ambiente sadio e ecologicamente equilibrado para as presentes e futuras gerações, abrindo-se o debate para consideração de uma nova dimensão da cidadania.

Como dito anteriormente, tem-se que, no Brasil, a proteção ao meio ambiente é problema do Estado e, no mais das vezes fica-se no aguardo do ente público tomar sempre uma iniciativa, seja ela administrativa ou judicial para tal finalidade. Entretanto, o direito a um meio ambiente sadio para as gerações presentes e futuras é uma garantia constitucional, de 
responsabilidade compartilhada entre Estado e cidadão, especialmente prevista no art. 225 da CF/88.

Com efeito, verifica-se na observação de Bodin apud Smanio (2015), que no ano de 1576 com a Les Six Livres de la Republique, no momento de surgimento do Estado Moderno, o conceito ou ideia de cidadão dá seus primeiros passos a partir da relação entre soberano e seus súditos. Aquele deveria prezar pela proteção e justiça desses, os quais se encontravam numa situação de submeter o exercício de direitos à obediência do soberano. Logo, nem todos detinham essa condição, pois, à época, escravos, mulheres, crianças não se encaixavam nesse status (BODIN apud SMANIO, p. 1-5). Assim, a qualidade de cidadão nasce de uma percepção claramente excludente de uma condição atribuída a poucos, ou seja, cidadão é uma qualidade que foi sendo adquirida ao longo do tempo e por vezes, de formas distintas.

Em Marshall (1967), cidadania é um conjunto de direitos civis, políticos e sociais, nessa ordem e desenvolvida na Inglaterra do Sec. XVIII, quando cronologicamente houve a aquisição legal de direitos fundamentais à vida, liberdade, propriedade e igualdade, e, após, já no século XIX sobrevieram os direitos de participação no governo, ao se instituir o direito de votar e ser votado. Na sequência, o direito ao trabalho, educação e saúde despontam no século XX. Porém, conforme o mesmo autor, tal ordem de surgimento e afirmação desses direitos não segue uma teoria geral para a formação da cidadania em outros países.

No Brasil, os direitos do cidadão seguiram uma ordem diversa da apontada por Marshall. Como explica Carvalho (2007, p. 18) que, "à época da independência não havia cidadãos brasileiros, nem pátria brasileira”. Desta feita, num Brasil recém independente e de proporções territoriais continentais, predominava um Estado absolutista de população analfabeta, sociedade escravocrata e de economia monocultora e latifundiária. Antes disso, o brasileiro foi sendo construído sob as matrizes do índio que já habitava o território, o negro trazido da África e do europeu agressivo cujo único objetivo era o de gerar riquezas para suas pátrias (RIBEIRO, 2006, p. 26-27).

$\mathrm{Na}$ formação da cidadania brasileira, a força da escravidão aliada à grande propriedade em posse de pouquíssimos, foram fatores que contribuíram negativamente para delimitar as suas bases. Remetendo-se à época da Colônia, como não se verificavam direitos civis aos escravos, não há que se falar em cidadãos. Por outro lado, o sentido de cidadania também não poderia ser encontrado naqueles que eram considerados os senhores, uma vez que, apesar de serem livres, não detinham a compreensão de igualdade para todos perante a lei (CARVALHO, 2007, p. 21). 
Sendo assim, é possível deduzir que nessa fase histórica do Brasil, não há que se falar de cidadãos ante à ausência e percepção dos direitos civis, políticos e sociais, como argumenta Carvalho (CARVALHO, 2007, p. 24): "Os direitos civis beneficiavam a poucos, os direitos políticos a pouquíssimos, dos direitos sociais ainda não se falava, pois, a assistência social estava a cargo da Igreja e de particulares".

Historicamente, a noção de cidadão no Brasil é concreta a partir da Constituição de 1824, após a independência, despontando e regulando-se os direitos políticos sem muita compreensão daquilo que representavam, haja vista definir quem podia votar e ser votado, contudo sem alteração consistente do período colonial, apenas transformando em cidadãos aqueles brasileiros analfabetos que não tinham a menor compreensão da prática do exercício do voto num governo representativo. À época, tudo funcionou para, concedendo-se direitos, permanecer o poder político local.

Posteriormente se somaram os direitos civis notadamente o da propriedade, mas essa caracterizada pelo latifúndio, num país cuja herança e tradição fora a de estender o sistema de escravidão. Essa carregou sempre um valor muito forte na sociedade brasileira. Carvalho (CARVALHO, 2007 p. 53) aponta as consequências da escravidão como algo que determina a formação do cidadão no Brasil, uma vez que afetou tanto o escravo quanto o senhor, ainda no momento pó abolição da escravatura, mesmo porque, não houve desenvolvimento da consciência de direitos civis porque uma classe sempre estava abaixo da lei e a outra acima. Ou seja, $[\ldots]$ essa igualdade era afirmada nas leis, mas negada na prática [...]. Comenta o autor inclusive que:

\begin{abstract}
Mesmo os escravos, embora lutassem pela própria liberdade, embora repudiassem sua escravidão, uma vez libertos admitiam escravizar os outros. Que os senhores achassem normal ou necessária a escravidão, pode entender-se. Que libertos o fizessem, é matéria para reflexão. Tudo indica que os valores da liberdade individual, base dos direitos civis, tão caros à modernidade europeia e aos fundadores da América do Norte, não tinham grande peso no Brasil (CARVALHO, 2007, p. 49).
\end{abstract}

Quando do Estado Novo, os direitos sociais se apresentam para o cidadão, no entanto de uma forma ainda excludente, destinada a alguns grupos sociais. Poucos foram os movimentos políticos destinados à luta por direitos sociais, a exemplo do movimento abolicionista. Com isso, a cidadania no Brasil tem a característica de haver sido ordenada diferentemente do modelo francês ou inglês, e ainda de formação tardia, mas rumo a constantes superações diante da dinâmica e complexidade das transformações sociais.

Cidadania implica em qualquer lugar do mundo em participação efetiva da vida política. No Brasil, diante da formação histórica do cidadão às avessas de um modelo padrão, 
não se habituou exercer instrumentos de participação num governo de representação, mesmo porque não houve sequer a consciência daqueles direitos que foram sendo oportunamente concedidos.

A condição de cidadão e do exercício da cidadania vem ganhando novos contornos na modernidade, principalmente naquilo que se diz respeito à questão ambiental, provocando de igual forma novas discussões sobre a identidade de uma cidadania ambiental.

Ainda assim, no modelo brasileiro de construção da cidadania, nota-se a sua incompletude e um rumo necessário e certo para o desenvolvimento, ademais, conforme Guerra (2012, p. 63), a cidadania se apresenta em "múltiplas facetas relacionadas à liberdade e à igualdade e se pode dizer que ainda é uma tarefa inacabada, posto que sua construção continua em andamento, seja no âmbito local ou internacional".

Com efeito, a cada conquista da humanidade realizada por meio do indivíduo ou de grupos sociais, tem-se um acréscimo na condição do cidadão. Tais conquistas ocorrem no seu tempo e no lugar que lhe convier, assim é o exemplo da formação da cidadania em diferentes partes do mundo. $\mathrm{O}$ que se observa de forma comum é a necessidade e capacidade de se colocar diante das dominações do Estado ou de grupos privilegiados, como destacou Moura, aduzindo ainda que "cidadania não é uma atitude passiva, mas ação permanente, em favor da comunidade", bem como que se trata de "um conceito aberto, que não termina com mais uma conquista" (MOURA, 2013, p. 7, 9).

Nota-se que a inquietude dos movimentos sociais, bem como o surgimento de novos direitos, ambos atuam na formação constante da cidadania. É o que se percebe quanto ao tratamento da questão ambiental no ordenamento jurídico brasileiro, especificamente a partir da $\mathrm{CF} / 88$, quando de uma vez por todas, passa-se a verificar tanto no direito como no dever ao meio ambiente como sendo uma questão de exercício da cidadania.

\section{O DEVER COMPARTILHAdO DE PROTEÇÃO AO MEIO AMBIENTE: OBRIGAÇÃO CONSTITUCIONAL DO ESTADO E DO CIDADÃO}

Sobre a compreensão do meio ambiente como direito do cidadão e seu dever de proteção, a CF/88 marcou a saída do estágio da miserabilidade ecológica constitucional observado nas Constituições anteriores, conforme lição de Machado (2010) quando leciona que é a partir dela que se insere o tema meio ambiente em sua concepção unitária, conceituando-se como bem de uso comum do povo. 
A constitucionalização do meio ambiente verificado na $\mathrm{CF} / 88$ traz benefícios variados e de diversas ordens, o que pode ser bastante significativo para o relacionamento do homem com a natureza Benjamin (2010). O direito ao meio ambiente ecologicamente equilibrado é um direito de terceira geração, oriundo do desenvolvimento daqueles direitos individuais tidos como direitos humanos de primeira geração, mas que se concebem como transgeracionais porque se garantem àqueles indivíduos ainda não nascidos (BUCCI, 2006).

Por outro lado, o mesmo art. 225 da $\mathrm{CF} / 88$ estabelece também quem são seus protetores, ou seja, aqueles que têm a obrigação da sua defesa e preservação para as gerações presentes e futuras. São, então, os defensores do meio ambiente ecologicamente equilibrado: o poder público e a coletividade, a quem cabe, então, os deveres socioambientais, o que nada mais são do que o exercício da própria cidadania. Evidente que num governo democrático cuja característica primordial é a representatividade, a participação popular indica o nível de plenitude do exercício da cidadania.

No entanto, as democracias participativas carecem da intervenção popular de forma consciente, não necessariamente quanto ao voto, mas, sobretudo quanto aos meios disponibilizados constitucionalmente em qualquer esfera do poder. A fase de confiar o voto ou a representação para quem de direito foi paulatinamente sendo superada por uma ideia de participação mais efetiva e direta. Dessa feita, foram surgindo formas de participação da gestão pública, a exemplo do orçamento participativo, que aproximam o cidadão da política e por fim dá-se visibilidade à eficácia desses instrumentos.

Quanto ao tema meio ambiente, sobre sua defesa e proteção e das possiblidades de participação da sociedade, fica cada vez mais evidente que é um tipo de problemática que, ao longo do tempo, exigirá de forma mais frequente a participação consciente do cidadão. Conforme Mirra (2010, p. 22), estar-se-á diante de uma realidade inafastável, mesmo porque:

[...] participação popular e defesa do meio ambiente são temas indissociáveis. Daí a imperiosidade da abertura de canais institucionais que viabilizem a participação do público na preservação ambiental, seja na esfera legislativa, seja na esfera administrativa, seja na esfera judicial. [...]

Com efeito, salienta-se a questão da participação popular nas democracias e nos assuntos diretamente relacionados ao povo e a forma da sua representação, como fruto de uma evolução das próprias democracias liberal e social. Ocorre que, conforme salientado por Mirra (MIRRA 2010, p. 32), a participação popular se consagrou entre o século XIX e XX, na "prevalência dos mais bem-dotados economicamente" o que só contribuiu para as "desigualdades sociais crescentes e aviltantes à dignidade humana", mesmo porque naquela época não se tratava ainda do sufrágio universal, o qual, na afirmação de Ramos apud Mirra 
(MIRRA 2010, p. 33), passa a ser considerado como o instrumento essencial para que as necessidades de bem-estar da sociedade em razão da maior percepção de uma igualdade para todos.

Ocorre, porém, que apesar da consolidação do voto universal e a igualdade entre os indivíduos, foi gerando ao longo do tempo numa dificuldade entre os partidos políticos em cada vez mais captar e atender as demandas sociais, o que se configurou numa dificuldade de expressar, de acordo com Mirra (2010, p. 25), a "genuína vontade popular" resultando no ponto principal da crise de legitimidade da democracia social, para a qual tem sido proposta a democracia participativa, baseada na intensa participação popular e não mais apenas através da representação política-eleitoral.

Participar como paradigma numa democracia moderna na observação de Mirra (2010, é fazer com que o indivíduo, enquanto cidadão, seja desenvolvido para uma maior conscientização social contribuindo para a formação de uma comunidade mais ativa politicamente. Ao longo do tempo, vários instrumentos de participação do povo foram sendo incorporados nas democracias o que resulta numa ampliação e frequência dos movimentos populares que buscam reivindicar o atendimento daquilo que seriam carências mais básicas.

Com a definição e sedimentação de uma democracia participativa na qual cada vez mais o povo, ou o cidadão deverá estar presente nas tomadas de decisões políticas e definições daquilo que mais lhe interessa e é necessário, verifica-se conforme lição de Morin (2013, p. 82), que tal participação há de se conceber em escalas locais, favorecendo os despertares dos cidadãos para uma regeneração do pensamento político, o que necessariamente contribuiria para a compreensão dos mais importantes problemas. Prossegue o autor, quanto à necessidade do favorecimento desse despertar que:

Seria igualmente útil multiplicar as universidades populares, que ofereceriam aos cidadãos uma iniciação ao pensamento complexo, permitindo agrupar os problemas fundamentais e globais e disponibilizar, de um lado, um conhecimento não mutilado, e, de outro, uma iniciação às ciências históricas, políticas, sociológicas, econômicas, ecológicas (MORIN, 2013, p. 82).

Essa visão ou entendimento, coaduna com uma necessária mudança de paradigma sobre a percepção dos principais problemas da modernidade e que estes estão interligados e não poderiam ser entendidos isoladamente, dentre os quais a questão ambiental. Contudo, para Capra (2006), tal mudança necessariamente deve passar por aqueles que seriam os nossos principais líderes políticos, administradores e professores das universidades. 
Com efeito, numa democracia participativa mister a presença de formadores de opiniões que naturalmente estão nas classes políticas, administrativas e instituições de ensino, para assim ganhar corpo e atingir proporções capazes de conceber naturalmente os principais e atuais problemas sociais, a exemplo da questão ambiental, sendo então cada vez mais necessário o implemento de políticas públicas para sedimento e concretização dessa participação.

\section{A CIDADANIA AMBIENTAL E AS POLÍTICAS PÚBLICAS}

Na defesa e proteção do meio ambiente, necessário se faz a produção de normas que viabilizem a colaboração e a participação da sociedade nas decisões, conforme explica Derani (2008). Ademais, conclamando-se o princípio da participação ${ }^{29}$, apesar dos avanços nas legislações do mundo ao tratar a matéria da participação cívica na defesa e proteção ambiental, ainda não é o suficiente. Para Machado, essa participação cívica na conservação do meio ambiente não é um processo político já terminado (MACHADO, 2010). No Brasil, o direito ao meio ambiente ecologicamente equilibrado é um fim garantido constitucionalmente, mas que possui um caminho aberto a ser perseguido e que, no entanto, este caminho é definido pela instituição de políticas e normas ordinárias visando especificar como e em que medida este fim pode e deve ser alcançado (DERANI, 2008, p. 252).

Séguin (2003, p. 303), com referência à participação popular na defesa ambiental, diz que o objeto do próprio princípio da participação é o de impedir "a formação de um exército de silenciosos". E provoca reflexões ao realizar indagações tais como: "Mas, serão realmente silenciosos? Ou serão mudos, por não terem aprendido a exercitar sua cidadania exigindo direitos fundamentais e civis? Exsurge outra questão: esse exército conhece seus direitos para poder exercê-los?".

Com efeito, a autora conduz para a questão da obrigação de participar conscientemente. Sua reflexão transita por um caminho que para participar da proteção ambiental o cidadão precisa ser bem informado da necessidade da preservação ambiental e de estar convicto que em sendo necessário deverá interferir consciente de que estará praticando

\footnotetext{
${ }^{29}$ Explica Antunes que os movimentos reivindicatórios dos cidadãos funcionam como uma das origens do Direito Ambiental e, em razão disso, a participação do cidadão consiste numa das bases mais caras e consistentes dentro de uma democracia, prescindindo especialmente do direito à informação e à participação (ANTUNES, Paulo de Bessa. Direito ambiental. 17. ed. São Paulo: Atlas, 2015, p. 26-27).
} 
uma atividade solidária, a qual em verdade é a base do princípio da participação. Sobre este, aduz que:

\begin{abstract}
O princípio da participação traduz-se assim no envolvimento de todos os segmentos da sociedade nas questões ambientais como forma do pleno exercício da cidadania. Manifesta-se de diversas formas que podem ser acionadas simultaneamente pela sociedade. A participação auxilia na conscientização de que a comunidade também é responsável pela preservação ambiental ao atribuir-lhe responsabilidades. Torna-se também um fiscal das atividades poluidoras. Através da participação a coletividade deixa de ser um espectador e assume seu papel de ator social e de parceiro na preservação ambiental (SÉGUIN, 2003, p. 314).
\end{abstract}

Sendo assim, Bucci (2006) define política pública como sendo o programa de ação governamental que resulta de um processo ou conjunto de processos juridicamente regulados - processo eleitoral, processo de planejamento, processo de governo, processo orçamentário, processo legislativo, processo administrativo, processo judicial - visando coordenar os meios à disposição do Estado e as atividades privadas, para a realização de objetivos socialmente relevantes e politicamente determinados. Todavia, quando se trata de política pública, estarse-á tratando da dimensão do termo política relacionado com a orientação para decisão e ação, na lição de Secchi (2012).

Com efeito, a participação do cidadão na defesa e preservação do meio ambiente ecologicamente equilibrado se faz necessária e perceptível a partir do momento que o mesmo compreende na norma que não se trata somente de dever, mas que é um direito também, e, esse momento é o da efetivação dessa norma, verificando-se que a plena concretização desse direito ocorre na medida em que o cidadão, jurista ou não, trabalhe pela sua efetividade material e o Estado atue administrando, usando de seu poder de polícia, planejando e incentivando condutas, assim explica Derani (2008).

Antunes (2005) trata da participação cívica nos problemas ambientais destacando quanto ao direito de opinar sobre as políticas públicas, citando as formas a participação em audiências públicas por órgãos colegiados, como também a participação mediante mecanismos judiciais e administrativos de controle dos atos praticados pelo Executivo, a exemplo das ações populares, e ainda, a participação por iniciativas legislativas, a exemplo da Iniciativa Popular, Plebiscito e Referendo.

No entanto, a educação pode ser o instrumento essencial para essa participação do cidadão. Conforme Pamplona (2012, p. 116), a existência de um programa governamental não é suficiente, mas, a informação é essencial para o cidadão "fiscalizar a eficácia das decisões políticas tomadas" e ato contínuo que "o projeto apresente resultados efetivos aos olhos de uma população instruída”. Seguem adiante explicando que "cabe ao poder público garantir 
um nível essencial de educação para todos, de forma que as pessoas detenham conhecimento necessário para viabilizar sua participação".

No mesmo sentido, Seguin (2006, p. 317) esclarece que a participação do cidadão deverá ser precedida de políticas públicas que envolvam não só o Estado mas, Organizações Não-Governamentais ambientalistas, "fortalecendo o papel do cidadão não apenas como titular de direitos, mas como segmento social representativo de poder", e essa participação é característica de um Estado democrático de direito o qual deverá garantir os meios necessários para que o cidadão exerça o seu direito de intervir; ademais, o exercício da cidadania se dá também através da modalidade tida como participação, e segundo a autora,

\footnotetext{
Ela não acontece apenas quando o indivíduo exerce sua capacidade eleitoral, passiva ou ativa. Questionou-se quem tem o direito de participar. Hoje pode-se responder sem sombra de dúvidas todos, e que participar, mais que um direito, é um dever de todo cidadão. Omitir-se é compactuar com aquilo que se rejeita. Inadmissível é ficar calado vendo os recursos naturais serem destruídos. O maior pecado de um cidadão é a omissão (SÉGUIN, 2006, 319).
}

Com efeito, sem educação o indivíduo tem sua participação na construção de uma cidadania ambiental deficitária, o que poderia prejudicar o resultado de políticas públicas educacionais para a formação e informação do cidadão com o objetivo de melhor conscientizar para o exercício dos direitos socioambientais e defesa do meio ambiente.

Percebe-se que na história da democracia a participação do cidadão foi se tornando cada vez mais essencial. No entanto, para uma participação efetiva é necessário conhecer, mesmo em um dos modos de se expressar a vontade popular, qual seja o voto, que é fundamental o conhecimento, afim de que desse ato resulte o mais próximo possível o interesse do povo. Ao entender de Morin (2013), em tempo de crises e preocupações ambientais globais, vivemos uma outra crise que é a do conhecimento.

Ou seja, se não conhecemos ou mal percebemos e ainda subvalorizamos os problemas ambientais, estaremos sendo conduzidos a erros no autoconhecimento. Daí que argumenta sobre uma reforma do conhecimento para reformar o pensamento, o que só seria possível através da educação.

\section{AS QUESTÕES AMBIENTAIS NA CONTEMPORANEIDADE E A EMERGÊNCIA DA CIDADANIA AMBIENTAL}

Mirra (2010, p. 43) destaca o reconhecimento da participação cidadã tanto no âmbito internacional quanto no nacional, considerando indispensável a presença de um maior número 
possível de "atores sociais como fator preponderante para a preservação do meio ambiente nos diversos países e no mundo". Especificamente quanto ao Brasil, o autor argumentando sobre a ausência de um envolvimento inicial da sociedade civil na política ambiental, pondera que,

\begin{abstract}
[...] não há como negar a evolução operada na participação pública para a defesa do meio ambiente, em especial nos anos 1980, quando se conquistou a abertura de inúmeros canais para veiculação de reivindicações de cunho ambientalista e se verificou o crescimento do movimento portador de tais demandas, o qual conheceu o seu apogeu no início dos anos 1990, época da realização, no Rio de Janeiro, da Conferência das Nações Unidas sobre Meio Ambiente e Desenvolvimento [...] (MIRRA, 2010, p. 43).
\end{abstract}

Essa indispensabilidade da participação popular na questão da proteção ambiental, de acordo com Mirra (2010, p. 51), é uma orientação que vem se consagrando e se reafirmando nos principais fóruns internacionais de discussão os quais são promovidos pela Organização das Nações Unidas e com o aceite dos seus países membros, a exemplo do Brasil, ao firmarem compromisso de implementação dessa participação. No entanto, na observação de Silva (2000), há de se considerar que houve avanços institucionais no Brasil quanto à participação popular na defesa do meio ambiente, contudo essa implementação foi mais fruto de uma consequência da estratégia para atender aos critérios rigorosos das agências de financiamento internacionais, do que visando ceder às pressões populares.

Ocorre que, partindo da indispensável participação popular nas questões ambientais, Guerra e Guerra (2012) afirmam ser de igual forma imprescindível a consciência cidadã e a atenção à coisa pública para a consagração de um paradigma democrático pautado na participação popular orientada na compreensão do texto constitucional. Dessa forma, tem-se um ideal democrático como princípio característico do nosso Estado Constitucional que aponte para cidadãos "informados sobre os acontecimentos e capazes de optar entre as alternativas oferecidas pelas forças sociopolíticas e interessados em formas diretas e indiretas de participação" (GUERRA E GUERRA, 2012, p. 36).

Dessa forma, equilibrando-se os avanços institucionais no Brasil com a compreensão do texto constitucional aliado a uma legislação privilegiada sobre os assuntos ambientais resultaria na formação de um cidadão cada vez mais capaz de exercer a pressão específica que possa atender aos seus reclames identificados inclusive através das políticas públicas.

Guerra e Guerra (2012, p. 41) explicam que fomentar políticas públicas tem consonância com as especificidades regionais para atender e observar tanto as potencialidades e dificuldades que viabilizem determinadas ações com o objetivo de maior efetividade ao 
princípio da dignidade da pessoa humana. Destacam, nesse sentido, acerca das atividades econômicas que "não podem ultrapassar as possibilidades do ambiente, sob o risco de comprometer recursos obtidos", e que venham a favorecer a "utilização dos recursos de forma predatória, culminando com a eliminação do bem a ser explorado".

Com efeito Silva (2015) comenta o conceito de políticas públicas de Bucci, expondo que deve haver um componente prático e finalístico e que busque a concretização de determinados objetivos e metas, considerando um determinado espaço geográfico, referindose ao espaço nacional, e a partir de aí se realizar análises das modalidades de ação do Estado sob a forma de políticas públicas. Contudo, não se pode olvidar das especificidades e peculiaridades de cada local nessas ações governamentais, destacando-se que a atuação dos órgãos ambientais deve ser notadamente técnica, atentando-se à legislação pátria e não aos interesses privados, bem como aos propósitos político-partidários (GUERRA; GUERRA, 2012, p. 42-43).

A questão da participação cidadã nos problemas e situações ambientais conforme Mirra (2010), pode e deve ser de forma a inibir ou suprimir a ação do Poder Público quando verificada a sua atuação ilegal ou inconstitucional, mas também de forma a integrar e reforçar a ação estatal, através da colaboração não só de indivíduos como de entidades ambientalistas em consultas e audiências públicas, e que possam resultar na correção dos rumos nas políticas ambientais.

Assim, ainda que diante da evolução da participação cidadã no cenário políticojurídico brasileiro, tem-se que é uma questão cada vez mais emergente fundamental para o destino político, econômico e social em escala global. Observe-se, por oportuno, a questão dos refugiados ambientais no cenário internacional. Trata-se de problema emergente com uma nova amplitude conforme leciona Silva (2009, p. 45), não exclusivamente sobre um sintoma ambiental, associam-se a outros fatores, quais sejam políticos, econômicos, sócias e que desembocam na "reticência estatal em acolher tais pessoas".

A efetividade do exercício da cidadania presume ação participativa nas situações em que se verifiquem interesse público ou social, razão pela qual se tem, no caso do Brasil, a característica na Constituição Federal de 1988 de ser eminentemente cidadã e, conforme lição de Machado (2010, p. 139) acrescenta que: "Ser cidadão é sair de sua vida meramente privada e interessar-se pela sociedade de que faz parte e ter direitos e deveres para nela influenciar e decidir". 


\section{CONCLUSÕES}

Diante do que fora proposto no capítulo, tem-se que a cidadania e as questões ambientais estão interligadas, sobressaindo-se o princípio da participação pública para uma efetividade da tutela ambiental por meio de políticas públicas.

Verificou-se que no Brasil, a democracia evolui para uma forma mais participativa da população, sendo mister e cada vez mais necessário o implemento de políticas públicas para sedimento e concretização dessa participação, notadamente quanto aos problemas ambientais. Contudo, observa-se uma crise de informação e de conhecimento a qual deverá ser considera num Estado Democrático de Direito, por meio de políticas públicas adequadas e que expressem as necessidades mais urgentes da sociedade, sem falhas, uma vez que o próprio Estado poderá ser compelido a fazer cumpri-las através de atos praticados pelo cidadão.

Sendo assim, pontua-se que a cidadania possui um conceito sempre em evolução, relacionando-se diretamente com as questões ambientais contemporâneas e com as constantes conquistas de uma sociedade, a qual deverá estar preparada e informada para de forma eficaz realizar verdadeiras ações participativas por via das políticas públicas adequadas, nas quais se tenha por concreto o real interesse público ou social, especialmente para aqueles que são omitidos e descaracterizados em nome do interesse político-econômico.

\section{REFERÊNCIAS}

BUCCI, Maria Paula Dallari. Políticas Públicas: reflexões sobre o conceito jurídico. São Paulo: Saraiva, 2006.

BRASIL. Constituição (1988). Constituição da República Federativa do Brasil. Brasília, DF, Senado, 1998.

CAPRA, Fritjof. A teia da vida: uma nova compreensão científica dos sistemas vivos. Tradução: Newton Roberval Eichemberg. São Paulo: Cultrix, 2006.

CARVALHO. José Murilo de. Cidadania no Brasil: o longo caminho. Rio de Janeiro: Civilização Brasileira, 2007.

DERANI, Cristiane. Direito Ambiental Econômico. 3. ed. São Paulo: Saraiva, 2008.

GUERRA, Sidney. Direitos humanos e Cidadania. São Paulo: Atlas, 2012. 
GUERRA, Sidney; GUERRA, Sérgio. Intervenção Estatal Ambiental: licenciamento e compensação de acordo com a Lei complementar nº140/2011.São Paulo: Atlas, 2012.

MACHADO, Paulo Affonso Leme. Direito Ambiental Brasileiro. São Paulo: Malheiros Editores, 2010.

MARSHALL, Thomaz Humphrey. Cidadania, classe social e status. Rio de Janeiro: Zahar, 1967.

MIRRA, Álvaro Luiz Valery. Participação, processo civil e defesa do meio ambiente no direito brasileiro, 2010.Tese (doutorado em Direito). Faculdade de Direito da Universidade de São Paulo. 2010.

MORIN, Edgar. A via para o futuro da humanidade. Tradução de Edgard de Assis Carvalho; Mariza Perassi Bosco. Rio de Janeiro: Bertrand Brasil, 2013.

PAMPlONA, Danielle Anne. Políticas Públicas: elementos para alcance do desenvolvimento sustentável. Curitiba, Juruá, 2012.

POEMAS. Antes fosse mais leve a carga: avaliação dos aspectos econômicos, políticos e sociais do desastre da Smarco/Vale/BHP em Mariana (MG). Memeo, 2015. Disponível em: http://www.ufjf.br/poemas/files/2014/07/PoEMAS-2015-Antes-fosse-mais-leve-a-cargavers\%C3\%A3o-final.pdf. Acesso em: 23/08/2019.

RIBEIRO, Darcy. O povo brasileiro: a formação e o sentido do Brasil. São Paulo: Companhia das Letras. 2006.

SECCHI, Leonardo. Políticas Públicas: Conceitos, Esquemas de Análise, Casos Práticos. São Paulo: Cengage Learning, 2012.

SILVA, Solange Sanchez. Cidadania ambiental: novos direitos no Brasil. São Paulo: Humanitas/FFLCH/USP, 2000.

SILVA, Solange Teles da. O direito ambiental internacional. Belo Horizonte: Del Rey, 2009.

SILVA, Solange Teles da. Políticas Públicas, desenvolvimento sustentável e sustentabilidade. In: SMANIO, Gianpaolo Poggio; Bertolin, PATRÍCIA Tuma Martins; BRASIL, Patrícia Cristina. (Orgs.) O Direito na fronteira das políticas públicas. São Paulo: Páginas \& Letras, 2015.

SMANIO, Gianpaolo Poggio. Cidadania e Polírticas Públicas. In: SMANIO, Gianpaolo Poggio; Bertolin, PATRÍCIA Tuma Martins; BRASIL, Patrícia Cristina. (Orgs.) O Direito na fronteira das políticas públicas. São Paulo: Páginas \& Letras, 2015. 


\section{$\infty$ ELO DOIS}

\section{Antônio Hélton Vasconcelos dos Santos}

Como discutido no elo anterior, a dialética relação entre a sociedade-natureza apresenta-se dinâmica e com diversos níveis de complexidade. Uma vez que, desde sempre, o homem necessita dos recursos dispostos do meio natural para sua existência de modo a atender as premissas do corpo, mente e espírito. No entanto, o uso dos elementos naturais por parte das ações humanas altera o meio físico, químico, biológico, socioeconômico e cultural, ocasionando diversos impactos ambientais seja de ordem positiva ou negativa.

A intensidade e dimensão dos projetos ou atividades antrópicas engendram múltiplas consequências nos sistemas ecológicos e na sociedade em diferentes escalas espaciais e temporais. Ademais, a insustentabilidade ambiental, enquanto revérbero de algumas atuações humanas, também é promovida pela falta de respeito e compreensão ao equilíbrio e a regeneração dos elementos naturais, comprometendo, assim, a nossa própria qualidade de vida.

Por trás dessa célere degradação tem-se como protagonista o modo civilizatório capitalista que tem como perfil a exploração demasiada dos recursos humanos e naturais para atender aos interesses monetários. Para isso, os grandes proprietários dos meios de produção usurpam o poder, diretamente ou indiretamente, por meio das conjunturas políticas e sociais, colocando a obtenção de lucro acima de tudo e de todos, ignorando que ele também é parte integrante da natureza e que vem sofrendo as consequências desse comportamento predatório. Beneficiam-se, assim, da máquina do Estado, dos sistemas de comunicações midiáticos de massa, do mesmo jeito que da elaboração, aplicação e fiscalização dos quadros regulatórios. Para exemplo desse enredo basta observar como se orquestrou a atual configuração política do Brasil e sua transcendência para as minorias sociais e os elementos da biodiversidade e geodiversidade.

Mesmo diante de tanta perversidade produzida pelos interesses do capital, os empreendimentos ou projetos precisam de ações que visem minimizar seus impactos negativos, seja para enquadrar as atividades na legislação vigente, proporcionarem economia, eficiência e/ou para garantia de sua própria continuidade. Para tal fim, faz-se basilar o diagnóstico das problemáticas vivenciadas por cada ação humana.

O diagnóstico ambiental - DA trata-se da caracterização da qualidade ambiental atual da área de abrangência dos estudos com esse foco, de modo a fornecer conhecimentos 
suficientes para embasar a identificação e, posteriormente, a avaliação dos impactos no meio: físico, biológico, socioeconômico e cultural. Deste modo, tornam-se evidentes nos variados trabalhos com esse cunho, sejam acadêmicos, estudos de impactos ambientais (EIA) ou ainda em relatórios de impactos ambientais (RIMA), a efetivação de tal procedimento.

A elaboração do DA é uma ferramenta que também contribui para Gestão Ambiental GA, visto que, como discorrido anteriormente, aponta as variadas dimensões das ações antrópicas e suas consequências. Permite, igualmente, a tomada de decisões para melhorar as articulações entre os atores e os processos de integração no que concerne a concatenação da sociedade com a natureza em seus mais diferentes níveis de complexidade, adotando práticas mais sustentáveis.

Doravante, a GA ordenará as atividades antrópicas com intuito de propiciar o menor impacto negativo, empregando assim, as melhores técnicas e tecnologias, além da alocação adequada de recursos naturais, humanos e financeiros. Visando assim, aprimorar a potencialidade existente em cada etapa, processo ou ação feita ou que se pretende fazer.

Para que a GA de um território seja eficiente torna-se imprescindível, em alguns casos, a criação e/ou implementação de Políticas Públicas - PPs, posto que tais fomentam um conjunto de programas, planos e atividades realizadas pelo Estado, seja diretamente ou indiretamente, envolvendo a participação de entidades públicas ou privadas que objetivem subsídios para garantia do direito à qualidade ambiental e à cidadania plena dos cidadãos assegurados pela constituição federal brasileira.

As PPs se configuram mediante o reconhecimento por parte da sociedade ou pelos poderes públicos como novos direitos das pessoas, comunidades e bens materiais ou imateriais. Surgem por meio de um diagnóstico ambiental ou para atender a necessidade de gestão territorial, logo possuindo uma inter-relação inerente com a DA e a GA sempre em busca da sustentabilidade ambiental (como mostrado na figura 1).

A esfera da interdisciplinaridade faz parte de todo esse processo, pois só a partir dos diálogos dos saberes é possível a compreensão das interfaces e complexidades existentes na relação do homem com o meio ambiente, assim como, quaisquer elementos que permeiam essa correlação. 
Figura 1 - Inter-relação entre diagnóstico ambiental, gestão, políticas públicas e sustentabilidade.

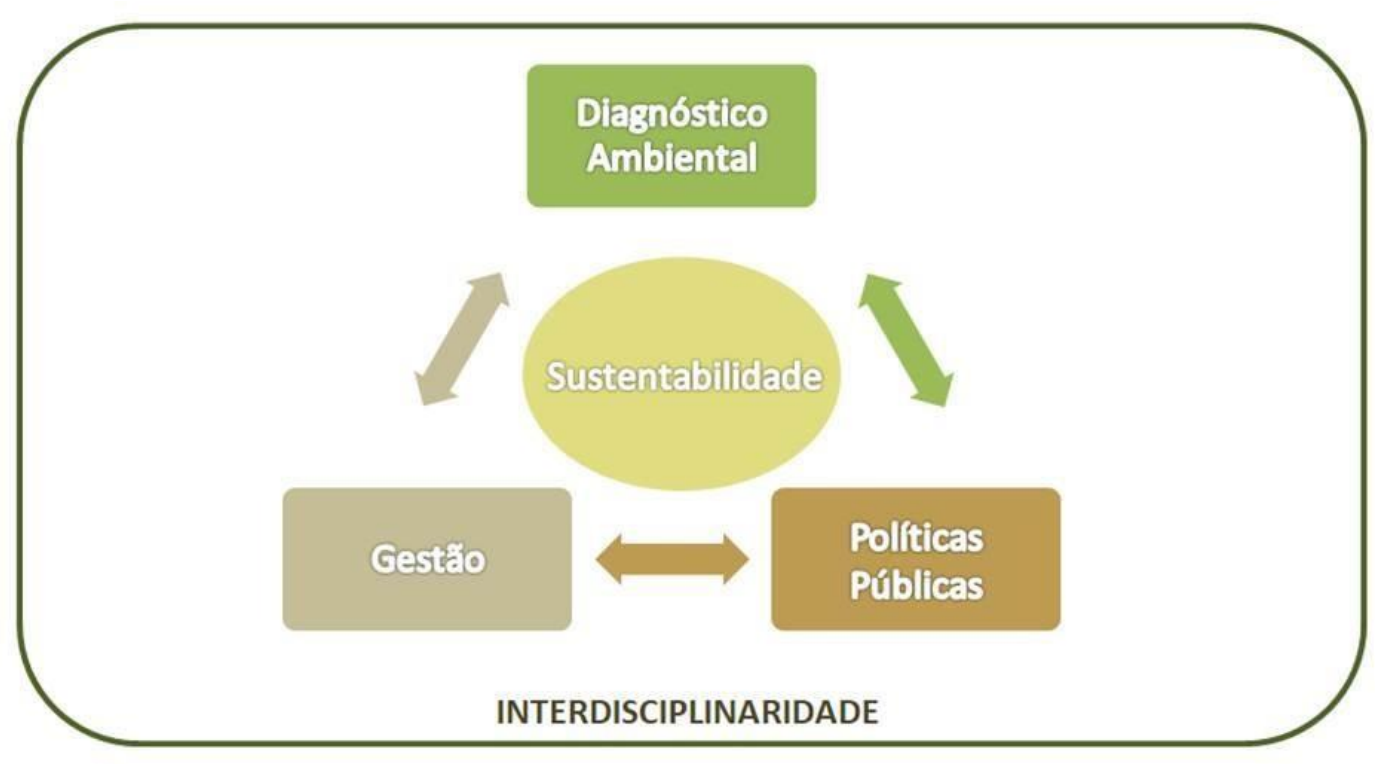

Fonte: Organizadores (2019).

Este fragmento do livro apresenta três importantes capítulos o primeiro intitula-se:

Diagnóstico socioambiental do delta do Parnaíba na região litorânea do Piauí -

Brasil. Tal estudo é extremamente relevante, uma vez que o delta do Parnaíba se apresenta enquanto uma região de grande potencial atrativo-turístico devido a sua beleza singular. Porém, a decorrência desta atividade também incita o desenvolvimento de vários impactos ambientais na área. Com o intuito de contribuir a sustentabilidade local esse trabalho visa diagnosticar tais degradações sugerindo ações minimizadoras.

O segundo: Gestão ambiental em meios de hospedagens no município de Tamandaré-Pernambuco. Faz-se pertinente essa temática, pois o aumento das atividades turísticas em ambientes litorâneos vem beneficiando o crescimento econômico local, mas em contrapartida, contribui para o agravamento dos impactos ambientais decorrentes da utilização desenfreada dos recursos naturais. O presente capítulo buscou analisar os entraves e as oportunidades para a viabilidade da gestão ambiental em meios de hospedagens no Município de Tamandaré, no Litoral Sul do Estado de Pernambuco.

E por fim, o terceiro: A cidadania ambiental por meio de políticas públicas no Brasil. Trata da discussão e análise crítica sobre o exercício da cidadania socioambiental incluindo a participação pública, embasado na compreensão do dever compartilhado no que tange à tutela ambiental perante as legislações vigentes, ratificando, assim, o papel dos instrumentos processuais previstos na Constituição da República Federativa do Brasil. 


\section{FENÔMENOS AMBIENTAIS, COMUNIDADES TRADICIONAIS EGEOPROCESSAMENTO}




\title{
FENÔMENOS AMBIENTAIS, BIODIVERSIDADE DA PAISAGEM E INTERAÇÕES ANTRÓPICAS
}

\author{
Rejane Magalhães de Mendonça Pimentel ${ }^{30}$ \\ Luiz Henrique Gonçalves da Silva ${ }^{31}$
}

\section{INTRODUÇÃO}

A integração entre diferentes fenômenos ambientais, biodiversidade da paisagem e interações antrópicas vem sendo objeto de investigação há muito tempo, entretanto, nunca se fez tão urgente o desenvolvimento de novas pesquisas e a aplicação dos resultados obtidos.

As investigações têm sido desenvolvidas visando a conservação da biodiversidade, especialmente considerando as mudanças climáticas, que são mais evidentes a cada dia, e causadoras de grandes e extensos prejuízos e riscos à manutenção dos organismos vivos em geral.

Apesar das evidências de um desequilíbrio no planeta, não apenas os gestores públicos, a população em geral também, não têm se conscientizado o suficiente para alterar seus padrões de comportamento, os quais não contribuiriam para, ao menos, minimizar os efeitos negativos, a curto, médio e longo prazos.

Abordaremos, neste capítulo, alguns dos aspectos que envolvem a interação entre a vegetação e as ações antrópicas, sempre visando contribuir para a conscientização da importância da participação integrada entre pesquisadores, gestores públicos e a população em geral, na preservação do equilíbrio do ecossistema de áreas urbanizadas.

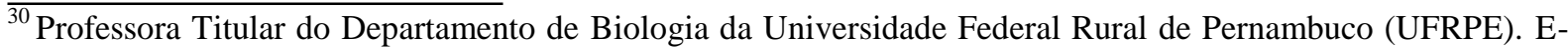
mail: rejanemmpimentel@gmail.com.

${ }^{31}$ Graduando do curso de Bacharelado em Engenharia Florestal pela Universidade Federal Rural de Pernambuco (UFRPE). Membro participante do Grupo de Pesquisa Fitomorfologia Funcional e Interações Antrópicas FITANTROP.
} 
Aspectos relativos às abordagens que consideramos mais relevantes aos fenômenos ambientais, à biodiversidade da paisagem e interações antrópicas serão apresentadas, sempre enfatizando as temáticas que estão associadas à preservação de uma melhor qualidade de vida para a população humana.

Buscamos informar, utilizando uma linguagem, simplificada e direta, sobre aspectos relevantes e que propiciem um despertar ao leitor para uma nova visão e participação, no dia a dia, com ações que contribuam para possíveis mudanças positivas para uma maior e melhor interação do homem com a vegetação em áreas urbanizadas.

É de responsabilidade de todos nós, habitantes deste planeta Terra, apresentar atitudes que, ao menos, minimizem os efeitos negativos de ações inadequadas à uma perspectiva de vida com qualidade, para a população atual e para as gerações futuras.

\section{FENÔMENOS AMBIENTAIS}

Os fenômenos ambientais de maior evidência, em função de sua importância, gravidade e riscos a população humana, estão associados com a crescente urbanização e consequentes problemas causados por ela.

Entre os diferentes fenômenos ambientais que mais causam problemas para os organismos vivos, especialmente em áreas urbanizadas, estão as mudanças climáticas. Estas, por sua vez, são verificadas principalmente através do aumento da temperatura e desequilíbrio na distribuição da precipitação, causando diversos problemas, a todos organismos que fazem parte daquele ecossistema.

O aumento da temperatura no planeta, vem sendo um dos fenômenos ambientais sob investigação em todo o mundo, tem causado inúmeros problemas e prejuízos à humanidade. Uma das causas do aumento da temperatura é a supressão da vegetação, na maioria das vezes, para ser substituída pela construção de edificações ou asfaltamento de vias para veículos automotivos. A ausência de uma adequada substituição da vegetação suprimida, está a sua substituição por outras espécies incapazes de minimizar os efeitos negativos em níveis considerados adequados, desde o favorecimento do aumento da temperatura do ar, passando pela manutenção da beleza paisagística, até um risco à conservação da biodiversidade vegetal.

Entre os diversos efeitos deste aumento na temperatura está o fenômeno conhecido como Ilhas de Calor, estudado por pesquisadores do mundo inteiro (BEZERRA et al., 2013ab; 
CASTILHO; TEIXEIRA, 2016; LEVERMORE et al., 2018; MENDES et al., 2019; RIZVI et al., 2019; PARSAEE et al., 2019).

A formação destas ilhas de calor é resultante de fatores variados, desde a construção desordenada de edificações, associado a supressão da vegetação nativa, até a pavimentação de vias com material de variados efeitos interativos com a radiação incidente sobre ele.

O recobrimento de vias promove o aumento da temperatura e a impermeabilização da superfície do solo, diminuindo a infiltração de água proveniente da chuva, especialmente quando ocorre com grande intensidade em curtos intervalos de tempo. Esse recobrimento ocorre de diferentes modos: pavimentação flexível (bases granulares e revestimento asfáltico), pavimentação semirrígida (base cimentada e revestimento flexível), pavimentação rígida (placas de concreto) e pisos intertravados (pequenos blocos de concreto), estes últimos mais interessantes por permitir a permeabilização da água das chuvas, evitando seu acúmulo e problemas consequentes disto (MAPA DA OBRA, 2019).

A qualidade dos materiais utilizados nas edificações e pavimentação de vias e calçadas influenciam na transferência de calor em áreas urbanizadas. A escolha destes materiais, muitas vezes, considera apenas a beleza estética e não sua influência e participação nas relações com a radiação solar e consequente dissipação do calor no ambiente (atmosfera).

O uso e cobertura do solo é objeto de investigação, quando associado à formação das ilhas de calor (BRITES et al., 2018). A presença da vegetação influencia na amenização da temperatura de suas imediações. A temperatura pode apresentar reduções de até mais de $2^{\circ} \mathrm{C}$ (SILVA; PIMENTEL, 2019), contribuindo sensivelmente para o conforto térmico das pessoas que circulam em suas proximidades. Neste estudo, a espécie Syzygium malaccense (L.) Alston (família Myrtaceae), vulgarmente conhecida como jambeiro, apresentou uma redução de $2,7^{\circ} \mathrm{C}$ na temperatura nas imediações logo abaixo da copa da árvore quando comparada à temperatura de um local completamente exposto à radiação solar.

Este fato é mais fortemente percebido pela população que transita ou reside nas proximidades de áreas verdes, parques e praças. Brites et al. (2018) detectaram temperaturas reduzidas nas áreas mais próximas da vegetação arbórea, entretanto estudos mostraram a contribuição de pequenos canteiros para a amenização da temperatura (ROCHA, 2011).

Estudos foram realizados com o uso de ferramentas de sensoriamento remoto, visando contribuir com informações abrangendo grandes áreas urbanizadas e a participação da presença da vegetação na amenização da temperatura do ar, aumento dos valores de umidade relativa do ar e, consequentemente, um aumento no conforto térmico (SANTANA, 2014). 
Muitos são os exemplos que permitem constatar a substituição de áreas com cobertura de vegetação pela ocupação de edificações (Figura 1).

Figura 1 - Imagem adaptada do Google Earth, mostrando o aspecto geral da antropização sobre a vegetação nativa em um bairro da cidade do Recife-PE. A. Imagem de 2009, seta apontando vegetação presente; B. Imagem de 2016, seta apontando vegetação suprimida e área com edificações.

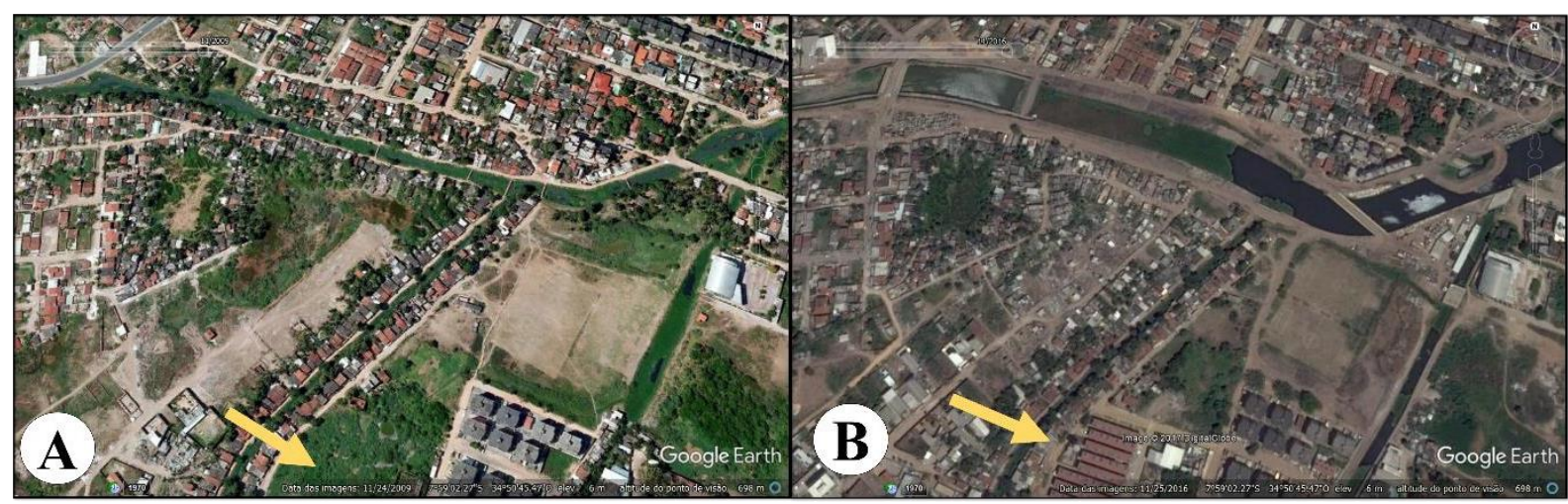

Fonte: Organização dos autores.

Nos grandes centros urbanos, a ausência dessa vegetação traz consigo, como consequência, fenômenos ambientais que representam uma diminuição da qualidade de vida da população humana que ali reside.

Dentre esses fenômenos, os mais relevantes que causam maior desconforto para a população são o aumento na temperatura do ar atmosférico e a menor infiltração da água proveniente da precipitação. As principais causas para estes problemas são o diferente uso e ocupação do solo, aumento de material particulado em suspensão e poluição atmosférica por gases tóxicos devido a ação de veículos automotivos, além da queima de combustíveis fósseis, diminuição na velocidade dos ventos pela existência de edifícios e consequente formação de ilhas de calor.

Um dos fatores que desperta a atenção dos pesquisadores é relativo à saúde da população humana, especialmente quanto ao aparelho respiratório e problemas de pele (MENDONÇA, 2003; SANTANA et al., 2014).

A presença da vegetação urbana se mostra altamente eficaz em minimizar estes desconfortos através da prestação de serviços ambientais, através de mecanismos fisiológicos vitais, como a fotossíntese (produção de matéria orgânica). Um dos efeitos mais notórios é a minimização da temperatura, pela interceptação dos raios solares incidentes sobre a superfície das folhas, e o aumento da umidade relativa do ar, em consequência da evapotranspiração durante a fotossíntese. Ao mesmo tempo, espécies vegetais com folhas grandes auxiliam na 
amenização da quantidade de materiais particulados em suspensão na atmosfera, através da consequente deposição em sua superfície. Isto é particularmente mais eficiente se as folhas apresentarem uma superfície pilosa; quanto maior for a quantidade e, dependendo do tipo do pelo, maior será a quantidade de particulados depositados sobre elas.

Todos estes fatores deveriam ser considerados no momento da seleção das espécies a serem utilizadas na arborização, contribuindo para uma melhor qualidade de vida da população humana. A presença da vegetação, constituída por espécies com caracteres atuantes na minimização dos efeitos negativos da intensa quantidade de edificações e asfaltamento de vias, representam melhor qualidade de vida para a população humana.

Um aumento nos problemas de saúde da população em áreas urbanizadas foi constatado como consequência da poluição atmosférica e aumento da temperatura e incidência de radiação solar, especialmente pela supressão da vegetação (O'LENICK et al., 2019).

\section{BIODIVERSIDADE DA PAISAGEM}

A paisagem de áreas urbanizadas, independentemente de sua extensão, é fortemente impactada pela quantidade e diversidade biológica da vegetação estabelecida nela. O conceito de biodiversidade é variado quanto aos níveis de organização biológica a ser considerado. Considerando fatores como a diversidade genética e a riqueza de espécies encontrada em centros urbanos, é bastante variada a biodiversidade da paisagem. Não devemos esquecer a participação de espécies endêmicas e, especialmente, as exóticas, que foram introduzidas, em variadas extensões e por diferentes motivos nas áreas urbanizadas.

Estudos abordando a diversidade da vegetação em áreas urbanizadas, considerando a riqueza de espécies em função do número delas em uma determinada área, classificam como diversidade alfa (MAGURRAN, 1988; SZLAVECZ; WARREN; PICKETT, 2011).

A identificação botânica das espécies estabelecidas em áreas urbanizadas auxilia nas ações de manejo, especialmente naquelas de substituição, por qualquer motivo, de uma planta por outra. Contribuições variadas estão presentes em muitas publicações, independente dos objetivos destes trabalhos, informando sobre espécies nativas e exóticas (SOARES et al., 2008; ROCHA; PIMENTEL; BARRETO, 2012; LACERDA et al., 2013).

A crescente urbanização se deve, na maioria das vezes, à migração da população de regiões, sob a ação de condições climáticas desfavoráveis ao cultivo de plantas utilizadas para 
o consumo e comercialização, as quais produzem uma renda capaz de manter estas pessoas em seus locais de origem. Historicamente este fenômeno é conhecido como êxodo rural e, no Brasil, a região Nordeste é a que mais sofreu com isto. Nas épocas de seca no semiárido nordestino é comum a evasão da população da zona rural para a zona urbana.

Entre as desvantagens causadas pela crescente urbanização, como resultado da migração da população que depende de atividades rurais, está o aumento na ocupação do solo com construções para moradia e algum tipo de comércio, capaz de garantir sua permanência e de suas famílias.

Entretanto, deve-se ter um planejamento bem estruturado de como conduzir o uso e a ocupação do solo. A arborização de uma área urbanizada, independentemente de sua extensão, considerando, principalmente, as espécies a serem utilizadas. A escolha de uma espécie inadequada acarretará dificuldades, como danos à rede elétrica, pelo desenvolvimento da parte aérea da árvore, através da emissão de ramos e folhas, e danos causados às calçadas pelo sistema radicular, muitas vezes sem o espaço adequado ao seu desenvolvimento.

Em grande parte das cidades brasileiras foram utilizadas espécies exóticas, das quais não se tinha conhecimento das características de crescimento e desenvolvimento, causando prejuízos e reduzindo ou impossibilitando o uso das calçadas pelos transeuntes. Isto é particularmente agravado no caso do deslocamento de pessoas com dificuldades de mobilidade. A introdução de espécies exóticas também pode interferir no desenvolvimento adequado de espécies nativas que persistem em áreas urbanas, algumas vezes por reduzir o número de animais polinizadores naturais, por redução ou impedimento dos processos de produção e desenvolvimento adequado dos frutos. Soma-se a redução dos representantes naturais locais, reduzindo, consequentemente, a biodiversidade da flora nativa.

As árvores submetidas aos estresses promovidos pelo ambiente urbano têm apresentado maiores evidências de risco à sua manutenção e se faz importante a identificação de caracteres indicadores de sua condição biológica, especialmente aquela relativa às suas funções vitais, como a fotossíntese e a respiração.

Diferentes condições ambientais podem proporcionar alterações morfológicas, fisiológicas e anatômicas em indivíduos vegetais (GHEORGHE; ION, 2011; COSTA et al., 2015). Alterações estas que influenciam fortemente nos serviços ambientais providos pela vegetação. 
Uma das vantagens da presença de vegetação em áreas urbanizadas é a redução na propagação de ruídos diversos, especialmente daqueles provenientes dos veículos automotivos (KLINGBERG et al., 2017).

Além disso, minimiza os efeitos do acúmulo de água em ocasiões de fortes precipitações em períodos curtos, particularmente pelo fato de um certo volume da chuva ficar retido na parte aérea das plantas, sobre as folhas e ramos (KERMAVNAR; VILHAR, 2017).

\section{INTERAÇÕES ANTRÓPICAS}

Um planejamento adequado quanto à seleção e manutenção da vegetação em áreas urbanizadas é fundamental para uma melhor qualidade de vida da população humana. Este se faz mais relevante quando consideramos a velocidade no crescimento urbano e a desvalorização na manutenção da vegetação. Qualquer descuido neste planejamento pode resultar no aumento dos problemas encontrados em áreas urbanizadas, particularmente naquelas de grandes dimensões (BRITES et al., 2018).

A ativa participação dos gestores públicos, quanto às ações que envolvem o bemestar e saúde da população humana, pressupõe uma ativa interação com pessoal qualificado e informado sobre as possíveis alternativas para a solução de determinados problemas. Isto é particularmente verdade quando consideramos os impactos antropogênicos gerados e que provocam um desequilíbrio no ambiente, mostrando uma inadequação entre a sociedade e a natureza.

O uso do sensoriamento remoto, associado aos índices de vegetação, é um dos instrumentos mais utilizados, atualmente, pelos gestores ambientais para monitorar as condições da vegetação e os impactos causados pela urbanização, além de informar dados para a elaboração de novas políticas públicas adequadas (BILAR, 2018).

A população que reside em ambientes urbanos também causa danos ao meio ambiente através da poluição. Em cidades onde as políticas de destinação de resíduos sólidos são deficitárias ou não atendidas pela população, são diversas as complicações causadas pelo lixo, entupimento de bueiros, canaletas, acúmulo de lixo na rede de esgoto e nos corpos hídricos. Em Recife, por exemplo, pode-se observar o caso do Rio Capibaribe, que, ao longo dos anos, vem se apresentando cada vez mais poluído. Isto mostra a importância do 
desenvolvimento de projetos de pesquisa e extensão voltados para a conscientização ambiental da população.

Sabemos que a vegetação é um componente imprescindível para uma cidade, e somente a atuação em conjunto entre a população e os órgãos governamentais poderá minimizar os impactos causados pela urbanização, melhorando a qualidade de vida dos residentes dessas áreas, mantendo a biodiversidade local e minimizando os fenômenos ambientais negativos causados pela urbanização.

\section{REFERÊNCIAS}

BEZERRA, M. I. L.; SANTOS, J. S.; AGUIAR, A. P. Ilhas de Calor: Importância da Vegetação na Amenização Climática em João PessoalPB. Revista Brasileira de Geografia Física, v. 6, n. 5, p. 1499-1516, 2013a.

BEZERRA, P. T. DA C.; LEITÃO, M. DE M. V. B. R.; AZEVEDO, P. V. Ilhas de Calor e Desconforto Térmico no Semiárido Brasileiro: Um Estudo de Caso na Cidade de PetrolinaPE. Revista Brasileira de Geografia Física, v. 6, n. 3, p. 427-441, 2013 b.

BEZERRA, P. T. DA C.; LEITÃO, M. DE M. V. B.; AZEVEDO, P. V. Ilhas de Calor e Desconforto Térmico no Semiárido Brasileiro: Um Estudo de Caso na Cidade de PetrolinaPE. Revista Brasileira de Geografia Física, v. 6, n. 3, p. 427-441, 2013.

BILAR, A. B. C.; PIMENTEL, R. M. M.; CERQUEIRA, M. A. Monitoramento da cobertura vegetal através de índices biofísicos e gestão de áreas protegidas. Geosul, v. 33, p. 236-259, 2018.

BRITES, D. I. S.; ALBA, E.; MARCHESAN, J.; SILVA, E. A.; PEREIRA, R. S. Monitoramento de ilhas de calor utilizando imagens de média resolução espacial. Revista Brasileira de Geografia Física, v. 11, n. 3, p. 948-958, 2018.

CASTILHO, C. J. M.; TEIXEIRA, A. F. DE M. O uso da natureza no processo de construção do urbano: quem tem tido direito. aos ventos marítimos em Recife-Brasil? Journal of Environmental Analysis and Progress, v. 1, n. 1, p. 13-23, 2016.

GHEORGHE, J. F.; ION, B. The Effects of Air Pollutants on Vegetation and the Role of Vegetation in Reducing Atmospheric Pollution. In: KHALLAF, M. (Ed.). The Impact of Air Pollution on Health, Economy, Environment and Agricultural Sourcesp, p. 241-280, 2011.

KERMAVNAR, J.; VILHAR, U. Canopy precipitation interception in urban forests in relation to stand structure. Urban Ecosyst., v. 20, p. 1373-1387, 2017. 
KLINGBERG, J.; BROBERG, M.; STRANDBERG, B.; THORSSOND, P.; PLEIJEL, H. Influence of urban vegetation on air pollution and noise exposure - A case study in Gothenburg, Sweden. Science of The Total Environment, v. 599-600, p. 1728-1739, 2017.

LACERDA, M. A.; SOARES, F. DE S.; COSTA, J. P. M.; MEDEIROS, R. DE S.;

MEDEIROS, E. N.; CARVALHO, J. A.; SILVA, Z. L. Levantamento Florístico da Arborização Urbana nas Principais Vias Públicas do Município de Boa Ventura-PB. Revista Brasileira de Gestão Ambiental, v. 7, n. 4, p. 12-16, 2013.

MAPA DA OBRA. Disponível em: https://www.mapadaobra.com.br/capacitacao/conheca-osdiferentes-tipos-de-pavimentos-para-vias-publicas/. Acesso em: 23/04/2019.

MENDES, T. G. DE L.; ANJOS, R. S.; SANTOS, T. N.; MOREIRA, A. B.; NÓBREGA, R. S. Abordagem científica sobre ilhas de calor em Recife-PE. Journal of Environmental Analysis and Progress, v. 4, n. 1, p. 1-13, 2019.

O'LENICK, C. R.; WILHELMI, O. V.; MICHAEL, R.; HAYDEN, M. H.; BANIASSADI, A.; WIEDINMYER, C.; MONAGHAN, A. J.; CRANK, P. J.; SAILOR, D. J. Urban heat and air pollution: A framework for integrating population vulnerability and indoor exposure in health risk analyses. Science of the Total Environment, v. 660, p. 715-723, 2019.

PARSAEE, M.; JOYBARI, M. M.; MIRZAEI, P. A.; HAGHIGHAT, F. Urban heat island, urban climate maps and urban development policies and action plans. Environmental Technology \& Innovation, v. 14, Art. 100341, 16p., 2019.

RIZVI, S. H.; ALAM, K.; IQBAL, M. J. Spatio -temporal variations in urban heat island and its interaction with heat wave. Journal of Atmospheric and Solar-Terrestrial Physics, v. 185 , p. 50-57, 2019.

ROCHA, R.; PIMENTEL, R. M. M.; BARRETO, R. C. Censo da Arborização Viária de um Bairro da Cidade do Recife, Pernambuco, com a Utilização de um Sistema de Informação Geográfica. Revista Brasileira de Geografia Física, v. 2, p. 285-301, 2012.

ROCHA, L. M. V.; SOUZA, L. C. L.; CASTILHO, F. J. V. Ocupação do solo e ilha de calor noturna em avenidas marginais a um córrego urbano. Ambient. Constr., v. 11, n. 3 p. 161$175,2011$.

SILVA, L. H. G.; PIMENTEL, R. M. M. Estrutura morfológica foliar da arborização urbana na manutenção do conforto térmico. Journal of Environmental Analysis and Progress, v. 4, n. 1, p. 104-109, 2019.

SOARES JR., R. C.; ALMEIDA JR., E. B.; PESSOA, L. M.; PIMENTEL, R. M. M.;

ZICKEL, C. S. Flora do Estrato Herbáceo em Um Fragmento Urbano de Floresta AtlânticaPE. Revista de Geografia, v. 25, n. 1, p. 35-49, 2008.

SZLAVECZ, K.; WARREN, P.; PICKETT, S. Biodiversity on the Urban Landscape. In: CINCOTTA, R. P.; GORENFLO, L. J. (eds.). Human Population: Its Influences on Biological Diversity. Ecological Studies, v. 214, Cap. 6, pp. 75-101, 2011. 


\title{
INTERAÇÕES ANTRÓPICAS NO AMBIENTE: SENSORIAMENTO REMOTO NA IDENTIFICAÇÃO DE ALTERAÇÕES NA PAISAGEM
}

\author{
Gabriela Macêdo Aretakis de Almeida ${ }^{32}$ \\ Rejane Magalhães de Mendonça Pimente ${ }^{33}$ \\ Carolina Alves Collier de Almeida ${ }^{34}$ \\ Miguel Santana de Almeida Neto ${ }^{35}$
}

\section{INTRODUÇÃO}

Atividades humanas, como o cultivo agrícola e o pastoreio, a extração seletiva de madeira e as atividades ligadas à urbanização, modificam a paisagem natural dos ecossistemas, gerando barreiras que podem alterar a dinâmica populacional e a manutenção das espécies que vivem nestes ambientes (RESASCO et al., 2017). De acordo com Tabarelli et al. (2004), a ampla modificação das paisagens naturais pela espécie humana propicia a ocorrência de fragmentos florestais imersos em matrizes de ambientes não florestados. Essa substituição de áreas de vegetação nativa por áreas não florestadas e ocupadas pelas atividades humanas pode acarretar diversas mudanças ambientais. Alguns autores apontam, como resultados destas modificações, a elevação da temperatura (NICHOL, 1994), o aumento

\footnotetext{
${ }^{32}$ Professora do Departamento de Tecnologia e Ciências Sociais (DTCS - Campus Juazeiro) da Universidade do Estado da Bahia (UNEB). Doutora em Desenvolvimento e Meio Ambiente pelo Programa de pós-graduação em Desenvolvimento e Meio Ambiente (PRODEMA) da Universidade Federal de Pernambuco (UFPE). E-mail: gabiaretakis@ hotmail.com.

${ }^{33}$ Professora Titular do Departamento de Biologia da Universidade Federal Rural de Pernambuco (UFRPE).

${ }^{34}$ Professora do Instituto Federal de Educação, Ciência e Tecnologia do Sertão Pernambucano (IFSERTÃO-PE). Doutora em Etnobiologia e Conservação da Natureza pela Universidade Federal Rural de Pernambuco, UFRPE, Brasil. E-mail: carol.collier@ hotmail.com.

${ }^{35}$ Professor do do Instituto Federal de Educação, Ciência e Tecnologia do Sertão Pernambucano (IFSERTÃOPE). DOUTOR em Etnobiologia e Conservação da Natureza pela Universidade Federal Rural de Pernambuco, UFRPE, Brasil. E-mail: miguel.almeida@ifsertao-pe.edu.br.
} 
da evapotranspiração nos vegetais (MATLACK, 1993) e a diminuição da umidade relativa do solo (KAPOS, 1989).

Ambientes que têm suas condições alteradas podem induzir respostas nos organismos ali estabelecidos. Nas espécies vegetais, essa tolerância às adversidades ambientais pode ser observada por meio de ajustesem sua estrutura anatômica, morfológica e, consequentemente, em sua fisiologia. Considerandoas variações nos parâmetros morfoanatômicos das folhas, podem ser feitas inferências com relação à resiliência e susceptibilidade das espécies às novas condições impostas pelo meio. A compreensão dessas respostas das plantas submetidas às distintas condições ambientais pode ser realizada por meio de avaliações, em escala microscópica, na arquitetura morfoanatômica das folhas, e macroscópica, nos estudos de dosséis em paisagens. Essas observações podem ser realizadas empregando-se técnicas associadas de sensoriamento remoto, que possibilitam o estudo dos dosséis, bem como a caracterização através da observação de parâmetros espectrais, em nível microestrutural. Utilizar técnicas de sensoriamento remoto em estudos de dossel em ambientes florestais permite uma análise multiespectral da cobertura vegetal e identificação de possíveis modificações de parâmetros ambientais ocasionados por mudanças naturais ou humanas (SANTANA et al., 2016).

\section{INFLUÊNCIA HUMANA NA FRAGMENTAÇÃO FLORESTAL E CONSEQUÊNCIAS DECORRENTES}

Desde os primórdios de sua existência, a espécie humana vem alterando as condições do ambiente, visando assegurar sua sobrevivência. Com o passar dos séculos, o desenvolvimento da sociedade levou ao consequente aumento da população humana, que chegou a apresentar um crescimento exponencial a partir do século XVIII (PINTO-COELHO, 2007). Esse crescimento atingiu seu apogeu em meados de 1960, após a segunda revolução industrial, e perdura até a atualidade, com o número de habitantes no planeta ultrapassando os sete bilhões no ano de 2017 (ONU, 2019).

Para que a expansão humana se tornasse possível, extensas áreas florestadas foram gradativamente transformadas e substituídas, havendo a utilização de seus recursos para fins humanos. No entanto, segundo Cidin e Silva (2004), a pressão exercida pela população humana mundial vem afetando de modo irreversível os ecossistemas naturais, uma vez que a utilização de recursos supera a capacidade de suporte destes ambientes, além de atuar 
modificando a paisagem. Acerca disto, estima-se que aproximadamente $50 \%$ da cobertura terrestre do planeta foi submetida a impactos diretos decorrentes de ações humanas (HOOKE et al., 2012).

O crescimento da população humana e todos os reflexos decorrentes são reconhecidos como uma das principais causas de degradação dos ecossistemas naturais. Entre as consequências dos impactos promovidos por tais atividades, que levam à conversão do habitat natural para usos humanos, há a ocorrência da fragmentação das florestas e habitats. O processo de fragmentação vem sendo estudado com diferentes enfoques, os quais, geralmente, buscam entender as consequências deste processo sobre as condições ambientais e a biota, bem como os resultados destas alterações sobre as comunidades humanas. O desmatamento promovido pela substituição de áreas florestadas para construção de casas, estradas, áreas urbanas, agropecuárias e industriais, estão entre os principais fatores causadores da fragmentação (HADDAD et al., 2015). Através das diversas formas de uso da terra, as pessoas promovem a formação de fragmentos descontínuos em áreas onde, anteriormente, haviam florestas contínuas (RESASCO et al., 2017).

De acordo com Luizão (2007), a fragmentação florestal produz alterações climáticas responsáveis por distúrbios nas bacias hidrográficas, além da degradação de recursos naturais e erosão dos solos. Entre as alterações ambientais elencadas podem ser observadas mudanças nos movimentos de calor, nos ventos, no fluxo de radiação, na água e na disponibilidade de nutrientes do solo (LUIZÃO, 2007). Além dessas consequências ambientais, há a ocorrência do chamado efeito de borda, que revela a diferença abrupta ocorrida na interface entre os fragmentos florestais e a matriz onde estes estão imersos, uma vez que a borda desses fragmentos passa a ficar exposta à radiação solar e aos ventos mais intensos (DELAMÔNICA et al., 2001).

De modo imediato, os ambientes que passaram a ser fragmentados apresentam novas condições, sob as quais os organismos precisam se adequar para sobreviver. Após o desmatamento, formam-se ilhas florestais isoladas e desconectadas que eliminam organismos vegetais e geram barreiras físicas para as espécies. Consequentemente, ocorre a diminuição do número de indivíduos das populações, que reduz a variação genética, podendo ocasionar, em longo prazo, a extinção de espécies (KAGEYAMA e GANDARA, 1998; DELAMÔNICA et al., 2001). Adicionalmente, processos ecológicos como a polinização, a ciclagem de nutrientes, a dispersão de sementes e as relações entre as espécies são afetados, acarretando a perda de diversidade biológica (YU et al., 2015). Ao analisar tais mudanças, nota-se a 
influência exercida pela área que circunda os fragmentos na dinâmica e estrutura das populações e comunidades estabelecidas em seu interior. Diante disso, vê-se a importância de serem desenvolvidos estudos em escala de paisagem, visando avaliar a influência humana, bem como suas consequências na formação dos fragmentos florestais e matriz circundante.

\section{Ecologia da paisagem e uso de geotecnologias}

Uma paisagem pode ser entendida como um recorte heterogêneo da realidade, que foi historicamente construído, sendo passível de ser compreendida e interpretada pelo observador (LUI e MOLINA, 2009). Essa definição permite a associação de fatores físicos, ambientais e socioculturais na construção das paisagens, considerando a relação entre as pessoas e o ambiente. A escala de observação de paisagem é considerada como a primeira instância na qual a interação entre as pessoas e o ambiente pode ser bem avaliada, em função dos efeitos das ações humanas no ambiente natural tornarem-se visíveis (BÜRGI et al., 2004). Por esse motivo, diversas áreas científicas se interessaram em desenvolver estudos nesta temática, visando compreender a relação entre as pessoas e o ambiente ao longo do tempo. Nos estudos de paisagem, para cada área do conhecimento que utiliza essa escala de observação, diversos fatores podem ser incluídos em sua interpretação e compreensão, como fatores ecológicos, estéticos, culturais e, até mesmo, políticos (POLETTE, 1999). Essa ampla gama de fatores torna os estudos de paisagem interdisciplinares e muitas vezes complexos.

Entre as linhas de pesquisa que desenvolvem estudos em escala de paisagem está a Ecologia da Paisagem. Essa linha de pesquisa surgiu em meados do século XX, desenvolvendo-se, inicialmente, na Alemanha e Holanda, buscando a promoção de pesquisas que envolvessem o ser humano e a sociedade, juntamente com o ambiente físico natural (NUCCI, 2007). Pesquisadores da geografia e da ecologia começaram a abordar em seus estudos a relação entre as pessoas, considerando suas práticas socioeconômicas e culturais, além das paisagens construídas, ou não, por elas (VITTE, 2007), desenvolvendo a Ecologia da Paisagem, de modo interdisciplinar. De acordo com Turner (2005), a Ecologia da Paisagem pode ser definida como o estudo da interação entre os processos ecológicos e os padrões espaciais, considerando um dado recorte ao longo do tempo. Essa definição permite-nos reconhecer a relevância de tais estudos para a atual situação global, uma vez que, a partir de análises dessa temática, podem ser identificados padrões que permitirão predições futuras a respeito, não somente de áreas pontuais, mas com dimensões até mesmo globais.

O uso de geotecnologias, como o sistema de informações geográficas (SIG) e o sensoriamento remoto, tem se mostrado eficaz na compreensão de diversos aspectos 
relacionados aos padrões de mudança espaço-temporal da paisagem. A utilização dessas ferramentas possibilita a análise qualitativa e quantitativa da paisagem (FORMAN, 1995; SANTANA et al., 2016), agregando informações essenciais para estudos de monitoramento e predição de condições futuras das paisagens. As ferramentas de SIG possibilitam análises complexas da composição e configuração das paisagens, permitindo o cruzamento de diversas variáveis (e.g. COLLIER et al., 2015).

Nos estudos de sensoriamento remoto são obtidas medidas acuradas de parâmetros climáticos e da vegetação, por meio de índices calculados a partir da captação da energia refletida ou emitida pelos objetos dispostos na superfície terrestre (FLORENZANO, 2002). Entre os índices calculados para estudos de avaliação de mudanças na vegetação estão o Índice de Vegetação por Diferença Normalizada (IVDN) (Normalized Difference Vegetation Index -NDVI) (ROUSE et al., 1973), o Índice de Água com Diferença Normalizada - IADN, (Normalized Difference Water Index-NDWI) (GAO, 1996), o Índice de Vegetação Ajustado (IVA) (Enhanced Vegetation Index - EVI)(HUETE et al., 1997), o Índice de Área Foliar (IAF) (Leaf Area Index - LAI)(ALLEN et al., 2002), entre outros. Estes índices são indicadores eficazes do crescimento e vigor da vegetação (PONZONI, 2001), e permitem análises, em escala macroscópica, realizada a partir do dossel da vegetação, e microscópica, uma vez que chegam a traduzir a energia refletida até mesmo em nível celular, particularmente das folhas. Desse modo, podem ser conhecidas as mudanças ocorridas na paisagem como um todo, e os fatores que as ocasionaram, que podem incluir alterações naturais e humanas. Além disso, podem ser estudadas respostas da vegetação a tais alterações. Avaliando o modo como a energia é refletida pelas estruturas vegetais, pode-se conhecer as respostas dos vegetais que podem ser relevantes para o monitoramento e diagnóstico ambiental das paisagens.

\section{RESPOSTAS ESPECTRAIS ASSOCIADAS À ESTRUTURA FÍSICA E QUÍMICA FOLIAR}

A radiação incidente sobre a superfície foliar pode ser transmitida, absorvida ou refletida, a depender das características físicas, químicas e fisiológicas deste órgão. O conhecimento destas características foliares, bem como do comportamento espectral, proporcionam a compreensão das respostas dos vegetais às condições de degradação e estresse ambiental (e.g. FERET et al., 2008; MACHADO et al., 2015). Investigações nesse 
sentido tiveram início ainda no final do século XIX, e foram se intensificando por volta da década de 1960, com o maior desenvolvimento do sensoriamento remoto (CARTER e KNAPP, 2001). A avaliação remota permitiu a mensuração da quantidade de radiação refletida pelos objetos dispostos na superfície terrestre. Após essa facilitação, podendo-se obter dados de reflectância, de forma remota, a maior parte das pesquisas passou a abordar a reflectância foliar para a avaliação das respostas espectrais, utilizando, de modo menos frequente, a transmitância e a absorbância (CARTER e KNAPP, 2001). Diante disso, diversos estudos têm avaliado o comportamento da energia incidente sobre a superfície foliar, utilizando metodologias que avaliam a reflectância em nível de dossel (e.g. FRANÇA et al., 2013; SANTANA et al., 2016; YANG et al. 2017), como em folhas individuais (e.g. BALTZER e THOMAS, 2005; GALVÍNCIO e PIMENTEL, 2012; ROTH, 2016).

Em escala mais ampla, em nível de dossel, são utilizados índices multiespectrais que permitem que sejam obtidas medidas de reflectância em diferentes regiões espectrais, como a região do infravermelho, infravermelho próximo e visível (CHAERLE e VAN DER STRAETEN, 2000). Em medidas diretas no órgão foliar, podem ser obtidos dados com maior acurácia, em escala hiperespectral, em bandas espectrais estreitas, com escala de dezenas de nanômetros (CHAERLE e VAN DER STRAETEN, 2000). Esse refinamento de dados possibilita a detecção de assinaturas espectrais específicas para espécies vegetais e permite diversas inferências com relação ao estado fisiológico dos vegetais (CARTER e KNAPP, 2001; BALTZER e THOMAS, 2005; GALVÍNCIO e PIMENTEL, 2012). Os dados provenientes dessas mensurações são relevantes fontes de informação para avaliar o estado fisiológico dos vegetais sob condições naturais ou de estresse ambiental, uma vez que podem ser identificadas faixas do espectro eletromagnético onde ocorrem maior ou menor reflectância, de acordo com a estrutura e composição química das folhas (JACQUEMOUD e BARET, 1990; CARTER, 1991; CARTER, 1993; CARTER e MILLER, 1994; CARTER e KNAPP, 2001).

A influência das características estruturais da folha na reflectância da radiação vem sendo estudada desde o início do século XX, por Willstatter e Stoll (1913, citados por KNIPLING, 1970). De acordo com Knipling (1970), nesta época, esses pesquisadores reconheceram a influência da estrutura interna foliar no mecanismo de reflexão da radiação. Décadas mais tarde, Gates et al. (1965) publicaram um artigo sobre as propriedades espectrais das plantas, enfatizando a relevância de características estruturais, como os espaços intercelulares, além da presença de pigmentos e água nos cloroplastos, e sua interação entre a 
radiação e a folha. Nesta mesma época, pesquisadores realizaram uma compilação de estudos russos com dados de reflectância espectral, registrando diferenças na resposta espectral de folhas de sol e de sombra, em virtude de suas distintas estruturas anatômicas (STEINER e GUTERMANN, 1966). Anos mais tarde, Middleton et al. (1998) identificaram que ambas as superfícies foliares, superior e inferior, também apresentam respostas espectrais distintas. Todos os estudos realizados nesse sentido forneceram embasamento para pesquisas mais recentes sobre a interação entre a estrutura anatômica foliar e a radiação. Sabe-se, atualmente, que as características foliares que irão influenciar a absorbância, a transmitância e a reflectância da radiação incluem caracteres anatômicos, como a espessura da folha, da cutícula e do mesofilo (porção da folha entre as superfícies da epiderme, compreendendo a área que contém o parênquima clorofiliano, responsável pela fotossíntese), além da presença de pigmentos e outros compostos químicos, como clorofilas, antocianinas, carotenoides, fenóis, proteínas, lignina e celulose, bem como características fisiológicas, como o teor de água e eficiência fotossintética (MOHAMED et al., 2000).

$\mathrm{Na}$ estrutura foliar dos vegetais, a cutícula que recobre a epiderme, geralmente transparente, faz com que apenas uma pequena parte da energia radiante incidente sobre superfície foliar seja diretamente refletida, coma maior parte difundida através dela e da epiderme, chegando até as células do parênquima clorofiliano e espaços no mesofilo (KNIPLING, 1970). No entanto, a elevação da incidência luminosa pode levar os vegetais a aumentar a espessura cuticular nas folhas para protegê-los dos efeitos danosos da irradiação direta, resultando em alterações nos valores de reflectância (BALTZER e THOMAS, 2005). Ao atingir a região do mesofilo, parte da radiação que não foi refletida será absorvida para realização das atividades vitais dos vegetais, e outra parte espalha-se para baixo, sendo transmitida (KNIPLING, 1970). No mesofilo, um dos parâmetros mais importantes na determinação da reflectância é a área total das interfaces entre as paredes celulares e o ar, não o volume total de espaço preenchido pelo ar (KNIPLING, 1970). Essa relação entre o espectro de reflectância e o mesofilo foi documentada por Ourcival et al. (1999). Em sua pesquisa com Quercusilex, estes pesquisadores identificaram forte correlação do mesofilo e espessura do parênquima paliçádico com o espectro de reflectância. Knapp e Carter (1998) observaram a relação entre a espessura foliar e a reflectância na região do infravermelho próximo do espectro. Para a região do infravermelho de onda curta, Ceccato et al. (2001) identificaram a estrutura interna e a matéria seca entre os parâmetros responsáveis pelas variações nos valores de reflectância foliar. Na região visível do espectro, a reflectância foliar 
é baixa, em virtude da absorção realizada pelos pigmentos fotossintéticos encontrados nas células do parênquima clorofiliano presente no mesofilo (PENUELAS e FILELLA, 1998).

A estrutura bioquímica e fisiológica dos vegetais produz respostas espectrais observadas, principalmente, na faixa visível do espectro eletromagnético. Esta faixa apresenta elevada absorção de radiação, em virtude da presença de pigmentos foliares como as clorofilas, os carotenos, as xantofilas e as antocianinas (GATES et al., 1965). Uma alternativa para a detecção da composição desses pigmentos na folha é a utilização de medidas de reflectância foliar (PENUELAS e FILELLA, 1998). Segundo Penuelas e Filella (1998), utilizando valores de reflectância nos comprimentos de $675 \mathrm{~nm}$ e a 550 nmdo espectro, podese derivar a concentração de clorofila presente nos vegetais. De acordo com esses autores, a sensibilidade de reflectância é maior no comprimento de $550 \mathrm{~nm}$, quando a concentração de clorofila é de média a elevada, enquanto baixas concentrações desse pigmento mostram maior sensibilidade no comprimento de $675 \mathrm{~nm}$. Chaerle e Van Der Straeten (2001) relatam que as xantofilas, que são responsáveis pela mediação da dissipação térmica da energia absorvida pela clorofila, podem ser quantificadas a partir do comprimento de onda de $531 \mathrm{~nm}$. Essas alterações na reflectância, nos comprimentos de onda na faixa do visível, mostram as respostas dos vegetais às condições de estresse, como resultado da sensibilidade da clorofila aos distúrbios metabólicos (KNIPLING, 1970). Além disso, tais alterações possibilitam a detecção do estado nutricional, da fenologia e da eficiência fotossintética dos vegetais sob tais condições estressantes (PENUELAS e FILELLA, 1998).

Agentes estressores, como a reduzida disponibilidade hídrica, a elevada incidência luminosa, o aumento de temperatura, a poluição atmosférica, a deficiência de nutrientes, a toxicidade ou mesmo as doenças, podem promover alterações no teor de clorofila foliar, resultando em modificações nos valores de reflectância (LARCHER, 1995; LARCHER, 2004). Outros fatores importantes a serem considerados nos estudos sobre as respostas foliares espectrais ao estresse são a disponibilidade de nutrientes do solo, em especial do nitrogênio, que está associado ao teor de clorofila (JOHNSON et al., 1997) e ao conteúdo de água (PENUELAS e FILELLA, 1998; MACHADO et al., 2015). Carter (1993) realizou um estudo buscando avaliar as respostas espectrais foliares a diferentes agentes estressores, como a competição, patógenos, herbicidas, desidratação, entre outros. Nesta pesquisa, este autor identificou que, independentemente do agente estressor, a reflectância visível aumentou, de modo considerável, em especial quanto aos comprimentos de onda de $550 \mathrm{~nm}$, no espectro verde, e de $710 \mathrm{~nm}$, no espectro vermelho. Para o agente de desidratação, este autor observou 
diferenças no espectro amarelo, no comprimento de $584 \mathrm{~nm}$, e no espectro infravermelho, nos comprimentos de $1.400 \mathrm{~nm}, 1.900 \mathrm{~nm}, 2.000 \mathrm{~nm}$ e $2.400 \mathrm{~nm}$. Em outro estudo, Carter e Knapp (2001) registram que as respostas espectrais foliares próximas do comprimento de 700 nm são imprescindíveis para a detecção de estresse nas plantas, fornecendo, inclusive, estimativas da concentração de clorofila nas folhas. Essas pesquisas trazem informações que revelam o potencial da utilização de dados espectrais para a detecção de respostas da vegetação às mudanças ambientais, assim como para a detecção de mudanças ambientais, a partir de respostas foliares.

Estudos que considerem parâmetros abióticos associados a aspectos estruturais, fisiológicos e ecológicos dos vegetais, em locais degradados, são de extrema importância para a manutenção da biodiversidade no ambiente. Investigações dessa natureza revelam informações ecológicas essenciais para o desenvolvimento de planos de manejo e conservação de espécies vegetais em ambientes degradados e urbanizados, mostrando-se úteis para a compreensão dos processos ecológicos e mitigação dos efeitos negativos em áreas degradadas. Além disso, a associação destas abordagens com estudos em escala de paisagem permite uma compreensão mais holística acerca da realidade, incluindo o desenvolvimento de modelos para a compreensão do processo de formação e predição das diferentes paisagens.

\section{REFERÊNCIAS}

ALLEN, R. G.; TASUMI, M.; TREZZA, R. SEBAL (Surface Energy Balance Algorithms for Land). Advance Training and Users Manual - Idaho Implementation, version 1.0. 2002. 97p.

BALTZER, J.L; THOMAS, S.C. Leaf Optical Responses to Light and Soil Nutrient Availability in Temperature Deciduous Trees. American Journal of Botany,v. 92, n. 2, p. 214-223,2005.

BÜRGI, M.; HERSPERGER, A. M.; SCHNEEBERGER, N. Driving forces of landscape change - current and new directions. Landscape Ecology, v.19, n. 2, p. 857-868, 2004.

CARTER, G. A. Primary and Secondary Effects of Water Content on the Spectral Reflectance of Leaves. American journal of Botany,v.78, n.7, p. 916-924, 1991.

CARTER, G. A. Responses of Leaf Spectral Reflectance to Plant Stress. American Journal of Botany, v. 80, n. 3, p. 239-243, 1993. 
CARTER, G. A.; KNAPP, A. K. Leaf optical properties in higher plants: linking spectral characteristics to stress and chlorophyll concentration. American Journal of Botany,v.88, n. 4, p. 677-684, 2001.

CARTER, G. A.; MILLER, R. L. Early Detection of Plant Stress by Digital Imaging within Narrow Stress-Sensitive Wavebands. Remote Sensing of Environment,n. 50, p. 295-302, 1994.

CECCATO, P.; FLASSE, S.; TARANTOLA, S.; JACQUEMOUD, S.; GREGOIRA, J.

Detecting vegetation leaf water content using reflectance in the optical domain. Remote Sensing of Environment, n. 77, p. 22-33, 2001.

CHAERLE, L.; VAN DER STRAETEN, D. Imaging techniques and the early detection of plant stress. TrendsPlant Science, v. 5, n. 11, p. 495-501, 2000.

CIDIN, R.C.P.J.; Silva, R.S. Pegada ecológica: instrumento de avaliação dos impactos antrópicos no meio natural. EstudosGeográficos, v. 2, n. 1, p. 43-52, 2004.

COLLIER, C.A.; ALMEIDA NETO, M.S.; ARETAKIS, G.M.A.; SANTOS, R.E.; OLIVEIRA, T.H.; MOURÃO, J.S.; SEVERI, W.; EL-DEIR, A.C.A. Integrated approach to the understanding of the degradation of an urban river: local perceptions, environmental parameters and geoprocessing. JournalofEthnobiologyandEthnomedicine, v. 11, n. 69, p. $1-13,2015$.

DELAMÔNICA, P.; LAURANCE, W.F.; LAURANCE, S.G. A Fragmentação da Paisagem, In: OLIVEIRA, A.A.; DALY, D.C. (Eds), Florestas do Rio Negro. Schwarcz LTDA, p. 285301. 2001.

FERET, J.; FRANÇOIS, C.; ASNER, G. P.; GITELSON, A. A.; MARTIN, R. E.; BIDEL, L. P. R.; USTIN, S. L.; MAIRE, G.; JACQUEMOUD, S. PROSPECT-4 and 5: Advances in the leaf optical properties model separating photosynthetic pigments. Remote SensingofEnvironment, n. 112, p. 3030-3043, 2008.

FLORENZANO, T.G. Imagens de satélites para estudos ambientais. Oficina de textos, São Paulo, 2002. 16p.

FORMAN, R.T. Land Mosaics: The Ecology of Landscapes and Regions. Cambridge University Press. 1995. 632p.

FRANÇA, L.M.A.;OLIVEIRA, T.H.;PEREIRA, J.A.S.;LINS, T.M.P.;GALVÍNCIO, J.D. Spatial Analysis of Caatinga Vegetation in the Municipality of Ibimirim-PE. Journal of Hyperspectral Remote Sensing, v. 3, n. 3, p. 59-70, 2013.

GALVÍNCIO, J. D.; PIMENTEL, R. M. M. Leaf spectral behavior and chlorophyll content of Mimosa hostilis canopy in a semiarid environment.Journal of Hyperspectral Remote Sensing, n. 01, p. 001-09, 2012. 
GAO, B. C. NDWI - A Normalized Difference Water Index for remote sensing of vegetation liquid water from space. Remote Sensing of Environment, v. 58, p. 257-266, 1996.

GATES, D. M.; KEEGAN, H. J.; SCHLETER, J.C.; WEIDNER, V.R. Spectral Properties of Plants.Applied Optics, v. 4, n. 1, p. 11-20, 1965.

HADDAD,N.M.; BRUDVIG, L.A.; CLOBERT, J.; DAVIES, K.F.; GONZALEZ, A.; HOLT, R.D.; LOVEJOY, T.E.; SEXTON, J.O.; AUSTIN, M.P.; COLLINS, C.D.; COOK, W.M.; DAMSCHEN, E.I.; EWERS, R.M.; FOSTER, B.L.; JENKINS, C.N.; KING, A.J.;

LAURANCE,W.F.;LEVEY, D.J.; MARGULES, C.R.; MELBOURNE, B.A.; NICHOLLS, A.O.; ORROCK, J.L.; SONG, D.; TOWNSHEND, J.R. Habitat fragmentation and its lasting impacton Earth's ecosystems. Science Advances, v. 1, n. 2, p. 1-9, 2015.

HOOKE, R.L.; DUQUE, M.; PEDRAZA GILSANZ, J. Land transformation by humans: a review. GSA Today, v. 22, n. 12, p. 4-10, 2012.

HUETE, A.; DIDAN, K.; MIURA, T.; RODRIGUEZ, E.P.; GAO, X.; FERREIRA, L.G. Overview of the radiometric and biophysical performance of the MODIS vegetation indices. Remote Sensing of Environment, v. 83, n. 1, p. 195-213. 2002.

JACQUEMOUD, S.; BARET, F. PROSPECT: A Model of Leaf Optical Properties Spectra. Remote Sensing of Environment, n. 34, p. 75-91, 1990.

JOHNSON, J. D.; TOGNETTI, R.; MICHELOZZI, M.; PINZAUTI, S.; MINOTTA, G.; BORGHETTI, M. Ecophysiological responses of Fagus sylvatica seedlings to changing light conditions. II. The interaction of light environment and soilfertility on seedling physiology. PhysiologiaPlantarum,n. 101, p. 124-134, 1997.

KAGEYAMA, P.Y.; GANDARA, F.B.; SOUZA, L.M.I. Consequências genéticas da fragmentação sobre populações de espécies arbóreas. Série Técnica - IPEF,v. 12, n. 32, p. 65-70, 1998.

KAPOS, V. Effects of isolation on the water status of forest patches in the Brazilian Amazon. Journal of Tropical Ecology, v. 5, p.173-185. 1989.

KNAPP, A.K.; CARTER,G.A. Variability in leaf optical properties among 26 species from a broad range of habitats. American Journal of Botany,n. 85, p. 940-946, 1998.

KNIPLING, E.B. Physical and Physiological Basis for the Reflectanceof Visible and NearInfrared Radiation from Vegetation. Remote Sensing of Environment,n. 1, p. 155-159, 1970.

LARCHER, W. Physiological plant ecology: Ecophysiology and stressphysiology of functional groups. 3ed., New York: Springer. 1995. 528p.

LARCHER, W. Ecofisiologia vegetal. São Carlos: RiMa Artes e Textos. 2004. 531p. 
LUI, G. H.; MOLINA, S. M. G. Ocupação humana e transformação da paisagem na Amazônia brasileira.Amazônica,v.1, n.1, p. 200-228, 2009.

LUIZÃO, F. J. Ciclos de nutrientes na Amazônia: respostas às mudanças ambientais e climáticas. Ciência e Cultura,v. 9, n. 3, p. 31-36, 2007.

MACHADO, C. C. C.; CORRÊA, P. G.; GALVÍNCIO, J. D.; PIMENTEL, R. M. M. Relação entre parâmetros hídricos e morfoanatômicos foliares e o comportamento espectral de espécies da caatinga utilizando imagem de satélite (ThematicMapperLandsat5). Revista de Geografia,v. 32, n. 1,p. 208-220, 2015.

MATLACK, G. R. Microenvironment variation within and among forest edge sites in the eastern United States. Biological Conservation, v. 66, p. 185-194. 1993.

MIDDLETON, E.M.;WALTER-SHEA, E.A.;MESARCH, M.A.;CHAN, S.S.; RUSIN, R.J. Optical properties of canopy elements in black spruce, jack pine and aspen stands in Saskatchewan, Canada. Canadian Journal of Remote Sensing, v. 24, n. 2, p. 169-186, 1998.

MOHAMMED, G. H.; NOLAND, T. L.; IRVING, D.; SAMPSON, P. H.; ZARCO-TEJADA, T. J.; MILLER, J. R. Natural and stress-induced effects on leaf spectral reflectance in Ontario species. Forest Research Report,n. 156, p. 34, 2000.

NICHOL, J. E. An examination of tropical rain forest microclimate using GIS modeling.

Global EcologyandBiogeographyLetters, v. 4, p. 69-78. 1994.

NUCCI, J. C. Origem e desenvolvimento da ecologia e da ecologia da Paisagem.Revista Eletrônica Geografar,v.2, n.1, p. 77-99, 2007.

ONU - Organização das Nações Unidas. 2019. Disponível em: https://news.un.org/pt/story/2017/06/1589091-populacao-mundial-atingiu-76-bilhoes-dehabitantes. Acessoem: 30 maio de 2019.

OURCIVAL, J. M.; JOFFRE, R.; RAMBAL, S.Exploring the relationships between reflectance and anatomical and biochemical properties in Quercus ilex leaves. New Phytologist, n. 143, p. 351-364, 1999.

PENUELAS, J.; FILELLA, E. Visible and near-infrared reflectance techniques for diagnosing plant physiological status. Trends in Plant Science, v. 3, n. 4, p. 151-156, 1998.

PINTO-COELHO, R.M. Fundamentos em Ecologia. Ed. Artmed. 2007.257p.

POLETTE, M. Paisagem: uma reflexão sobre um amplo conceito. Turismo Visão e Ação, v. 2, n. 3, p. 83-94, 1999. 
PONZONI, F.J. Comportamento espectral da Vegetação. In: MENESES, P. R.; MADEIRA NETTO, J. S. (Eds).Sensoriamento Remoto - Reflectância dos Alvos Naturais. Universidade de Brasília - UnB. Embrapa Cerrados. Brasília, DF. pp. 157-199. 2001.

RESASCO, J.; BRUNA, E.M.; HADDAD, N.M.; BANKS-LEITE, C.; MARGULES, C.R. The contribution of theory and experiments to conservation infragmented landscapes. Ecography, n. 40, p. 109-118, 2017.

ROTH, K. L.; CASAS, A.; HUESCA, M.; USTIN, S. L.; ALSINA, M. M.; MATHEWS, S. A.; WHITING, M. L. Leaf spectral clusters as potential optical leaf functional types within California ecosystems. Remote Sensing of Environment,n.184, p. 229-246, 2016.

ROUSE, J.W.; HASS, R.H.; SHELL, J.A.; DEERING, D.W. Monitoring VegetationSystems in the Great Plains with ERTS. Proceedingsof Third ERTS Symosium,Washington, pp. 309-317, 1973.

SANTANA, M.F.;DELGADO, R.C.;OLIVEIRA-JÚNIOR, J.F.;GOIS, G.;TEODORO, P.E. Variability of the Atlantic Forest based on the EVI index and climate variables in Cunha-SP, Brazil. Revista de CiênciasAgroambientais, v. 14, n. 1, p. 37-44, 2016.

STEINER, D.; GUTERMANN, T. Russian data on spectral reflectance of vegetation, soil, and rock types.Final Technical Report,United States Army European Research Office. 1966. $232 \mathrm{p}$.

TABARELLI, M.; SILVA, J. M. C.; GASCON, C. Forest fragmentation, synergisms and the impoverishment of neotropical forests. Biodiversity and Conservation, v. 13, p. 1419-1425, 2004.

TURNER, M. G.; GARDNER, R. H. Quantitative Methods in Landscape Ecology: the analysis and interpretation of landscape heterogeneity. Springer Verlag: New York, NY. 1991. 536p.

VITTE, A. C. O desenvolvimento do conceito de paisagem e a sua inserção na geografia física.Mercator,v. 6, p.1171-78, 2007

YANG, H.; YANG, X.; HESKEL, M.; SUN, S.; TANG, J. Seasonal variations of leaf and canopy properties tracked by ground-based NDVI imagery in a temperate forest. Nature (Scientific Reports), v. 7, p. 1-10, 2017.

YU, D.; LIU, Y.; XUN, B.; SHAO, H. Measuring Landscape Connectivity in a Urban Area for Biological Conservation. Clean-Soil, Air, Water, v. 43, n. 4, p. 605-613, 2015. 


\title{
A TEORIA DO FORRAGEAMENTO ÓTIMO COMO FERRAMENTA NO ESTUDO DE COMUNIDADES DE PESCADORES ARTESANAIS
}

\author{
Miguel Santana de Almeida Neto ${ }^{36}$ \\ Carolina Alves Collier de Almeida ${ }^{37}$ \\ Gabriela Macedo Aretakis de Almeida ${ }^{38}$ \\ Ana Carla Asfora El-Deir ${ }^{39}$ \\ José da Silva Mourão ${ }^{40}$
}

\section{INTRODUÇÃO}

A pesca artesanal é reconhecida como uma atividade de pescaria de pequena escala que, em geral, é realizada por indivíduos, famílias ou pequenos grupos, e que apresenta menor impacto ambiental e investimento financeiro, quando comparada à pesca industrial (BERKES et al., 2001; CHUENPAGDEE et al., 2006; JACQUET; PAULY, 2008). Estas atividades de exploração pesqueira decorrem de iniciativas locais, envolvendo formas de organização econômica com fins múltiplos, entre os quais a reprodução social e a busca de ganhos monetários (CHABOUD;CHARLES-DOMINIQUE, 1991).

\footnotetext{
${ }^{36}$ Professor do Instituto Federal de Educação, Ciência e Tecnologia do Sertão Pernambucano (IFSERTÃO-PE). DOUTOR em Etnobiologia e Conservação da Natureza pela Universidade Federal Rural de Pernambuco, UFRPE, Brasil. E-mail: miguel.almeida@ifsertao-pe.edu.br.

${ }^{37}$ Professora do Instituto Federal de Educação, Ciência e Tecnologia do Sertão Pernambucano (IFSERTÃO-PE). Doutora em Etnobiologia e Conservação da Natureza pela Universidade Federal Rural de Pernambuco, UFRPE, Brasil. E-mail: carol.collier@ hotmail.com.

${ }^{38}$ Professora do Departamento de Tecnologia e Ciências Sociais (DTCS - Campus Juazeiro) da Universidade do Estado da Bahia (UNEB). Doutora em Desenvolvimento e Meio Ambiente pelo Programa de pós-graduação em Desenvolvimento e Meio Ambiente (PRODEMA) da Universidade Federal de Pernambuco (UFPE). E-mail: gabiaretakis@hotmail.com.

${ }^{39}$ Professora do Departamento de Biologia, Universidade Federal Rural de Pernambuco, UFRPE, Brasil. Professora do Programa de pós graduação em Ecologia, UFRPE, Brasil. E-mail: anacarlaeldeir@gmail.com.

${ }^{40}$ Professor do Departamento de Biologia, Universidade Estadual da Paraíba, UEPB, Brasil. Professor do Programa de pós graduação em Etnobiologia e conservação da natureza, PPGEtno, UFRPE. E-mail: tramataia@gmail.com.
} 
Estima-se que a pesca de pequena escala contribui com mais de 120 milhões de empregos, suportando mais de 500 milhões de pessoas ao redor do mundo (FAO, 2012). No Brasil, a pesca artesanal desempenha importante papel no contexto econômico e sociocultural, correspondendo a aproximadamente $55 \%$ do pescado comercializado no País (MPA/BRASIL,2012). Este tipo de pesca corresponde a uma atividade dinâmica, que sofre alterações em decorrência de diferentes estratégias de gestão, mudanças nas espécies alvo, adaptação às mudanças climáticas, apetrechos de pesca conhecidos, entre outros fatores (AGUILHERA et al., 2015). A compreensão das estratégias de pesca desenvolvidas localmente, bem como o conhecimento das motivações que influenciam os processos de tomada de decisão dos pescadores artesanais, são essenciais para o estabelecimento de medidas de gestão adequadas para evitar a depleção dos estoques pesqueiros e promover a conservação da fauna local, bem como do seu ecossistema (e.g. ASWANI, 1998; LOPES et al., 2011).

Diante da necessidade do desenvolvimento de estratégias para a gestão da pesca, Begossi (2008) destaca a importância da aplicação de novos métodos e abordagens que gerem informações para a construção dessas estratégias. Esta autora ressalta a compreensão do comportamento dos pescadores como um dos aspectos do conhecimento local importantes para a gestão da pesca, sendo essas informações obtidas através de estudos com enfoque ecológico para compreender a dinâmica das atividades pesqueiras. Essas abordagens podem revelar informações como o conhecimento de quais são as espécies alvo, como os pescadores as procuram e capturam, entre outras.

\section{MODELOS DA TEORIA DO FORRAGEAMENTO ÓTIMO APLICADOS A GRUPOS DE PESCADORES ARTESANAIS}

A utilização de modelos e teorias ecológicas tem sido realizada para a compreensão da relação do homem com os recursos naturais desde o início do século XX (BEGOSSI, 1993). $\mathrm{Na}$ segunda metade deste século a chamada ecologia cultural passou a incorporar conceitos da ecologia evolutiva no estudo de grupos humanos (BEGOSSI, 1994). Uma destas teorias decorrentes da ecologia, a Teoria do Forrageamento Ótimo (TFO), admite que as decisões de forrageamento são realizadas no intuito de otimizar os retornos obtidos durante o forrageio, através de comportamentos diversos como a seleção de locais de forrageio mais produtivos, entre outros (STEPHENS; KREBS, 1986). A teoria de forrageio ótimo, como outras teorias 
de ecologia provenientes da ecologia evolutiva, possui profundas raízes na microeconomia (RAPPORT; TURNER,1977). Essa teoria foi desenvolvida por MacArthur e Pianka (1966), e pouco tempo depois foi identificado o seu potencial para a compreensão do comportamento de forrageio em grupos humanos, tendo esta aplicação desde a década de 1980 (e.g. WINTERHALDER, 1981; HAMES; VICKERS, 1982; SMITH, 1983).

Para Smith (1983), a utilização desta teoria em grupos humanos veio auxiliar no preenchimento de lacunas da ecologia cultural, especialmente no que diz respeito às heterogêneas estratégias de forrageamento presentes nas diferentes populações humanas. No entanto, Winterhalder (1981) ressalta que há diferenças no entendimento da TFO em estudos com grupos humanos, levando em consideração que a adaptação do homem às novas condições ambientais não está condicionada à ocorrência de mutações ou predisposição genética, pois os humanos apresentam comportamentos flexíveis, além da capacidade de realizar rapidamente inovações culturais diante de mudanças ambientais. Nesse sentido, a aplicação de modelos e teorias ecológicas em estudo com grupos humanos requer adequações, como a inserção de fatores e variáveis não previstas inicialmente nos modelos ecológicos originais. Uma das adequações nesta teoria para sua aplicação em estudos de ecologia humana é a de incluir outros valores além de calorias, como preço do alimento, quantidade de espinhas em peixes, entre outros (BEGOSSI 2006). Além disso, é importante também considerar diferentes variáveis como o tipo de apetrecho e possíveis interferências das variações ambientais sazonais (ALMEIDA NETO et al., 2018).

Para compreender os modelos da TFO, devem ser consideradas as suposições básicas que correspondem à decisão do forrageador, como: a escolha do local de forrageio e o tempo desta atividade; a moeda de troca que será utilizada para avaliar o retorno e fitness; bem como as restrições que limitam e definem a relação entre a decisão e os retornos (STEPHENS; KREBS, 1986). A partir desses princípios foram desenvolvidos os modelos que compõem a TFO.

Considerando o meio natural como um ambiente heterogêneo, MacArthur e Pianka (1966) propuseram o primeiro modelo da TFO, conhecido como Modelo da Escolha da Mancha, que considera o meio natural como um ambiente heterogêneo formado por diferentes manchas de recursos, admitindo que o forrageador otimiza seu forrageamento selecionando as manchas de recursos que apresentem maior retorno. Sosis (2002) ressalta que, para uma melhor observação e compreensão deste modelo, devem ser consideradas as variações diárias na rentabilidade das manchas de recurso, bem como o modo que esta variação nos locais de 
forrageio afeta a tomada de decisão dos forrageadores. Nessa perspectiva, alguns autores tentaram aplicar o Modelo de Escolha da Mancha no estudo com pescadores artesanais. Nesse sentido, Oliveira e Begossi (2011) observaram que a escolha do local de forrageio estava relacionada com a taxa de retorno obtida no último evento de forrageio, corroborando a premissa deste modelo. Em contrapartida, o estudo realizado por Almeida Neto (2018) evidenciou que as alterações diárias nos retornos obtidos nas diferentes manchas não afetaram a escolha pelos pescadores, indicando que neste caso o Modelo de Escolha da Mancha não se aplicaria devido a fatores sociais, como o Territorialismo presente na comunidade pesqueira local.

Outro modelo foi desenvolvido por Charnov (1976) para tentar compreender qual deveria ser o tempo ótimo de permanência numa mancha de recurso, sendo este modelo chamado de Teorema do Valor Marginal. Segundo este autor, as manchas são constituídas por recursos finitos, e conforme o predador realiza seu forrageamento, a disponibilidade imediata de recursos diminui. Diante disso, Charnov (1976) defende que para um melhor aproveitamento dos recursos, o forrageador deve permanecer na mancha apenas enquanto sua taxa de retorno for superior à taxa de retorno média do ambiente. Em um levantamento realizado por Nonacs (2001) foram avaliados 26 estudos envolvendo a aplicação do Teorema do Valor Marginal para explicar as estratégias de otimização do forrageio de alguns grupos animais. Segundo a pesquisa deste autor, os forrageadores permaneceram nas manchas por mais tempo do que o modelo previa, demonstrando que não houve otimização do forrageamento nestes casos. Em grupos humanos, são escassos os estudos que desenvolvam hipóteses acerca do Teorema do Valor Marginal, o que pode estar relacionado à dificuldade, ou impossibilidade, de medir verdadeiramente as curvas de ganho relacionadas ao retorno (SOSIS, 2002).

No Brasil, Begossi (1992) buscou aplicar o Teorema do Valor Marginal com um grupo de pescadores artesanais em ambiente marinho, e observou que os pescadores geralmente permaneceram mais tempo nas manchas de recursos do que o teorema previa como tempo ótimo. A respeito destes comportamentos conflitantes com as premissas do Teorema do Valor Marginal, Nonacs (2001), ressalta que os modelos são apenas simplificações da realidade e que o maior tempo de permanência pode estar associado a diversos fatores como, por exemplo, o comportamento do predador e seu estado físico. Por outro lado, para grupos humanos, Begossi (1992) atribuiu esse comportamento à dificuldade dos pescadores em 
perceber o esgotamento das manchas, bem como a questões de competitividade entre pescadores que conduzem a um comportamento menos conservador.

O modelo mais empregado atualmente no estudo de grupos humanos, Modelo do Local Central, foi proposto em 1979 por Orians e Pearson para avaliar o comportamento de forrageadores que não consumiam suas presas no local de captura. Este modelo leva em consideração a viagem de ida até o local de forrageio, o período de forrageamento e a viagem de retorno até o local central. Admite-se então que os forrageadores podem compensar os gastos decorrentes da viagem através da sua permanência por um tempo maior em manchas de recurso mais distantes, a fim de retornar uma maior quantidade de energia (ORIANS; PEARSON, 1979). O Modelo do Local Central é considerado muito eficiente para avaliar o comportamento e as estratégias de grupos humanos como os pescadores, levando em consideração que eles retornam para suas residências após a sua atividade de pesca (e. g. BEGOSSI, 1992; BIRD; BLIEGE BIRD, 1997; BEGOSSI et al., 2005; BEGOSSI et al., 2009; OLIVEIRA; BEGOSSI, 2011;LOPES et al., 2011).

O Modelo do Local Central apresenta as premissas de que à medida que aumenta o tempo de viagem, aumentam também o tamanho da captura e o tempo de permanência na mancha (ORIANS; PEARSON, 1979). No intuito de testar essas previsões foram realizados diversos estudos, como o de Oliveira e Begossi (2011) que tiveram seus resultados condizentes com as predições propostas pelo Modelo do Local Central. Entretanto, Lopes et al. (2011), avaliando a pesca em habitats marinhos e dulcícolas, observaram que as predições do modelo explicaram o comportamento dos pescadores artesanais apenas em alguns tipos de habitat e estações do ano. Almeida Neto et al. (2018) testaram este modelo sob diferentes tipos de apetrechos e estações do ano, identificando a importância destes fatores no ajuste das atividades de pesca a este modelo. Além destes autores, outros estudos trouxeram resultados conflitantes, apresentando algumas predições atendidas em detrimento de outras (e. g. BEGOSSI, 1992; BEGOSSI et al., 2005).

\section{A TEORIA DO FORRAGEAMENTO ÓTIMO E A COMPLEXIDADE DOS SISTEMAS HUMANOS}

Os estudos que encontram resultados conflitantes com as premissas dos modelos da TFO em estudos com comunidades de pescadores artesanais ressaltam que, devido à complexidade dos sistemas humanos, surgem diversas variáveis que não fazem parte dos 
modelos (e.g. BEGOSSI et al. 2005; ALMEIDA NETO et al., 2018). No rio Negro, Begossi et al. (2005) justificaram os comportamentos "não ideais", contrários aos princípios de maximização da TFO, considerando como fator limitante a quantidade de gelo disponível para a conservação do pescado, que limitava o tempo de permanência na pesca. Na baía de Sepetiba, Begossi (1992) exemplificou que o acesso aberto aos locais de pesca poderia ocasionar situações de competição entre os pescadores, adicionalmente, as mudanças ambientais são também apontadas como possíveis motivos para comportamentos não otimizadores (LALAND; BROWN, 2002).Lopes et al. (2011) ressaltam que a pesca consiste numa atividade complexa e imprevisível, envolvendo restrições não previstas nos modelos de otimização do forrageio. Apesar dos modelos previstos pela TFO revelarem as estratégias de maior rendimento na extração de recursos, algumas vezes, a adoção de comportamentos "nãoideais" pode ser vantajosa para os pescadores diante das suas necessidades individuais.

Originalmente, os estudos que envolviam a TFO mensuravam o retorno em Kcal ou Biomassa para calcular o fitness decorrente da atividade de forrageio (e. g. MACARTHUR; PIANKA, 1966). Entretanto, em algumas populações humanas, como os pescadores artesanais, a preocupação dos 'forrageadores' não consiste apenas em trazer alimento, mas envolve relações mais complexas de venda do seu produto para comprar bens e outros alimentos (BEGOSSI; RICHERSON, 1992). Em situações como estas outras moedas de troca podem se ajustar melhor às predições dos modelos da TFO, tornando-os mais robustos, conforme argumentaram Begossi e Richerson (1992). Diante do caráter comercial da pesca artesanal, a moeda de troca que melhor tem se ajustado aos modelos é o retorno financeiro, empregado com sucesso por diversos autores (e. g. BEGOSSI; RICHERSON, 1992; ASWANI, 1998; NEHRER; BEGOSSI, 2000; BEGOSSI et al., 2005; OLIVEIRA; BEGOSSI, 2011; ALMEIDA NETO et al. 2018).

A aplicação da teoria do forrageamento ótimo em populações de pescadores artesanais permite prever os tipos e abundância dos peixes utilizados na pesca, intensificação da pesca, frequência de exploração e localização de manchas de recursos, fornecendo informações importantes para a gestão pesqueira (ASWANI, 1998). A compreensão das estratégias de forrageamento dos pescadores locais permite o estabelecimento de medidas de gestão adequadas a cada situação, evitando a depleção dos estoques pesqueiros e promovendo a conservação da fauna local e do ambiente (ASWANI, 1998; LOPES et al., 2011).

Diante do exposto, fica evidente que a TFO representa uma importante ferramenta para estudos acerca das atividades pesqueiras das comunidades de pescadores artesanais, 
sendo necessária a realização de mais estudos no intuito de desenvolver modelos preditivos cada vez mais adequados às diferentes realidades dos diversos grupos humanos.

\section{REFERÊNCIAS}

AGUILERA, S. E.; COLE, J.; FINKBEINER, E. M.; LE CORNU, E.; BAN, N. C.; CARR, M. H.; CINNER, J. E.; CROWDER, L. B.; GELCICH, S.; HICKS, C. C.; KITTINGER, J. N.; MARTONE, R.; MALONE, D.: POMEROY, C.; STARR, R. M.; SERAM, S.; ZUERCHER, R.; BROAD, K. Managing Small-Scale Commercial Fisheries for Adaptive Capacity: Insights from Dynamic Social-Ecological Drivers of Change in Monterey Bay. PLoS ONE 10(3). 2015.

ALMEIDA NETO, M. S.;ALMEIDA, C. A. C.;ROSA FILHO, J. S.;El-Deir, A. C. A.;SILVA MOURÃO, J. ForagingStrategiesofArtisanalFishers in a BrazilianReservoir. Humanecology, 46(4), 561-571. 2018.

ALMEIDA NETO, M. S. Decisão e otimização na pesca artesanal em um reservatóriono Nordeste do Brasil. Tese de Doutorado, PGETNO- Universdade Federal Rural de Pernambuco, Recife, 2018. 97 f.

ASWANI, S. The use of optimal foraging theory to assess the fishing strategies of Pacific Island artisanal fishers: A methodological review. Traditional Marine Resource Management andKnowledge Inf. Bulletin 9: 21-26.1998.

BEGOSSI, A. The use of optimal foraging theory to understand fishing strategies: a case from Sepetiba Bay (State of Rio de Janeiro, Brazil). HumanEcology , 20 (4): 463-475. 1992.

BEGOSSI, A. Ecologia Humana: um enfoque das relações homem-ambiente. Interciência 18(3): 121-132, 1993.

BEGOSSI, A. The application of ecological theory to human behavior: niche, diversity and optimal foraging. The Seventh International Conference of the Society for Human Ecology, Michigan State University, April 21-24, p. 2-18. 1994.

BEGOSSI, A. Métodos e análises em ecologia de pescadores. In: Garay I. E. G. andBecker B. $\mathrm{K}$. As dimensões humanas da biodiversidade - o desafio de novasrelações sociedadenatureza no século XXI. Petrópolis: Vozes. 2006.

BEGOSSI A. Local knowledge and training towards management.Environ. Develop.Sustain. 10:591-603, 2008.

BEGOSSI, A.;RICHERSON, P.J. The animal diet of families from Buzios Island (Brazil): An optimal foraging approach. Journal of Human Ecology 3(2): 433-445. 1992.

BEGOSSI, A.; SILVANO, R. A. M.; RAMOS, R. M. Foraging behavior among fishermen from the Negro and Piracicaba rivers, Brazil: implications for management. In River Basin Management III.The WIT Press, Southhampton, UK. pp. 503-513. 2005. 
BEGOSSI, A. ; CLAUZET, M. ; HANAZAKI, N. ; LOPES, P. F.; RAMIRES, M.;

SILVANO, R. A. M. Fisher's decision making, optimal foraging and management. III Seminário de Gestão Socioambiental para o Desenvolvimento Sustentável da Aquiicultura e da Pesca no Brasil - Proceedings in CD ROM. 2009.

BERKES, F.; COLDING, J.; FOLKE, C. Rediscovery of traditional ecological knowledge as adaptive management. Ecological Applications, v. 10, p. 1251-1262, 2000.

BERKES, F.; MAHON, R.; MCCONNEY, P.; POLLNAC, R.; POMEROY, R. (authors of the English version). KALIKOSKI, D.C. (Org. Portugueseversion). Gestão da pesca de pequena escala: diretrizes e métodos alternativos, Ed. Furg (Brasil) \& IDRC (Canada), Rio Grande, 360 p. 2006.

BIRD, D. W.; BLIEGE BIRD, R. L. Contemporary shellfish gathering strategies among the Merriam of the Torres Strait Islands, Australia: testing predictions of a Central Place Foraging Model. Journal of Archaeological Science 24: 39-63. 1997.

CHARNOV, E. L. Optimal foraging: the marginal value theorem.

TheoreticalPopulationBiology9: 129-136. 1976.

CHABOUD, C.;CHARLES-DOMINIQUE, E.Les pêchesartisanalesen Afrique de l'Ouest: étatdesconnaissances et évolution de la recherche. In Durand, J. R., Lemoalle J., \& Weber J. (Eds). La Recherche Face à la PêcheArtisanale.Paris: ORSTOM. 99-141. 1991.

CHUENPAGDEE, R.;LIGUORI, L.;PALOMARES, M. L. D.;PAULY, D.Bottom-up, global estimates of small-scale marine fisheries catches. Vancouver: Fisheries Centre - University of British Columbia, 14(8), 1-110. 2006. http://dx.doi.org/10.14288/1.0074761.

Food and Agriculture Organization (FAO). (2012). Report of the FAO workshop on international guidelines for securing sustainable small-scale fisheries. Rome: FAO. Report No.: 1004.

HAMES, R. B.; VICKERS, W. T. Optimal foraging theory as a model to explain variability in amazonianhunting.American Ethnologist 9(2):358-378. 1982.

JACQUET, J.;PAULY, D. Funding priorities: big barriers to small-scale fisheries.

Conservation Biology, 22:832-835. 2008.

LALAND, K. N.; BROWN, G. R. Sense and nonsense: Evolutionary perspectives on human behaviour. New York: Oxford University Press. 2002.

LOPES, P. F.; CLAUZET, M.; HANAZAKI, N.; RAMIRES, M.; SILVANO, R. A.; BEGOSSI, A. Foraging behaviour of Brazilian riverine and coastal fishers: How much is explained by the optimal foraging theory?.Conservat Soc. 9:236-46. 2011.

MACARTHUR, R. H.; PIANKA, E. R.On optimal use of a patchy environment.American Naturalist.100: 603-609. 1966.

MPA/BRASIL. Boletim Estatístico da Pesca e Aquicultura, Brasil 2011. Brasília: Ministério da Pesca e Aquicultura. 2012. 
NEHRER, R.; BEGOSSI, A. Fishingat Copacabana, Rio de Janeiro: local strategies in a global city. Ciência e Cultura 52(1): 26-30. 2000.

NONACS, P. State dependent behavior and the marginal value theorem.Behavioral Ecology 12(1):71-83. 2001.

OLIVEIRA, L. E. C.; BEGOSSI, A..Last Trip Return Rate Influence Patch Choice Decisionsof Small-Scale Shrimp Trawlers: Optimal Foragingin São Francisco, Coastal Brazil. Hum Ecol 39:323-332. 2011.

ORIANS, G. H.; PEARSON, N. E On the theory of central place foraging. In: Horn, D.J., Mitchell, R.D., Stairs, G.R. (Eds.), Analysis of Ecological Systems. The Ohio StateUniversity Press, Columbus, pp. 154-177. 1979.

RAPPORT, D. J.; TURNER, J. E. Economic models in ecology. Science, v. 195, p. 367 373. 1997.

SMITH, E. A. Anthropological applications of optimal foraging theory: a critical review. Current Anthropology, 24:625-651. 1983.

SOSIS, R. Patch choice decisions among Ifaluk Fishers. American Anthropologist 104(2): 583-598. 2002.

STEPHENS, D. W.; KREBS, J. R. Foraging Theory. Princeton University Press, Princeton. 1986. $247 \mathrm{p}$.

WINTERHALDER, B. Optimal foraging strategies and hunter-gatherer research in anthropology: Theory and models. In: Hunter-gatherer foraging strategies: Ethnographic and archaeological analyses (eds. Winterhalder, B. and E.A. Smith). Pp. 13-15. Chicago: The University of Chicago Press.1981. 


\title{
HOMENS OU MULHERES NA PESCA: NOVOS PARADIGMAS DA MARISCAGEM NO NORDESTE DO BRASIL
}

\author{
Ivo Raposo Gonçalves Cidreira-Neto ${ }^{41}$ \\ Gilberto Gonçalves Rodrigues ${ }^{42}$
}

\section{INTRODUÇÃO}

Os termos povos indígenas, comunidades tradicionais e populações locais não são fáceis e simples de se explicar, devido à complexidade e heterogeneidade dos grupos que os compõem (PEREIRA; DIEGES, 2010), mesmo que alguns já se reconheçam quanto sua identidade. Diegues (2000, p.22) caracteriza como "grupos humanos culturalmente diferenciados que historicamente reproduzem seu modo de vida, de forma mais ou menos isolada, com base em modos de cooperação social e formas específicas de relações com a natureza”. Em nível nacional, o Decreto n 6.040, de 7 de fevereiro de 2007, institui a Política Nacional de Desenvolvimento Sustentável dos Povos e Comunidades Tradicionais, que define comunidade tradicional como:

Grupos culturalmente diferenciados e que se reconhecem como tais, que possuem formas próprias de organização social, que ocupam e usam territórios e recursos naturais como condição para sua reprodução cultural, social, religiosa, ancestral e econômica, utilizando conhecimentos, inovações e práticas gerados e transmitidos pela tradição.

As práticas tradicionais são associadas ao modelo econômico antagônico ao capitalismo (DIEGUES, 2000), apresentando relações de trabalho ligadas a natureza. São exemplos de comunidades tradicionais os caiçaras, pescadores/as artesanais, quilombolas e indígenas, sendo consideradas por apresentar padrões pré-capitalistas, não associando o

\footnotetext{
${ }^{41}$ Doutorando em Desenvolvimento e Meio Ambiente pela Universidade Federal de Pernambuco (PRODEMA UFPE). E-mail: ivo.raposo@hotmail.com.

42 Professor do Departamento de Zoologia da Universidade Federal de Pernambuco. E-mail: gilberto.rodrigues@ufpe.br.
} 
trabalho ao lucro (DIEGUES, 2000), acrescentando-se mais recentemente agricultores extrativistas (BALDAUF; HANAZAKI; REIS, 2007), pequenos agricultores rurais, marisqueiras, catadoras e catadores de siri e caranguejos (RODRIGUES et al., 2017). Diante disto, procuramos aqui elencar alguns atributos da importância da atividade de catação de mariscos e outros moluscos bivalves no Rio Paraíba do Norte, principalmente, a partir do Município de Bayeux, na Paraíba, onde a mariscagem se faz mais presente, como forma de subsistência e comercialização destes recursos naturais.

\section{PESCA ARTESANAL E O CONHECIMENTO ECOLÓGICO LOCAL}

A pesca artesanal compreende uma diversidade de artes de coleta de recursos faunísticos presentes nas comunidades locais, sendo que no Brasil é estimado que existem cerca de duas milhões de pessoas envolvidas nessa atividade de pesca (VASCONCELLOS; DIEGUES; SALES, 2007). Os pescadores/as artesanais são conhecidos por realizar a pesca em escala local, sozinho ou em núcleo familiar e/ou não assalariada (CLAUZET; RAMIRES; BARRELLA, 2005), utilizando apetrechos comumente fabricados pelo próprio pescador/a. Diegues (1999) aponta que o surgimento de diversas culturas a partir da prática da pesca artesanal, como a dos Jangadeiros no Nordeste, os Caiçaras entre o Rio de Janeiro e São Paulo e os Açorianos em Santa Catarina e Rio Grande do Sul. No Nordeste a mariscagem tem seu início como forma de subsistência e comercialização - o que chamamos de economia solidária, após o período escravocrata.

A prática da catação do marisco, conhecida como mariscagem (OLIVEIRA; ELDEIR, 2013) ou trabalho na maré, representa uma forma de pesca tradicional, sendo realizada comumente por núcleos sociais e/ou familiares, extraindo o marisco manualmente ou com apetrechos, devido sua simplicidade de pesca. As marisqueiras apresentam amplo conhecimento ecológicos e ambiental sobre os fatores bióticos e abióticos que influenciam diretamente nos estuários, como variação de salinidade, $\mathrm{pH}$, temperatura, biologia e ecologia das populações de marisco (NISHIDA; NORDI; ALVES, 2004) e mais recentemente sobre os impactos ocorridos na diminuição do tamanho médio das populações do marisco-pedra (CIDREIRA-NETO et al., 2018)

A tradicionalidade pode ser apresentada como um modelo de produção "précapitalista", ameaçada principalmente a partir da Revolução Industrial com a injeção do 
capital como forma de desenvolvimento, quebrando a produção artesanal, vista como antiquada. Oliveira e Silva (2012, p/330) apontam que:

\begin{abstract}
A abordagem da pesca artesanal pelo Estado brasileiro demonstra a continuidade nos intuitos de industrialização. Nesse sentido, o Estado, sob a égide de governos ditatoriais ou democráticos, continua, além de intervindo nos setores produtivos, estimulando um modo de produção e de vida específico e urbano. Ocorre o consequente desaparecimento de um modo de vida tradicional, fundado em bases produtivas comunitárias.
\end{abstract}

Essa afirmação reforça a forma como o modelo capitalista adentra nas formas de trabalho artesanais, demonstrando a necessidade de aplicação de metodologias que busquem um resgate das atividades artesanais, bem como o empoderamento destas populações locais sobre o direito de manutenção e conservação dos seus territórios. A etnoecologia surge como ciência para compreender a relação entre o homem e o meio ambiente, contemplando o Conhecimento Ecológico Local (CEL) (BERKES, 1999; TOLEDO; BARRERA-BASSOLS, 2008) como base para a gestão e desenvolvimento de políticas ambientais.

O CEL pode ser definido como o conjunto de saberes, práticas e crenças, que são transmitidos através da oralidade nas relações sociais nas comunidades, aonde a forma de entendimento e utilização do meio ambiente vai sendo adaptado e transmitido (BERKES, 1999). Toledo e Barrera-Bassols (2008) apresentam o complexo K-C-P (Kosmos-CorpusPráxis) como ferramenta de compreensão das atividades exercidas pelo homem em relação a natureza.

\title{
3 O MUNICÍPIO DE BAYEUX E A MARISCAGEM
}

Bayeux é um município do Estado da Paraíba, localizada no Nordeste do Brasil, com uma área total de $27,536 \mathrm{~km}^{2}$ e uma população de aproximadamente cem mil habitantes. A comunidade é divindade entre trabalhadores que vão para João Pessoa, realizando migrações pendulares todos os dias, e pescadores artesanais que utilizam o estuário do rio Paraíba do Norte (Figura 1) para a pesca de mariscos (Anomalocardia flexuosa, LINNAEUS, 1767), unha de velho (Tagelus plebeius, LIGHTFOOT, 1786), sururu (Mytella guyanensis, LAMARCK, 1819) e ostras (Crassostrea rhizophorae, GUILDING, 1828), além caranguejos (Ucides cordatus, LINNAEUS, 1763) e outros crustáceos (MARCELINO et al., 2005). A pesca artesanal é realizada por comunidades ribeirinhas que compõe, principalmente, uma atividade de subsistência, agregando conhecimento empírico acerca das condições ambientais 
(MOURÃO; NORDI, 2003). Nestas atividades são garantidos o sustento de famílias ao longo de gerações e gerações.

Figura 1 A - Vista do manguezal pelo município de Bayeux, Paraíba. Figura 1B - Embarcações utilizadas para a locomoção até as croas de coleta do marisco.

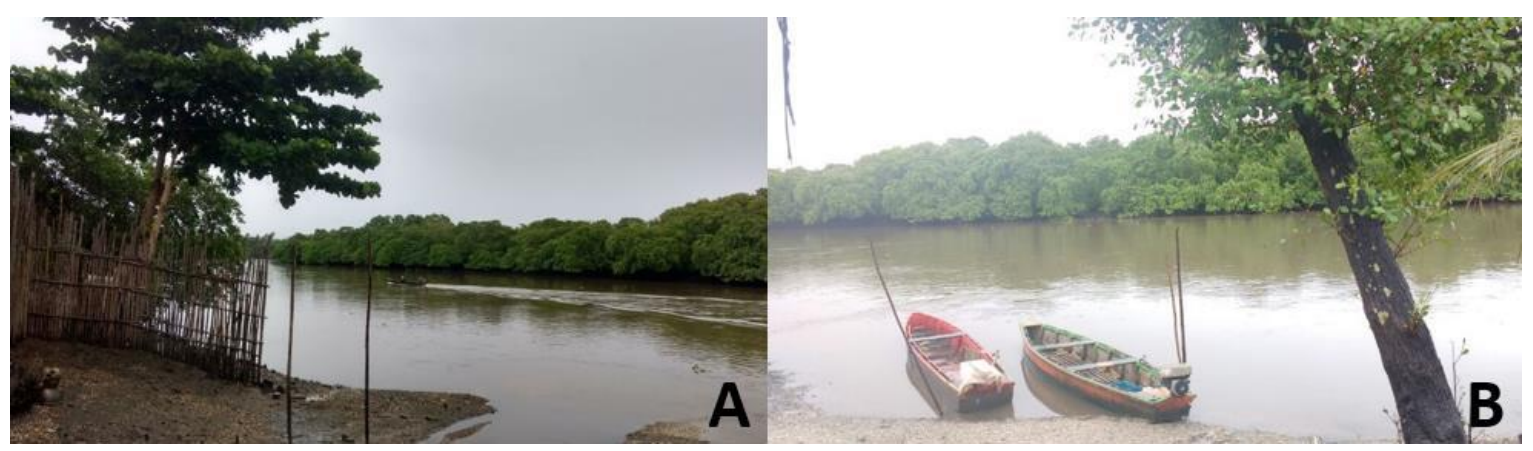

Fonte: Ivo Raposo, 2017.

A catação de moluscos e crustáceos apresenta grande importância para a comunidade, garantindo renda e continuidade da atividade artesanal. O processo de pesca e manejo do marisco, em especial, condiz desde a escolha da croa de coleta (banco areno-lodos) e beneficiamento, até a venda do produto, que pode ser por atravessadores ou para compradores fixos e/ou em feiras locais (DIAS; ROSA; DAMASCENO, 2007), aumentando a rede de trocas e vendas para os moradores locais.

As marisqueiras vão para as croas, onde é realizada a extração do marisco, com pequenas embarcações próprios ou alugadas, variando a frequência de idas, sendo o mais comum a ida de 5 a 7 dias na semana, dependendo do horário da maré baixa, chuvas, entre outros fatores ambientais.

Os mariscos são coletados principalmente com o auxilio do puçá e gadanho (Figura 2A e 2B), apetrechos que segundo as marisqueiras já são utilizados acerca de mais de 20 anos na comunidade, onde a maior parte dos catadores de mariscos utilizam esses instrumentos para o aumento da produtividade. Em Bayeux, em especial, atualmente a pesca manual não é comumente realizada, porém esta possibilita a exclusão dos mariscos que apresentam um tamanho pequeno ( $<15 \mathrm{~mm}$ ) para que seja possível completar seu desenvolvimento e atingir a maturação sexual. Silveira et al. (2013) apontam que o descarte de juvenis pode ser devido mensuração do baixo rendimento da carne e/ou divido a uma atitude de base conservacionista, permitindo que esses juvenis possam reproduzir. 
Figura 2 - Instrumentos utilizados na coleta do marisco. A - Gadanho. B - Puçá.

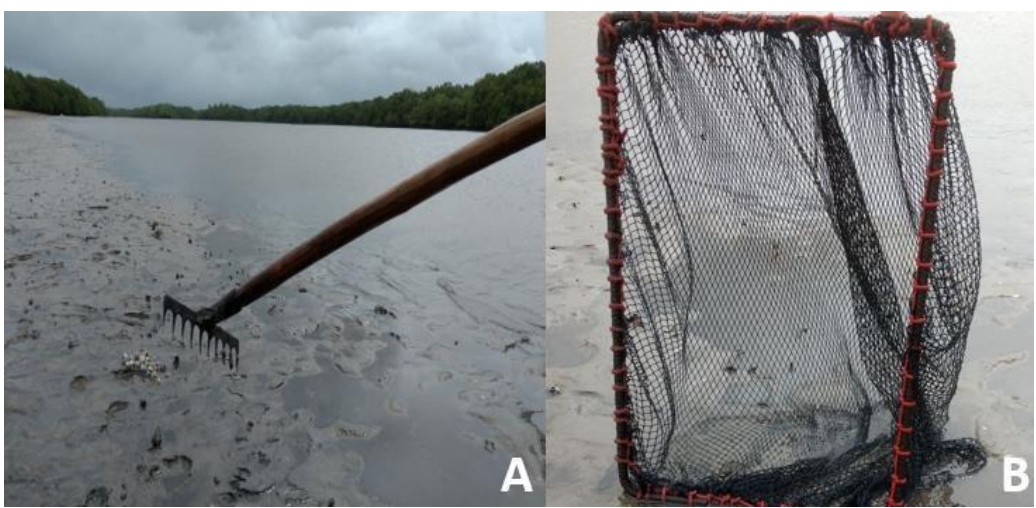

Fonte: Ivo Raposo, 2017.

Com a utilização do puçá e gadanho, que coleta todos os tamanhos do marisco, a separação pode ocorrer ainda na croa, onde no momento em que o marisco vai ser lavado, ocorre a separação prévia. Outras marisqueiras preferem levar os mariscos e separar já nos locais de beneficiamento, que fica a margem do rio, que do ponto de vista conservacionista não é tão efetivo, visto que esses locais apresentam forte antropização. Essa prática de coletar os mariscos realizando a separação nos postos de beneficiamento é uma prática adotada pelos jovens marisqueiros, segundo relato, que não atentam para a necessidade de permanência dos menores no ambiente. Outro problema que resulta na diminuição das populações de marisco é o período chuvoso, que segundo as marisqueiras, a chuva diminui a salinidade do estuário, causando a morte dos bivalves. Estes aspectos corroboram para o CEL que associa a atividade de mariscagem com boas práticas devido a percepção do ambiente, segundo o conhecimento repassado por gerações anteriores e/ou o conhecimento adquirido através da prática.

Sem dúvidas, a problemática expostas por elas, de que a poluição hídrica influencia no tamanho médio do marisco, ou diminuição das populações destes, bem como a escassez de outros recursos, como a unha de veio, ostras e sururus é fato e não refutável pelos estudos realizados. Sobre a qualidade do marisco proveniente da região, Nascimento et al. (2018) constataram que as croas mais distantes dos centros urbanos (próximas aos efluentes do Rio Sanhoá: croa do Cidade e do Portinho) o tamanho médio do marisco-pedra aumenta, assim como em relação da diversidade de bactérias e fungos não patógenos (microbiota endógena).

A partir da crise político-econômica instalada no Brasil, principalmente a partir de 2016, pesca do marisco em Bayeux é principalmente compostas por homes, quebrando a divisão de gêneros, que está atrelada na pesca artesanal, onde o homem pesca em alto mar, enquanto a mulher cuida dos trabalhos domésticos e realiza a pesca nas margens dos rios, estuários e praias (FREITAS et al., 2012; PENA; MATINS; REGO, 2013). Porém, a presença 
masculina na mariscagem no Rio Paraíba do Norte, resultou na intensificação da comercialização do produto (pensamento urbano-capitalista), influenciando na preferência pela utilização de apetrechos de pesca que não possibilita na separação dos tamanhos menores do marisco, ocasionando na redução das populações. Santana (2014, p.91) retrata a divisão de gênero existente na pesca artesanal como:

Essa divisão sexual de trabalho na pesca é por diversas vezes vista como uma naturalização das relações de trabalho homem-mulher, pois cabe aos homens a realização de tarefas mais difíceis e braçais, que necessitem de mais força e à mulher, tradicionalmente, deve realizar as tarefas de casa e a função de cuidar dos filhos. Desse modo se a mulher trabalha fora de casa, é importante que esteja em um ambiente mais seguro e até próximo de sua residência, lembrando que há o acúmulo com as funções domésticas.

Foi sem dúvida a partir da crise econômica, que os homens que trabalhavam em comércios e indústrias locais, ou da capital João Pessoa, retornam para a pesca, assumindo o papel de marisqueiros, para complementar a renda da família. Nesse momento, tem-se a quebra do preconceito quanto a atividade de catação de marisco, que antes era vista como inferior ao trabalho da pesca artesanal realizada pelos homens. O trabalho na maré, trazendo principalmente como exemplo a mariscagem, é uma atividade de menor prestígio, sendo de domínio das mulheres pescadoras (FIGUEIREDO, 2013), mas que em Bayeux essa "realidade" começa a passar por mudanças significativas. A quebra da divisão sexual possibilita a incorporação de novos paradigmas igualitário entre homens e mulheres, tornando a pesca artesanal um ambiente onde nenhuma das partes são sobrecarregadas com o trabalho.

Mesmo com a crescente participação masculina, a mulher marisqueira ainda é a que detém o conhecimento local das práticas e do saber ambiental, sendo elas que comandam os processos da pesca do marisco. Dessa forma, existe um empoderamento feminino, sendo as mestras da maré, que dominam a arte pesqueira. Nos primórdios da pesca artesanal a mulher adentra nesse universo para auxiliar a pesca masculina, apresentando papel coadjuvante. Já devido ao atual cenário político econômico que atinge o Brasil, a chegada dos homens na pesca do marisco pode ser vista como um processo inverso, onde a mulher passa a ser a detentora do saber e o homem coadjuvante.

Por fim, percebe-se que o município de Bayeux passa por novos paradigmas na arte pesqueiras da mariscagem, adequando as novas estruturas e paradigmas através dos processos socioambientais e econômicos. A (re)afirmação da mulher marisqueira vem da necessidade através de um histórico de marginalização, principalmente pela categoria da pesca a qual participam. 


\section{CONSIDERAÇÕES FINAIS}

O estuário do Rio Paraíba do Norte representa uma das fontes de renda base para o município de Bayeux, no qual a pesca artesanal de bivalves agrega valores econômicos, sociais e ambientais. A extração do marisco representa fonte de renda de diversas famílias pescadoras, que retiram seu sustento das croas e lamas do estuário, promovendo interações sociais nos diversos núcleos da pesca (familiares, entre outros), ressaltado a importância da oralidade na transmissão do conhecimento empírico.

A presença do homem na atividade de mariscagem resulta na quebra do paradigma da atividade tradicional sustentável, necessitando de ações estaduais para garantir a gestão deste recurso, evitando assim o processo de sobre exploração em determinadas áreas.

\section{REFERÊNCIAS}

BALDAUF, C.; HANAZAKI, N.; REIS, M. S. Caracterização etnobotânica dos sistemas de manejo de samambaia-preta (Rumohra adiantiformis (G. Forst) Ching-Dryopteridaceae) utilizados no sul do Brasil. Acta Botanica Brasilica, v. 21, n. 4, p. 823-834, 2007.

BERKES, F. Sacred ecology: traditional ecological knowledge and resource managemeent Filadélfia. Taylor \& Francis, 1999.

BRASIL. Decreto $\mathbf{N}^{\mathbf{0}} \mathbf{6 . 0 4 0}$, de 7 de fevereiro de 2007. Institui a Política Nacional de Desenvolvimento Sustentável dos Povos e Comunidades Tradicionais. Disponível em: < http://www.planalto.gov.br/ccivil_03/_ato2007-2010/2007/decreto/d6040.htm>. Acesso em: 10 set. de 2018.

CIDREIRA-NETO, I. R. G.; NASCIMENTO, D. M.; MORAES, P. X.; RODRIGUES, G. G. Análise biométrica de Anomalocardia flexuosa em Área de Proteção Ambiental. Journal Evironmental Analysis and Progress, v.3, n.2, p.191-199, 2018.

CLAUZET, M.; RAMIRES, M.; BARRELLA, W. Pesca artesanal e conhecimento local de duas populações caiçaras (Enseada do Mar Virado e Barra do Uma) no litoral de São Paulo, Brasil. Multiciência: a linguagem da ciência, v.4, 2005.

DIAS, T. L. P.; ROSA, R. S.; DAMASCENO, L. C. P. Aspectos socioeconômicos, percepção ambiental e perspectivas das mulheres marisqueiras da Reserva de Desenvolvimento Sustentável Ponta do Tubarão (Rio Grande do Norte, Brasil). Gaia Scientia, v.1, n.1, p.25-35, 2007. 
DIEGUES, A. C. S. A sócio-antropologia das comunidades de pescadores marítimos no Brasil. Etnográfica, 1999.

DIEGUES, A. C. (org.). Biodiversidade e comunidades tradicionais no Brasil. São Paulo: NUPAUB-USP-PROBIO-MMA, 2000.

FIGUEIREDO, M. M. A participação da mulher na organização socioespacial das comunidades pesqueiras: um estudo de caso na Reserva Extrativista Baía do Iguape - BA. Revista Latino-americana de Geografia e Gênero, v.4, n.2, p.77-85, 2013.

FREITAS, S. T.; PAMPLIN, P. A. Z.; LEGAT, J.; FOGAÇA, F. H. S.; BARROS, R. M. Conhecimento tradicional das marisqueiras da Barra Grande, Área de Proteção Ambiental do Delta do Rio Paraíba, Piauí, Brasil. Ambiente e Sociedade, v.15, n.2, p.91-112, 2012.

MARCELINO, R.L.; SASSI, R.; CORDEIRO, T.A.; COSTA, C.F. Uma abordagem sócioeconômica e sócio-ambiental dos pescadores artesanais e outros usuários ribeirinhos do estuário do rio Paraíba do Norte, Estado da Paraíba, Brasil. Tropical Oceanography, v.33, n.2, p.183-197, 2005.

MOURÃO, J. S.; NORDI, N. Etnoictologia de pescadores artesanais do estuário do Rio Mamanguape, Paraíba, Brasil. Boletim do Instituto de Pesca, v.29, n.1, p.9-17, 2003.

NASCIMENTO, C. H. V.; CIDREIRA-NETO, I. R. G.; SILVA, R. P.; ASSIS, J. E.; GUSMÃO, N. B.; RODRIGUES, G. G. Caracterização morfométrica e microbiota endógena de populações do marisco Anomalocardia flexuosa Linnaeus, 1767 (Bivalvia: Veneridae). Journal of Environmental Analysis and Progress, v.3, n.3, p.275-286, 2018.

NISHIDA, A. K.; NORDI, N.; ALVES, R. R. N. Abordagem etnoecológica da coleta de moluscos no litoral paraibano. Tropical Oceanography, v.32, n.1, p.53-68, 2004.

OLIVEIRA, O. M. B. A.; SILVA, V. L. O processo de industrialização do setor pesqueiro e a desestruturação da pesca artesanal no Brasil a partir do Código de Pesca de 1967. Sequência, n.65, p.329-357, 2012.

OLIVEIRA, B. M. C.; EL-DEIR, S. G. Mariscagem: um desafio para o litoral norte de Pernambuco. Recife: EDUFRPE, 2013.

PENA, P. G. L.; MARTINS, V.; REGO, R. F. Por uma política para a saúde do trabalhador não assalariado: o caso dos pescadores artesanais e das marisqueiras. Revista Brasileira de Saúde Ocupacional, v.38, n.127, p.57-68, 2013.

PEREIRA, B. E.; DIEGUES, A. C. Conhecimento de populações tradicionais como possibilidade de conservação da natureza: uma reflexão sobre a perspectiva da etnoconservação. Revista de Desenvolvimento e Meio Ambiente, n.22, p.37-50, 2010. 
RODRIGUES, G. G.; SOUZA, A. E. V. N.; LIMA, M. E. A.; CIDREIRA-NETO, I. R. G.; LEITE, J. K. S.; NASCIMENTO, D. M.; HARDER, E.; FREITAS, A. E. C. Território, paisagens e identidades culturais em uma Reserva Extrativista Marinha do Nordeste Brasileiro. Revista de Movimentos Sociais e Dinâmicas Espaciais, v.6, n.1, p.235-242, 2017.

SANTANA, C. G. As percepções ambientais de pescadores e marisqueiras acerca da divisão sexual de trabalho na pesca em Pirambu/SE. Revista Ambivalências, v. 2, n. 3, p. 86-105, 2014.

SILVEIRA, P. C. B.; MESQUITA, B.; MELO, L.; OLIVEIRA-FILHO, I. Estuário, paisagem-fluxo de pescadores artesanais. Iluminuras, v.14, n.34, p.304-323, 2013.

TOLEDO, V; BARRERA-BASSOLS, N. La memoria biocultural: la importância ecológica de las sabidurías tradicionales. Icaria editorial, 2008.

VASCONCELlOS, M.; DIEGUES, A. A.; SALES, R. R. Alguns aspectos relevantes relacionados à pesca artesanal costeira nacional. Brasília: SEAP/PR-Pnud, 2007. 


\title{
ENTRE A RELAÇÃO SOCIEDADE E NATUREZA E O DIREITO SOCIOAMBIENTAL: HÁ LUGAR PARA AS COMUNIDADES TRADICIONAIS DO OESTE BAIANO?
}

\author{
Flávio Marcelo Rodrigues Bruno ${ }^{43}$ \\ Rubio José Ferreira ${ }^{44}$ \\ Andyara Andreza Marques Morais ${ }^{45}$
}

\section{INTRODUÇÃO}

Este trabalho resulta de reflexões que surgem no âmbito de uma pesquisa realizada na Universidade Federal do Oeste da Bahia (UFOB). Considera as confluências transdisciplinares da relação sociedade e natureza e o direito socioambiental, sobretudo no que tange aos saberes das comunidades tradicionais do Oeste Baiano.

A Convenção para a Salvaguarda do Patrimônio Cultural Imaterial, fruto da Conferência Geral das Nações Unidas para a Educação, a Ciência e a Cultura (UNESCO), realizada em Paris (2003) estabelece que o patrimônio cultural imaterial se manifesta através das tradições e expressões orais, incluindo o idioma, das expressões artísticas, das práticas sociais, rituais e atos festivos, dos conhecimentos e práticas relacionados à natureza e ao universo e de técnicas artesanais tradicionais.

Por sua vez, a Convenção sobre a Proteção e Promoção da Diversidade das Expressões Culturais, fruto da Conferência Geral da UNESCO, celebrada em Paris (2005), reconhece a importância dos conhecimentos tradicionais como fonte de riqueza material e imaterial, e, em

\footnotetext{
$\overline{43}$ Docente do Curso de Bacharelado em Direito, no Programa de Pós-Graduação em Gestão da Inovação Tecnológica e Social - Pós-GITS e no Programa de Pós-Graduação em Ciências Humanas e Sociais - PPGCHS da Universidade Federal do Oeste da Bahia, UFOB, Brasil. E-mail: flavio.bruno@msn.com.

${ }^{44}$ Doutor em Geografia pela Universidade Federal de Pernambuco (UFPE), na área de regionalização e análise regional. Professor na Universidade Federal do Oeste da Bahia (UFOB) - Centro das Humanidades.

45 Técnica em Meio ambiente pelo Instituto Federal de Educação, Ciência e Tecnologia da Bahia (IFBA). Acadêmica do curso de Bacharelado em Direito pela Universidade Federal do Oeste da Bahia (UFOB).
} 
particular, dos sistemas de conhecimento das populações indígenas, e sua contribuição positiva para o desenvolvimento sustentável, assim como, a necessidade de assegurar sua adequada proteção e promoção.

As comunidades tradicionais comportam uma gama de conhecimentos e comportamentos, bem como saberes que emergem de etnicidades ou culturas com conhecimentos tradicionais. Os conhecimentos tradicionais, por sua vez, compõem um conjunto de informações, modos de fazer, criar e saber, que são transmitidos oralmente entre os membros de determinado grupo transcendendo gerações e que representam não somente o trabalho destas comunidades, mas se constituem em parte da cultura, suas práticas e costumes. Essas práticas se reproduzem por meio de seus saberes e tradições que encontram conceituações diversas na legislação nacional e internacional, haja vista a sua intrínseca relação com a biodiversidade que de modo transversal interfere na definição de políticas de proteção e gestão do meio-ambiente. E é a partir destas concepções iniciais que o presente ensaio pretende apontar algumas das dimensões das comunidades tradicionais que produzem os saberes culturais no Oeste da Bahia.

Não se pretende o esgotamento das inquietações sobre o tema, mas sim, contribuir para o debate que estabelece condições de possibilidades de sua ampliação. É necessário compreender os povos e suas culturas, o envolvimento socioambiental, as perspectivas jurídicas, agroecológicas e as inúmeras dimensões se estão no entorno do próprio desenvolvimento do direito das comunidades tradicionais desta região.

O texto se apresenta inicialmente tratando da relação da sociedade com a natureza. Em seguida, traz a contextualização e a abordagem constitucional sobre o socioambientalismo, abrindo o diálogo sobre o Direito Socioambiental e o Direito das Sociedades Tradicionais. Por fim, os aspectos das comunidades tradicionais no Oeste Baiano são apresentados.

\section{REFLEXÕES SOBRE A RELAÇÃO DA SOCIEDADE COM A NATUREZA}

A natureza é do homem. Este foi o pensamento que predominou na relação entre a sociedade e a natureza durante muito tempo. O homem se situa como o ser soberano que pode dispor da natureza ou do meio ambiente como bem quiser. Aliás, quando o homem percebe que pode modificar a natureza e adaptá-la às suas necessidades, passa a construir um mundo cultural só seu, o qual está acima do meio ambiente. Isso é tão evidente, que Gonçalves (2014) aponta que o próprio conceito de natureza não é natural. Resulta, assim, de formação 
cultural. Isto, claro, permeado de tensões quando se percebe que a relação entre o homem e o meio ambiente perpassa por impactos da ação humana sobre a natureza (BERDOULAY, 2012). A formação do mundo cultural se dá quando o homem utiliza aquilo que lhe é dado como base, ou seja, a natureza de forma crua e passa a modificá-la e adaptá-la para atender suas necessidades, formando um mundo construído. A cultura é o conjunto de tudo aquilo que, nos planos material e espiritual, o homem constrói sobre a base da natureza, quer para modificá-la, quer para modificar-se a si mesmo. Desta feita, o homem é o centro da análise da cultura. (CLAVAL, 2006)

Explica Toynbee (1979), que o homem é coetâneo dos demais sobreviventes de seres vivos porque são espécies relacionadas entre si, como os ramos de uma árvore que derivam de uma mesma raiz comum, mas que passam a se diferenciar no processo de evolução. Ocorre que, o fator determinante para o aparecimento da natureza humana na biosfera não é nem o desenvolvimento de uma característica anatômica, nem a aquisição de uma habilidade; o acontecimento histórico, é o despertar do homem para a percepção consciente.

Deduz-se que a percepção consciente é determinante para a formação de um comportamento ético do homem, antes não existente. Fato esse, que modifica toda a sua forma de existência. Junto com a percepção consciente vem a distinção do homem dos demais seres vivos, que é o plano da ética e, nesse plano, “a característica mais conspícua e enigmática da natureza humana é a extensão da gama ética do homem” (TOYNBEE, 1979, p.45), ou seja, passa o homem a deter uma característica que somente a si é peculiar: a característica consciente do bem e do mal.

Desde a sua trajetória na Terra, pós-fase pré-humana, o homem veio conquistando tudo aquilo que faz parte da biosfera e se tornou o seu senhor, egoística e individualmente; utilizando-se de tudo aquilo ofertado pela natureza, promovendo verdadeira coisificação da

Terra (TOYNBEE, 1979). Talvez não tenha sido exagero o argumento de Toynbee (1979, p.37) quando aponta o homem como "o primeiro dos habitantes da biosfera a ser mais potente que ela própria", detentor de escolhas capazes de "impedir a natureza de liquidá-lo como liquidou outras espécies que se tornaram um estorvo e uma ameaça à biosfera como um todo".

Durante muito tempo a natureza serviu simplesmente como coisa para o homem, o qual mantinha com aquela uma relação individualista de plena superioridade. Assim, após a aquisição da sua percepção consciente, o homem ganha a qualidade de haver se tornado a espécie de ser vivo habitante da biosfera capaz de destruí-la e, por via de consequência, capaz de destruir a si mesmo. 
O desenvolvimento da espécie humana e das suas relações sociais levou a um desenvolvimento científico traduzido em revoluções tanto tecnológicas e científicas quanto industriais que, pouco a pouco foram modificando o cenário da natureza. Daí o homem tornarse, verdadeiramente, seu maior predador e, quando se dá conta, esse já tinha sido apresentado ao progresso econômico, cuja reflexão é tão somente a satisfação da carência material. Sendo assim, a relação entre sociedade e a natureza apresenta uma visão necessariamente antropocêntrica, permanecendo assim, durante muito tempo.

É possível perceber essa perspectiva numa explicação de Morin e Kern (2011), quando tratam das revoluções de concepção do mundo, da terra e do homem e revela que houve um processo de separação do homem da natureza, sem, contudo, se dissociar dela; mas que antes disso foi necessário abandonar-se a ideia de um homem sobrenatural, o qual teve como procedência uma criação separada. A ideia de uso e gozo da natureza, somadas às grandes descobertas tecnológicas, conduziram a humanidade a um caminho no qual se levou à mercantilização da terra. A esse respeito, Polanyi (2012, p. 199) comenta que "aquilo a que chamamos terra é um elemento da natureza inexplicavelmente entrelaçado com as instituições do homem. Isolá-la e com ela formar um mercado foi talvez o empreendimento mais fantástico dos nossos ancestrais".

Desde o advento da percepção consciente, chegando-se à utilização da natureza como produto, incluindo-se também o homem nesse processo, o que se testemunhou na história da humanidade fora um crescimento tanto populacional quanto da produção, que teve como consequências a necessidade de maior e mais veloz exploração dos recursos naturais, forçando o homem e a própria natureza a estarem sempre no limite. Essa observação fora verificada no Relatório da Comissão Mundial sobre Meio Ambiente e Desenvolvimento (1991), já se chamando à atenção para um equilíbrio delicado da natureza ante a sua fragilidade e o tempo escasso para se prevenir e prever efeitos não desejáveis.

O despertar da espécie humana para o sistema de produção capitalista e a chegada para a Revolução Industrial na Inglaterra já no Século XVIII são fatores primordiais no processo da degradação em grande escala do meio ambiente. Enfim, a institucionalização de um sistema de mercado no qual, ambos, homem e natureza são mercadorias, o primeiro como mão de obra e o segundo como terra propriamente dita, caracterizam a produção como interação entre a sociedade e a natureza, como explica Polanyi (2012). Corroborando com esta perspectiva, Castilho e Ferreira (2018, p. 225) lembram não se pode desconsiderar a "unidade indissolúvel entre sociedade e natureza como resultado da inter-relação permanente entre 
sujeitos e espaço como totalidade ambiental socialmente construída". Neste mesmo pensar, Sábato traz que "Este é o homem moderno. Conhece as forças que governam o mundo, temnas a seu serviço, é o deus da terra: é o diabo. Seu lema é: tudo pode ser feito. Suas armas são o ouro e a inteligência. Seu procedimento é o cálculo.” (SÁBATO, 1993, p. 33)

Outrossim, verificou-se que o mercado poderia ditar o destino tanto dessa terra quanto do próprio homem, e por consequência, o poder de exterminá-los, o que justificaria inicialmente a necessária intervenção política e governamental. Polanyi (2012, p. 146) observa:

Todavia, enquanto a produção, teoricamente, podia ser organizada dessa forma, a ficção da mercadoria menosprezou o fato de que deixar o destino do solo e das pessoas por conta do mercado seria o mesmo que aniquilá-los. Assim, o contramovimento se propunha a enfrentar a ação do mercado em relação aos fatores de produção - trabalho terra. Foi esta a função do intervencionismo.

A consciência da finitude dos recursos naturais passa a ser uma preocupação para o homem e para a humanidade. A ideia de coisificação da natureza começa a ganhar contornos de que não pode continuar por longa data, sob pena de um desfecho que poderia seriamente comprometer a própria sobrevivência da raça humana no planeta terra.

Na Comissão Mundial sobre Meio Ambiente e Desenvolvimento, houve a prática de audiências públicas, nas quais, pessoas de classes governistas e grupos de cidadãos foram ouvidos e a percepção extraída, fora a de que há o sentimento de cooperação, em função de uma concreta preocupação com o meio ambiente. $\mathrm{O}$ meio ambiente, portanto, converte-se numa questão política. Contudo, como bem lembra Alier (2014, p. 269) “Os Estados tropeçam com uma agenda ambiental que eles não dominam plenamente e que não os apetece nem um pouco".

Diante do medo de não haver mais um mundo onde viver e habitar, a sociedade passa a perceber que deve mudar. Ao que parece, a mola mestra que representa uma mudança de comportamento e uma nova definição da relação sociedade e natureza, está basicamente no medo. Depois de anos e anos se utilizando da natureza de forma voraz, a sociedade tem desenvolvido à custa da vivência dos danos causados a percepção que precisa protegê-la como se estivesse protegendo a si mesmo. Nessa possibilidade, o homem não se sente mais senhor da natureza; em verdade o homem passa a se incluir na natureza e a assumir a incumbência de ser o seu protetor, verificando ainda que é capaz progredir e preservar. Daí a concepção de que a natureza, como complementação a qualidade de vidado homem, tornar-se alicerce para o estabelecimento de princípios e conceitos do direito socioambiental. 


\section{O DIREITO SOCIOAMBIENTAL E A LEGISLAÇÃO DE PROTEÇÃO/VALORIZAÇÃO DAS COMUNIDADES TRADICIONAIS}

A Conferência das Nações Unidas sobre o Meio Ambiente Humano, ocorrida em Estocolmo na Suécia, surgiu como a reunião precursora da ecopolítica internacional, entre 05 e 16 de junho de 1972, locus de debates e reflexões onde se estabeleceram princípios e conceitos que se tornaram base para a evolução da proteção ao meio ambiente e a construção do Direito Ambiental. As tratativas assinadas em 1972 ganharam poder de normas internacionais vinculantes graças à Convenção de Viena, realizada em 1969. Nessa se firmou a codificação de regras aplicáveis aos tratados escritos sobre matérias de âmbito global. Portanto, a Conferência de Estocolmo conquistou atributos para impor obrigações oponíveis aos seus signatários, agora por força de pacto de Direito Internacional. (FONSECA, 2007)

No ano de 1988, o Brasil definitivamente reserva para a sua nascente constituição, texto alicerçado na tutela ambiental, sendo tal feito bastante comemorado, haja vista que a inovadora norma tratava, a partir de então, de estabelecer princípios maiores. A Constituição Federal de 1988 reconheceu a existência de um bem que não se caracteriza como bem público, tão pouco, como bem privado e, dessa forma, deixou de lado as ideias tradicionais do direito, vinculadas aos institutos da posse e propriedade, consagrando em seu texto uma nova concepção ligada ao direito, os chamados direitos difusos, reconhecendo assim, em relação ao direito ambiental, uma tutela de valores diferenciada. (MARUDI, 2007).

A preocupação com o meio ambiente pelo legislador constitucional, fez inserir na Constituição Federal de 1988, no “Título VIII - Da ordem social”, no capítulo VI, a temática específica "Do Meio Ambiente",

\section{Constituição Federal da República Federativa do Brasil}

Art. 225: Todos têm direito ao meio ambiente ecologicamente equilibrado, bem de uso comum do povo e essencial à sadia qualidade vida, impondo-se ao Poder Público e à coletividade o dever de defendê-lo e preservá-lo para às presentes e futuras gerações.

Precedente à Constituição, A Lei no 6.938 de 31 de agosto de 1981, que dispõe sobre a Política Nacional do Meio Ambiente, conceitua Meio Ambiente como “o conjunto de condições, leis, influências e interações de ordem física, química e biológica, que permite, abriga e rege a vida em todas as suas formas".

Além de consignar a obrigação de preservar o meio ambiente, sendo esta imposta ao Poder Público e à coletividade, a Constituição de 1988 estabeleceu também que a responsabilidade penal não se dirigia somente para as pessoas físicas, mas também alcançava 
as pessoas jurídicas. Estabeleceu medidas e providências cabíveis tanto à União como aos estados e municípios, que se destinam a assegurar a efetividade do meio ambiente equilibrado.

O Direito Ambiental é abarcado na Constituição Federal de 1988, em seu art. 225 no qual assevera sobre a necessidade de um desenvolvimento de forma sustentável, isto é, de forma que as ações humanas não interfiram negativamente no meio ambiente. Com o passar do tempo a área de abrangência desse ramo do direito que cuida das questões pertinentes ao meio ambiente e a proteção da natureza tornou-se cada vez maior trazendo não só para o estudo como para a proteção essa relação homem e natureza, cidadania e evolução social.

Nessa perspectiva, o estudo das comunidades tradicionais é de fundamental importância ao passo que seus saberes devem ser preservados como uma questão de cidadania e de sustentabilidade. O conhecimento é uma forma de saber, que em tudo se sobrepõe ao nãosaber, destacando a importância de se reconhecer e conceder o direito à expressão e proteção às mais variadas formas de conhecimento. Dentre as formas de conhecimento residem os saberes tradicionais que consistem num conjunto de informações que são formados por meio da memória coletiva de um grupo, transmitidos oralmente. (BRUNO, 2015)

Nas palavras de Bertoldi (2012, p. 79) “os conhecimentos tradicionais são práticas, experimentações e inovações consuetudinárias dinâmicas, transmitidas entre gerações comumente via oral; constituem a memória viva, a história desses povos." Nesta esteira, cumpre ressaltar que o desenvolvimento sustentável é transdisciplinar e se sustenta sobre três pilares ou dimensões, quais sejam: o social, o econômico e ambiental. Isto é, assenta-se sob um tripé formado por três dimensões básicas da sociedade. Sob a perspectiva econômica exige eficiência social na alocação e gestão de recursos públicos. Pugna pela implementação de uma justiça ambiental intergeracional, preocupando-se com os impactos negativos das atividades humanas no meio ambiente, de modo que o desenvolvimento deve permitir às gerações futuras, o acesso a um meio ambiente sadio e necessário à qualidade de vida. (CARVALHO; LÉLIS, 2013)

Então, deve-se promover a utilização sustentável da biodiversidade, ou seja, a utilização de componentes da diversidade biológica de modo e em ritmo tais que não levem, no longo prazo, à diminuição da diversidade biológica, mantendo assim seu potencial para atender as necessidades e aspirações das gerações presentes e futuras. (RESENDE, 2013). Nesse sentido, ganham-se importância os conhecimentos tradicionais das comunidades, isto é, os saberes coletivos apoiados na tradição e expressados através de mitos, rituais, narrações de 
caráter oral e práticas relacionadas com sistemas de ordem ambiental e de saúde, com instituições e regulamentos estabelecidos para lhes aceder e para os aplicar, aprender e transmitir. (ALONSO, 2005)

As comunidades tradicionais são identificadas quando um grupo de pessoas preenche quatro características específicas, a saber: a) compartilham as referências constitutivas de uma identidade cultural em comum, desejando preservá-la e desenvolvê-la; b) conservam formas próprias de organização social; c) usam recursos naturais como condição para a sua reprodução cultural, social e econômica; e d) conservam e transmitem conhecimentos, práticas e expressões culturais para as gerações futuras, segundo as tradições herdadas de seus antepassados. A partir da análise dessas comunidades é possível identificar nelas uma carga de conhecimento sustentável, que é transmitida hereditariamente. (BERTOLDI, 2012)

Os conhecimentos tradicionais são os saberes das sociedades tradicionais relacionados à conservação e utilização sustentável da diversidade biológica porque tais conhecimentos foram desenvolvidos em interação direta e harmônica com a natureza, de modo que a conservação da biodiversidade depende da preservação dos conhecimentos tradicionais, que refletem as relações simbióticas entre o homem e a natureza, e do vínculo das comunidades locais com a natureza sob a perspectiva sustentável. Constituem importante contribuição para a conservação e o uso sustentável da biodiversidade, sua mais ampla aplicação pode favorecer o bem-estar social e os modos sustentáveis de subsistência. Deste modo, faz-se de extrema importância o reconhecimento jurídico dessas comunidades, bem como a garantia de seus direitos. A partir dos instrumentos de proteção aos conhecimentos tradicionais, essas comunidades poderão se manter socialmente e preservar os fazeres que favorecem uma evolução sustentável do meio ambiente.

As comunidades tradicionais são juridicamente definidas na Lei $\mathrm{n}^{\circ} 13.123$, de 20 de maio de 2015, que estabelece comunidade tradicional como um grupo humano distinto por suas condições culturais, que se organiza, tradicionalmente, por gerações sucessivas e costumes próprios, e que conserva suas instituições sociais e econômicas, de perspectiva socioambiental.

Segundo o Decreto $\mathrm{n}^{\circ}$ 6.040, de 07 de fevereiro de 2007, que institui a Política Nacional de Desenvolvimento Sustentável dos Povos e Comunidades Tradicionais - PNPCT, Povos e Comunidades Tradicionais podem ser definidos como:

[...] grupos culturalmente diferenciados e que se reconhecem como tais, que possuem formas próprias de organização social, que ocupam e usam territórios e recursos naturais como condição para sua reprodução cultural, social, religiosa, 
ancestral e econômica, utilizando conhecimentos, inovações e práticas gerados e transmitidos pela tradição;

As comunidades tradicionais são portadoras de culturas únicas voltadas à utilização sustentável dos recursos da biodiversidade. A natureza é, para as comunidades locais, um sustentáculo de identidade cultural e de sobrevivência material, de modo que a proteção da integridade cultural das comunidades tradicionais enseja necessariamente a conservação da natureza (SANTOS, 2008). Desse modo, para além de reconhecimento jurídico, é necessária a proteção desses grupos, obtendo-se assim, a preservação de um valioso tipo de consciência ambiental, visando a satisfação das necessidades das gerações presentes e futuras. Para tanto, assevera a Magna Carta de 1988 que, cabe ao Estado garantir a todos o pleno exercício dos direitos culturais e acesso às fontes de cultura, bem como, deve assegurar a proteção às manifestações culturais populares (BRASIL, 1988). Ainda define como patrimônio cultural brasileiro, os bens de natureza material e imaterial que se constituem de referência à identidade, à ação e à memória dos diferentes grupos da sociedade brasileira.

Além das garantias de direitos das sociedades tradicionais encontradas no texto da Constituição Federal, algumas convenções também foram primordiais para a proteção desses conhecimentos, como a Convenção sobre a Proteção e Promoção da Diversidade das Expressões Culturais, de 20 de outubro de 2005 e assinada pelo Brasil em 2007, e determinada pelo Decreto $\mathrm{n}^{\mathrm{o}}$. 6.177, de $1^{\mathrm{o}}$ de agosto de 2007, que destaca o quão fundamentais são os conhecimentos tradicionais e suas contribuições para o desenvolvimento sustentável cabendo, deste modo, a sua proteção e promoção. A convenção traz à tona alguns objetivos como: a) proteger e promover a diversidade das expressões culturais; b) criar condições para que as culturas floresçam e interajam livremente em benefício mútuo; c) promover o respeito pela diversidade das expressões culturais e a conscientização de seu valor nos planos local, nacional e internacional; d) reafirmar a importância do vínculo entre cultura e desenvolvimento para todos os países, especialmente para países em desenvolvimento; e) reconhecer a natureza específica das atividades, bens e serviços culturais enquanto portadores de identidades, valores e significados.

A relação existente entre a comunidade tradicional e o meio ambiente que a rodeia é uma espécie de ligação inseparável. Ambas convivem de forma que a sobrevivência de um depende do outro. A comunidade vê a natureza como um ser vivo único que possui necessidades específicas, como ela mesma. Não há como se entender a perfeita relação que as comunidades possuem com a natureza, analisando ambas separadamente. Estas comunidades 
tradicionais, guardiãs de um rico e ameaçado saber compartilham estilos de vida particulares, fundada na natureza, nos conhecimentos e nas melhores práticas para conservá-la e utilizá-la sustentavelmente, respeitando, desse modo, sua capacidade de recuperação e conservação.

Desta forma, disseminar o conhecimento da real importância dessas comunidades para a região em estudo, vai além da preservação de uma cultura, ou de manutenção de condições de vida para as futuras gerações, é promover um olhar ecológico para o meio ambiente, é encontrar no meio ambiente um local digno de direitos. Nesse sentido, essas comunidades transferem esses conhecimentos adiante, promovendo uma visão holística e de uso e convivência sustentável da natureza.

\section{COMUNIDADES TRADICIONAIS NO OESTE DA BAHIA}

O que chamamos atualmente de Oeste Baiano fazia parte do sertão do São Francisco. Por se tratar de uma região de fronteira ela possui uma história atrelada a outros Estados como Pernambuco e Minas Gerais. Nos primeiros anos após a independência a Comarca do Rio São Francisco (que compõe o que chamamos de sertão do São Francisco) chegou a pertencer a três províncias diferentes do Império do Brasil.

Importante esclarecer que a pesquisa se dá no Bioma do Cerrado do Oeste da Bahia. O cerrado é o segundo maior bioma da América do Sul, ocupando uma área de $2.036 .448 \mathrm{~km} 2$, cerca de $22 \%$ do território nacional. A sua área contínua incide sobre os estados de Goiás, Tocantins, Mato Grosso, Mato Grosso do Sul, Minas Gerais, Bahia, Maranhão, Piauí, Rondônia, Paraná, São Paulo e Distrito Federal, além dos encraves no Amapá, Roraima e Amazonas (FELFILI; SILVA JÚNIOR, 2011). Faz-se necessário destacar a importância do Cerrado no cenário nacional, destacado na Figura 1. Este bioma ocupa significativa área geográfica do Brasil e, por estar localizado na porção central do país, faz contato com quatro dos seis biomas brasileiros, a saber: Floresta Atlântica, na porção sudoeste; Caatinga, na porção nordeste; Pantanal, na porção oeste; e ao norte faz contato com a Floresta Amazônica (FELFILI; SILVA JÚNIOR, 2011). 
Figura 1 - Bioma do Cerrado

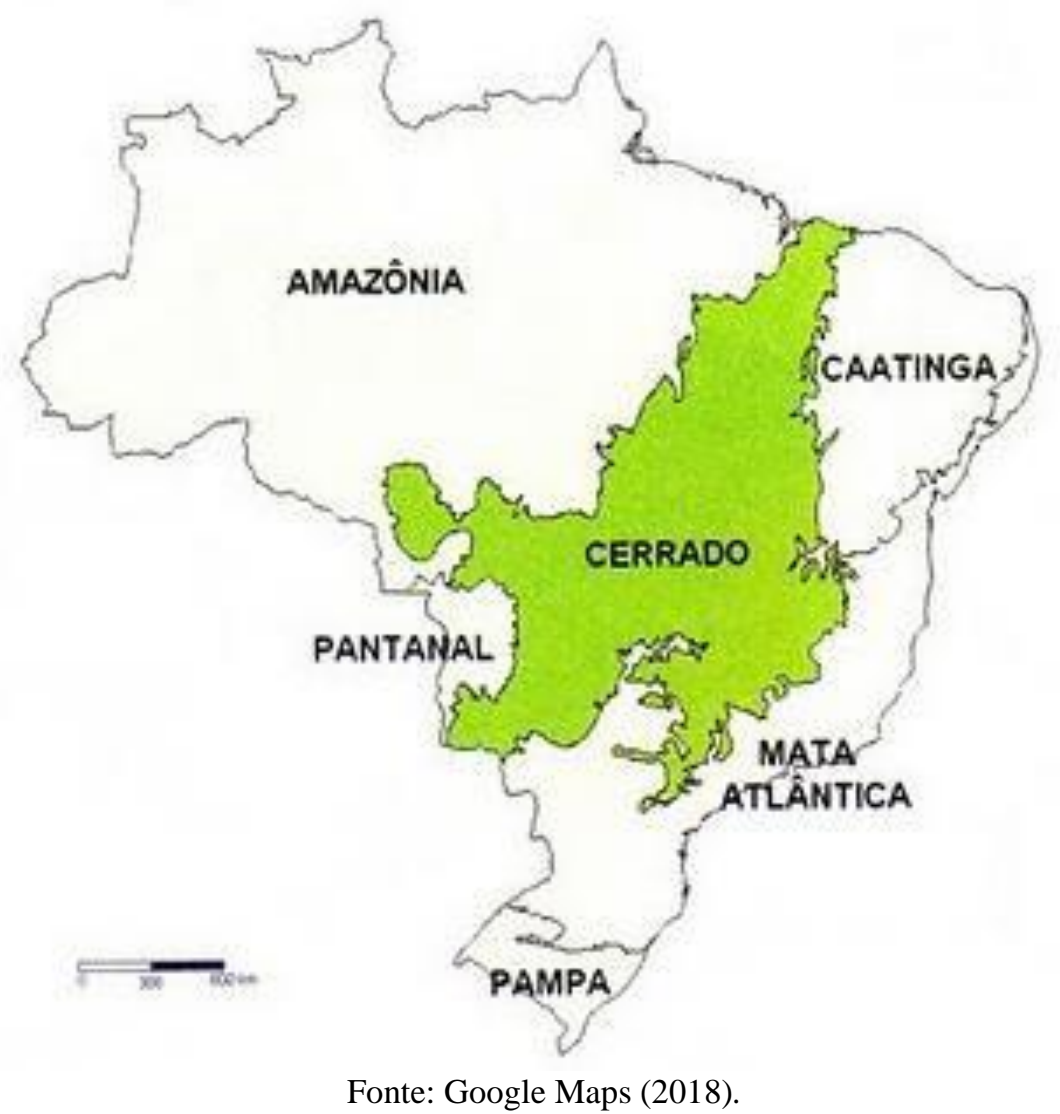

As fisionomias de cerrado (cerradão, cerrados, campo sujo e campo limpo) têm sua distribuição condicionada principalmente pela precipitação sazonal (invernos secos e verões chuvosos), fertilidade e drenagem do solo, regime de fogo e flutuações climáticas do Quaternário (OLIVEIRA-FILHO; RATTER, 2014). Fatores mencionados como principais condicionantes das savanas mundiais (FURLEY et al., 1992).

É dentro deste cenário, que na década de setenta do século passado, o Oeste da Bahia passa a ser reconhecido, antes denominado de sertão do rio São Francisco como um território ocupado em extremo desenvolvimento. Dessa forma, a propriedade fundiária representava seu poderio, mesmo que não fosse a única, surgindo então, a reconhecida frase reconhecida popularmente e em pesquisa traga pelo livro Oeste da Bahia: "O comércio para enriquecer e a terra para ter poder".

Ainda que caracterize, esta condição não abrange a maioria da população, o que se atenta a assuntos que permeiam toda a região, como a problemática da terra e sua apropriação, estando diretamente ligada a sua ocupação e exploração, também o movimento social, que indica a Bahia como um território de tensões e disputas, não só no Oeste, e a formação da 
sociedade regional que faz nascer as associações e sociedades tradicionais diversas. Além do problema ambiental causado pela exploração, já citado, destaca-se a desarticulação política da região.

A ocupação intensiva e a inserção na política de expansão econômica nacional colocam a biodiversidade do Cerrado em estado de alerta. Nesta perspectiva, Barbosa chama a atenção para o fato de que este bioma é um ambiente que depende de vários elementos. Isso significa que já chegou em seu clímax evolutivo. Ou seja, uma vez degradado não vai mais se recuperar na plenitude de sua biodiversidade. Por isso é que falamos que o Cerrado é uma matriz ambiental que já se encontra em vias de extinção (BARBOSA, 2014).

É diante deste cenário que se vislumbra um caminho para abordagens diversas diante do estudo das sociedades tradicionais, as quais trazem consigo seus direitos, sua natureza, e as noções de desenvolvimento sustentável que também constroem a história do Oeste da Bahia, e deve ser abordada. Tendo em vista a riqueza da biodiversidade do cerrado, e em especial a região Oeste, faz-se necessário um levantamento das sociedades tradicionais que ocupam esse território, transmitindo seus saberes e consequentemente contribuindo para um meio ambiente ecologicamente sustentável.

É sob este contexto que esta pesquisa visa identificar num primeiro momento a mesorregião considerada o locus da pesquisa e as sociedades tradicionais consideradas na dimensão regional do Oeste da Bahia, caracterizada na Figura 2. Assim, nos termos desta pesquisa e na região delimitada são consideradas comunidades tradicionais os povos Quilombolas, os Ribeirinhos, os Indígenas, os Geraizeiros, os Cerradeiros, os Pescadores, os Assentados e as comunidades de Fundo e Fecho de Pasto. 
Figura 2 - Oeste Baiano

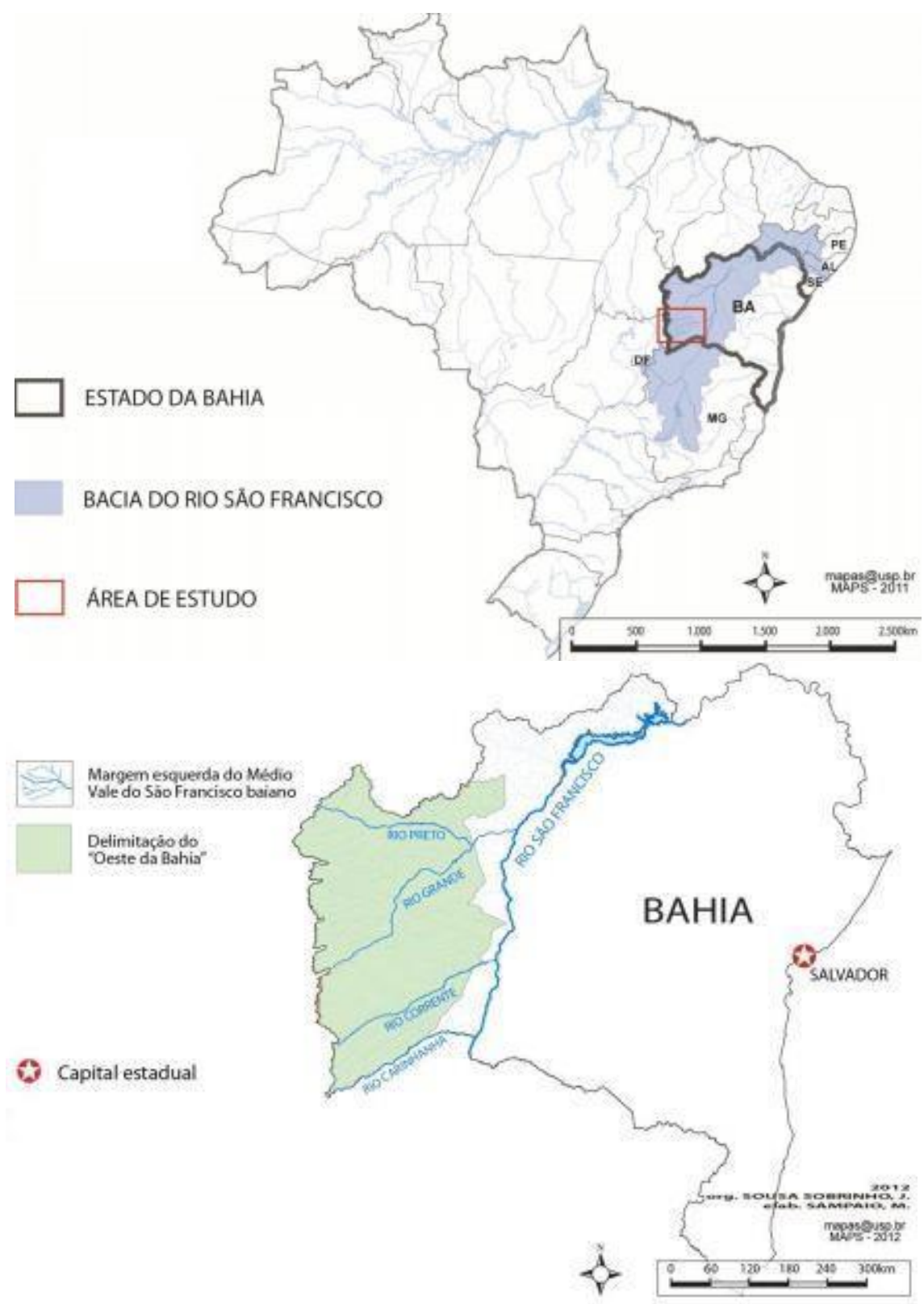

Fonte: Google Maps (2018).

A Tabela 1 apresenta um mapeamento das sociedades tradicionais localizadas na região oeste da Bahia, e em quais territórios elas são encontradas. Nessa perspectiva, podemos identificar a importância que cada sociedade desenvolve nos territórios do ponto de vista da manutenção da flora e fauna regional, bem como da preservação cultural dos seus conhecimentos. 
Tabela 1 - Sociedades Tradicionais do Oeste Baiano

\begin{tabular}{|c|c|}
\hline $\begin{array}{l}\text { Sociedades } \\
\text { Tradicionais }\end{array}$ & Territórios do Oeste da Bahia \\
\hline Quilombolas & $\begin{array}{l}\text { Mucambo (Barreiras), Sacutiaba e Cachimbo (Wanderley), Torrinha (Barra), Jatobá } \\
\text { (Muquém do São Francisco e Sitio do Mato), Riacho do Meio (Buritirama), Boa Vista do } \\
\text { Pixaim, Fazenda Grande } \\
\text { (Muquém do São Francisco), Gregório (Cotegipe), Santo Antônio dos Negros, Engenho } \\
\text { (Santa Rita de Cássia) }\end{array}$ \\
\hline Ribeirinhos & $\begin{array}{l}\text { Tabatinga, Gregório, Tapera, Camaleão, Tabatinguiha (Cotegipe), Gerais do rio Preto, } \\
\text { Aldeia, Gato, Cassimbinha, Cachoeira (Formosa do Rio Preto), Emvalçador ((São } \\
\text { Desidério) }\end{array}$ \\
\hline Indígenas & kiriris (Muquém do São Francisco) Acroás (Angical) Kiriris (Barreiras) \\
\hline $\begin{array}{l}\text { Geraizeiros } \\
\text { e } \\
\text { Cerradeiros }\end{array}$ & $\begin{array}{l}\text { Ponte de Mateus, Cera, Pedras, Currais, Larga, Vereda Grande, Lagoa dos Buristis, } \\
\text { Contagem (São Desidério) }\end{array}$ \\
\hline Pescadores & São José (Riachão das Neves), Macambira, Jupaguá (Cotegipe) \\
\hline Assentados & $\begin{array}{l}\text { São Francisco de Assis, Rio Grande II, Beira Rio II (Cotegipe), Angical I (Angical), } \\
\text { Itacutiara, Sitio Novo, Ferradura, Uirapuru, Angico, São Francisco, Periperi, Vale do } \\
\text { Boqueirão, Ribeirão (Barra), Ilha da Liberdade (Barreiras), Luz da Redenção } \\
\text { (Buritirama), Nova Terra (Formosa do Rio Preto), Rio de Ondas (Luis Eduardo } \\
\text { Magalhães) Nova Esplanada I, Nova Esplanada CAPEFE (Mansidão), Serra Branca, } \\
\text { Anice, Santa Bárbara, Manoel Dias (Muquém do São Francisco), Rio Branco, Carlota, } \\
\text { Dom Ricardo (Riachão das Neves), Senhor do Bomfim, Antônio Conselheiro II, Faz. } \\
\text { Reunidas Esplanada, Primavera CAPEFE, Beira Rio ( Santa Rita de Cássia), Tainá, } \\
\text { Vitória, Águas Claras, Caxiado (São Desidério), Senhor do Bomfim (Tabocas do Brejo } \\
\text { Velho), Campo Alegre (Wanderley) }\end{array}$ \\
\hline $\begin{array}{l}\text { Fundo e } \\
\text { Fecho de } \\
\text { Pasto }\end{array}$ & Val da Boa Esperança (Barreiras) \\
\hline
\end{tabular}

Fonte: Elaboração dos autores (2018).

Partindo da análise de Bicalho (2015), no caso específico de populações indígenas e comunidades tradicionais em sentido amplo, o conceito de desenvolvimento sustentável se assemelha do que Stavenhagen (1984 apud BICALHO, 2015) chamou de Etnodesenvolvimento, ou seja, "desenvolvimento de grupos étnicos no interior de sociedades mais amplas". Desta forma, é proposto um tipo de desenvolvimento alternativo como ferramenta de aproveitamento econômico do território, respeitando a tradicionalidade dos sujeitos históricos; os saberes locais; a biodiversidade e as fragilidades do bioma Cerrado.

[...] a abordagem procura usar e aproveitar as tradições culturais existentes, e não rejeitá-las a priori, como obstáculos ao desenvolvimento [...] se propõe a respeitar, e não destruir, o meio-ambiente, ou seja, é válida do ponto de vista ecológico [...] a abordagem do desenvolvimento alternativo estaria baseada, sempre que possível, no uso dos recursos locais, quer sejam naturais, técnicos ou humanos; ou seja, ela se orienta para a autosustentação, nos níveis local, nacional e regional [...] esta abordagem, nova e alternativa, pretende ser mais participante do que tecnocrática. (STAVENHAGEN, 1984, p. 17-19 apud BICALHO, 2015, P.58)

O Cerrado e em especial a região Oeste da Bahia, é um ambiente que por possuir uma vegetação rica se encontra bastante visado do ponto de vista econômico, como por exemplo, a 
partir do agronegócio, o que promove uma ampliação da devastação desse bioma. Segundo Avidos e Ferreira (2000), a maioria dos agricultores utilizam os recursos naturais, como a fauna e a flora, erroneamente, na expectativa de maximizarem seus lucros. Neste tocante, o ecossistema cerrado tem sido agredido e devastado pela ação do fogo e dos tratores, colocando em risco de extinção várias espécies de plantas.

Desta forma, partindo de uma análise holística do meio ambiente, e buscando garantir os direitos constitucionais que o artigo 225 nos propõe, a preservação dessas sociedades tradicionais é de fundamental importância. Sabe-se que em um ambiente rico em vegetações e que se encontra em iminente risco de extinção como a região Oeste da Bahia, a participação dessas populações garante não só uma manutenção natural e sustentável, como a passagem de uma perspectiva cultural e socioambiental para as futuras gerações. Para tanto, essa pesquisa não finda neste textos, mas apenas apresentar seu objetivo inicial sob a perspectiva do desenvolvimento do Direito Socioambiental, que é apresentar essas sociedades e em quais territórios estão dispostas, para a população compreender a importância que elas possuem para a preservação e conservação do direito, da natureza e do desenvolvimento sustentável..

\section{CONSIDERAÇÕES FINAIS}

$\mathrm{Na}$ segunda metade do Século XX, alguns países organizaram conferências internacionais para discutir sobre a interferência humana na natureza e quais os caminhos deveriam ser trilhados almejando a preservação do meio ambiente. Assim, acordos foram celebrados a fim de estabelecer diretrizes que norteassem um novo conceito de desenvolvimento, bem como introduzissem a defesa do ambiente sob a forma de normatização. Isso foi consequência da tomada de consciência pelo homem sobre sua relação com a natureza e sua sustentabilidade, mudança de consciência a que fora submetido o homem ao longo da sua história, responsável por uma modificação de paradigma na relação homem-natureza, ao que se compreende, apresenta-se como a base para a percepção de um cidadão ambiental. Este é o cidadão no qual os ordenamentos jurídicos pelo mundo lhes foram atribuindo e consagrando princípios e direitos para com o meio ambiente, ao tempo em que lhe imputavam o dever de sua proteção e garantia, juntamente com o Poder público.

Provocar a ruptura do sistema que se implantou neste último século determinaria um novo modelo de vida a ser almejado pelo homem, necessitando-se alterar o modo de se relacionar com todo o sistema ecológico, passando-se por fortes mudanças culturais e sociais, 
a fim de definir, então, o pensamento ecocêntrico como estilo propício à manutenção da vida, à preservação de todo e qualquer ambiente. A mudança de foco orienta para elaboração de leis pautadas não mais na visão antropocêntrica, mas agora, acima disso, numa visão holística, ecocêntrica. Essa nova abordagem estabelece a equiparação de valores entre todos os organismos que compõem o meio ambiente e que dele formam um sistema completo.

Ao abordar a importância dos povos e suas culturas tradicionais, o envolvimento socioambiental, as perspectivas jurídicas, agroecológicas em entorno do próprio desenvolvimento do direito das comunidades tradicionais da Região Oeste da Bahia, a pesquisa aponta que há instalado um processo de desvalorização dessas comunidades e de seus saberes, privando-as do direito ambiental. Ainda são necessários estudos aprofundados que busquem dimensionar o impacto desse descompasso.

\section{REFERÊNCIAS}

ALIER, Joan Martínez. O Ecologismo dos Pobres: conflitos ambientais e linguagens de valoração. São Paulo: Contexto, 2014.

ALONSO, Margarita Florez. Proteção do conhecimento tradicional? In SANTOS, B. S. Semear outras soluções: o caminho da biodiversidade e dos conhecimentos rivais. Rio de Janeiro: Civilização Brasileira, 2005. p. 287-317.

BERDOULAY. Vincent. Espaço e Cultura. In: CASTRO, Iná Elias de; GOMES, Paulo Cesar da Costa; CORRÊA, Roberto Lobato (Orgs.). Olhares Geográficos: modos de ver e viver o espaço. Rio de Janeiro: Bertrand Brasil, 2012.

BERTOLDI, Márcia Rodrigues; SPOSATO, Karyna Batista. Instrumentos de proteção dos conhecimentos tradicionais associados à biodiversidade. Revista de Direitos Fundamentais e Democracia, Curitiba, v. 12, n. 12, p. 75-93, julho/ dezembro de 2012.

BRASIL. Constituição (1988). Constituição da República Federativa do Brasil. Brasília, DF: Senado, 1988.

BRASIL. Decreto $\mathrm{n}^{\circ}$ 6.040, de 07 de fevereiro de 2007. Institui a Política Nacional de Desenvolvimento Sustentável dos Povos e Comunidades Tradicionais. Diário Oficial [da] República Federativa do Brasil, Brasília, DF, 7 fev. 2007. Disponível em: < http://www.planalto.gov.br/ccivil_03/_ato2007-2010/2007/decreto/d6040.htm>. Acesso em: 06 maio 2018.

BRUNO, Flávio Marcelo Rodrigues. Manuscritos de Direito Socioambiental: sobre o Buen Vivir, a Cidadania Socioambiental, os Créditos de Carbono, e os limites da Bioética. North Charleston (USA): Amazon, 2015. 
CARVALHO, Fábia Ribeiro Carvalho de; LELIS, Acácia Gardênia Santos. A conquista de um espaço para a cata da mangaba em meio a omissões e tropeços. In: SOUZA FILHO, Carlos Frederico Marés de; SILVA, Liana Amim Lima da; WINADSCHEER, Clarissa Bueno. Biodiversidade, espaços protegidos e populações tradicionais. Curitiba: Letra da Lei, 2013.

CASTILHO, Cláudio Jorge Moura de; FERREIRA, Rubio José. (Des) Caminhos nas InterRelações Entre Rio e Cidade: escuta e participação dos territórios vividos como caminho possível In: CASTILHO, Cláudio Jorge Moura de (Org.). Natureza, impactos ambientais e espaço vivido. Recife: Ed. UFPE, 2018.

CLAVAL, Paul. As Abordagens da Geografia Cultural. In: CASTRO, Iná Elias de; GOMES, Paulo Cesar da Costa; CORRÊA, Roberto Lobato (Orgs.). Explorações Geográficas: percursos no fim do século. Rio de Janeiro: Bertrand Brasil, 2006.

COMISSÃO MUNDIAL SOBRE MEIO AMBIENTE E DESENVOLVIMENTO. Nosso

futuro comum. Rio de Janeiro: Fundação Getúlio Vargas, 1991.

FELFILI, J. M.; SILVA JÚNIOR, M. C.. Diversidade alfa e beta no cerrado sensu stricto, Distrito Federal, Goiás, Minas Gerais e Bahia. p.143-154. In: SCARIOT, A.; BARBOSA, A.

S. Cerrado: "dor fantasma" da biodiversidade brasileira. In: Entrevista à Revista do Instituto Humanitas Unisinos. Ed. 382. São Leopoldo, 28 de novembro de 2011 p. 11-15.

FONSECA, F. Eduardo. A Convergência entre a Proteção Ambiental e a Proteção da Pessoa Humana no Âmbito do Direito Internacional. Revista Brasileira de Política Internacional (Impresso), v. 50, p. 121-138, 2007.

FURLEY, P. A.; PROCTOR, J.; RATTER, J. A. Nature and dynamics of forestsavanna boundaries. Chapman \& Hall, London.Furley, P.A. \& Ratter, J.A. 1988. Soil resources and plant communities of the central Brazilian cerrado and their development. Journal of Biogeography 15(1): 97-108, 1992.

GONÇALVES, Calos Walter Porto. Os (Des)caminhos do Meio Ambiente. São Paulo: Contexto, 2014.

MARUDI, Sandra Mára Ribeiro. O Direito Ambiental no Brasil. Notas de conjuntura da ESPM Publicação de responsabilidade do Depto. de Economia e Direito da ESPM. 2009

MORIN, Edgar; KERN, Anne Brigitte. Terra-Pátria. Tradução de Paulo Neves da Silva. Porto Alegre: Sulina, 2011.

OLIVEIRA FILHO, N. L.; FREITAS, R. C. J.; MIRANDA, S. C. Importância e a contribuição de von martius para o conhecimento da flora arbórea do cerrado. Revista Sapiência: sociedade, saberes e práticas educacionais - UEG/Câmpus de Iporá, v.3, n. 2, p. $22-43$ - jul/dez 2014.

POLANYI, Karl. A grande transformação: as origens de nossa época. Rio de Janeiro: Campus-Elsevier, 2012.

RESENDE, Augusto César Leite de. A proteção jurídica dos conhecimentos tradicionais: um olhar através do patrimônio cultural imaterial. In: SOUZA FILHO, Carlos Frederico Marés 
de; SILVA, Liana Amim Lima da; WINADSCHEER, Clarissa Bueno. Biodiversidade, espaços protegidos e populações tradicionais. Curitiba: Letra da Lei, 2013.

SÁBATO, Enesto. Homens e Engrenagens: reflexões sobre o dinheiro, a razão e a derrocada de nosso tempo. Tradução: Janer Cristaldo. Campinas: Papirus, 1993.

SANTOS, Clóvis Caribé Menezes dos. Os cerrados da Bahia sob a lógica do Capital. Revista IDeAS, v. 2, n. 1, p. 76-108, jan.-jun. 2008.

SANTOS, Clóvis Caribé Menezes dos; VALE, Raquel. Oeste da Bahia: trilhando velhos e novos caminhos do além, São Francisco. Feira de Santana UESFS editora, 2012.

TOYNBEE, Arnold. A humanidade e a Mãe-Terra: uma história narrativa do mundo. Tradução de Helena Maria Camacho Martins Pereira. Rio de Janeiro: Zahar Editores, 1979. 


\title{
COMPLEXIDADE E TRANSDISCIPLINARIDADE: DESAFIOS E POSSIBILIDADES NA OPERACIONALIZAÇÃO COLETIVA DE PESQUISAS SOBRE O AMBIENTE
}

\author{
Gabriela Macedo Aretakis de Almeida ${ }^{46}$ \\ Gilberto Queiroz de Lima Filho ${ }^{47}$ \\ José Eleno da Silva ${ }^{48}$ \\ Lívia Câmara Machado 49 \\ Lywistone Galdino da Silva ${ }^{50}$ \\ Manuela Maria Pereira do Nascimento ${ }^{51}$ \\ Patrícia Alves Pereira ${ }^{52}$ \\ Plínio Guimarães de Sousa ${ }^{53}$ \\ Vanessa Bastos Simões da Costa ${ }^{54}$ \\ Tiago Henrique de Oliveira ${ }^{55}$
}

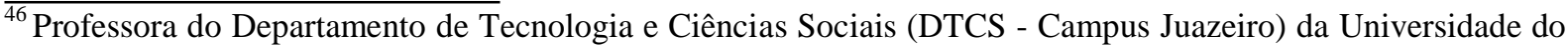
Estado da Bahia (UNEB). Doutora em Desenvolvimento e Meio Ambiente (PRODEMA) da Universidade Federal de Pernambuco (UFPE). E-mail: gabiaretakis@ hotmail.com.

${ }^{47}$ Biólogo, com mestrado e doutorado no Programa de Pós-Graduação em Desenvolvimento e Meio Ambiente (PRODEMA/UFPE). Analista ambiental e gerente de monitoramento e fiscalização da Agência Pernambucana de Águas e Clima. E-mail: gilbertofilho.queiroz@gmail.com.

${ }^{48}$ Bacharel, Licenciado e Mestre em Geografia pela Universidade Federal de Pernambuco - UFPE. Pesquisador na área de Geografia e História Cultural na UNIVISA. E-mail: jeleno@ terra.com.br.

${ }^{49}$ Bióloga e Doutora em Desenvolvimento e Meio Ambiente pela UFPE, professora da pós-graduação na Faculdade Juazeiro do Norte (FJN) e na CENTEC-FATEC Cariri, atualmente é Gestora da Eco.Sustentabilidade - Projetos e Educação em Meio Ambiente. E-mail: liviamachado.biologa@gmail.com.

${ }^{50}$ Licenciado e Mestre em Geografia pela Universidade Federal de Pernambuco - UFPE. Atua como Analista Educacional e Gestor Escolar. E-mail: lywistone@gmail.com.

${ }^{51}$ Graduada em Geografia (UFPE). Doutora em Desenvolvimento e Meio Ambiente pela Universidade Federal de Pernambuco (PRODEMA - UFPE). Professora e Analista de Sistemas de Informações Geográficas na Prefeitura Municipal de Aracaju/SE. E-mail: manuelanascimento@yahoo.com.br.

${ }^{52}$ Graduada em Licenciatura em Ciências Biológicas (Universidade Estadual da Paraíba-UEPB), Mestre em Manejo de Solo e Água (Universidade Federal da Paraíba-UFPB). Analista ambiental na Secretaria de Serviços e Meio Ambiente- Campina Grande-PB. E-mail: patriciaalves19@gmail.com.

${ }^{53}$ Bacharel em administração de empresas, especialista em jornalismo digital, mestre e doutor em Desenvolvimento e Meio ambiente. Professor do IFPE - Campus Barreiros. Diretor Geral do IFPE - Campus Palmares. E-mail: plinioguimaraesdesousa@hotmail.com.

${ }^{54}$ Bacharela e Licenciada em Ciências Biológicas (UFRPE), Mestre em ecologia (UFRPE), Doutora em desenvolvimento e meio ambiente (PRODEMA/UFPE). Professora técnica da Secretaria de Educação e Esportes de Pernambuco. E-mail: vanessabastos_simoes@hotmail.com.

${ }^{55}$ Doutor em Desenvolvimento e Meio Ambiente, Gerente de Análise e Geoprocessamento do Instituto da Cidade Pelópidas Silveira, Prefeitura da Cidade do Recife. E-mail: thdoliveira50@ gmail.com.
} 


\section{O PRODEMA E AS POSSIBILIDADES DE EXPERIÊNCIA COLETIVA}

Para compor um cenário de análise alternativo perante questões ambientais, são necessários esforços a fim de encontrar o que é transversal e convergente, visando à diminuição dos dualismos que simplificam a realidade observada. Esse sentimento (por vezes angustiante, para quem se depara com as "novidades" de programas interdisciplinares ou que envolvem a complexidade de análises ambientais), assim como a urgência de realizar algo que ultrapasse as políticas de sentido que naturalmente carregamos pelas nossas formações disciplinares, são marcas valiosíssimas do PRODEMA - Programa de Pós-Graduação em Desenvolvimento e Meio Ambiente.

Foi nesse contexto de descobertas e aprendizado diverso que resolvemos (alunos e alunas das primeiras turmas - 2013 e 2014 - da Universidade Federal de Pernambuco no Doutorado em Rede), realizar um experimento coletivo para vivenciar e aprender mais sobre aqueles conceitos e inovações teórico-metodológicas que emergiam diante de nós. Era um momento também de responder a uma inquietação: isso é possível? Ser interdisciplinar, ser "multi" ou transdisciplinar diante dos nossos objetivos, nossas ideias, nossa formação? O que teríamos que refletir ou repensar para chegar a metodologias não disciplinares ou duais?

Foi assim que, partindo de noções relativas ao pensamento complexo e da abordagem transdisciplinar (que naquele momento nos eram apresentados, juntamente com uma enxurrada de novos conceitos), buscamos abrir mão da necessidade de demarcações de fronteiras disciplinares e da divisão de tarefas numa investigação de uma temática ambiental, utilizando-se para isto, a construção coletiva de um objeto de análise efetivamente comum para o grupo envolvido e a busca da convergência de percepções. Realizou-se um processo de pesquisa em grupo, operacionalizado por meio das escolhas temáticas dos participantes, da realização de sínteses interpretativas e interpretação conjunta do conteúdo produzido.

Esperamos que o relato dessa experiência seja elucidativo e inspirador, para as pessoas que, como nós, estão nesse processo de imersão em uma cultura interdisciplinar, ou para quem ainda (como desejamos) queira se aventurar.

\section{DEBATES INICIAIS}

A fim de compor uma experiência divergente frente aos paradigmas mais usuais, são necessários maiores esforços reflexivos para encontrar o que está "através" das relações de 
causa e efeito ante os problemas observados, visando diminuir a simplificação excessiva dos fenômenos, ou pior, fomentar a geração de extremos e oposições desprovidas de sentido.

Desta maneira, ao invés do foco teórico-metodológico direcionar-se para segmentos da realidade ou metas específicas, tentou-se buscar as convergências que surgiram a partir do momento em que todos analisariam um objeto que não foi imposto, fruto de deliberações imediatistas ou fracionado para sua melhor apreensão, mas sim, seria analisado aquele que demandasse maior esforço reflexivo e/ou teve maiores recorrências cognitivas no grupo.

De forma mais específica, objetivou-se a realização de um processo de pesquisa em grupo a respeito de uma questão ambiental emergente, tendo em vista sua efetivação e possiblidade de avaliação, ao final, como "inter", "pluri”, “multi” ou transdisciplinar.

Como mote inicial para o debate, utilizamos leituras comuns solicitadas a todos no PRODEMA e, dentre elas, duas noções se sobressaíram na percepção coletiva para dar fundamento à análise de temáticas ambientais:

Souza Santos (2007) aponta dois elementos inerentes à razão do homem ocidental: por um lado, existe a consciência que nosso futuro individual é limitado, pois nossa vida como espécie é limitada e por isso, tanto quanto é possível, cuidamos de nossa saúde, de nossa alimentação, dentre outras necessidades; por outro lado, contudo, afirma que com respeito à concepção de sociedade e ambiente não ocorre o mesmo, pois "não seria necessário cuidar do futuro", uma vez que, por maiores que sejam as evidências com relação ao esgotamento de recursos naturais e desequilíbrios sociais, não se vislumbra objetivamente um "fim" credível $^{56}$.

Independentemente desse raciocínio - e mesmo considerando uma relação quanto aos fenômenos ambientais fundamentada no ceticismo, ou seja, com base em um conteúdo filosófico que reconhece a possibilidade de o conhecimento depender das limitações da mente ou da impossibilidade do sujeito acessar o objeto a ser conhecido (KORTE, 2001) - observase a emergência de uma ampla diversidade de efeitos adversos nas intervenções humanas, que demandam outras maneiras de analisar o ambiente.

Estas consequências afetam o presente e geram inquietações para o futuro, são recorrentes nas mídias em geral ou, em estudos científicos nos quais são construídos diversos cenários, modelagens e simulações. Infelizmente, por vezes as pesquisas científicas não chegam adequadamente ao conhecimento geral ou pior, de forma superficial ou distorcida são desacreditadas, são subjugadas por crenças e/ou interesses econômicos e políticos.

\footnotetext{
${ }^{56}$ Contextualizando: A PANDEMIA que estamos vivenciando em relação ao Covid-19 certamente irá trazer mais elementos a essa discussão. Esperamos que mais sustentáveis!
} 
Em suma, considerando a incerteza dos desdobramentos nos fatos naturais e sociais que estão por vir, e a difusão de ideias e crenças que conduzem setores da sociedade para uma estranha "insustentabilidade justificada", observa-se que a natureza dos problemas (ou soluções) tente a tornar-se cada vez mais complexa. Revisemos (sempre) nossas práticas!

\section{CAMINHOS METODOLÓGICOS}

\subsection{Abordagem teórico-metodológica: do pragmatismo a novas perspectivas para análise das intervenções humanas}

Considerando que há um sentido utilitarista nas ações humanas e que essas se situam no tempo (seja no sentido cronológico, de projeção de uma relação casual ou de expectativa), o "homem pragmático" sente-se senhor do futuro (KORTE, 2001). Com relação a isso, e levando em conta os fins, os valores, os meios e a verdade científica, Dewey (1957 apud KORTE, 2001, p. 96), afirma que “[...] quem quer, de verdade, os fins, deve querer os meios e deve conhecê-los". Para Korte, 2004, p. 96, com relação às ações humanas, "Esse conjunto só é reconhecido ou revisto na medida em que se afina ou se opõe ao que pretende ou intenta fazer".

De uma maneira geral, o método pode ser entendido como um conjunto de elementos que instrumentaliza os procedimentos de como se fazer algo ou de como se obter o conhecimento efetivo daquilo que buscamos compreender (KORTE, 2001). Partindo dessa premissa, fundamentada na compreensão tanto do objeto como do processo de pesquisa e no rigor científico, tornou-se mais intuitiva a compreensão de que são vários os métodos que podem ser aplicados para elucidar o que desejamos conhecer ou a maneira de interpretar questões ambientais.

Sendo assim, realizou-se a tentativa de condução de um processo de pesquisa, que elucidasse tanto as propriedades do objeto estudado, como os aspectos da interpretação dos sujeitos que o pesquisaram. Para isso, articulou-se uma abordagem baseada na percepção dos sujeitos envolvidos, com a leitura e interpretação crítica de textos que compuseram uma literatura de referência ${ }^{57}$, os quais tratam dos temas: teoria crítica e emancipação social

\footnotetext{
${ }^{57}$ Textos sugeridos como referência pelo Professor Milton Ferreira da Silva Júnior, da Universidade Estadual de Santa Cruz/BA, no contexto da disciplina Meio Ambiente e Interdisciplinaridade do Curso de Doutorado em Desenvolvimento e Meio Ambiente da Associação Plena em Rede de Doutorado em Desenvolvimento e Meio Ambiente, no ano de 2014.
} 
(SOUZA SANTOS, 2007), metodologia e transdisciplinaridade (KORTE, 2001), complexidade e transdisciplinaridade (SOMMERMAN, 2005), comitês de pesquisa e bioética (WOLTMANN, 2006) e pesquisa-ação (TRIPP, 2005).

\subsection{Procedimentos e técnicas}

O grupo que realizou o processo de pesquisa em questão corresponde aos autores deste texto e é formado por profissionais de diferentes campos do conhecimento e áreas de formação, fato que potencializou a prática interdisciplinar. O que parece ser redundante, considerando-se que quem conduz o processo de pesquisa, em geral apresenta seus resultados, mas neste caso, encontra-se aqui enfatizado para reforçar o envolvimento sujeito-objeto.

No primeiro instante, evitou-se a prática da "divisão das atividades por partes", utilizando como estratégia a escolha, por cada um, de materiais que remetessem a uma questão ambiental relevante, sem a influência dos outros membros do grupo para que, posteriormente, em votação secreta, fossem escolhidos os dois materiais representativos para análise, sendo que cada um não poderia votar em sua própria seleção.

Com este procedimento simples, diversos temas emergiram, tais como: a importância da abertura diante das diversas opiniões, a fim de reforçar a interdependência das ações em grupo e a busca do que poderia ser comum na percepção das diferentes disciplinas, diante das questões ambientais, refletidas pela percepção de cada um. Após a votação, cada um escreveu uma síntese de uma página a respeito da sua percepção diante dos materiais selecionados, fundamentando-se na literatura de referência.

Nestas etapas, realizaram-se duas reuniões presenciais, contudo, o processo de seleção, votação e envio das sínteses foi viabilizado por meio da Internet. De posse das sínteses, foi realizada a leitura em grupo para identificação e análise dos conteúdos mais recorrentes, avaliação do processo e produção do texto final (Figura 1).

Para dar suporte à análise das sínteses, utilizou-se o aplicativo IRAMUTEQ $^{58}$ (Interface de R pourles Analyses Multidimensionnelles de Textes et de Questionnaires), por meio do qual foi possível elaborar uma "nuvem de palavras" - que agrupa e organiza as palavras graficamente a partir de sua frequência de ocorrência no texto - e uma "análise de

\footnotetext{
58“'O IRAMUTEQ é um software gratuito e desenvolvido sob a lógica da opensource, licenciado por GNU GPL (v2). Ele ancora-se no ambiente estatístico do software R e na linguagem python". (CAMARGO E JUSTO, 2013, p. 515).
} 
similitude", na qual verificam-se as ocorrências entre as palavras e são indicadas as suas conexidades.

A busca pela multidimensionalidade dos resultados teve como princípio a colaboração e foi mediada por um, ou alguns membros do grupo em cada momento, com a finalidade de garantir o rigor no processo de pesquisa e o cumprimento dos prazos estabelecidos.

Figura 1 - Diagrama do processo de pesquisa

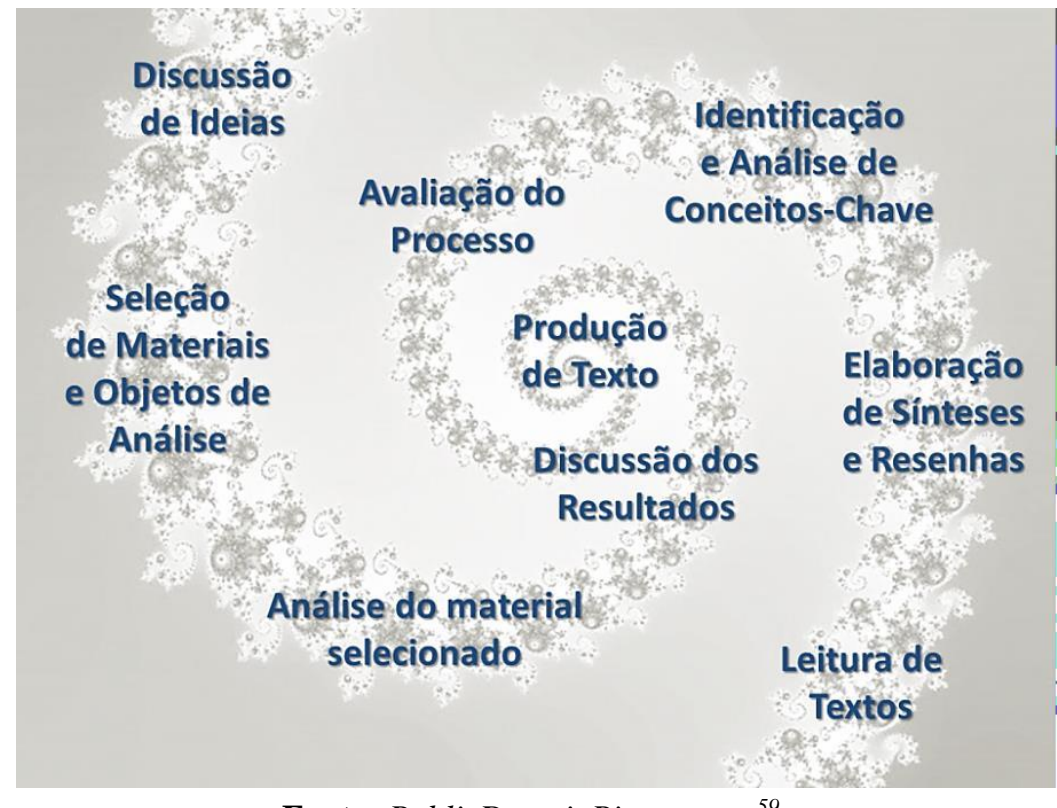

Fonte: PublicDomainPictures.net ${ }^{59}$.

\subsection{Materiais utilizados como objeto de análise}

Não houve especificação do tipo de material a ser indicado, então, foram apresentados para a seleção: duas charges, uma tirinha, duas matérias de revista em mídia impressa, uma matéria de revista em formato digital, seis vídeos, quatro frases/ pensamentos de autores diversos, uma frase elaborada por um dos membros do grupo, um questionamento elaborado por membro do grupo; uma foto panorâmica da Praia de Pipa/RN. Dentre eles, foram selecionados um vídeo, uma tirinha e 2 charges (Figura 2).

\footnotetext{
${ }^{59}$ Disponível em: https://www.publicdomainpictures.net/en/view-image.php?image=48679\&picture=modeladoespiral-fractal\&jazyk=PT. Acesso em: fev. 2020.
} 
Figura 2 - Materiais selecionados

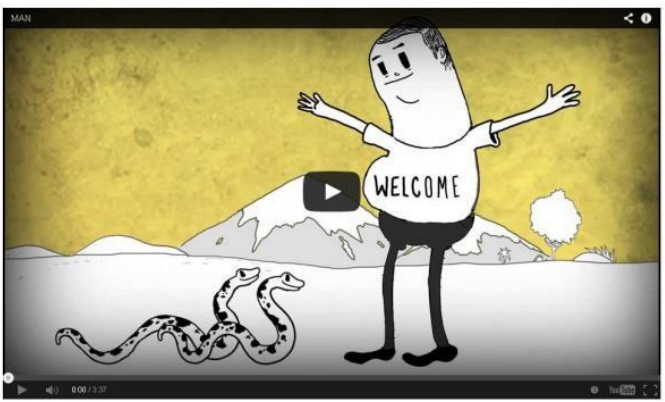

Autor: Steve Cutts. Copyright ( $) 2012$ www.stevecutts.com ${ }^{60}$.

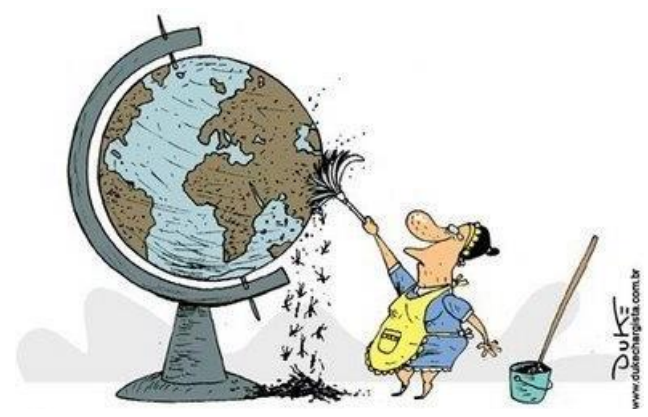

Autor: Duke. ${ }^{61}$

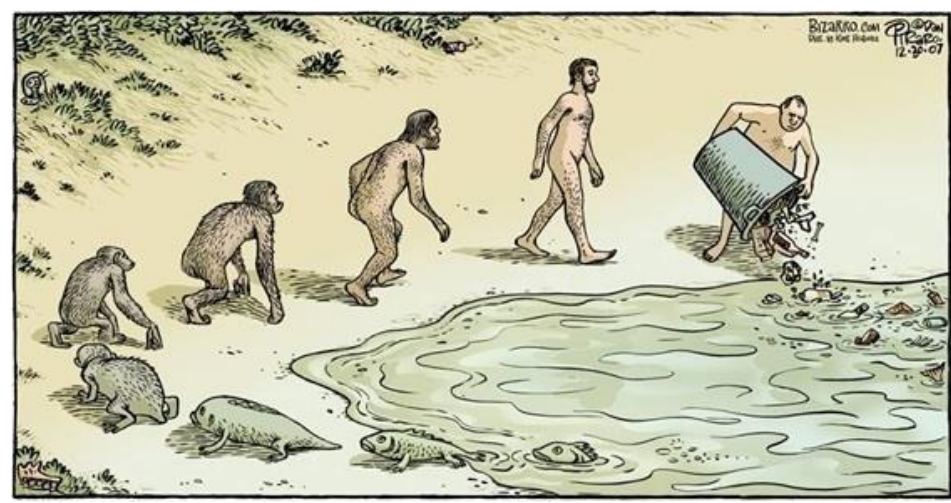

Autor: Dan Piraro, 30/12/2007 ${ }^{62}$.

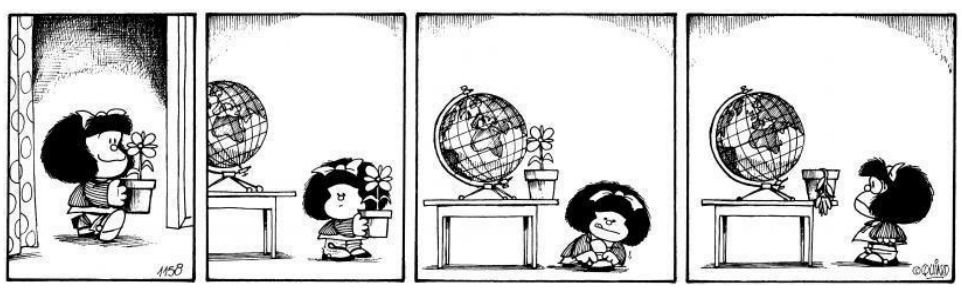

Autor: Quino ${ }^{63}$.

Fonte: buscas na rede mundial de computadores, 2014.

Além do vídeo e ilustrações, como forma de dar suporte à elaboração das sínteses, definiu-se quais os principais elementos conceituais norteadores para a reflexão (Quadro 1).

\footnotetext{
${ }^{60}$ Disponível em: http://www.youtube.com/watch?v=WfGMYdalClU\&feature=kp. Acesso em 22 abr. 2014.

${ }^{61}$ Disponível em: http://miriamsalles.info/wp/archives/588. Acesso em: 22 abr. 2014.

${ }^{62}$ Disponível em: http://situationplanetaire.blogspot.com.br/2012/08/ajustements.html. Acesso em: 22 abr. 2014.

${ }^{63}$ Disponível em: http://espanol-comfenalco.blogspot.com.br/2011/06/leamos-y-analicemos-historietas-

8_03.html. Acesso em: 22 abr. 2014.
} 
Quadro 1 - Elementos conceituais utilizados para discussão

\begin{tabular}{|c|c|}
\hline Transdisciplinaridade & $\begin{array}{l}\text { Tentativa de construção de uma conceituação multidimensional, } \\
\text { considerando vários níveis de realidade. A vida existe na relação com o } \\
\text { meio ambiente, com o todo. Está "entre", "através" e "além" das } \\
\text { disciplinas (BASARABNICOLESCU, 1999), transgride as fronteiras } \\
\text { epistemológicas de cada ciência disciplinar e constrói um novo } \\
\text { conhecimento "através" das ciências, um conhecimento integrado em } \\
\text { função da humanidade, resgatando as relações de interdependência, pois } \\
\text { a vida se constitui nas relações mantidas pelo indivíduo com o meio } \\
\text { ambiente. É a dissolução dos discursos homogeneizantes na ciência e na } \\
\text { cultura. }\end{array}$ \\
\hline Interdependência & A interdependência é um princípio que sustenta a vida nesse planeta. \\
\hline $\begin{array}{c}\text { Lógica do Terceiro } \\
\text { Incluído }\end{array}$ & $\begin{array}{l}\text { Esta lógica não abole a lógica aristotélica do "sim” e do "não”. Apenas } \\
\text { não mais se considera a existência de somente dois termos e, sim, três; um } \\
\text { terceiro que é o Terceiro Termo Incluído. A lógica do Terceiro Termo } \\
\text { Incluído permite cruzamento de diferentes olhares, construindo-se um } \\
\text { sistema coerente e sempre aberto, o que nos permite compreender, } \\
\text { principalmente, os fenômenos sociais e políticos. }\end{array}$ \\
\hline $\begin{array}{l}\text { Diálogo } \\
\text { Tolerância } \\
\text { Abertura } \\
\text { Respeito } \\
\text { Ética }\end{array}$ & $\begin{array}{l}\text { O diálogo entre os estudiosos constitui uma prática necessária ante a } \\
\text { deterioração do mundo sob o domínio da fragmentação e objetividade do } \\
\text { conhecimento que omite e desencanta a vida. O compartilhamento } \\
\text { universal do conhecimento não poderá ocorrer sem a autotransformação } \\
\text { apoiada no sentimento de tolerância e abertura. No diálogo, a tolerância } \\
\text { é o reconhecimento do direito às ideias e verdades contrárias às nossas } \\
\text { (art.14 da Carta da Transdisciplinaridade, Convento de Arrábia, } \\
\text { Portugal, } 2 \text { a } 6 \text { de novembro de 1994). Tolerância e abertura são duas } \\
\text { atitudes imprescindíveis no diálogo entre os diferentes saberes, as } \\
\text { diferentes culturas, as diferentes teorias e os diferentes modos individuais } \\
\text { de ser. }\end{array}$ \\
\hline
\end{tabular}

Fonte: Trechos selecionados de SANTOS (2005).

\section{RESULTADOS E DISCUSSÃO: SÍNTESES DA PERCEPÇÃO COLETIVA}

Observou-se que o material selecionado, tem foco no modelo de desenvolvimento adotado pelos seres humanos e seus costumes, nos quais, ocorre a separação do indivíduo observador e usuário de recursos naturais, do objeto observado e explorado, ou seja, de um lado está a natureza e do outro a sociedade (ou o ser humano) que a degrada em prol de seus objetivos.

Em análise das sínteses geradas, viu-se que as maiores recorrências na percepção individual, dizem respeito à forma como o ser humano usa e interage com a natureza, bem como as novas possibilidades para estudar o ambiente e as possibilidades de novas formas de conhecimento. Na nuvem de palavras e gráfico de similitude (Figuras 3 e 4), pode ser 
observado o resultado da percepção coletiva, a qual segue na forma dos dois tópicos discutidos a seguir. No primeiro tópico, evidenciam-se as percepções que tiveram foco direcionado ao material selecionado, no segundo, as percepções com maior aporte da literatura de referência ou complementar.

Figura 3 - Nuvem de palavras

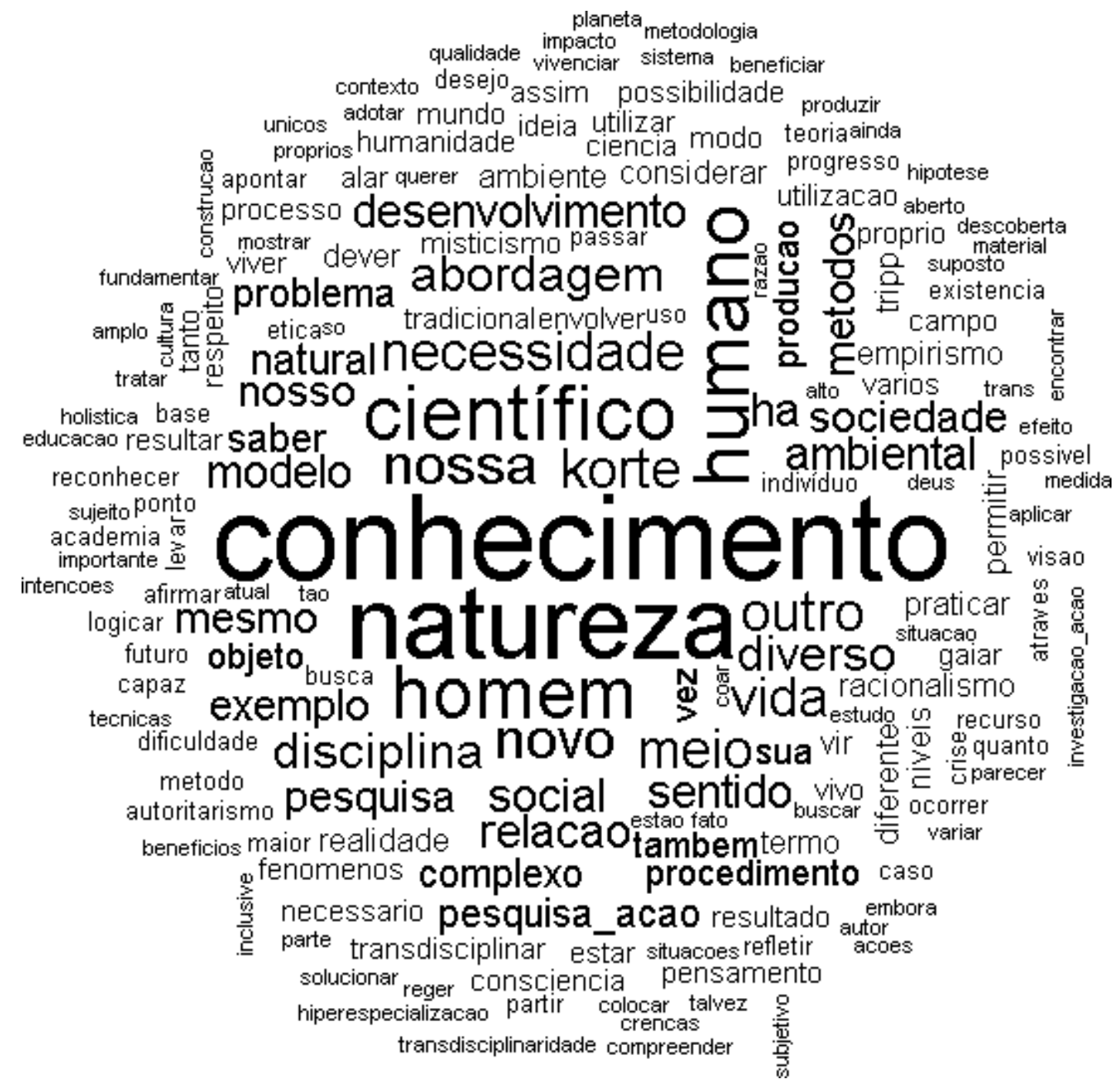

Fonte: organização dos autores, 2014.

A nuvem indica uma preocupação recorrente com o "conhecimento" em suas diversas formas, mas com ênfase no "científico", e suas possibilidades como agente na melhoria das relações entre a "natureza", que também se evidencia, e o "homem" ou o "humano". Palavras como “disciplina”, “abordagem”, "pesquisa”, "procedimento”, "pesquisa-ação”, "métodos”, 
"objeto", "modelo", "outro" e "necessidade", acentuam a preocupação não só com o conhecimento, mas com sua "produção".

Também transparece o tema do "desenvolvimento", que se articula com a "sociedade" o "ambiental" e "relação social". Palavras como "complexo", "meio" e "sentido", "nosso" e "saber", refletem a busca por novas formas de busca por compreensão, nas quais, a subjetividade penetra. As palavras que aparecem com menor frequência, acentuam estas percepções evidenciadas. Dentre a literatura de referência, KORTE (2001; 2004), foi o autor mais citado, como se observa nas ilustrações acima. Acredita-se que isto se deveu tanto à extensão do material, como pela forma que o autor apresenta suas ideias.

Figura 4 - Gráfico de similitude

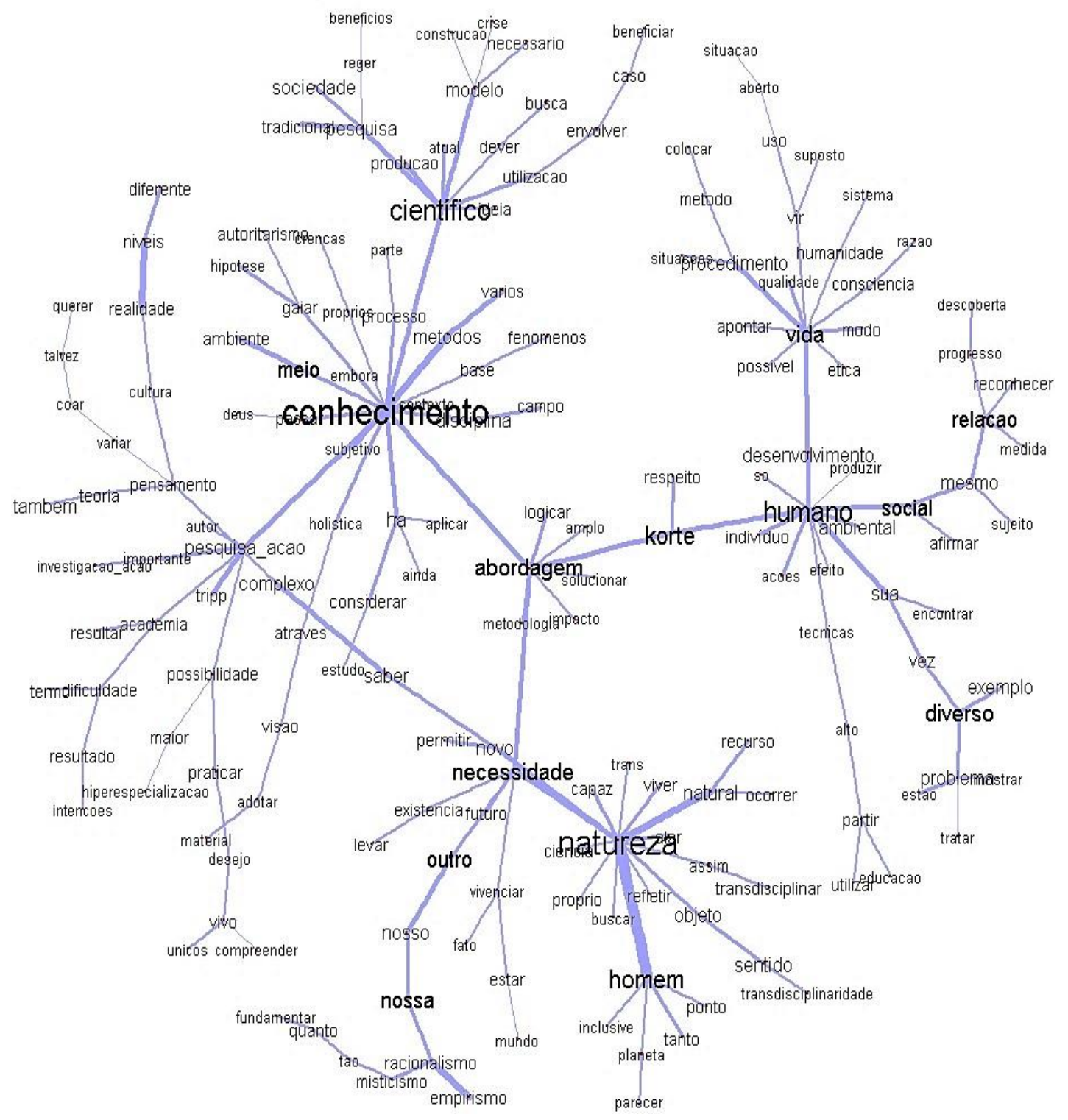

Fonte: organização dos autores, 2014. 
No gráfico que representa a análise da similitude, observa-se que a conexão mais forte encontra-se entre "natureza" e "homem". Dentre outras conexões possíveis, destaca-se "homem", "natureza”, "buscar”, "refletir", "necessidade”, "novo", "metodologia”, "abordagem", “amplo", “conhecimento", "científico". No texto que segue, encontram-se as inúmeras possibilidades de relações, que reforçam a interdependência dos termos.

\subsection{O sentido utilitarista das ações humanas: o desequilíbrio dos fatos e as novas possibilidades de compreensão}

Vivemos uma época em que, paradoxalmente, na medida em que avançamos com novas descobertas e progressos científicos extraordinários, retrocedemos em nossa relação com a natureza. Consumimos nossos recursos naturais como se fossem infinitos, provocamos injustiças e segregação socioespacial como se fosse possível uma convivência harmônica em tal situação. O atual estágio de degradação socioambiental que impera em nosso planeta parece apontar para uma incompatibilidade entre avanço cientifico e conservação das condições socioambientais indispensáveis para a qualidade de vida da humanidade.

Segundo Capra (1997), o objetivo da ciência passou a ser aquele conhecimento que pode ser usado para dominar e controlar a natureza e, hoje, ciência e tecnologia buscam fins profundamente antiecológicos. Desta forma, é importante questionarmos até que ponto a produção cientifica nas universidades tem contribuído com uma relação sociedade-natureza que tenha como foco a qualidade de vida da humanidade?

Ao se realizar uma leitura sobre a atual conjuntura da sociedade humana nos deparamos com uma situação aparentemente antagônica entre o desenvolvimento econômico, científico e tecnológico e o desenvolvimento social, humano e também ambiental: Todo esse desenvolvimento perpassa pela utilização e apropriação que o ser humano passa a fazer da natureza na qual se encontra inserido.

O desenvolvimento da humanidade teve como base a manipulação da natureza, e desde então o homem foi aprimorando essa manipulação e tornando-a cada vez mais refinada, com isso foi utilizando a natureza para beneficio próprio, extraindo dela as fontes essenciais para sua manutenção e para produção de artefatos que melhorassem a qualidade de vida.

Desde então, o homem vem impondo sua "superioridade" sobre a natureza e transformando-a para além da sua necessidade, o que vem causando o surgimento de diversos problemas, em várias esferas, desde problemas com cunho social, até mesmo econômico e 
ambiental. A soberania do homem é imposta, através do "sistema", a classes inferiores e ao ambiente em que vive, isso pode ser visto no material utilizado como ponto inicial da construção desse pensamento, onde vemos o homem transformando a natureza e modificando as características naturais, transformando tudo em um monte acumulado de objetos sem sentido, que vão perdendo a função pela qual foi criado e ficando esquecido, mas tornando-se assim mais um poluente para o planeta.

Além dessas conversões da natureza para objetos, também vemos o uso da natureza no seu sentido estrito, seja como fonte natural de recurso ou na forma de alimento, sendo modificada, para atender a demanda crescente da população, cujo número vem aumentando de forma a tornar-se insustentável, e ai se torna necessário a veiculação industrial dos alimentos (que aqui irei incluir o uso dos agrotóxicos e o consumo de hormônios animais), é notória a intervenção do homem na natureza, alterando inclusive os ciclos naturais.

Segundo Sommerman (2005), nenhum ser vivo pode viver sem seu ecossistema, sem seu meio ambiente e não podemos compreender alguma coisa de modo autônomo, se não compreendendo aquilo de que ele é dependente. Este modelo de desenvolvimento coloca em pauta os meios da "evolução" do homem, sua forma de gerar produtos e riqueza, sua consciência individual e coletiva, bem como a persistente degradação do ambiente. No caso do vídeo "MAN", observa-se inclusive a estranha satisfação do ser humano diante dos impactos de suas ações destrutivas, sentando-se como um "rei", em todo o lixo gerado por ele mesmo.

A atitude humana se apresenta nos materiais, que possuem em comum uma mensagem, de que o modelo de uso e ocupação adotado pelos seres humanos resultou na perda de uma visão integrada e no distanciamento da sua posição como espécie interdependente das outras e dos elementos inanimados que compõem o planeta. A partir daí, os seres humanos tornam-se capazes de destruir e desequilibrar a natureza modificando suas relações enquanto sujeito, sendo inclusive necessário, que sejam "espanados” do planeta.

Para satisfazer suas "necessidades", que são cada vez maiores e com as mais diversas finalidades, as pessoas vêm fazendo uso de recursos, técnicas e procedimentos de modo cada vez menos consciente. Nas ciências da vida, por exemplo, diversas são as situações que remetem à consciência dos cientistas, à sua ética pessoal e profissional.

Do ponto de vista de uma atividade científica pautada na fragmentação do saber ou na hiperespecialização, reduz-se a complexidade destes fenômenos, objetos e sistemas relativos às ações predatórias, desencadeando perdas para a humanidade no sentido que a geração de 
conhecimentos pode (e deve) contribuir sobremaneira na diminuição dessas ações, tanto quanto mais, considere esta complexidade e relevância subjetiva e objetiva.

No momento em que se evidencia a crítica com respeito ao fechamento na condução das disciplinas e pesquisas sobre o ambiente, ocorre a emergência da razão complexa, a qual pode ser capaz de retomar e estabelecer um novo diálogo entre as disciplinas e saberes em prol de uma nova consciência que permita o reencontro entre homem e a natureza. A inserção de mais níveis de realidade nas abordagens e métodos da ciência, tais como o nível do misticismo, do intuicionismo e da amorosidade (relativa à natureza do respeito e aos padrões éticos),permite a geração de muitas possibilidades de intervenções teóricas e práticas (NICOLESCO, 2005; KORTE, 2001).

O pensamento complexo sugere a articulação de várias teorias, abordagens e metodologias pluri, inter ou até transdisciplinares, a fim de tecer formas de unir o que antes fora separado. Esta forma de pensar permite a quebra de barreiras, feudos, estruturas fechadas, bloqueios do saber, reduções no olhar, fragmentações do ser, potencializadas pelo predomínio da disciplinaridade.

Nesse sentido, o pensamento complexo sugere alternativas para unir não só os saberes disciplinares, mas as diferentes culturas, os diferentes níveis do sujeito e seu ambiente. Para Sommerman (2005), nem mesmo a complexidade ampliada é capaz de dialogar com as outras culturas, e para que seja alcançada há a necessidade de reencantar a educação para estreitar e planificar a realidade, sendo indispensável para isto, o advento da multidimensionalidade.

Outro ponto essencial trata-se da ética humana, a qual deve acompanhar os cientistas na busca pelo progresso, uma vez que suas descobertas, e os procedimentos que permitem tais descobertas, produzem efeitos que refletirão de modo positivo ou negativo na sociedade como um todo, e na vida de cada indivíduo.

Há muito a se discutir sobre as questões éticas nas pesquisas científicas, pois em muitos casos pensa-se no benefício da sociedade como um todo, mas não se considera prejuízos causados em nível individual. Em procedimentos que envolvem a utilização de cobaias humanas, por exemplo, pessoas são consideradas como verdadeiros objetos de estudo, arriscando a própria vida, em alguns casos, para que haja o desenvolvimento científico em sua última instância e, assim, sendo os resultados positivos, a sociedade seja beneficiada.

Além desse exemplo, diversas outras situações podem ser citadas como "tabus" bioéticos discutidos há décadas, como o caso da eutanásia, do aborto, das pesquisas envolvendo células tronco embrionárias, entre outras. Essas situações ainda não apresentam 
um discurso convincente que nos permitam dizer que os benefícios de tais procedimentos sobrepõem-se aos seus malefícios. Afinal, quais são os benefícios que se sobrepõem à vida humana ou de qualquer outro ser vivente?

Desse modo, observa-se a necessidade de que as pessoas reflitam sobre suas atitudes cada vez menos conscientes, que visam o desenvolvimento imediato em detrimento da vida e da responsabilidade ambiental. Somente quando for possível tal reflexão, e se enxergue seus resultados reais, poderemos nos desenvolver de forma harmônica, como ocorre com o ritmo da vida natural, em equilíbrio dinâmico.

Transpassando as visões a respeito da bioética, assim como dito por Woltmann (2006), na busca incessante pelo reconhecimento (do homem pelo homem), nota-se a super exploração tanto da natureza como do próprio homem. Para esta autora, o homem esquece o respeito mútuo e na busca exacerbada pelo bem estar momentâneo, ultrapassa as regras éticas e morais que devem reger a sociedade.

Estes fatos, a forma como lidar com eles no cotidiano e de como analisá-los, devem nos conduzir a repensar tais problemas, visto que são determinantes nas relações entre os homens e nas suas relações com a natureza, ao ponto de imaginar-se equivocadamente, que a cura para o planeta só seria possível com a retirada dos seres humanos.

\subsection{Percorrendo as vias da complexidade e transdisciplinaridade}

\section{A abordagem transdisciplinar}

A fim de lidar com a complexidade dos impactos socioambientais, formas de abordagem que aglutinam uma maior quantidade de possibilidades de análise, níveis de realidade, integração de profissionais em diferentes setores e áreas de estudo, se fortalecem em contraponto à hiperespecialização. Morin (2003, p. 13), afirma que a “[...] a hiperespecialização impede de ver o global (que ela fragmenta em parcelas), bem como o essencial (que ela dilui)".

Estas abordagens incluem tanto noções mais abertas diante das difíceis questões a solucionar no amplo e interconectado espectro dos fenômenos ambientais, como por exemplo, o uso da noção do terceiro incluído (NICOLESCU, 2005). Além disso, elas têm proporcionado o retorno de noções que se diluíram na ciência moderna, tais como a necessidade de um rigor não necessariamente pautado na lógica matemática ou em 
abordagens de natureza cartesiana (da causa e efeito ou dualística), da valorização da autocrítica, da responsabilidade social e da recuperação dos valores do pesquisador na atividade científica (LACEY, 2008, 2011).

Considerando os vários caminhos para o conhecimento, $\operatorname{KORTE}$ (2001, p.16) contextualiza que,

Há métodos unidisciplinares específicos, aplicados a disciplinas específicas. Há métodos interdisciplinares que propiciam o conhecimento via de abordagem por diferentes disciplinas. Há métodos pluri e multidisciplinares, cujos trajetos são determinados por informações oriundas de várias diferentes disciplinas.

Korte (2001) justifica essa variação de métodos pela ocorrência de crenças diversificadas e pelo fato de elas relacionarem-se em vários campos do conhecimento e em níveis diferentes de realidade e afirma que há o "método transdisciplinar".

Nicolescu (apud CUNHA, 2003) define o método transdisciplinar como a "transgressão das fronteiras entre as disciplinas", seu significado vai além daquilo que é próprio das disciplinas. A esse respeito KORTE (2001, p. 36) é enfático:

Transdisciplinar é a metodologia mediante a qual, utilizando-se a inter, a multi e a pluridisciplinaridade, as informações e os resultados da combinação de informações e metodologias ultrapassam o campo próprio de cada disciplina, excedendo o quadro das abordagens metodológicas próprias de cada um. [...] Vê-se que a combinação dos métodos designados por misticismo, autoritarismo, racionalismo, empirismo, pragmatismo, ceticismo, amorosidade e intuicionismo excede os campos específicos de cada uma das disciplinas estudadas pelo ser humano.

Silva (2000) diferencia o sistema "interdisciplinar" do "transdisciplinar" e afirma que na interdisciplinaridade há dois níveis e objetivos múltiplos, a cooperação procede de um nível considerado superior; na transdisciplinaridade há um sistema de níveis e objetivos múltiplos e a coordenação ocorre com vistas a uma finalidade comum dos sistemas envolvidos.

Ainda segundo o mesmo autor, no plano interdisciplinar ocorre a integração dos domínios linguísticos de cada disciplina e "Essa integração é permitida, facilitada e orientada pela existência de uma temática comum a todas as disciplinas, com a qual elas deverão observar o objeto" (Silva, 2000, p. 76) e, como resultado, existiria um produto final refletindo cada parte da realidade e em cada uma dessas partes percebe-se a interpenetração linguística das diferentes disciplinas. 
No plano transdisciplinar o que muda é a construção de um único domínio linguístico, que só é possível com "[...] a identificação de zonas de não resistência epistêmica entre as disciplinas e foco dado pela temática, com o qual se faz, então, a observação do objeto" (Silva, 2000, p. 76). Do ponto de vista do resultado desse modo de produção, tem-se um único texto capaz de refletir a multidimensionalidade da realidade. Apesar de a interdisciplinaridade também exigir a cooperação e a coordenação entre as disciplinas, na transdisciplinaridade, existe o objetivo de transcendê-las (SILVA, 2000).

Portanto, esse procedimento transdisciplinar nos dá a ideia da necessidade de uma mudança na abordagem do saber científico, acreditando-se assim que o tratamento dos saberes complexos seja mais bem tratado com o apoio da articulação de outras lógicas do conhecimento. Para esse contexto, a abordagem metodológica pode ser realizada de forma em que os vários conhecimentos sejam aceitos, na busca de uma visão holística para decifrar problemas complexos, sem a fragmentação adotada por métodos reconhecidamente criticados na contemporaneidade.

\section{O holismo e as possibilidades alternativas de conhecimento}

Os caminhos já abertos para o conhecimento podem nos confundir, o que nos faz aventurar por caminhos, inclusive no tempo, que nos parecem originais e mais próprios. A insuficiência de viajar pelo tempo, pode dar às crenças características pessoais e subjetivas, místicas. Reconhecer a natureza, no sentido de conhecer de novo, significa buscar o que de alguma forma está codificado em nossa memória, tal como se fala em "memória genética". Como consequência, vem a nossa mente as "ruínas da Torre de Babel", ou seja, pontos da existência de uma suposta linguagem comum fundamental, perdida ao longo de evoluções e involuções sugeridas pela história da civilização.

Embora subjetivo, o conhecimento assimilado pelo misticismo, ou ao Sagrado, pode ter a mesma validade que o alcançado pelos demais métodos de conhecimento. Segundo Pepperel-Montague (1944) apud Korte (2004) o misticismo é a teoria que sustenta que a verdade pode ser alcançada por certa faculdade de intuição, superior a nossa razão e sentidos. Paradoxalmente, podemos encontrar nas nossas incertezas, explicações tão misteriosas fundamentadas no racionalismo quanto no próprio misticismo envolvido, tal como fez Erich Von Däniken, nas suas conclusões fictícias de acordo com a crítica, em "Eram os Deuses 
Astronautas?" de 1968. Em contrapartida respeitar e venerar o Sagrado, como estratégia de lidar com conflitos entre os níveis de realidade, exige postura plenamente transdisciplinar.

Foi nesta ótica que um expressivo exemplo de cognição, a "Hipótese de Gaia", ao longo do tempo, transcendeu os níveis de conhecimento sobre a forma prístina de se entender profundamente a dinâmica do meio ambiente. A evolução do conhecimento sobre "Gaia" passa pela "religião primordial” no paleolítico (DUARTE; 2008 apud BEZERRA; 2010), no culto à deusa mãe do paganismo, desdobrando-se para as civilizações antigas, onde o poder absoluto dos deuses vivos mostra que as raízes místicas dão base ao autoritarismo - com todos os inconvenientes sociais, bem como as vantagens que o caracterizam, tal como quando encurta as distâncias para se chegar ao conhecimento.

A "Hipótese de Gaia", em contraposição ao autoritarismo, passou também por uma fase de autoridade moral, um dos gêneros da ética e padrões norteadores nos caminhos do conhecimento, para por fim, ser apoiada no cientificismo e na experimentação para ser reconhecida amplamente.

Embora com este exemplo estejamos vivenciando que a temporalidade é contingencial nos processos cognitivos, para uma compreensão holística de fato, em uma determinada etapa da construção do conhecimento, há necessidade de uma abordagem atemporal. O holismo é o objetivo maior da transdisciplinaridade (Pierre WEIL; 1993 apud Korte; 2004) e na medida em que responde às formas de percepção sensitiva, o holismo inclui-se no empirismo metodológico, válido quando se busca o entendimento puro, porém, somente aos objetos dos sentidos. Logo, de certa forma o conhecimento holístico pode também ser-nos propiciado pelos métodos do racionalismo e do empirismo, como ocorreu na "Teoria de Gaia".

Em síntese, empiristas são os que aceitam a dominância do concreto sensível sobre as abstrações e, racionalistas, os que acreditam que as abstrações, quando logicamente ordenadas, têm prevalência sobre o que nos é aportado pelas percepções do concreto sensível. Nas condições da sociedade atual, na qual racionalismo e empirismo, às vezes por caminhos distintos, se cruzam e se entrelaçam, supostas verdades sobre as quais nós fundamentamos e justificamos as nossas crenças científicas são corroboradas. Vivemos talvez o mais alto momento das aptidões técnicas, com o avanço tecnológico e científico nos últimos dois séculos, possibilitado pelos incrementos na racionalização e sistematização de observações e informações. Nem autoritarismo nem misticismo, por si sós ou combinados, produziram um corpo de (supostas) verdades tão sólido, coerente e extenso como o que resultou da conjunção metodológica entre empirismo e racionalismo. 
Um exemplo prático é quando refletimos sobre as alterações ambientais constatadas atualmente (empirismo), entendemos que somos os únicos seres vivos em que os desejos prevalecem sobre necessidade (racionalismo) e segundo a "Hipótese de Gaia" vamos sucumbir em nossas próprias necessidades, não só nos, mas a biota em si, em função dos desejos de poucos - ser humano - e a obrigação é de muitos - biota. As alterações ambientais são fruto dos nossos desejos, destituídos de ética, postos em prática, e de fato, talvez sejamos os únicos seres vivos a poder fazer isso, ou os outros, não sabem ou não querem fazê-lo.

A humanidade progride, mas em apenas em segmentos da sua existência, em grande parte, devido à organicidade de seus sistemas no aproveitamento das estruturas sociais e coletivas. O processo de conhecimento exige a participação de outro ou outros, caso contrário, a tomada de consciência traduz-se por experiência subjetiva, mas não pode ser designada conhecimento, já que não teve a participação de outrem. O mais alto momento das aptidões técnicas e da inteligência humana será tão útil para sobrevivermos em equilíbrio com o nosso meio, quanto maior existir um conhecimento vivenciado de fato com os semelhantes (LOVELOCK, 2006).

\section{Em busca de ressignificar a natureza e o homem}

A ideia da separatividade fez com que chegássemos ao século XXI com problemas sociais, humanos, éticos e institucionais, envoltos em avanços tecnológicos, contrastes e diversidades. Cresce a desumanização da história e a devastação da natureza em escala planetária. Nossa semelhança genética com outros seres, como os primatas, revela nosso enraizamento na vida. Isso pode ser motivo de crise na ilusão egóica de domínio sobre a Terra, acarretando em um modelo de civilização que desumaniza o homem e desnatura a natureza.

O homem, produto da natureza biofísica e cósmica, segundo Santos (2005) carrega consigo atitude transdisciplinar desde a sua origem. No entanto, as bruscas transformações do meio natural, as rupturas, as fragmentações, otimizadas pelos anseios desenfreados, pôs fim a essa irmandade cósmica.

Morin (2011) enfatiza que, trazemos, dentro de nós, o mundo físico, o mundo químico, o mundo vivo, e, ao mesmo tempo, deles estamos separados por nosso pensamento, nossa consciência, nossa cultura. 
A crise ambiental ao qual estamos submetidos é uma crise de conhecimento e de formas de conhecimento. Neste sentido, a transdisciplinaridade, surge como uma forma de reintroduzir a ideia de que todos os seres são complexos e interdependentes. Korte (2004), afirma que a partir de posturas transdisciplinares podemos utilizar diversos conceitos, números e leis que regem as ciências para dar significado ao comportamento humano e social. Como, por exemplo, o conceito de átomo está associado ao indivíduo.

Isto nos leva a crer que não há indivíduos isolados no contexto social, nem tampouco, no meio natural. Um novo olhar diante da natureza e da existência humana requer que sejamos capazes de perceber o mundo em suas múltiplas dimensões e interações.

Apesar disso, a crise também nos leva a gestar novas práticas e novas teorias; a necessidade de sobreviver, nos permite desenvolver novos campos de possibilidades: de pensamento, de aprendizagem e de existência. Diante do quadro caótico que estamos vivenciando urge a necessidade de ressignificar a natureza, este processo constitui acima de tudo, aprender a viver humanamente.

\section{CONSIDERAÇÕES FINAIS}

Houve uma tentativa com o presente trabalho de exercitar a interdisciplinaridade. Entretanto, pode-se presumir um caráter transdisciplinar, uma vez que houve a intenção, através de uma linguagem unificada e sem resistência epistêmica de interligar os diversos pontos abordados.

Em função das características diversificadas dos componentes do grupo, alguns membros não entenderam inicialmente, ou tiveram resistências à aceitação da proposta, que foram dirimindo-se ao logo do processo. Não houve uniformidade no processo executado, seja pelo cumprimento de prazos ou pela expressão de opiniões não acontecer da forma acordada.

Logo, conclui-se, que em um trabalho no qual ocorra uma necessidade de maior envolvimento de um grupo para gerar resultados nessa perspectiva de não fragmentação, deve-se dispor de um bom arsenal de estratégias para promover o diálogo, e lidar com um nível de comprometimento e interesse variáveis, os quais também são dependentes da etapa que está sendo realizada.

Enquanto alguns membros discorreram livremente sobre os materiais selecionados para análise, a partir de sua experiência diante do tema, para outros houve a necessidade do 
uso do recurso da "autoridade", refletido no uso de muitas citações da literatura de referência. Esta prática deixa transparecer o modo como se convencionou realizar os trabalhos científicos na academia. As especificidades do atual modo de formação acadêmica obriga a utilização das citações com frequência, o que de certa forma dá mais segurança ao seu produto, tornando-o "referenciado". Na busca pelo trânsito por conteúdos de outras áreas, a vivência do exercício crítico restrito a áreas específicas, provoca naturalmente a busca de autoridades nos assuntos para discorrer sobre os diversos temas do conhecimento.

As duas formas de leitura do objeto, quando articuladas, potencializam novas formas de conhecimento, pela coexistência de um conhecimento de natureza mais intuitiva, com a prática da busca pelos "referenciais". Viu-se que em ambos os casos as contribuições foram satisfatórias e complementares.

Uma vez que a intenção no estudo foi promover um exercício que permeasse temas como a complexidade, interdisciplinaridade e transdisciplinaridade viu-se que as diversas abordagens conjecturadas só foram possíveis com a leitura e busca de literatura diversificada. Reconhece-se que a maioria das visões sobre esses temas pode ser superficial no conhecimento vivenciado pelos estudantes e pesquisadores. Essa dificuldade é acentuada dependendo da formação acadêmica, mas, sobretudo, pela motivação subjetiva de cada um em abrir-se a novas possibilidades de conhecimentos e de procedimentos metodológicos, atitudes imprescindíveis diante das questões ambientais.

\section{REFERÊNCIAS}

BEZERRA, Karina Oliveira. Conhecendo a Wicca: princípios básicos e gerais. PANORAMA DE EXPERIÊNCIAS DO SAGRADO, UNICAP v. 1, n. 2, 2010.

CAMARGO, Brigido Vizeue; JUSTO, Ana Maria. IRAMUTEQ: um software gratuito para análisede dados textuais. Temas psicol. [online]. 2013, vol.21, n.2, pp. 513-518. ISSN 1413389X. Disponível em: http://dx.doi.org/10.9788/TP2013.2-16. Acesso em: mai. 2014.

CAPRA, Fritjof. O ponto de mutação. Trad. Álvaro Cabral. São Paulo: Cultrix, 2001.

CUNHA, Sheila Santos. O manifesto da transdiciplinaridade, por BasarabNicolescu: um breve resumo. Salvador/Dez/2003.Disponível em: http://www.ia.ufrrj.br/ppgea/conteudo/T24SF/Akiko/10-MANIFESTO\%20DA\%20TRANSDISCIPLINARIDADE.pdf. Acesso em: abr. 2014.

KORTE, Gustavo. Metodologia e Transdisciplinaridade. São Paulo, 2004. Disponível em: <http://www.ufrrj.br/leptrans/arquivos/korte.pdf>. Acesso em: abr. 2014. 
KORTE, Gustavo. Metodologia e Transdisciplinaridade. Ibiúna, São Paulo, 2001.

Disponível em:

http://gustavokorte.com.br/publicacoes/Metodologia\%20e\%20transdisciplinaridade\%2019.pd

f. Acesso em: abr. 2014.

LACEY, Hugh. Ciência, respeito à natureza e bem-estar humano. Sci. stud. [online]. 2008, vol.6, n.3, pp. 297-327.ISSN 1678-3166. Disponível em:

http://www.scielo.br/pdf/ss/v6n3/v6n3a02.pdf. Acesso em: 05 abr. 2014.

A imparcialidade da ciência e as responsabilidades dos cientistas. Sci. stud. [online].

2011, v.9, n.3, p. 487-500. Disponível em: <http://dx.doi.org/10.1590/S1678-

31662011000300003>. Acesso em: 05 abr. 2014.

LOVELOCK, James. A Vingança de Gaia. Rio de Janeiro: Intrínseca, 2006.

MORIN, Edgar. A cabeça bem-feita: repensar a reforma, reformar o pensamento. 8. ed. Rio de Janeiro: Editora Bertrand Brasil, 2003. 128 p.

NICOLESCU, Basarab. O manifesto da transdisciplinaridade. 3. ed. São Paulo: TRIOM, 2005. $165 \mathrm{p}$.

SANTOS, Akiko. O que é transdisciplinaridade. Rural Semanal. Universidade Federal Rural do Rio de Janeiro. 22/28 Ago. 2005. Disponível em:

http://www.ufrrj.br/leptrans/arquivos/O_QUE_e_TRANSDISCIPLINARIDADE.pdf. Acesso em: 10 abr. 2014.

SILVA, Daniel José da. O Paradigma Transdisciplinar: uma Perspectiva Metodológica para a Pesquisa Ambiental. In: Philippi Jr., Arlindo; C. E. M. Tucci, D. J. Hogan, R. Navegantes

(Orgs.). Interdisciplinaridade em Ciências Ambientais. São Paulo: SignusEditora,2000.

Disponível em:

http://www.dominiopublico.gov.br/pesquisa/DetalheObraForm.do?select_action=\&co_obra=5 0281. Acesso em: mar. 2014.

SOUZA SANTOS. Renovar a teoria crítica e reinventar a emancipação social. São Paulo: Boitempo, 2007.

WOLTMANN, A. Comitês de ética em pesquisa no âmbito Latino-Americano (BrasilArgentina): Transdisciplinaridade em prol da dignidade humana. Dissertação de Metrado (Universidade Federal de Santa Maria, Centro de Ciências Sociais e Humanas), 2006.Disponível em:

http://www.educadores.diaadia.pr.gov.br/arquivos/File/2010/artigos_teses/Biologia/Dissertac ao/comite_etica.pdf. Acesso em: mar. 2014. 


\section{$\infty$ ELO TRÊS}

\section{Manuela Maria Pereira do Nascimento}

Espontaneamente, considerando a ampla diversidade de propósitos dos seres humanos, notam-se tendências de reaproximação e afastamento entre sociedade e natureza. Apesar da constante busca por causas e efeitos das ações humanas sobre seu meio, já se reconhece que as variantes dos fenômenos naturais e/ou sociais são embutidas de incertezas e indeterminações, e a partir disso, é comum perguntar: $\mathrm{O}$ que se deseja? O que se pratica? $\mathrm{O}$ que é possível compreender? ${ }^{64}$

Nas limitações do conhecido, vislumbra-se o caminho da precaução e da ponderação, que pode ser mediado ora por motivações mais altruísticas, como a legítima preservação da natureza ou a busca pela igualdade entre as pessoas; ora por objetivos financeiros, que têm feito emergir, dentre inúmeras outras estratégias do capitalismo, o mercado da sustentabilidade. Nesse contexto, também ocorrem iniciativas de reflexão, análise e mudança, originárias da produção intelectual e artística ou da mobilização social.

Quando tal caminho da precaução decai (fato frequente considerando a ação humana) imperam o imediatismo das necessidades e o caráter contingencial nas intervenções sobre o ambiente. Esses fatores são constantemente justificados por (e para) determinados grupos de pessoas ou servem à satisfação das demandas de tempos específicos, acompanhando contextos sociais e naturais fragmentários. Nesse instante, suprimimos mais a natureza do que a conservamos, uma vez que o "nosso tempo", humano, diverge muito do tempo do restante do ambiente que nos cerca.

Diante disso, é importante elucidar o reconhecimento dos "saberes ambientais" que, por qualquer via que seja, nas pesquisas, nas ações sociais e políticas, ainda que de forma desigual ou, por vezes, penosamente, em catástrofes e riscos vivenciados, têm adentrando o cotidiano. Fortalecer essas ideias faz parte de um processo árduo de convencimento e, perante a dinâmica e efemeridade dos acontecimentos relacionados, deve ser sempre um processo contínuo e crítico.

Levanta-se, nesse sentido, uma preocupação demonstrada por Castells (1983), pela qual a problemática ambiental deve ser considerada, mas não pode se apresentar como uma

\footnotetext{
${ }^{64}$ As breves reflexões apresentadas no Elo Três são resultado do processo de construção teórico-prático da tese defendida pela autora no Programa de Pós-Graduação em Desenvolvimento e Meio Ambiente da UFPE, sendo inseridos, dessa forma, alguns trechos do trabalho.
} 
"cortina de fumaça" na observação da realidade. O autor afirma que os estudos ditos ambientais apresentam uma tendência a agrupar problemas de origens diversas e complexas.

Por vezes, questões cruciais relativas a injustiças sociais ou à desigualdade de acesso a determinadas condições de vida, não recebem a devida consideração, ao serem equiparadas, por exemplo, ao exacerbado crescimento industrial e seus efeitos poluidores, ou então à superpopulação ou efeito estufa, dentre outros elementos que compõem a "questão ambiental". Também lembra que não se deve desconsiderar a existência de danos ao ambiente, mas que a forma de análise deve ser revista, a fim de se chegar aos problemas reais que afetam um determinado território ou espaço (CASTELLS, 1983).

Dessa forma, pode-se refletir que as práticas e a produção do conhecimento em relação ao ambiente são tencionadas por micro ou macro fatores de ordem histórica, cultural, social, econômica ou política; suas consequências são permeadas por interesses que levam à articulação ou invisibilização de atores sociais, que receberão os benefícios ou prejuízos, dependendo de suas possibilidades de interferir nas decisões tomadas.

É o reflexo perverso de uma sociedade que vive em uma rotina de contrassensos e divergências, pela qual interesses políticos determinam o rumo e alcance dos benefícios e danos ambientais, em detrimento de razões técnicas explícitas sobre o meio físico ou as necessidades dos seres vivos em geral. Como elemento de ponderação, evidencia-se que para toda mobilização social ou conhecimento e tecnologias gerados, é urgente atentar para as reais possibilidades de ganhos e danos de forma mais equânime, seja do ponto de vista do acesso, como da distribuição de seus efeitos territorialmente.

Assim, em tempos de naturalização da supressão do meio ambiente (onde por vezes reside a conveniente mitigação), estetização da condição de miséria, indiferença e uma pseudo-solidariedade diante do sofrimento de seres humanos e não humanos, espera-se que a associação dos temas e esforços apresentados nos trabalhos que compõem essa obra, ofereça suporte para a reflexão e, sobretudo, para a transformação de nossos "teimosos" e "preguiçosos” paradigmas.

\section{REFERÊNCIA}

CASTELlS, M. A questão urbana. 3. ed. revisada, acompanhada de um posfácio (1975). Rio de Janeiro: Paz e terra, 1983. 590 p. 


\section{$\cos$}

Esta coletânea reúne resultados de pesquisas, estudos e experiências de docentes, discentes, profissionais e pesquisadores e pesquisadoras das diversas áreas do conhecimento, com linguagem adequada à compreensão dos leitores e das leitoras que desejem se cientificar das atuais discussões no âmbito da temática ambiental. A obra contempla 12 capítulos inter-relacionados com abordagem interdisciplinar.

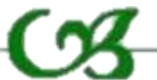

APOIO:
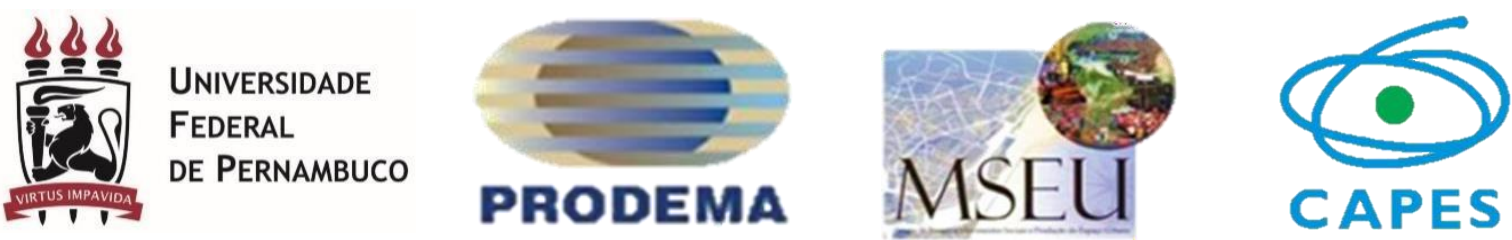


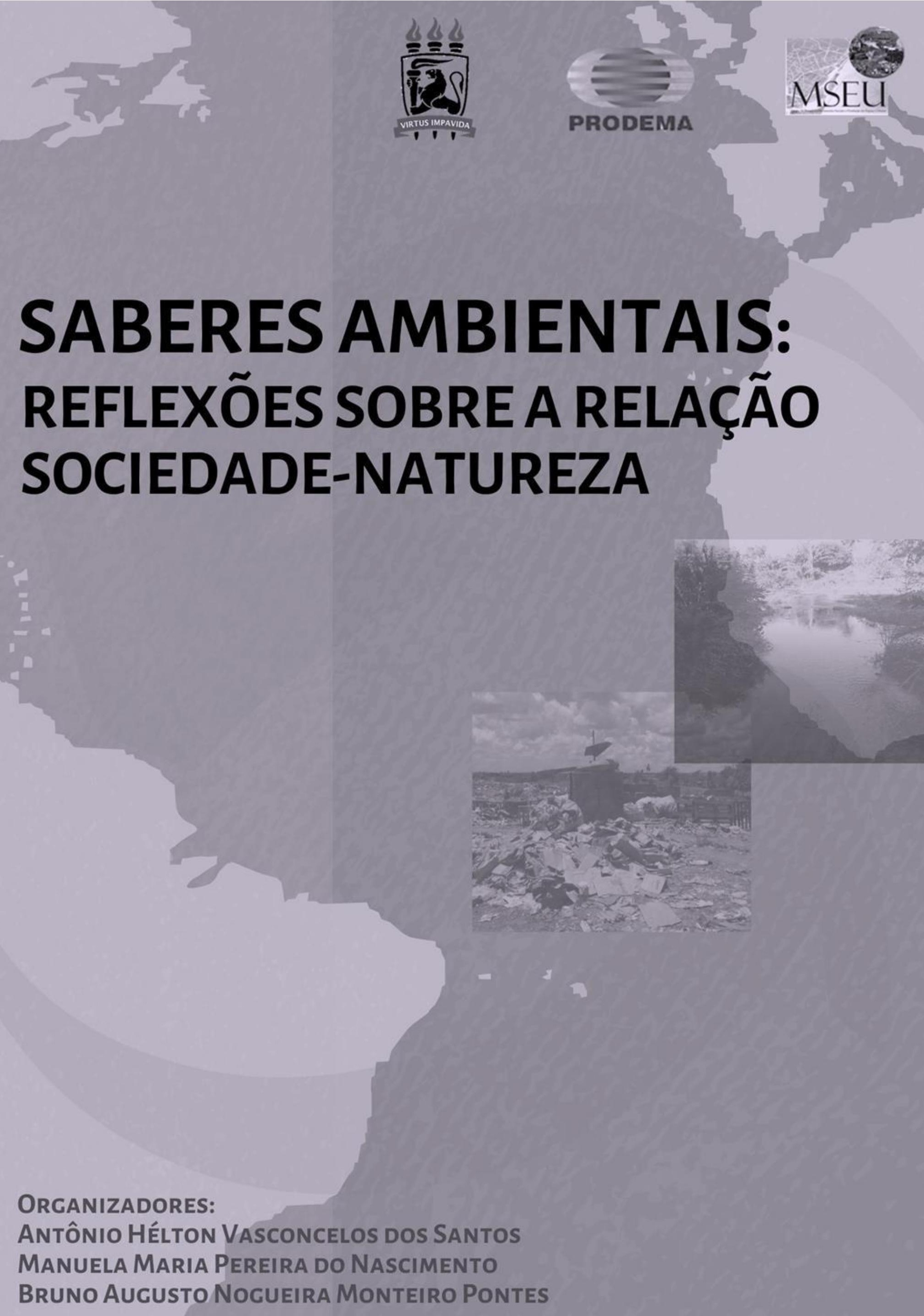

